DOE/CE/27438--1-Vol.1

DE92 016388

\title{
An Analysis of Residential \\ Energy Consumption In A \\ Temperate Climate
}

\author{
by \\ Y.Y. Clark \\ Walter Vincent
}

\author{
June 1987 \\ School of Engineering and Technology \\ Tennessee State University \\ Nashville, Tennessee
}

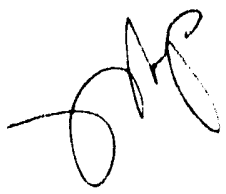




\begin{abstract}
Electrical energy consumption data have been recorded for several hundred submetered residential structures in Middle Tennessee. All houses were constructed with a common "energy package". Specifically, daily cooling usage data have been collected for 130 houses for the 1985 and 1986 cooling seasons, and monthly heating usage data for 186 houses have been recorded by occupant participation over a seven-year period. Cooling data have been analyzed using an SPSSx multiple regression analysis and results are compared to several cooling models. Heating, base, and total energy usage are also analyzed and regression correlation coefficients are determined as a function of several house parameters.
\end{abstract}

\title{
DISCLAIMER
}

This report was prepared as an account of work sponsoret by an agency of the United States Government. Neither the United States Government nor a.ny agency thereof, nor any of their employees, makes any warranty, express or implied or assumes any legal liability or responsibility for the accuracy, completeness, or usefulness of any information, apparatus, product, or process disclosed, or represents that its use would not infringe privately owned rights. Reference herein to any specific commercial product, process, or service by trade name, trademark, manufacturer, or othenvise does not necessarily constitute or imply its endorsement, recommendation, or favoring 'sy the United States Government or any agency thereof. The views and opinions of authers expressed herein do not necessarily state or reflect those of the United States Government or any agency theresf. 


\section{ACKNOWLEDGMENT}

We wish to acknowledge the support and contributions of the two consultants provided for by the Grant: Michael R. Busby, P.E. and Watt Count Engineering, Inc. We also wish to thank Milton Hebert Clark, who assisted in the preparation of this document. 
TABLE OF CONTENTS

PAGE

Abstract . . . . . . . . . . . . . . . . 11

Acknowledgment . . . . . . . . . . . . . . . ili

List of Tables . . . . . . . . . . . . . . . . . vi

List of figures . . . . . . . . . . . . . . . . . vii

Chapter I Introduction . . . . . . . . . . . . 1

Chapter II Engineering Analysis and Construction
Procedures . . . . . 3

Energy Analysis and HVAC Duct
Design . . . . . . 3

Insulation and Infiltration
Specifications . . . . . . 5

Construction Procedures . . . . . . 8

Chapter III Analysis of Heating Energy Usage... . 11

Structure Description and
Data Collection . . . . . . . . 11

Analysis of Energy Consumption
Using Regression Techniques . . . 12

Statistical Framework . . . . . 13

Chapter IV Analysis of Cooling Energy Usage . . . . 29

Structure Description and Data
Collection . . . . . 29

Climatic Parameters . . . . . . 37

Cooling Energy Usage for Various
Time Intervals . . . . . . 48

Cumulative Cooling Energy Usage
for A Cooling Season . . . . 68 
Comparison with Cooling Energy

Usage Models .... . . . . 88

Chapter $V$ Comparison of Present Data with Other

Studies . . . . . . . . . . . 91

Chapter VI Summary of Results . . . . . . . . . . 99

List of References . . . . . . . . . . . . 102

Appendix 1 Energy Usage Data for Submetered
Houses with "Energy Package" . . . . 1-0

Appendix 2 Postcard for Meter Data Reading . . . . 2-0

Appendix 3 National Weather Bureau Heating

Degree-Day Data for Middle Tennessee. 3-0

Appendix 4 Survey Form . . . . . . . . . . . . . 4-0

Appendix 5 Theoretical Heating and Cooling Load
Analyses . . . . . . . . . . . 5-0

Appendix 6 Energy Usage Data of Brentwood Pointe
and Heritage Square for 1985-86. . . Vo1.2

Appendix 7 National Oceanic and Atmospheric

Administration Weather Data for

Nashville, Tennessee 1985-86. . . . 7-0 


\section{LIST OF TABLES}

Table 1 Duct Design Criteria . . . . . . . . . 5

Table 2 HVAC Units for Brentwood Pointe . . . . . 34

Table 3 Correlation of Climatic Parameters with ${ }^{\text {C C . . . } 43}$

Table 4 Cooling Usage of Unit A (\#3928) for Various
Time Intervals and Climatic Parameters . 67

Table 5 Cooling Usage of Unit B (\#4063) for Various 68 Time Intervals and Climatic Parameters • 68

Table 6 Correlation of Structure Cooling Energy Usage with Cumulative Cooling DegreeHours (June 19, 1985 to September 26, 82 1985

Table 7 Correlation of Structure Cooling Energy Usage with Cumulative Cooling Degree-
Hours for 1985 and 1986.0 .82 Cable 8 Cooling Energy Usage vs Cooling Degree:-
Hours for Various House Designs . . . 88

:able 9 Comparison of Heating Energy Usage for Conventionally Built and Controlled Construction Houses . . . . . . . . 91

Tiable 10 Comparison of Cooling Energy Usage for Conventionally Built and Controlled Construction Houses ......... . 98 


\section{LIST OF FIGURES}

Figure 1 Typical HVAC Duct System Design • • • • • • 6

Figure 2 Base Energy Usage per Day vs House Size • 16

Figure 3 Base Energy Usage per Day vs House Size for $95 \%$ Confidence Limits...... . 17

$\begin{aligned} & \text { Figure } 4 \text { Heating Energy Usage per Degree-Day vs } \\ & \text { House Size . . . . . . . . . . . } 20\end{aligned}$

$\begin{array}{rr}\text { Figure } 5 \quad \text { Heating Energy Usage per Degree-Day vs } & \\ & \text { House Size for } 95 \% \text { Confidence Limits }\end{array}$

Figure 6 Total Energy Usage per Day vs House Size. • 23

Figure 7 Total Energy Usage per Day vs House Size 24

Figure $8 \quad$ Base Energy Usage per Day vs Total Energy
Usage per Day. . . . . . . . . . 26

$\begin{array}{rrrr}\text { Figure } 9 & \text { Base Energy Usage per Day vs Total Energy } & \\ & \text { Usage per Day for 95\% Confidence Limits } & 27\end{array}$

Figure 10 Site Plan for Brentwood Pointe Condominiums 30

Figure 11 Unit A, Unit $B$, and Unit C Floor Plans for Brentwood Pointe........... . 31

Figure 12 Site Plan for Heritage Square Subdivision • 35

Figure 13 Floor Plans for Heritage Square Subdivision 36

Figure 14 Cooling Degree-Days vs Cooling Degree-Hours for Four-Day Intervals........ . 40

Figure 15 Outdoor Dry Bulb Temperature vs Time of Day for June 17 and 18,1985 . . . . . . 41

Figure 16 Average Outdoor Dry Bulb Temperature vs Cooling Degree-Hours for Four-Day Intervals • 42

Figure 17 Cooling Degree-Days vs Cooling Degree-Hours for One-Week Intervals . . . . . . . . 44 
Figure 18 Average Outdoor Dry Bulb Temperature vs Cooling Degree-Hours for One-Week Intervals............. . . 45

Figure 19 Cooling Degree-Days vs Cooling Degree Hours for Two-Week Intervals . . . . . . . 46

Figure 20 Average Outdoor Dry Bulb Temperature vs Cooling Degree-Hours for Two-Week Intervals... . . . . . . . . . . 47

Figure 21 Typical Unit A Cooling Usage rs Cooling Degree-Hours for Four-Day Intervals. . 49

Figure 22 Typical Unit A Cooling Usage vs Cooling Degree-Days for Four-Day Intervals . . 50

Figure 23 Typical Unit A Cooling Usage vs Average Outdoor Dry Bulb Temperature for Four-Day Intervals . . . . . . . . 51

Figure 24 Typical Unit A Cooling Usage vs Cooling Degree-Hours for One-Week Intervals. . . 52

Figure 25 Typical Unit A Cooling Usage vs Cooling Degree-Days for One-Week Intervals . . 53

Figure 26 Typical Unit A Cooling Usage vs Average Outdoor Dry Bulb Temperature for One-Week Intervals . . . . . . . . 54

Figure 27 Typical Unit A Cooling Usage vs Cooling Degree-Hours for Two-Week Intervals . . 55

Figure 28 Typical Unit A Cooling Usage vs Cooling Degree-Days for Two-Week Intervals. . 56

Figure 29 Typical Unit A Cooling Usage vs Average Outdoor Dry Bulb Temperature for Two-Week Intervals . . . . . . . . .

Figure 30 Typical Unit B Cooling Usage vs Cooling Degree-Hours for Four-Day . . . . . 58 Intervals

Figure 31 Typical Unit B Cooling Usage vs Cooling Degree-Days for Four-Day Intervals. . . 59 
Figure 32 Typical Unit B Cooling Usage vs Average Outdoor Dry Bulb Temperature for

Four-Day Intervals...... . . . . . 60

Figure 33 Typical Unit B Cooling Usage vs Cooling Degree-Hours for One-Week Intervals. . 61

Figure 34 Typical Unit B Cooling Usage vs Cooling Degree-Days for One-Week Intervals . .

Figure 35 Typical Unit B Cooling Usage vs Average Outdoor Dry Bulb

Temperature for One-Week Intervals . . 63

Figure 36 Typical Unit B Cooling Usage vs Cooling Degree-Hours for Two-Week Intervals.. . 64

Figure 37 Typical Unit B Cooling Usage vs Cooling Degree-Days for Two-Week Intervals •. 65

Figure 38 Typical Unit B Cooling Usage vs Average Outdoor Dry Bulb Temperature for Two-Week Intervals..... . . . . 66

Figure 39 Cumulative Cooling Energy Usage vs Cooling Degree-Hours for Various Individual A Units... . . . . . . . . 69

Figure 40 Cumulative Cooling Energy Usage vs Cooling Degree-Hours for Various Individua 1

B Units . . . . . . . . . 70

Figure 41 Cumulative Cooling Energy Usage vs Cooling Degree-Hours for Various Individual

C Units

Figure 42 Cumulative Cooling Energy Usage vs Cooling Degree-Hours for Various Individual Heritage Square Units... . . . . . 72

Figure 43 Overlay Plot of Cooling Energy Usage vs Cooling Degree-Hours of Unit A (Log \#3928)

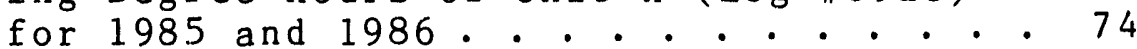

Figure 44 Regression P1ot of Cooling Energy Usage vs Cooling Degree-Hours of Unit A $(\log \# 3928)$. . . . . . . . . . 75 
Figure 45 Overlay Plot of Cooling Energy Usage vs Cooling Degree-Hours of Unit B $(\log \# 2386)$ for 1985 and 1986 ... .476

Figure 46 Regression P1ot of Cooling Energy Usage vs Cooling Degree-Hours of Unit B $(\log \# 2386)$. . . . . . . . . . . . . . . 77

Figure 47 Overlay Plot of Cooling Energy Usage vs Cooling Degree-Hours of Unit C $(\log \# 4052)$ for 1985 and 1986 . . . . . 78

Figure 48 Regression P1ot of Cooling Energy Usage vs Cooling Degree-Hours of Unit C $(\mathrm{Log} \# 4052)$ for 1985 and $1986 . . \cdot$. . 79

Figure 49 Overlay Plot of Cooling Energy Usage vs Cooling Degree-Hours of a Heritage Square House (Log \#423) for 1985

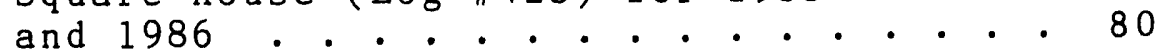

Figure 50 Regression Plot of Cooling Energy Usage vs Cooling Degree-Hours of a Heritage Square House ( Log \#423) for 1985 and 1986

Figure 51 Cumulative Cooling Energy Usage vs Cooling Degree-Hours for A Units . . . 84

Figure 52 Cumulative Cooling Energy Usage vs Cooling Degree-Hours for B Units

Figure 53 Cumulative Cooling Energy Usage vs Cooling Degree-Hours for C Units . . . 86

Figure 54 Cumulative Cooling Energy Usage vs Cooling Degree-Hours for Heritage Square Units . . . . . . . .

Figure 55 Comparison of Utility Company and Present Study Heating Usage Data vs House Size

Figure 56 Expanded Scale Comparison of Utility Company and Present Study Heating Usage Data vs House Size . . . . . . 94 
Figure 57 Cooling Energy Usage vs House Size • • • 95

Figure 58 Comparison of Utility Company and Present Study Cooling Usage Data vs

House Size... . . . . . . . . 96

Figure 59 Expanded Scale Comparison of Utility

Company and Present Study Cooling

Usage Data vs House Size... . . . . 97 


\section{CHAPTER I}

\section{INTRODUCTION}

The disruption of the U.S. economy by the energy crisis of the $1970^{\prime} \mathrm{s}$ seems a distant memory to many in the $1980^{\prime} \mathrm{s}$. Thus, the efforts for energy conservation do not seem to be nearly so necessary today as they were a decade ago. However, in reality, the United States today imports more foreign oil than it did at the time of the Arab oil embargo, and many experts believe that the energy supply outlook is not stable. Even with the temporary passage of the $1970^{\prime} \mathrm{s}$ crisis, energy conservation remains one of the most practical options for ensuring the availability of an adequate energy supply for both the commercial and residential sectors. The concern for the energy future of this country is the basis for this research effort.

This investigation is directed toward an area of significant energy use, i.e. the residential sector. For this study, houses were available in which the construction techniques, thermal envelope insulation measures, and heating and air conditioning systems were documented. A11 houses in the data sets are electrically heated and cooled with heat pump HVAC systems. Each house was submetered so 
that the heating and cooling energy usage could be separated from the base energy usage. The study presents: 1) a HVAC heating usage analysis using statistical regression techniques from a data set of houses ranging from 1000 to 5810 square feet; 2 ) a regression analysis of the total and base energy usage as function of house size, number of occupants, etc. and 3 ) a HVAC cooling usage analysis and model based on experimental submetered energy data taken from two construction sites, one consisting of a condominium development and the other a subdivision of relatively small single family detached homes. This research effort. should provide:

1) A better understanding of the energy use characteristics of residential structures

2) Simple models for heating and cooling energy consumption based on experimental data

3) Comprehensive data sets of submetered energy use from houses with known insulation treatments and HVAC systems 
CHAPTER II

ENGINEERING ANALYSIS AND CONSTRUCTION PROCEDURES

Al1 residential structures studied were instalied with a common "energy package". This package consisted of three parts: 1) an energy analysis and insulation material specification process, 2) quality controlled installation procedures during construction, and 3) a final inspection of the insulation and HVAC systems at the time of cccupancy.

Energy Analysis and HVAC Duct Design

Each house, some built as early as 1978, was analyzed at the "blueprint stage" before construction began. A computer program was then written to calculate the heating and cooling loads based on heat transfer multipliers (HTM) similar to those available ial the ACCA Manua1 J. (1) The HTM's were modified to give a more rcalistic load analysis because the Manual J values greatly over estimated the heating and cooling requirements for structures constructed with this "energy package". However, the Seventh Edition of Manual J published in 1986 (2) presented a more realistic calculation procedure for heating and cooling loads. The agreement between the computer program and Seventh Edition Manual J calculations 
was quite satisfactory. Sample calculations using both methods will be presented in Chapter IV. All houses in this study are located within a 75 mile radius of Nashville, Tennessee. The average number of heating degree-days is 3610 for a base temperature of $65 \mathrm{~F}$. The winter design temperature is taken to be $0 \mathrm{~F}, 14 \mathrm{~F}$ lower than that listed in Manual $\mathrm{J}$, with an indoor dry bulb temperature of $70 \mathrm{~F}$. The lower design temperature was selected in order to be conservative in the load calculations. The summer design temperature is $95 \mathrm{~F}$ with an indoor dry bulb temperature of $75 \mathrm{~F}$.

All structures in this study utilized electric heat pumps which were sized according to the house cooling load. Electric resistance auxiliary heaters were specified for each unit to insure occupant comfort below the house balance point. These heaters were staged in $5 \mathrm{kw}$ to $10 \mathrm{kw}$ increments and controlled on outdoor thermostats to minimize energy consumption during extreme heating conditions. Care was taken to specify heat pumps with reasonably high coefficients of performance ( $C O P^{\prime} s$ ) and energy efficiency ratios (EER's), i.e. $\operatorname{COP}>2.5$ at $47 \mathrm{~F}, \operatorname{COP}>1.5$ at $17 \mathrm{~F}$, and EER $>7.5$. Since the HVAC system cost had to be considered and tailored to the desires of the building contractor or home owner, these efficiency criteria could not always be met.

For each house, great care was taken in the design of the 
HVAC air distribution system. Duct design criteria similar to an "assumed velocity method" (3) were used. Table 1 summarizes the design constraints.

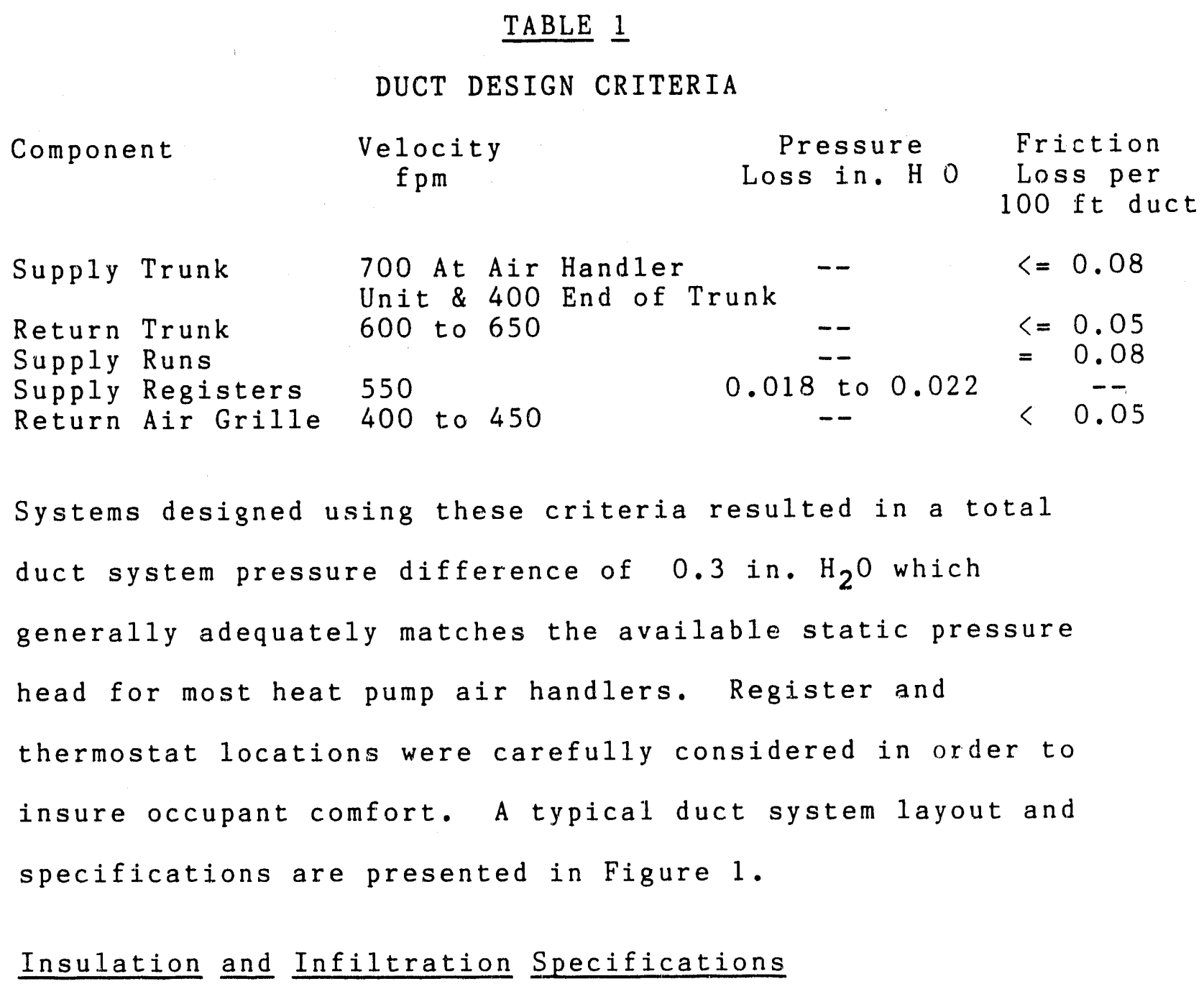

Systems designed using these criteria resulted in a total duct system pressure difference of 0.3 in. $\mathrm{H}_{2} \mathrm{O}$ which generally adequately matches the available static pressure head for most heat pump air handlers. Register and thermostat locations were carefully considered in order to insure occupant comfort. A typical duct system layout and specifications are presented in Figure 1 .

Insulation and Infiltration Specifications

The insulation levels for each house were specified and installed as follows:

Attic insulation: $R-30$ cellulosic fiber or fiberglas Wa11 insulation: R-13 friction fit fiberglas batt 


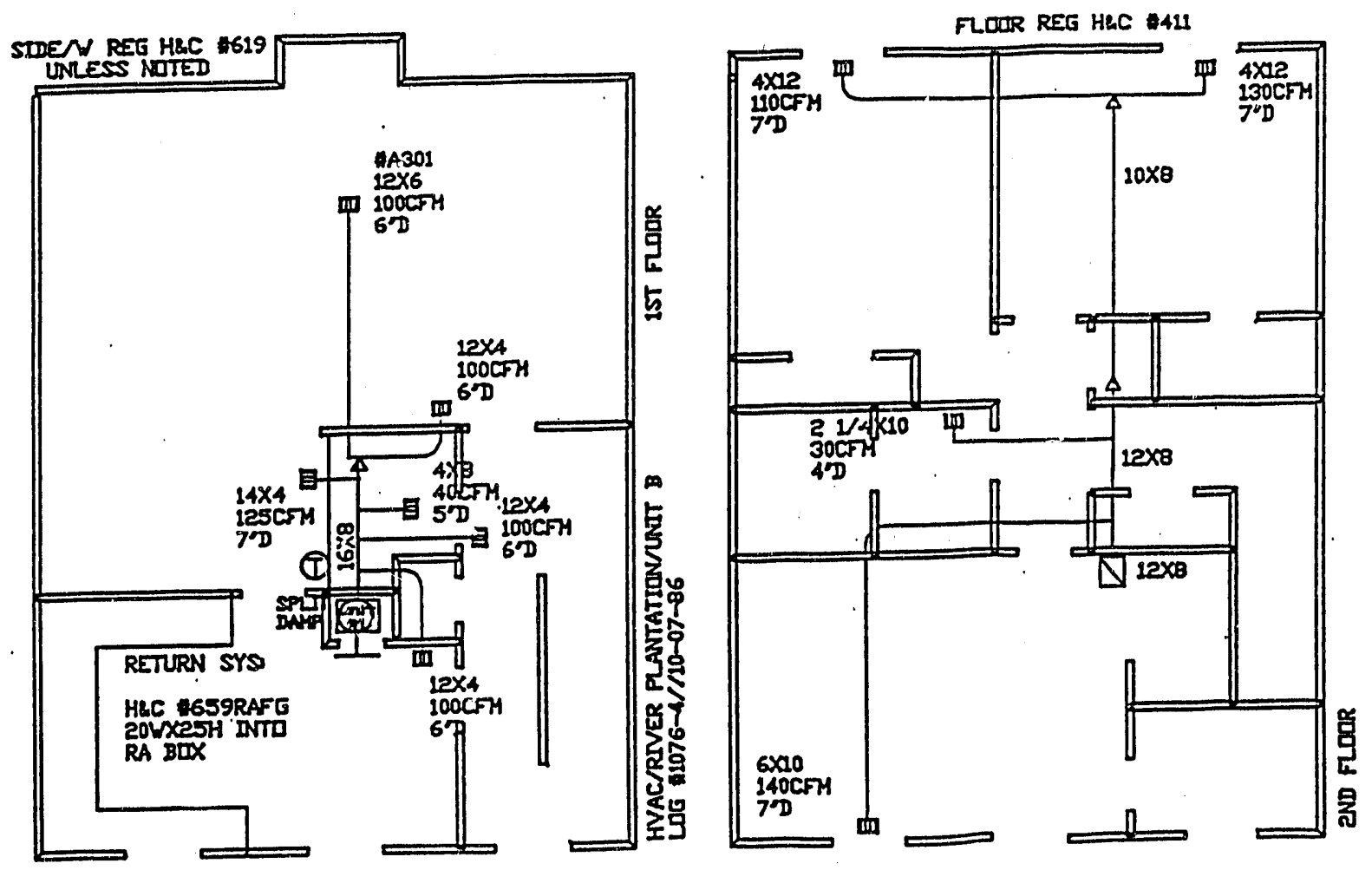

Figure 1 Typical HVAC Duct System Design 
Wall and Ceiling Vapor Barrier: 1 l/2 mil aluminized polyethylene

Wall Sheathing: $1 / 2$ in. impregnated asphalt board

Doors: Metal clad polystyrene core or wood/storm door combination

Windows: Insulated glass or single pane/storm window combination

F1oor: R-11 Kraft back fiberglas batt over unconditioned basements

R-5 foil back duct wrap or $R-5$ extruded polystyrene board on walls of crawl space areas

No perimeter insulation on slab or grade

Ground Cover: Polyethylene (6 mil)

HVAC Duct: For round pipes, R-5 foil backed

fiberglas duct wrap

For rectangular trunk, internal $l^{\prime \prime}$

fiberglas duct liner.

In attic spaces, rectangular truck lined and wrapped.

Infiltration reduction measures:

a) All base plates, top plates, multiple framing members were caulked with a butyl latex material

b) All window and door frames were caulked or sealed

c) All wiring and plumbing penetrations were caulked

d) A11 wall tees and wall corner cavities were insulated with loose fill cellulosic fiber

e) On multiple story houses, the band area between floors was insulated with fiberglas batt insulation 
f) A11 HVAC supply trunk take-offs were caulked and return air duct joints were sealed.

These specifications were considered adequate for the temperate climate in the Nashville Area when initial cost and energy savings were considered.

\section{Construction Procedures}

To insure that the HVAC and insulation systems for each house were installed according to specifications, an on-site inspection program was implemented. Each structure received a minimum of two inspections: 1) At duct system rough-in and wall insulation installation and 2) at the time of occupancy. During the rough-in inspection, al1 wall insulation installation was corrected, if necessary, to insure that gaps, batt compression, etc. were eliminated. Also, the caulking and sealing infiltration measures were inspected for quality and completeness. The HVAC duct distribution rough-in was checked for compliance with the engineering design.

When the rough-in inspection was completed, a $11 / 2 \mathrm{mil}$ aluminized polyethylene vapor barrier was carefully installed on all exterior walls and ceilings. The ceilings of closets, bathrooms, and kitchens were not fitted with the vapor barrier material. These areas were excluded due to the concern for possible liability resulting from excessive 
moisture accumulations due to internal loading from occupant activity.

A comprehensive final inspection was carried out after the home was occupied. At this inspection, the attic insulation, floor insulation, and ground cover installations were checked. The most commonly encountered problems were poorly and unevenly installed attic systems. Drops above showers and soffits were areas sometimes overlooked by the installers. Before the insulation inspection could be passed, the insulation company was required to correct all errors.

The HVAC system received a complete field check-out. Utilizing a Dwyer static pressure gauge, stop watch, velometer, digital thermometer, and the watt-hour submeter, the following measurements were made:
a) Indoor fan power draw in $\mathrm{kw}$
b) Outdoor unit power draw in $\mathrm{kw}$
c) Auxiliary heat staging and power draw in $\mathrm{kw}$
d) Temperature rise and fall across the indoor coil
e) Static pressure at the return and supply air trunks near the unit
f) Velometer cfm measurements at the supply and return registers.

Using the watt-hour submeter, the kw power draw of each electrical component was determined from the following 
equation:

$$
\begin{aligned}
& \text { Power }(\mathrm{kw})=[3.6 * \mathrm{Kh} *(\mathrm{Rev})] /(\mathrm{sec}) \\
& \text { where Power is measured in kilowatts } \\
& \text { Kh is watt-hour meter constant } \\
& \text { Rev is the number of revolutions the watt } \\
& \text { hour disk makes in a given number of } \\
& \text { seconds ( } \mathrm{sec} \text { ) } \\
& 3.6 \text { is a unit conversion constant. }
\end{aligned}
$$

These field readings were checked against the equipment manufacturer's specifications for compliance. The most common problems found in the HVAC systems were:
a) Auxiliary heat not staged properly due to failure of the HVAC contractor to install outdoor thermostats.
b) Low refrigerant charge due to line fitting leakage.
c) Defrost cycle operation failures.
d) Poorly balanced air flow.
e) Compressor failure.

The final HVAC inspection process generally

revealed any of these problems. Upon áscovery, the HVAC contractor was informed, and the appropriate repairs initiated

When all corrections were made to the insulation and HVAC systems, the data collection process began. Houses built using this procedure, i.e. engineering design before construction and an inspection process during building, produced residences that have energy use characteristics generally well below that of homes conventionally constructed. 


\section{ANALYSIS OF HEATING ENERGY USE}

The heating energy consumption analysis utilized the TSU SPSSx Information Analysis System to perform multiple regression analyses on appropriate variables. Energy usage was correlated with house size and occupant characteristics.

\section{Structure Description and Data Collection}

The energy usage data base for 186 homes varying in size from $1000 \mathrm{sq}$. ft. to $5810 \mathrm{sq}$. ft. was generated by occupant participation over a seven year period. The average house size is $1922 \mathrm{sq}$. ft. Appendix 1 presents the raw field data. Each house is identified by log number, Julian date, submeter reading, total house meter reading, square footage and calendar date. The homeowner recorded the energy data on a meter postcard (Appendix 2) and sent the data periodically to the data collection center.

In part of the regression analysis, heating degree-day data were required. Energy use data were available for many houses spanning several winter periods. Thus, when degreeday analyses were undertaken, the data base was expanded from 186 points to 312 . The heating degree-day data for Middle Tennessee for a base temperature of $65 \mathrm{~F}$ was furnished 
by the National Weather Bureau and is presented in Appendix 3 over the time period for which the energy data were collected.

In order to determine other appropriate regression variables, an energy survey form was developed and interviews were conducted with as many home occupants as possible. Family size, ages, and life-style questions were posed and the data tabulated. A sample survey form is given in Appendix 4. The successful number of surveys was 131.

ANALYSIS OF ENERGY CONSUMPTION USING REGRESSION TECHNIQUES

In order to analyze the energy usage data for houses of varying design and size, a regression analysis approach was utilized. Both simple and multiple regression techniques were investigated. Probabilistic models were formulated in order to determine relationships among variables related to energy usage (4). The SPSSx Information Analysis System was used on the DEC VAX $11 / 780$ VMS V4.4 computer system. The computer facilities and the SPSSx programs were invaluable in handling, analyzing, and presenting the collected data in a comprehensible manner.

The energy use data were examined in three areas: 1) base usage, 2) HVAC usage, and 3) total energy usage. These data were determined on a usage per day or degree-day basis. 
and examined as a function of house size (square footage), number of occupants, thermostat setting, and number of stories. Using regression analysis techniques, expressions for the mean values of base, HVAC, and total energy usage in a $95 \%$ confidence interval are presented.

\section{Statistical Framework}

Let $y$ be the dependent variable to be modeled, and let $x$ be the independent or predictor variable for the response y An SPSSx simple regression analysis will determine the least squares prediction equation for $x$ and $y$ as follows:

$$
\begin{aligned}
\hat{y}= & \hat{\beta}_{0}+\hat{\beta}_{1} x \\
\text { where } \hat{y} & =\text { estimated value of } y \\
\hat{\beta}_{1} & =S S \times y / S S x x \\
\hat{\beta}_{0} & =\bar{y}-\hat{\beta}_{1} \bar{x}
\end{aligned}
$$

and

$$
\begin{aligned}
\text { SSxy } & =\sum_{i=1}^{n} x_{i} y_{i}-\left(\sum_{i=1}^{n} x_{i} \sum_{i=1}^{n} y_{i}\right) / n \\
S S x x & =\sum_{i=1}^{n} x_{i}{ }^{2}-\left(\sum_{i=1}^{n} x_{i}\right)^{2} / n
\end{aligned}
$$

where $n$ = number of pairs of observation of $x$ and $y$.

This analysis minimizes SSE (sum of the squares of errors in y), i.e.,

$$
\operatorname{SSE}=\sum_{i=1}^{n}\left(y_{i}-\hat{y}\right)^{2}
$$

For multiple regression models the calculational procedures are identical although more complex than the simple regression formulations, and the prediction equation is: 


$$
\hat{y}=\hat{\beta}_{0}+\hat{\beta}_{1} x_{1}+\cdots+\hat{\beta}_{k} x_{k}
$$

which minimizes

$$
\operatorname{SSE}=\sum_{i=1}^{n}\left(y_{i}-\hat{y}\right)^{2}
$$

For the present analysis, it is desired to determine the mean value of $y$ at a fixed value of $x$ for a desired confidence interval. Using the student's t-test, the expression for a mean value of $y$ is

$$
\begin{aligned}
& y=\hat{y}+t_{\alpha / 2, n-2} S\left[1 / n+(x-\bar{x})^{2} /(S S x x)\right]^{\frac{1}{2}} \\
& \text { where } t_{\alpha / 2, n-2} \text { is the critical value of } t \\
& S=\text { standard error } \\
& \bar{x}=\sum_{i} x_{1} / n
\end{aligned}
$$

The statistical model adequacy is tested by utilizing the coefficient of correlation for both the simple and multiple regression analysis. The coefficient of correlation, $R$, is defined as follows:

$$
R=\operatorname{SSxy} /(\operatorname{SS} x \mathrm{xS} y \mathrm{y})^{\frac{1}{2}}
$$

where SSxy and SSxx have been previously defined and

$$
\text { SSyy }=\sum_{i=1}^{n} y_{i}{ }^{2}-\left[\sum_{i=1}^{n} y_{i}\right]^{2} / n
$$

A value of $R$ near or equal to zero implies little or no relationship between $x$ and $y$; whereas if values of $R$ are near +1 , a strong relationship is implied.

Base Energy Use Per Day

The annual base energy usage is the sum of the energy 
used to heat domestic water, cook, illuminate the structure, activate appliances, refrigerators, televisions, radios, etc. Since data from the occupant surveys were utilized, there were 131 data points available. The base usage was calculated from the raw data by subtracting the submeter energy use from the total usage and then dividing by the total number of days between readings. In many cases the average base usage was determined over two or even three year periods.

The SPSSx system was employed initially to perform a single regression analysis using the base energy usage per day (BD) as the dependent variable and house square footage (SQ) as the independent variable. The scatter plot is shown in Figure 2. The functional relationship based on a simple regression model is

$$
\hat{B D}=13.0+9.326 \mathrm{SQ}
$$

where $\hat{B D}=$ estimated value of BASE KWH/DAY

$$
S Q=\begin{gathered}
\text { house square footage in } 1000 \text { 's of } \\
\text { square feet }
\end{gathered}
$$

$$
B D=\hat{B D}+1.83\left[0.769+1.356(S Q-1.988)^{2}\right]^{\frac{1}{2}}
$$

where SQ is expressed in 1000's of square feet. A $95 \%$ confidence band for the mean values of $B D$ is plotted in Figure 3. As expected the base usage per day increases with house square footage.

It seems reasonable that the base usage should also be a 


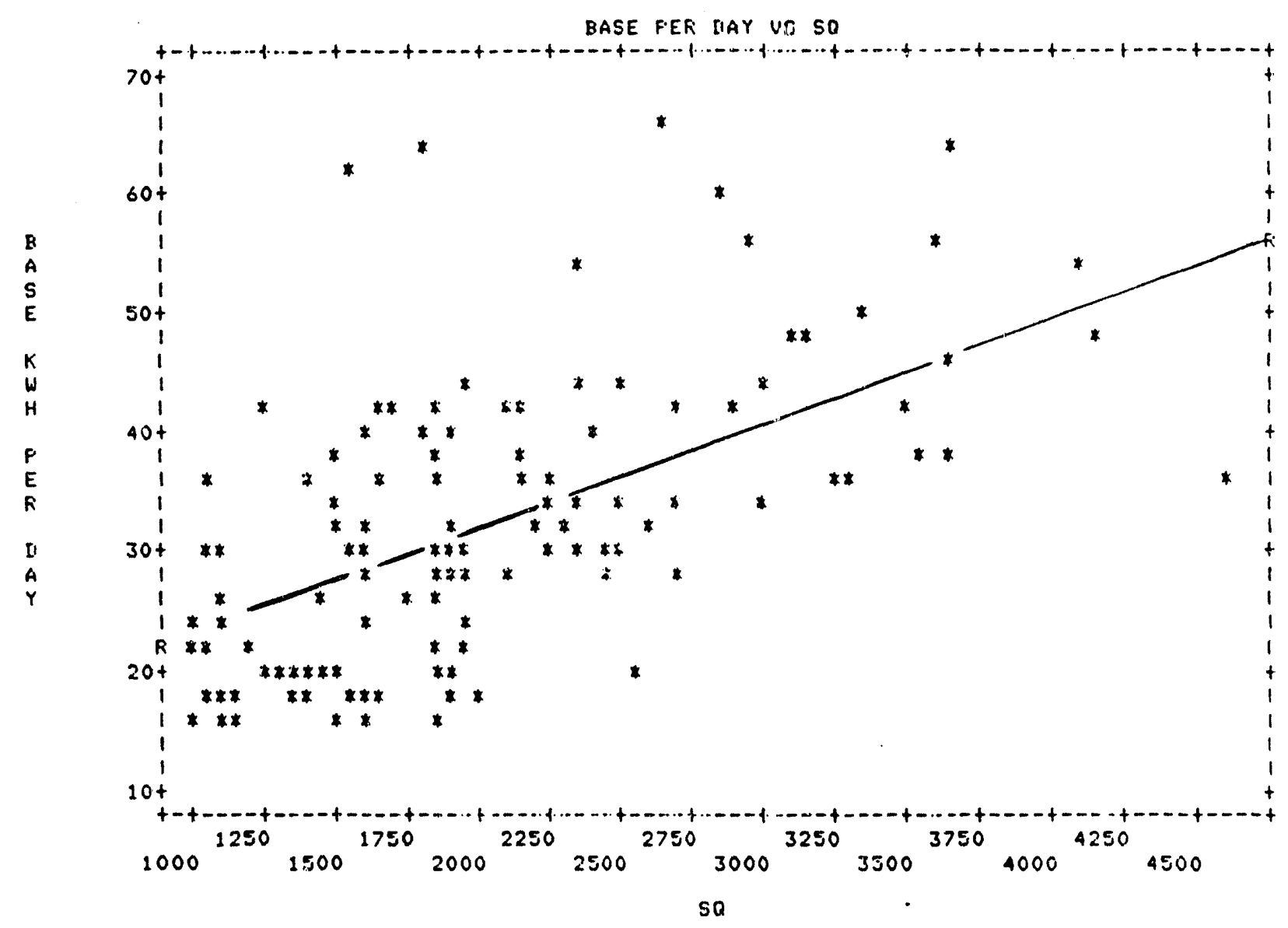

Figure 2 Base Energy Usage per Day vs House Size 
BASE KWH FER IIAY - $95 \%$ CONFI IIENCE EIINII

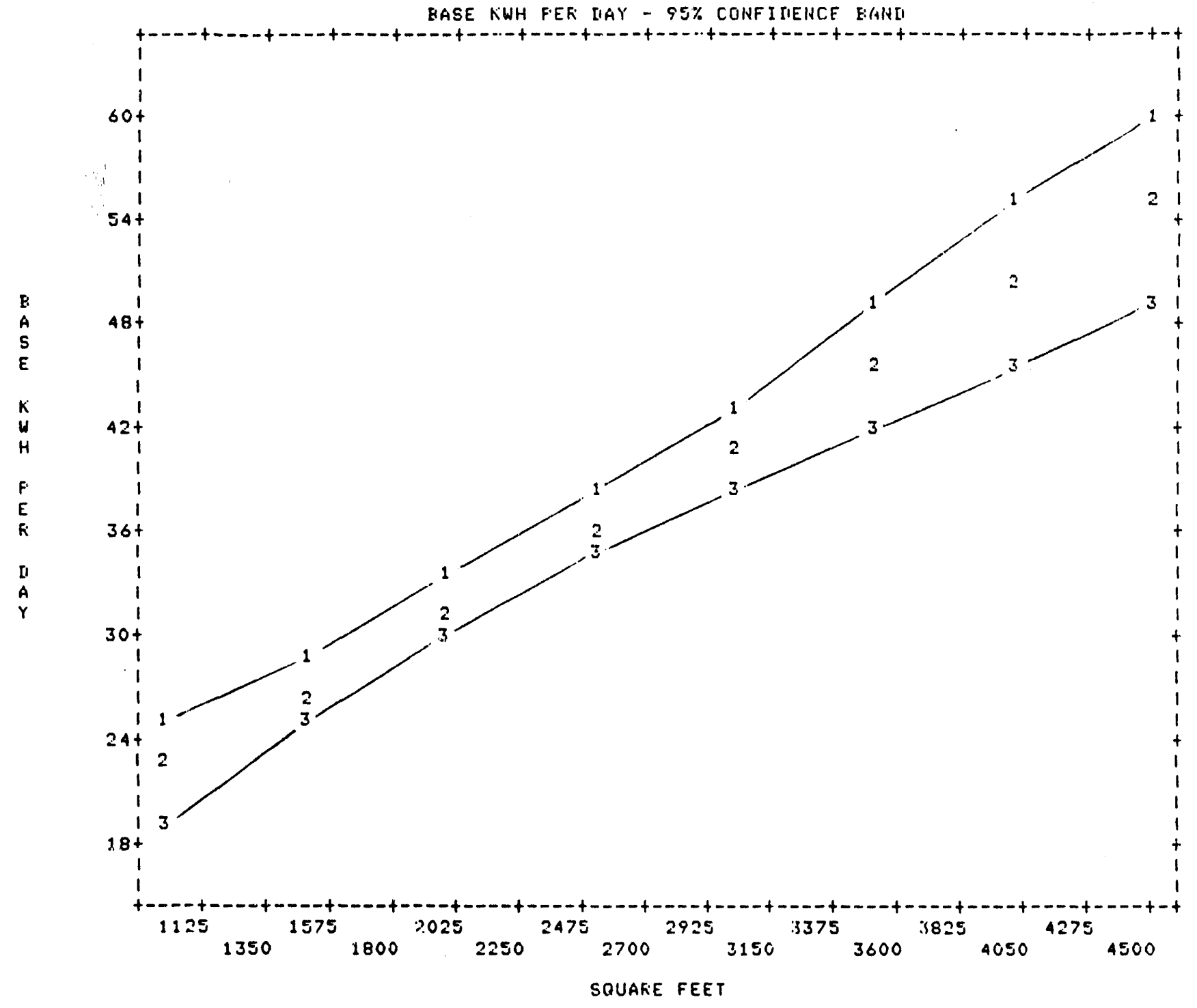

Figure 3 Base Energy Usage per Day vs House Size for 957 Confidence Limits 
function of the number of occupants (NOP) in the house. A multiple regression analysis was performed using $B D$ as the dependent variable and $S Q$ and NOP as the independent regression variables. The SPSSx system determined the following relationship:

$$
\hat{B D}=8.965+4.79 \mathrm{SQ}+4.859 \mathrm{NOP}
$$

The standard error is now 7.82 , and the correlation coefficient increased from 0.6022 to 0.7465

HVAC Heating Energy Use Per Degree Day

The energy used for space heating was investigated with 312 cases available. The raw data were collected from the submeters insta.led on the study houses. The heating data for all houses fell between October 1 and March 31 of consecutive years. The dependent variable selected for heating was HVAC KWH usage per degree day (HVACDD), and the independent variable was house size in $1000^{\prime}$ s of square feet (SQ). A simple regression analysis was performed utilizing SPSSx and the following results were obtained:

$$
\begin{aligned}
& \widehat{\mathrm{HVACDD}}=0.656+0.6905 \mathrm{SQ} \\
& \text { where } \overparen{\text { HVACDD }} \text { = estimated value of heating } \\
& \text { energy used per degree day } \\
& S Q=\text { house square footage in } 1000^{\prime} \mathrm{s} \text { of } \\
& \text { square feet }
\end{aligned}
$$

The standard error is 0.643 and the correlation coefficient 
is 0.6440. The scatter plot is shown in Figure 4. For a $95 \%$ confidence interval, the mean value of HVACDD can be expressed as

$$
\mathrm{HVACDD}=\widehat{\mathrm{HVACDD}}+0.126\left[0.321+0.524(\mathrm{SQ}-1.933)^{2}\right]^{\frac{1}{2}}
$$

where SQ is expressed in 1000's of square feet.

a $95 \%$ confidence level band for the mean values of HVACDD is shown in Figure 5.

A multiple regression analysis was also performed to examine the relationship of HVACDD to a quadratic function of SQ. The SPSSx result is:

$$
\widehat{\mathrm{HVACDD}}=0.126+1.174 \mathrm{SQ}-0.093(\mathrm{SQ})^{2}
$$

with a correlation colfficient of 0.6554. The addition of a term including $\mathrm{SQ}^{2}$ did not significantly improve the data fit.

Several multiple regression analyses were also performed using number of house stories and thermostat setting as independent variables in addition to house size. These analyses did not improve the correlation. Obviously, thermostat settings were not recorded or monitored by research personnel. Thermostat data were obtained from the energy survey form in which the occupants were asked to estimate the settings for winter and summer. It is believed that these estimates are erroneous, and in order to obtain reliable data a thermostat monitoring program should be 
HUACHII US SQ

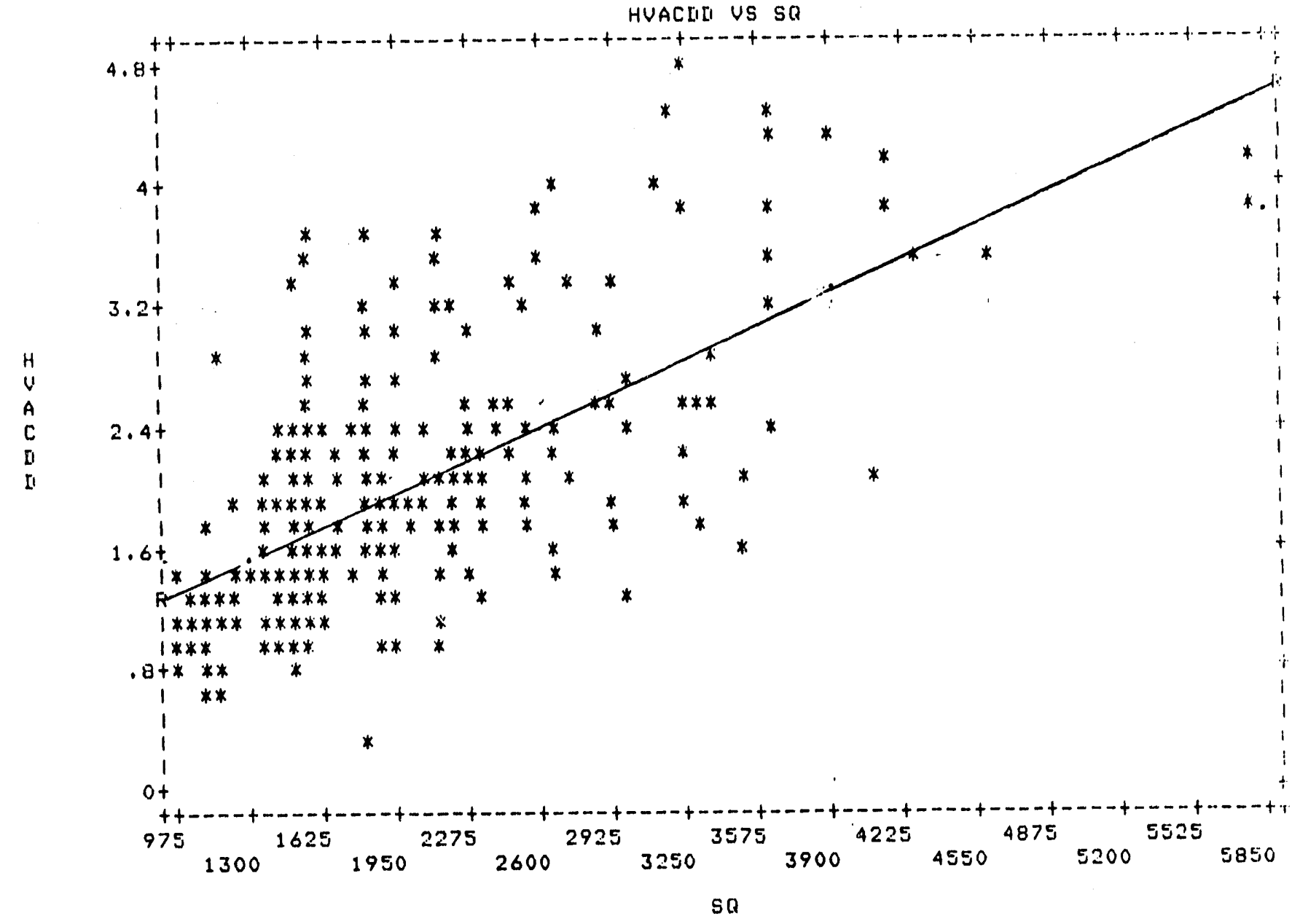

Figure 4 Heating Energy Usage per Degree-Day vs

House Size 


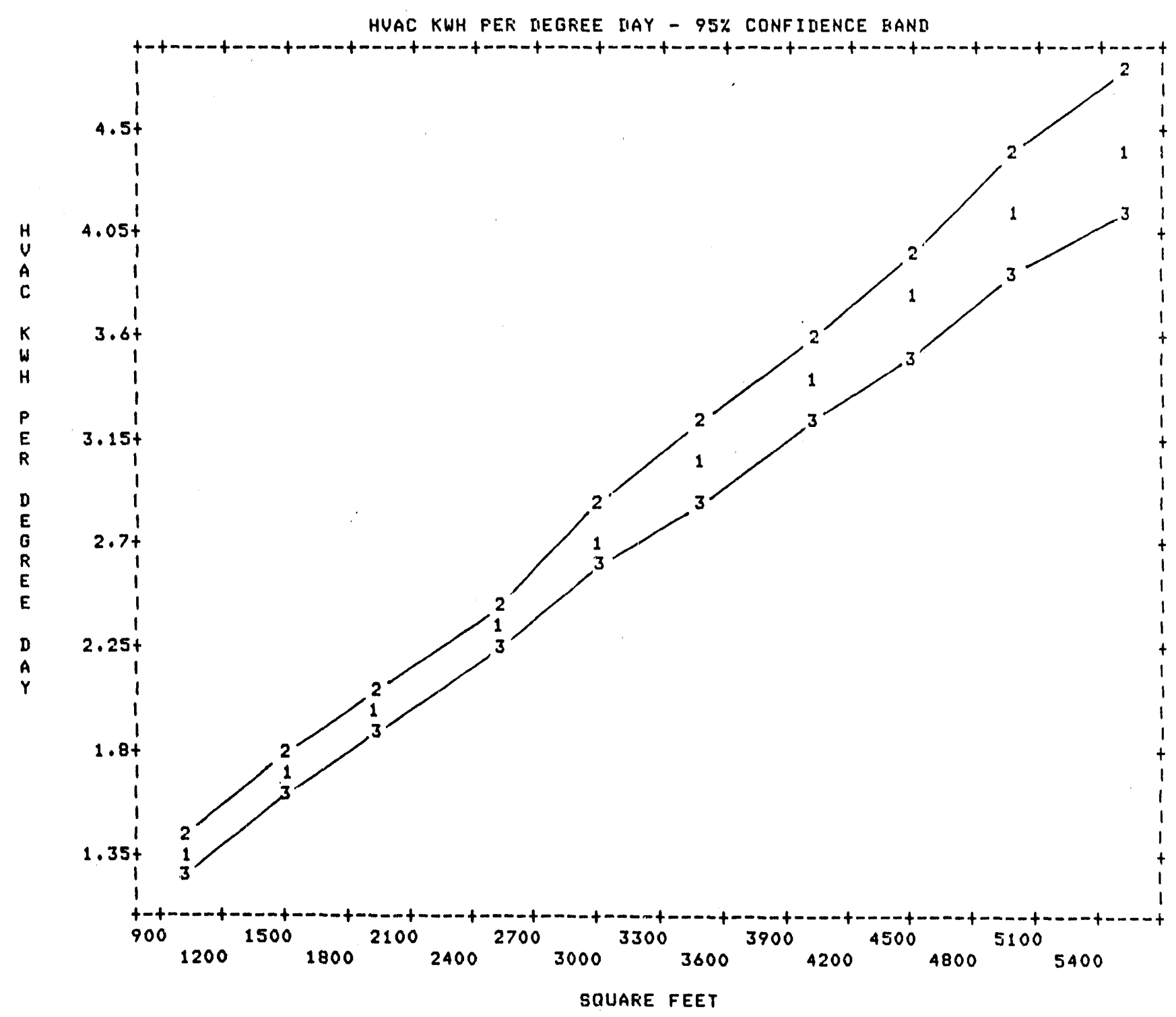

Figure 5 Heating Energy Usage per Degree-Day vs House Size for $95 \%$ Confidence Limits 
established.

\section{Total Energy Usage Per Day}

The raw data obtained from the utility company watthour meter was used to study the total energy usage on a per day basis. The total usage, of course, is the sum of the base and HVAC usage. Both simple and multiple regression analyses were performed. When total KWH usage per day (TKWD) is the dependent variable, and house size (SQ) is the independent variable, the result of the simpl: regression analysis is:

$$
\begin{aligned}
& \text { TKWD }=25.43+18.6 \mathrm{SQ} \\
& \text { where } \mathrm{SQ} \text { is the house square footage in } 1000^{\prime} \mathrm{s} \\
& \text { of square feet and } \\
& \widehat{T K W D} \text { is the estimated value of the total } \\
& \text { energy usage in KWH per day. }
\end{aligned}
$$

The standard error is 13.79 and the correlation coefficient is 0.7003. The scatter plot is shown in Figure 6.

For a $95 \%$ confidence interval, the mean value of TKWD can be expressed as

$$
\mathrm{TKWD}=\widehat{\mathrm{TKWD}}+2.69\left[0.538+1.03(\mathrm{SQ}-1.922)^{2}\right]^{\frac{1}{2}}
$$

where SQ is expressed in $1000^{\prime}$ s of square feet.

For this analysis, 186 cases were available for study. A $95 \%$ confidence level band for the mean values of TKWD is shown in Filure 7 as a function of SQ. 


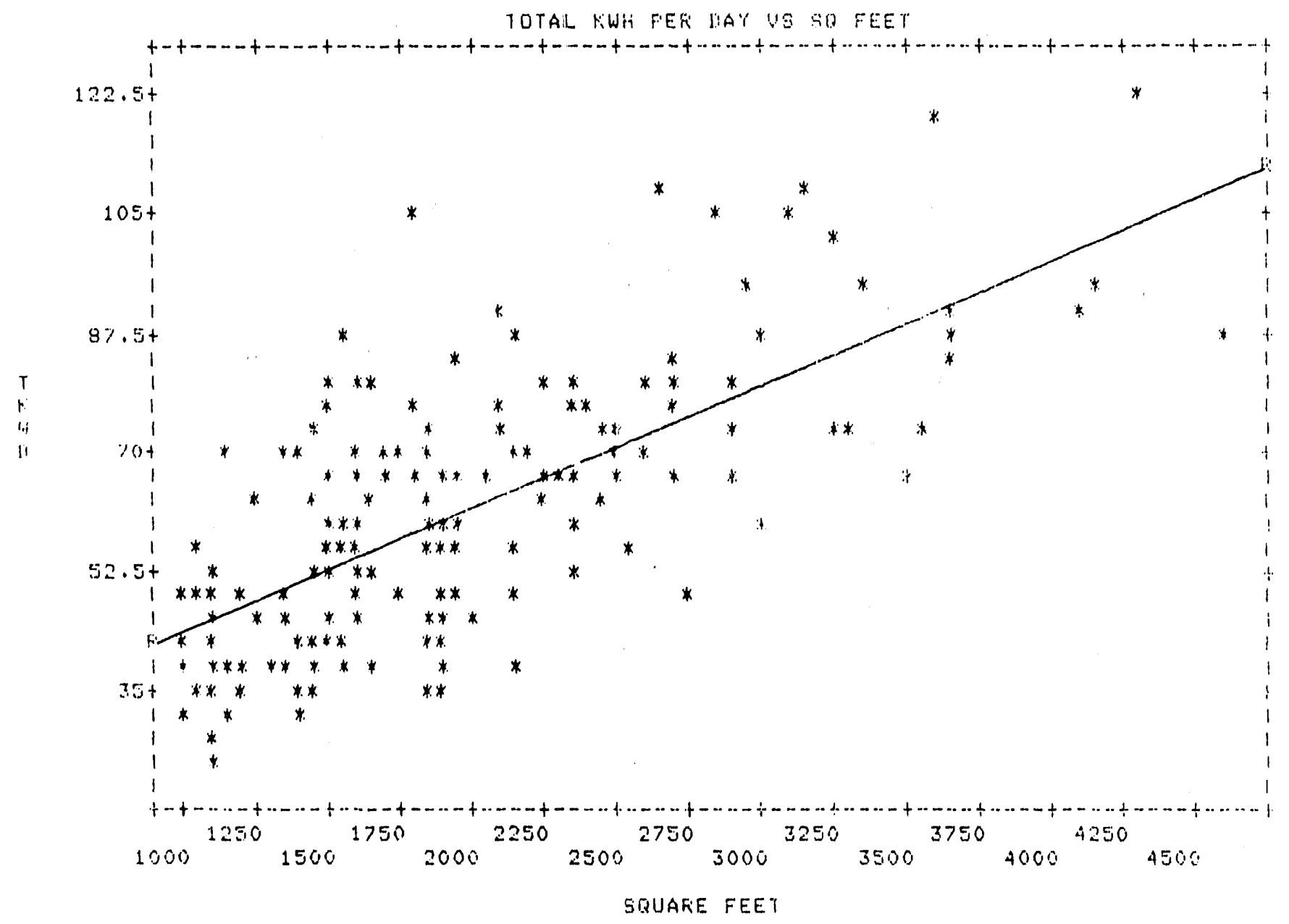

Figure 6 Total Energy Usage per Day vs House Size 


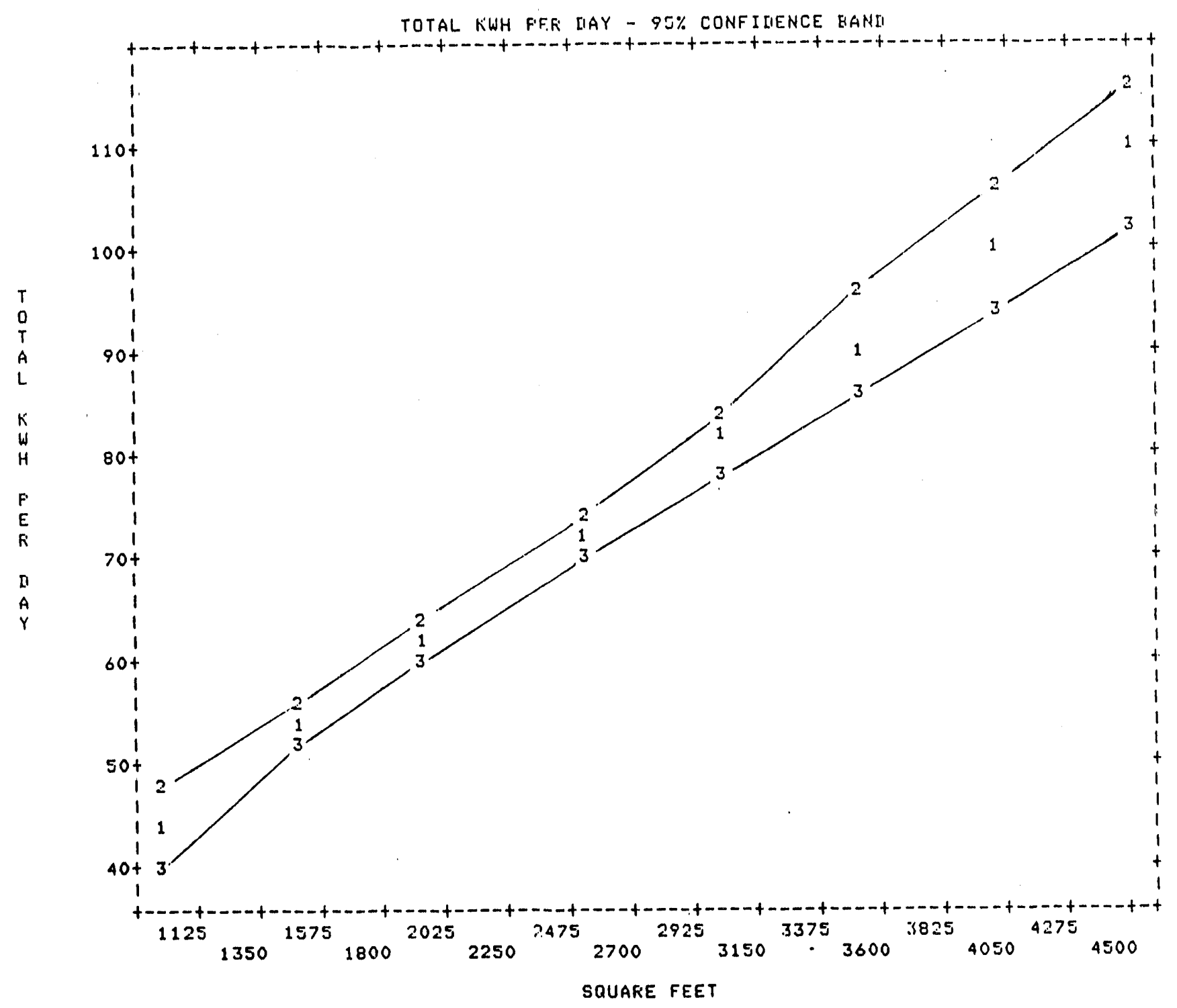

Figure 7 Total Energy Usage per Day vs House Size for $95 \%$ Confidence Limits 
A multiple regression analysis was performed using TKWD as the dependent variable and $S Q$ and NOP as the independent regression variables. The SPSSx program generated the following relationship:

$$
\widehat{\mathrm{TKWD}}=18.55+14.48 \mathrm{SQ}+5.25 \mathrm{NOP} \text {. }
$$

The standard error is now 12.67 and the correlation coefficient increased to 0.7791 .

Base KWH Usage As A Function Of Total Energy Usage An interesting relationship was obtained when a simple regression analysis was performed for base energy use as a function of the total energy use on a per day basis. For this analysis, 186 cases were available. The SPSSx program calculated the following relationship:

$$
\widehat{B D}=0.632+0.5105 \mathrm{TKWD} \text {. }
$$

The standard error is 6.134 and the correlation coefficient is 0.8492 . The scatter plot is presented in Figure 8. A $95 \%$ confidence level band for the mean values of $B D$ is shown in Figure 9 as a function of TKWD. The expression for the $95 \%$ confidence level is given by

$$
\mathrm{BD}=\widehat{\mathrm{BD}}+1.20\left[0.5376+1.456 * 10^{-3}(\mathrm{TKWD}-61.23)^{2}\right]^{\frac{3}{2}}
$$

This comparison of base energy usage to total usage reveals that approximately $50 \%$ of the total energy is utilized in lifestyle related functions. In the Middle Tennessee area, the Tennessee Valley Authority and local utilities have 


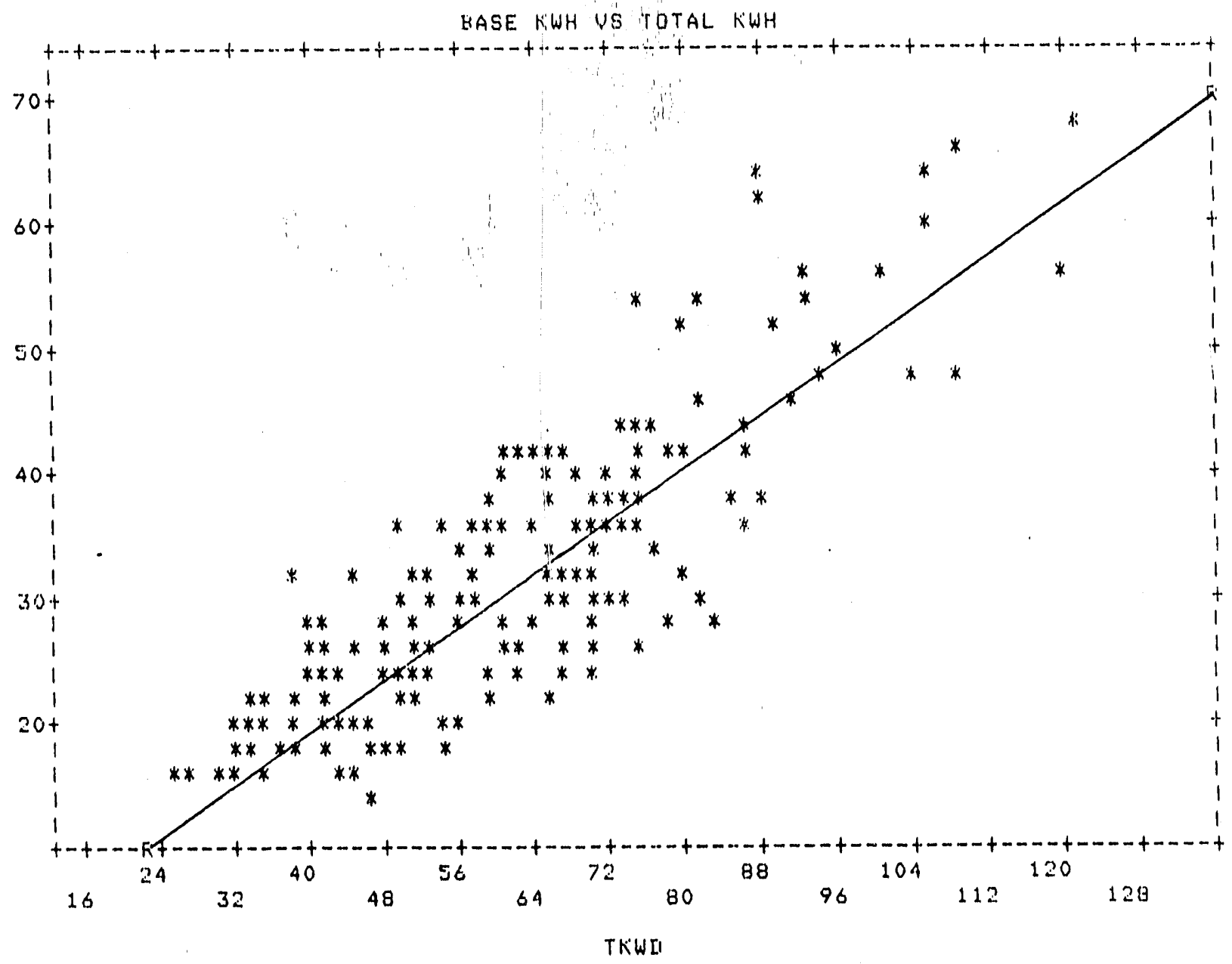

Figure 8 Base Energy Usage per Day vs Total Energy Usage per Day 


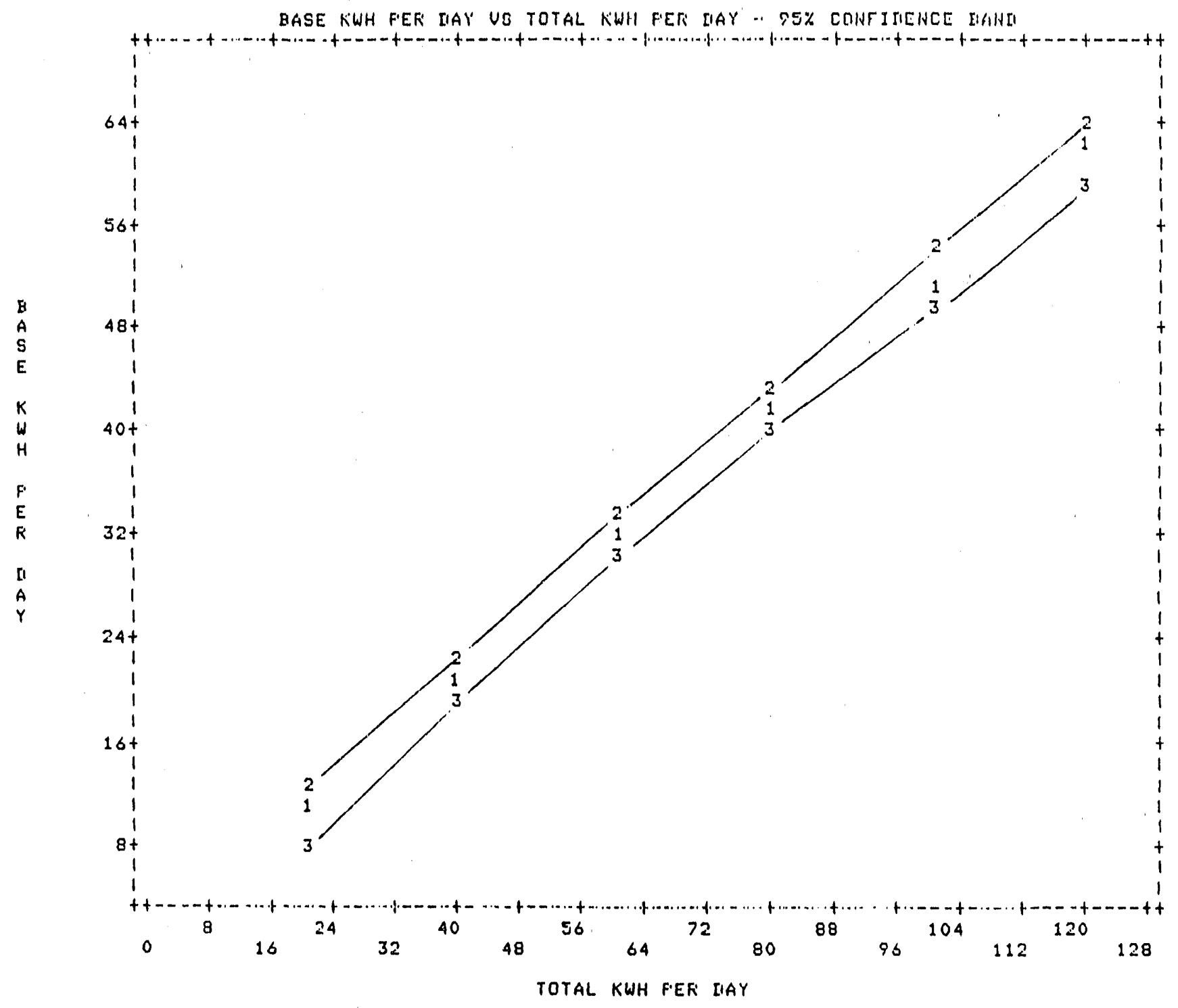

Figure 9 Base Energy Usage per Day vs Total Energy Usage per Day for $95 \%$ Confidence Limits 
estimated the background usage accounts for on 1 y 30 to $35 \%$ of the total usage. The higher percentage obtained in this study may possibly be accounted for by the careful attention to details during construction, thereby, reducing the space heating and cooling requirements. 
CHAPTER IV

ANALYSIS OF COOLING ENERGY USAGE

The cooling energy consumption analysis consists of two parts: 1) correlation of individual house energy data with climate indicators, e.g. cooling degree-hours, cooling degree-days, or average outdoor temperature and 2) the prediction of cooling energy usage from theoretical models.

Structure Description and Data Collection

The primary cooling data set was generated from two locations in the Nashville area, i.e. Brentwood Pointe Condominiums and Heritage Square subdivision. The Brentwood Pointe development is a slab on grade construction of quadruplex buildings. The development site plan is presented in Figure 10. There are three floor plans, i.e. A, $B$, and $C$ which have been built and are shown in Figure 11 . For this study data from 23 A units, 31 B units, and $49 \mathrm{C}$ units are included in the analysis. These units are fitted with Carrier 38 CQ Model heat pumps as presented in Table 2 . The theoretical heating and cooling load analyses are presented in Appendix 5. The computer generated loads and those manually calculated using Manual J, Seventh Edition are given. The agreement between the two methods is 


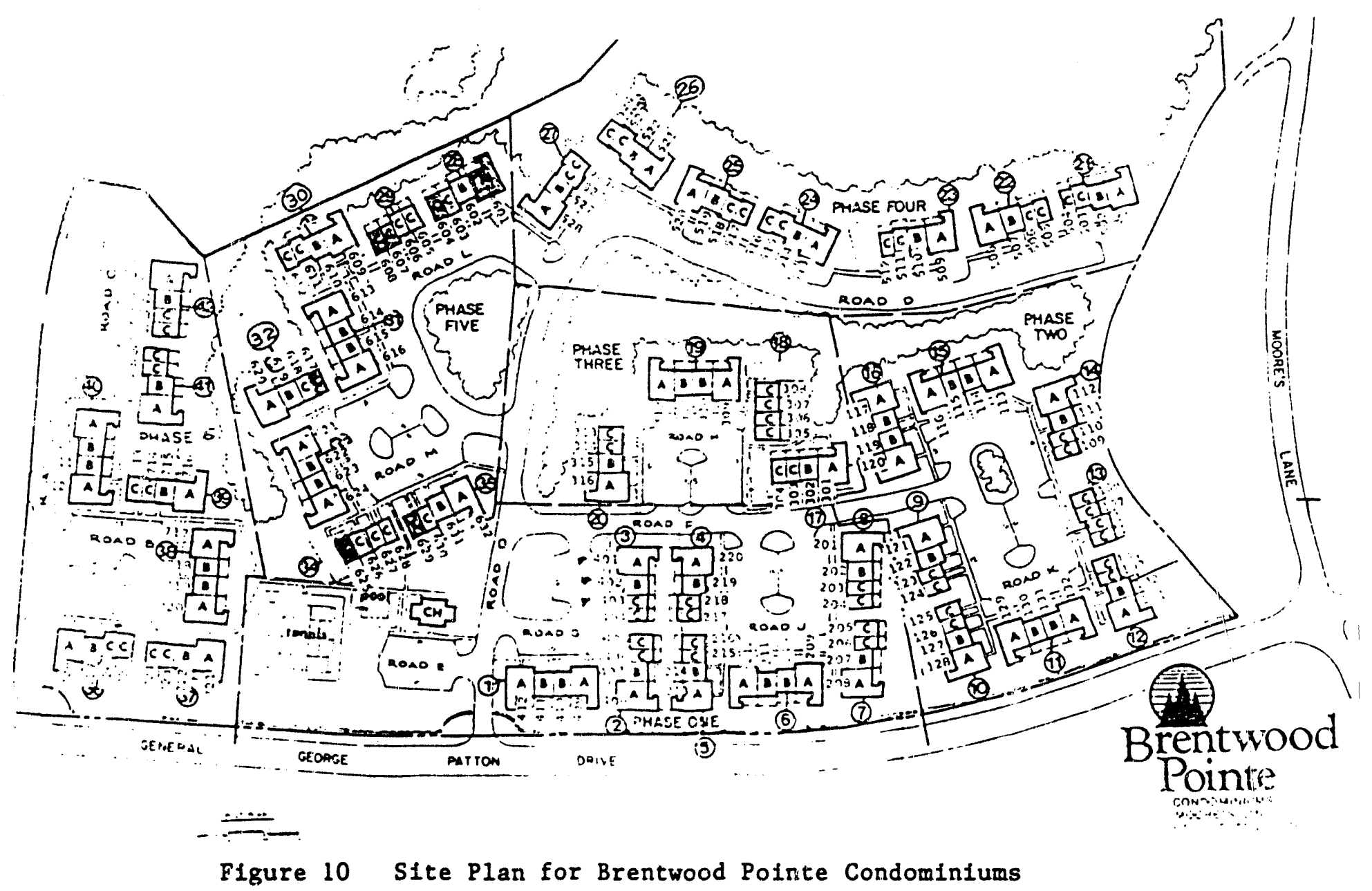




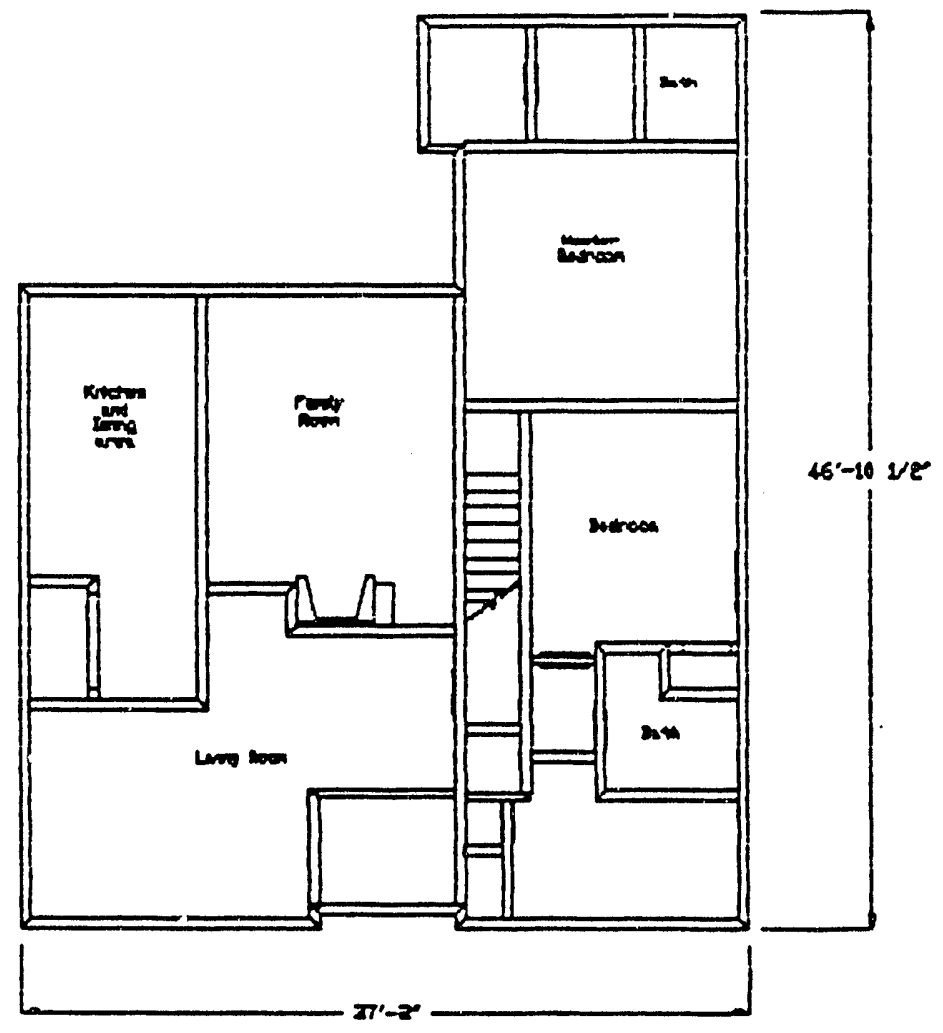

Figure 11 Unit A, Unit $B$, and Unit C Floor Plans for Brentwood Pointe 

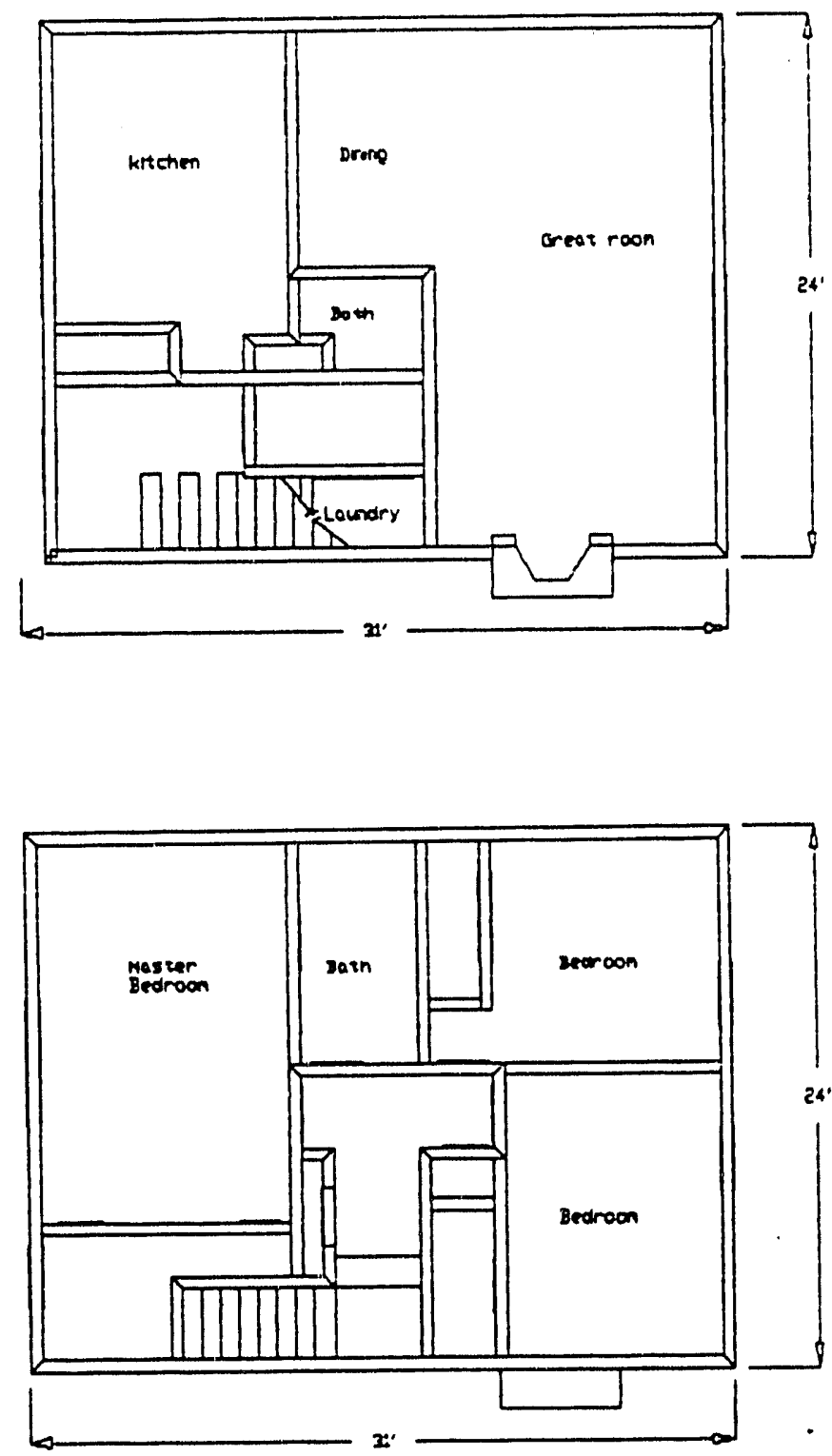

Figure 11 Unit A, Unit B, and Unit C Floor Plans for Brentwood Pointe 

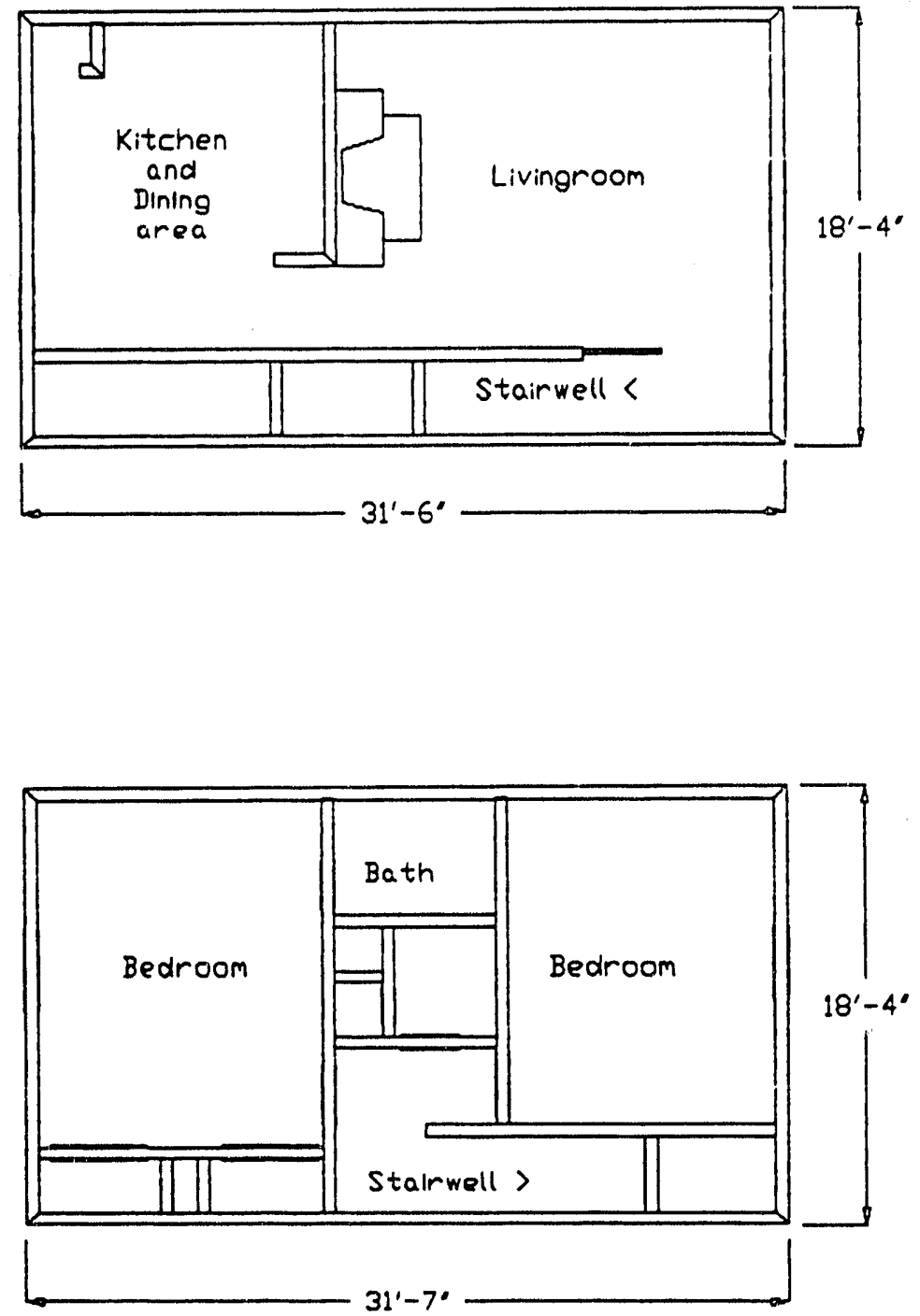

Figure 11 Unit $A$, Unit $B$, and Unit $C$ Floor Plans for Brentwood Pointe 
satisfactory.

$\underline{T A B L E} \underline{2}$

HVAC UNITS FOR BRENTWOOD POINTE

$\begin{array}{cccccc}\begin{array}{c}\text { Condo } \\ \text { Unit }\end{array} & \begin{array}{c}\text { Outdoor } \\ \text { Unit }\end{array} & \begin{array}{c}\text { Indoor } \\ \text { Unit }\end{array} & \text { EER } & \begin{array}{l}\text { COP } \\ 47 \mathrm{~F}\end{array} & \begin{array}{l}\text { COP } \\ 17 \mathrm{~F}\end{array} \\ \text { A } & 38 \mathrm{CQ027} & 40 \mathrm{AQ030} & 6.4 & 2.4 & 1.5 \\ \text { B, C } & 38 \text { CQ020 } & 40 \mathrm{AQ024} & 7.2 & 2.9 & 1.7\end{array}$

The Heritage Square Subdivision is a development of single family detached houses of similar square footage. A site plan is presented in Figure 12. The three different floor plans are presented in Figure 13. Data from twentyseven (27) controlled construction houses were taken. Adjacent to the Heritage Square development is another subdivision of similar homes but constructed in a conventional manner, i.e. no particular attention to energy details was given during construction. Ten of these homes were submetered and cooling data were also taken. Also, total energy usage from the utility company watt-hour meter was recorded for 26 conventionally built homes in the same subdivision. The Heritage development was completed in 1978 whereas Brentwood Pointe was built in $1984-85$.

Data for the cooling energy usage study were taken by 


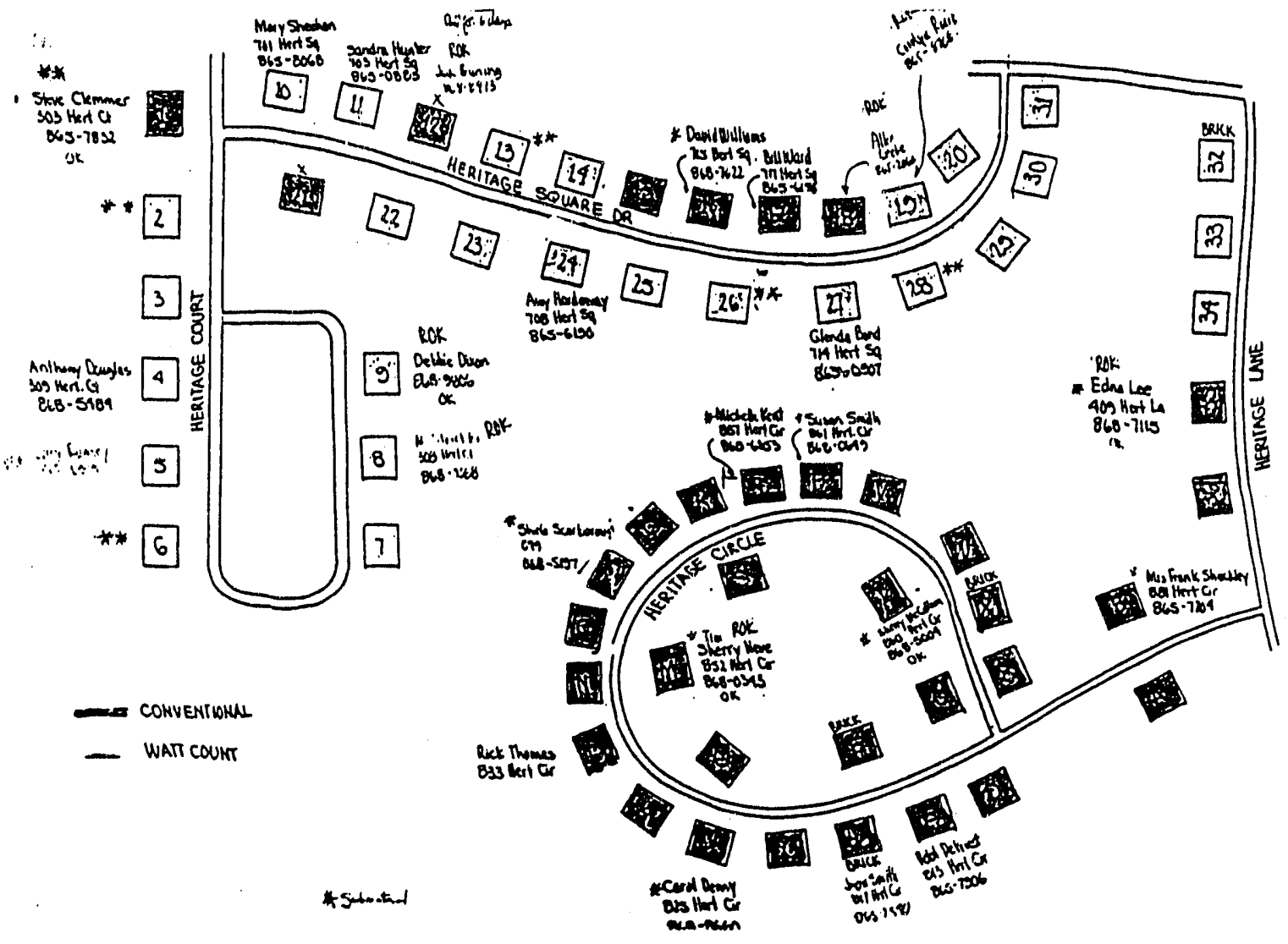

Figure 12 Site Plan for Heritage Square Subdivision 

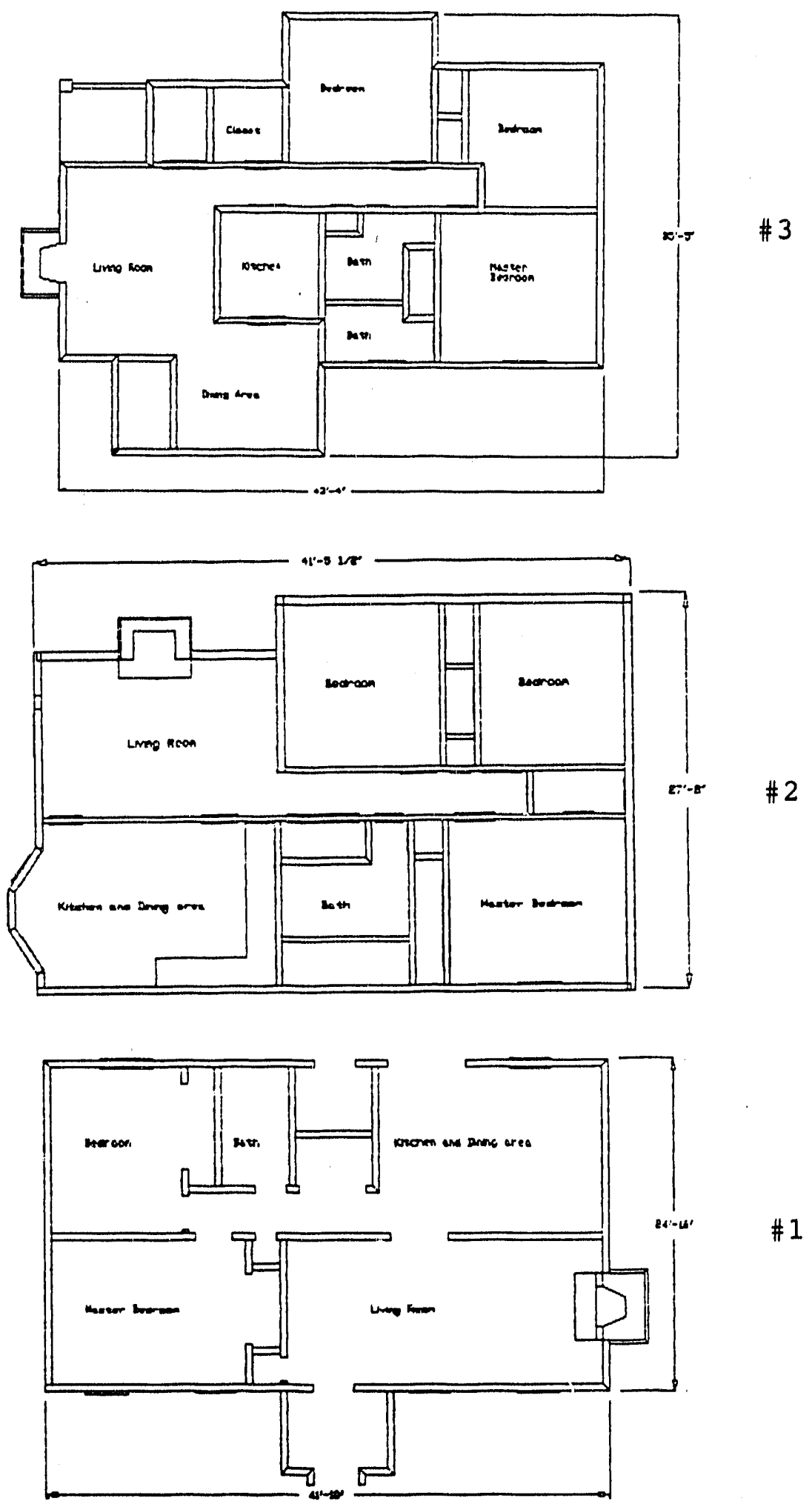
student teams on a daily basis with the exception of weekends beginning in June, 1985 through September, 1986. During the fall, winter, and spring, data were collected sporadically, but two complete sets of summer data are available. The students recorded the date, time, watt-hour submeter reading and utility service watt-hour meter reading for each structure, i.e. 130 daily readings were recorded. These raw field data are presented in Appendix 6 . An index is provided in this appendix to identify the housing unit type with the $\log$ number ( Log \#). Weather data for Nashville were obtained from the National Oceanic and Atmospheric Administration (NOAA) (4). Appendix 7 presents these data for the 1985 and 1986 cooling periods. These data give the dry bulb, wet bulb, and relative humidity at three hour intervals for each day.

\section{Climatic Parameters}

An investigation of the correlation of individual structure cooling usage with various climatic parameters was undertaken. These parameters - cooling degree-hours, cooling degree-days, and average outdoor dry-bulb temperature for a given time period - were first calculated and correlated among themselves. The base temperature for the degree-hour or degree-day calculations was taken to be $70 \mathrm{~F}$, i.e., it was assumed that when the outdoor dry-bulb 
temperature was equal to or greater than $70 \mathrm{~F}$, that mechanical cooling of the structure would be required to maintain comfortable indoor conditions.

The climatic parameters are mathematically determined as follows:

$$
\begin{aligned}
& \text { CLDHR }=\sum_{t}(\text { Tavg }-70 \mathrm{~F}) /(\mathrm{t}) \\
& \text { where CLDHR = Cooling degree-hours } \\
& \text { Tavg = Average outdoor dry bulb temperature } \\
& \text { during the time interval } t \\
& \Sigma_{t}=\begin{array}{c}
\text { Summation of degree-hours over a } \\
\text { time period } t
\end{array} \\
& \text { CLDD }=\sum_{t}[(\text { Thigh }-\mathrm{T} 10 \mathrm{w}) / 2]-70 \mathrm{~F} \\
& \text { where CLDD = Cooling degree days } \\
& \text { Thigh = Daily high dry bulb temperature } \\
& \text { Tlow = Daily low dry bulb temperature } \\
& \Sigma_{t}=\begin{array}{c}
\text { Summation of degree days over a time } \\
\text { period } t
\end{array} \\
& \mathrm{AVT}=\sum_{\mathrm{n}}[\mathrm{T}(\mathrm{t})] / \mathrm{n} \\
& \text { where } A V T=\text { Average dry bulb temperature } \\
& T(t)=\text { Dry bulb temperature at time } t \\
& \Sigma=\text { Total number of recorded dry bulb } \\
& n \text { temperatures over a time period } t \text {. }
\end{aligned}
$$

Cooling degree-hours at $11 / 2$ hour increments were calculated using the NOAA weather data and an appropriate computer program. Since weather data were available at three hour intervals, an interpolation procedure was used to estimate the dry bulb temperatures at $11 / 2$ hour increments. The results of these calculations are presented 
in Appendix 7 .

Three time intervals, i.e. four days, one week and two weeks, were selected for comparing the climatic parameters. The time period began on June 14 and ended on September 26 , 1985. None of the time intervals overlapped. The SPSSX Information Analysis System (5) was used on the TSU DEC VAX $11 / 780$ VMS V4.4 Computer System to perform linear regression analyses of these data. Figure 14 presents the scatter plot of the regression analysis at four day intervals of cooling degree-days (CLDD) vs cooling degree-hours (CLDHR). The correlation coefficient $R$ is 0.46808 which is poor since values of $R=1.0$ or -1.0 would imply perfect correlation. This is not a particularly surprising result due to the possible transient variability of the dry bulb temperature over a forty-eight hour period. Consider Figure 15, which yields similar cooling degree days but significantly different cooling degree-hours for June 17 and June 18,1985 . When the average outdoor temperature (AVT) is compared to cooling degree-hours, the correlation is improved with an $R=0.74213$ as shown in the scatter plot in Figure 16 .

When a one week time interval is selected, the correlations of the climatic parameters improve, indicating perhaps that the transient effects are integrated or 


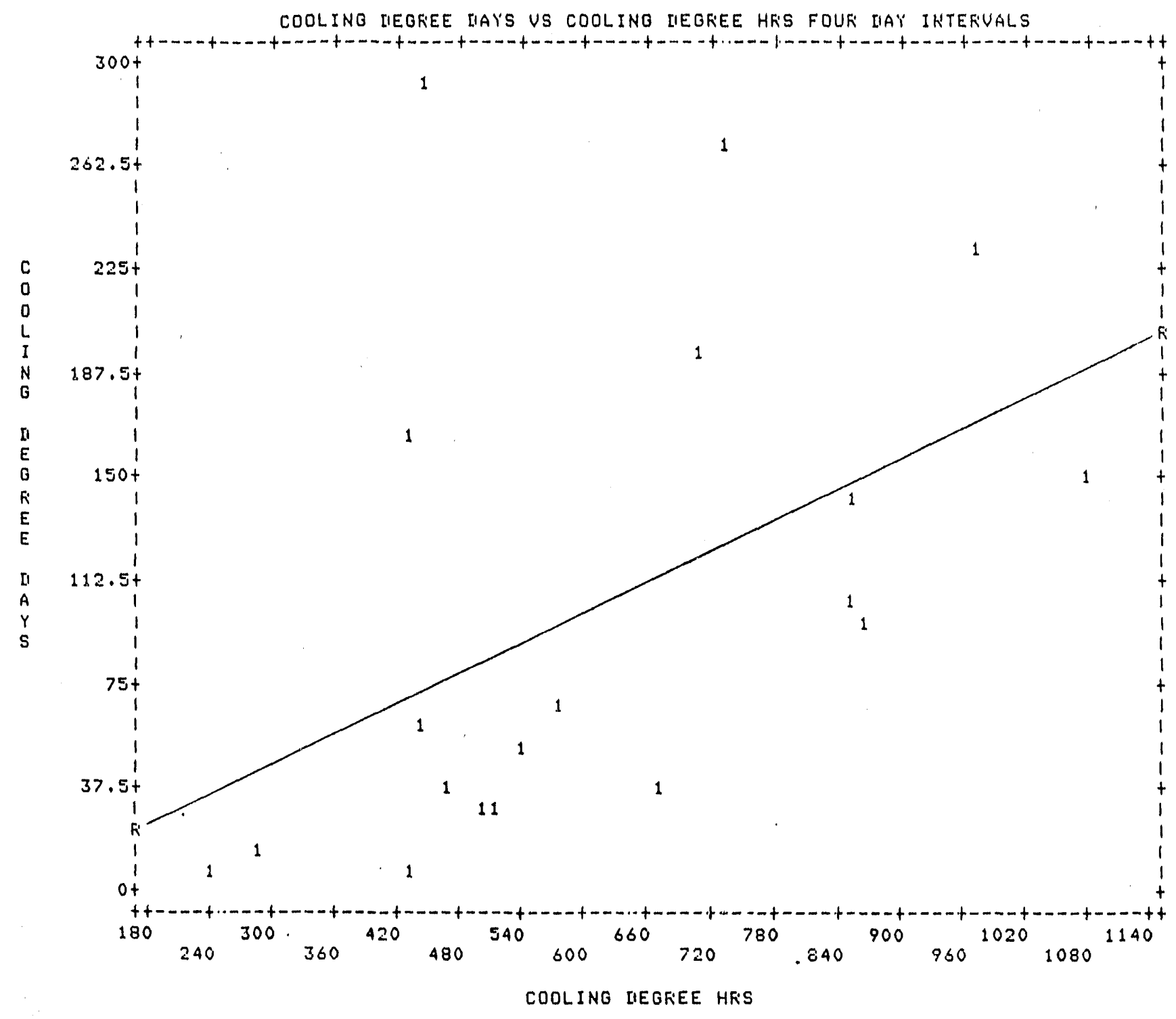

Figure 14 Cooling Degree-Days vs Cooling Degree-Hours for Four-Day Intervals 


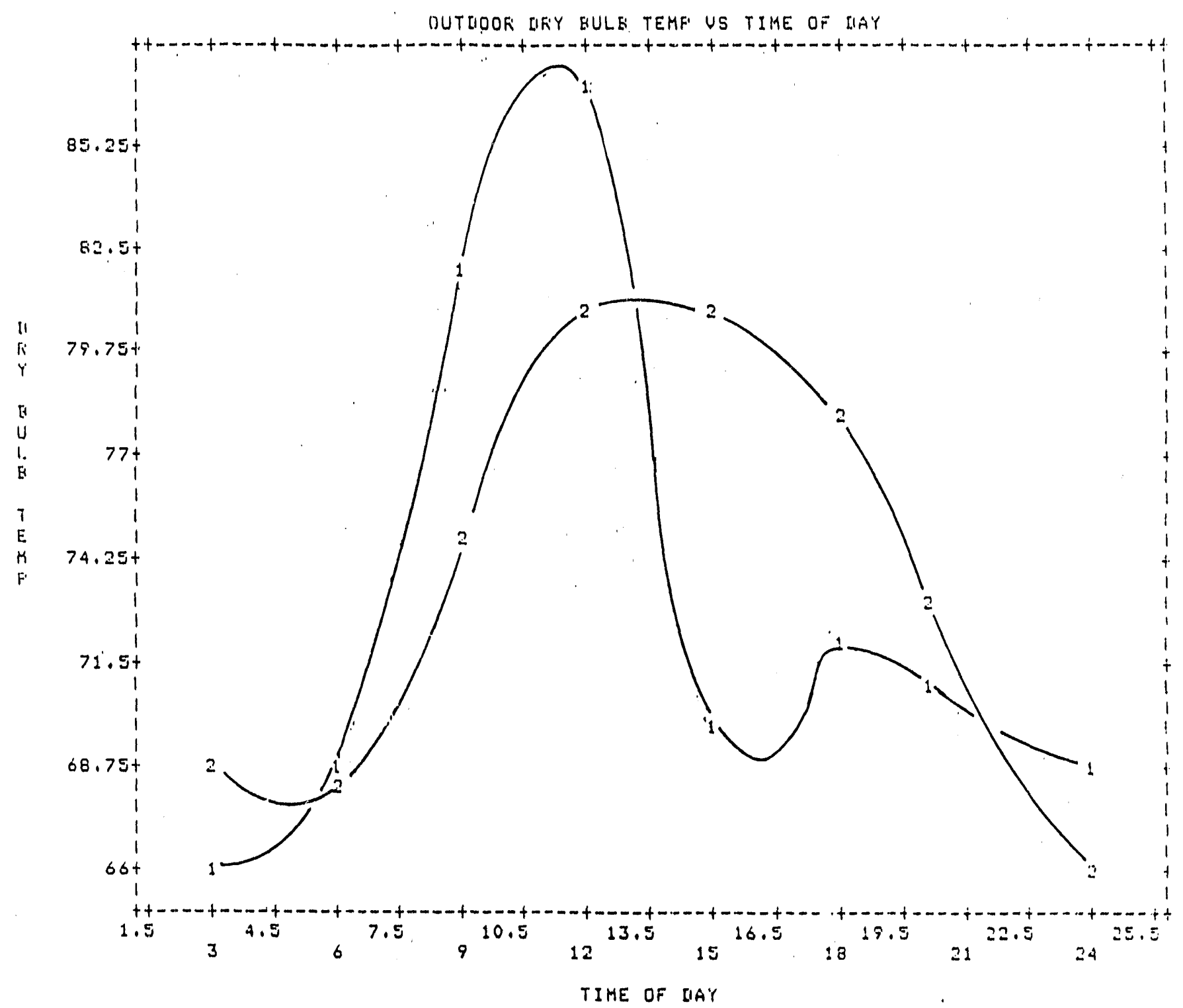

Figure 15 Outdoor Dry Bulb Temperature vs Time of Day for June 17 and 18, 1985 


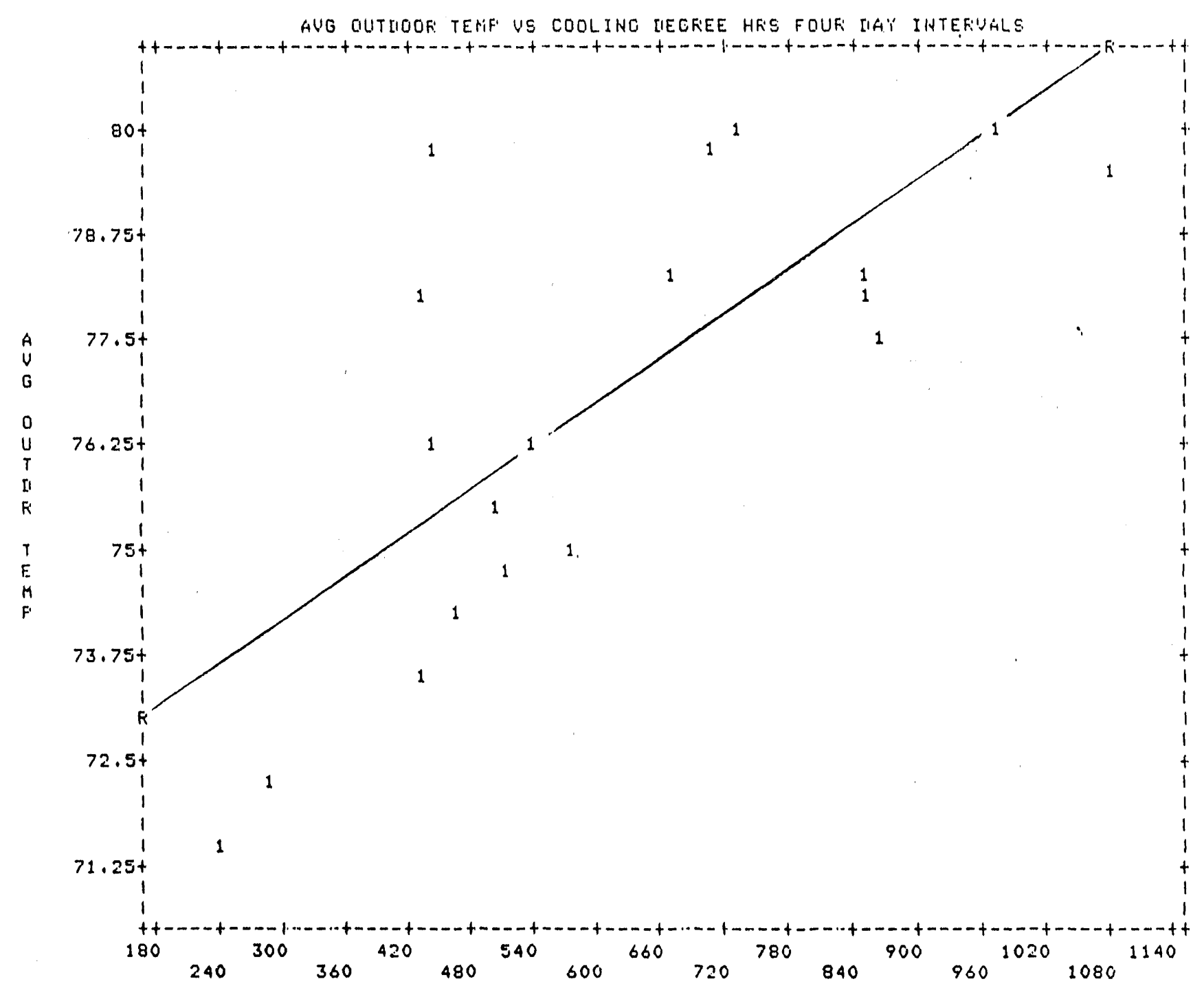

COOLING IIEGREE HFS

Figure 16 Average Outdoor Dry Bulb Temperature vs Cooling Degree-Hours for Four-Day Intervals 
smoothed out when compared to a shorter time interval. Figures 17 and 18 compare CLDD and AVT with CLDHR respectively with corresponding correlation coefficients of 0.78661 and 0.85981 . For two week intervals only four data points were available for the 1985 period. The correlation coefficients vastly improved. The scatter plots in Figures 19 and 20 give $R$ values of 0.99649 and 0.96092 for cooling degree-days and average daily temperature when compared to cooling degree-hours respectively. Table 3 summarizes the results.

$\underline{\text { TABLE }} \underline{3}$

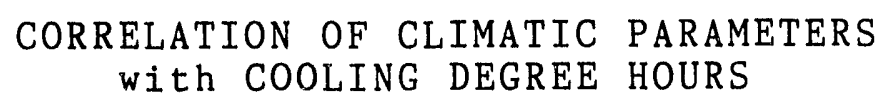
with COOLING DEGREE HOURS

$\begin{array}{ccc}\text { PARAMETER } & \text { TIME } \text { INTERVAL } & \text { R } \\ \text { CLDD } & 4 \text { DAY } & 0.46808 \\ \text { CLDD } & 1 \text { WEEK } & 0.78661 \\ \text { CLDD } & 2 \text { WEEK } & 0.99649 \\ \text { AVT } & 4 \text { DAY } & 0.74213 \\ \text { AVT } & 1 \text { WEEK } & 0.85981 \\ \text { AVT } & 2 \text { WEEK } & 0.96092\end{array}$

When presented in the next section, it will be shown that the individual house cooling usage correlates best with cooling degree-hours for either short time periods or 


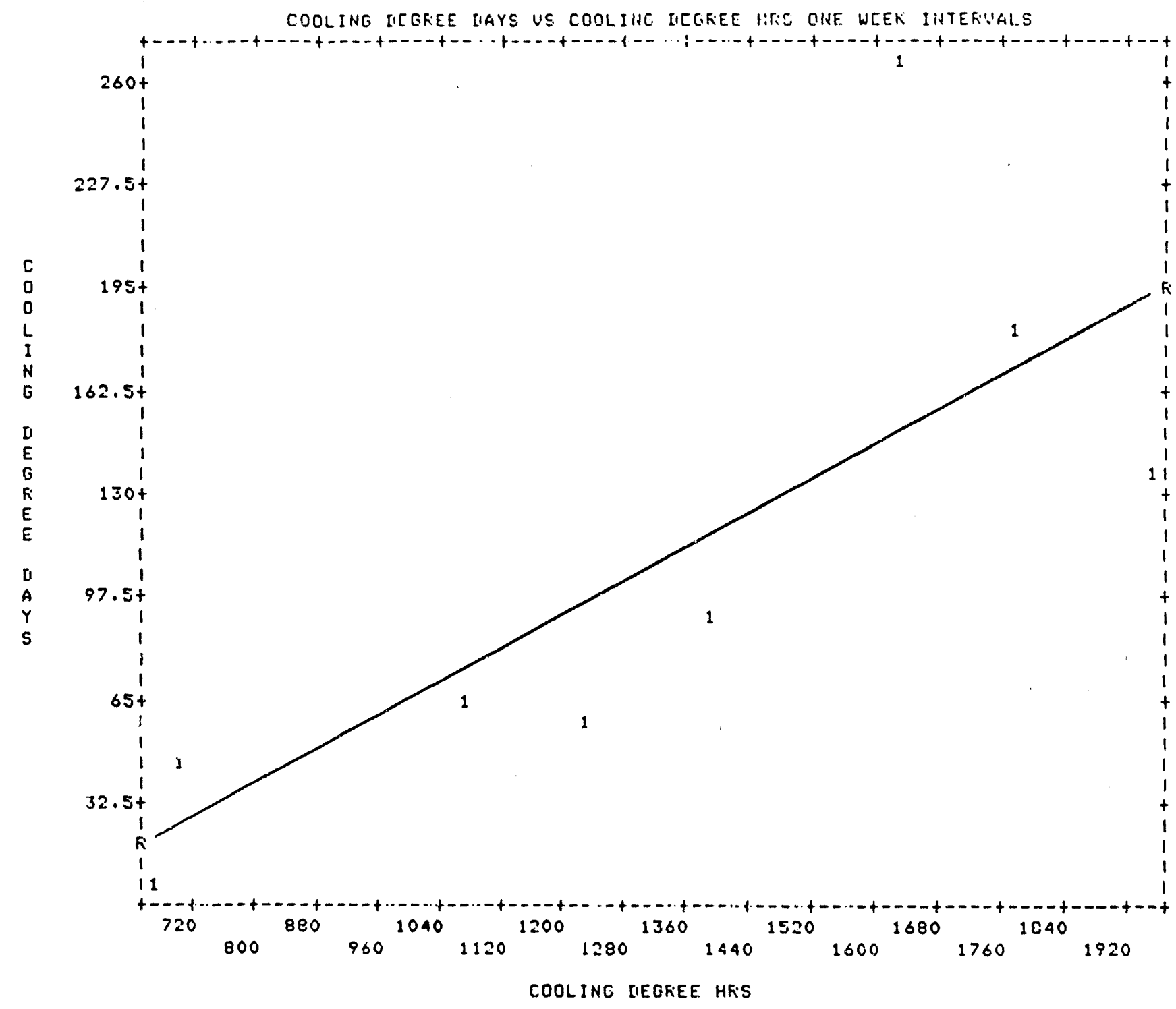

\section{Figure 17 Cooling Degree-Days vs Cooling Degree-Hours} for One-Week Intervals 


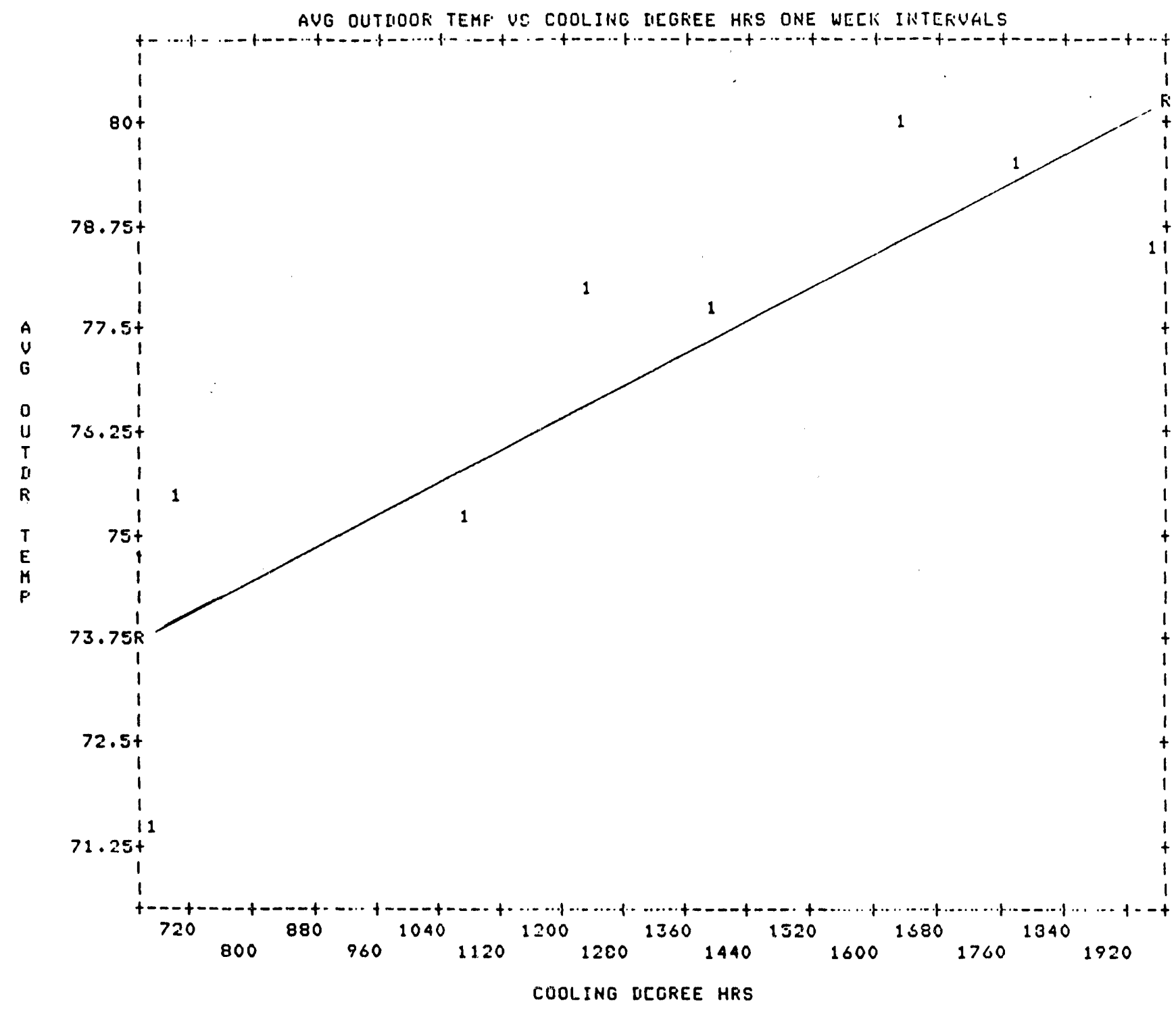

Figure 18 Average Outdoor Dry Bulb Temperature vs Cooling Degree-Hours for One-Week Intervals 


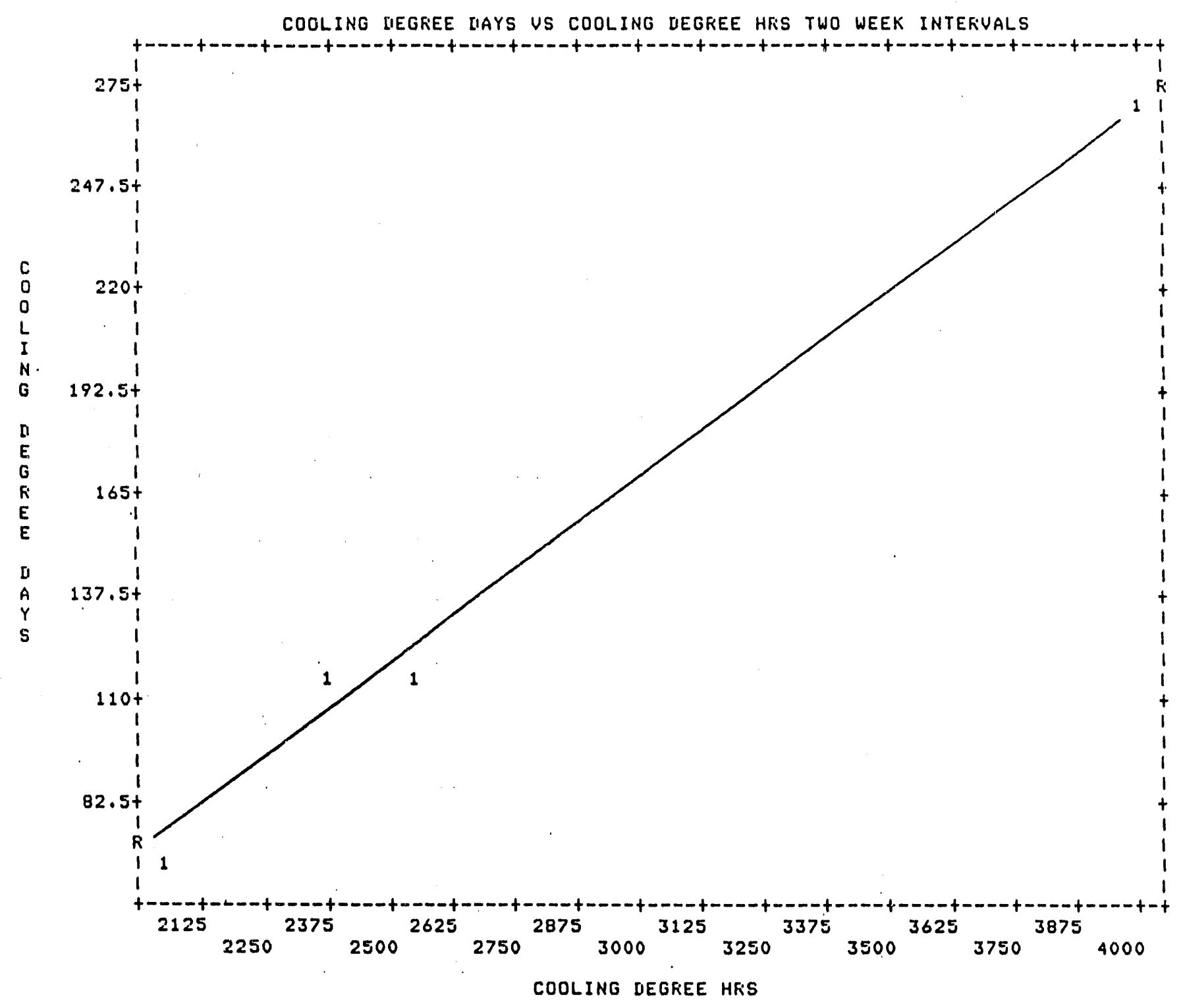

Figure 19 Cooling Degree-Days vs Cooling Degree Hours for Two-Week Intervals 


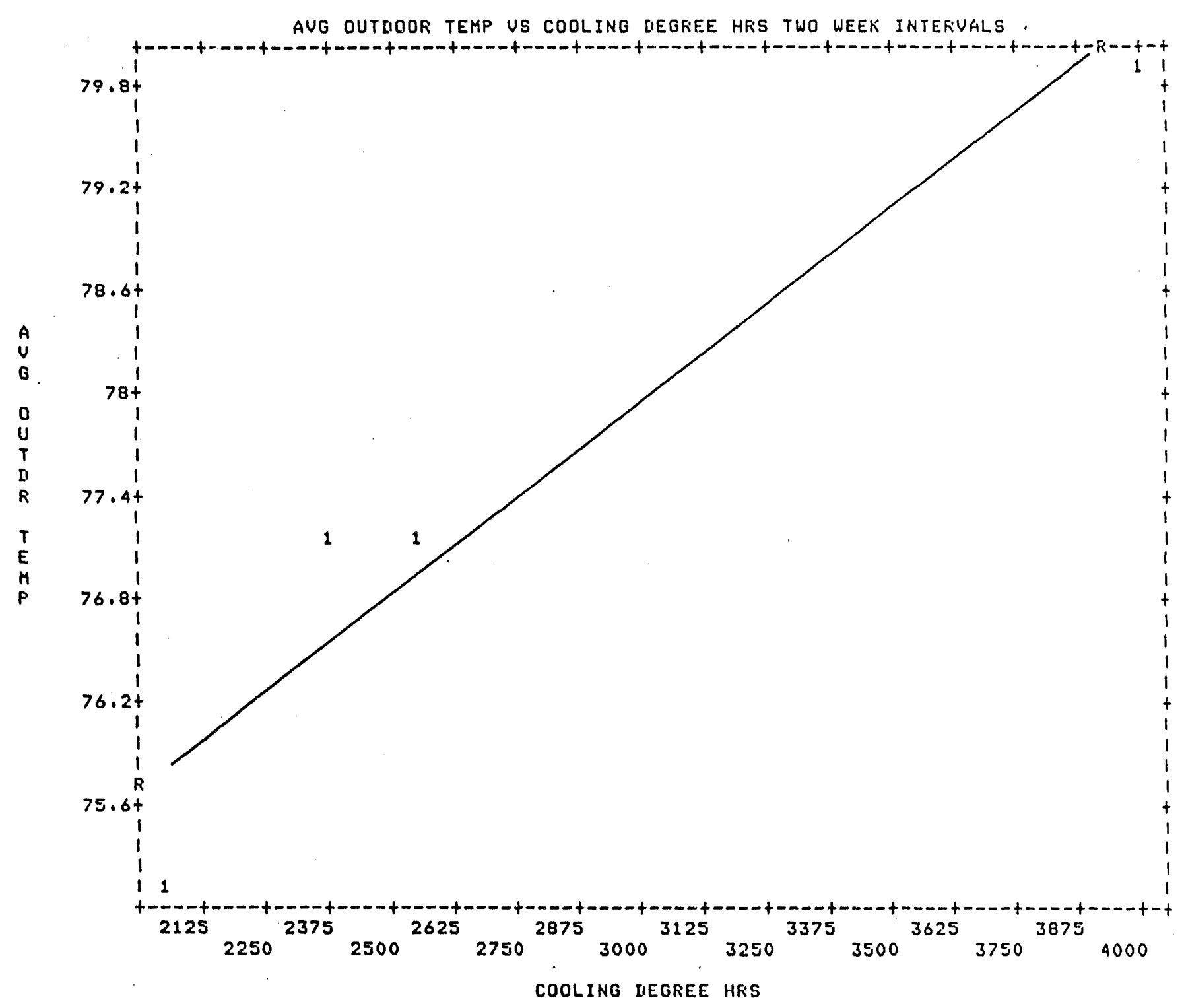

Figure 20 Average Outdoor Dry Bulb Temperature vs

Cooling Degree-Hours for Two-Week Intervals 
relatively long periods. Nevertheless, if one desires to predict the cooling usage for an individual structure over, say, a summer, Table 3 would indicate that cooling degree hours, cooling degree days, or average period temperature could be used with reasonable accuracy if the weather data are known. However, if usage is to be predicted over relatively short periods, the cooling degree hour approach appears to be more accurate.

Cooling Energy Usage for Various Time Intervals

Correlations of an individual structure's cooling usage with the climatic parameters was investigated over various time intervals. Representative units were selected from Brentwood Pointe and Heritage Square.

Figures 21,22 , and 23 present the scatter plots and SPSSx regression analysis results for an A unit (Unit \#3928) at Brentwood Pointe. A time period of four consecutive day intervals was chosen and the KWH cooling usage was plotted against the corresponding cooling degree-hours, degree-days, and average period temperature. Figures 24, 25, and 26 present the scatter plots for the same A unit but for a one week interval. Finally, the energy usage over a two week period are presented in Figures 27,28 , and 29 . Table 4 summarizes the results for this $A^{\circ}$ unit. Figures 30 through 38 present the scatter plots over various time intervals for 


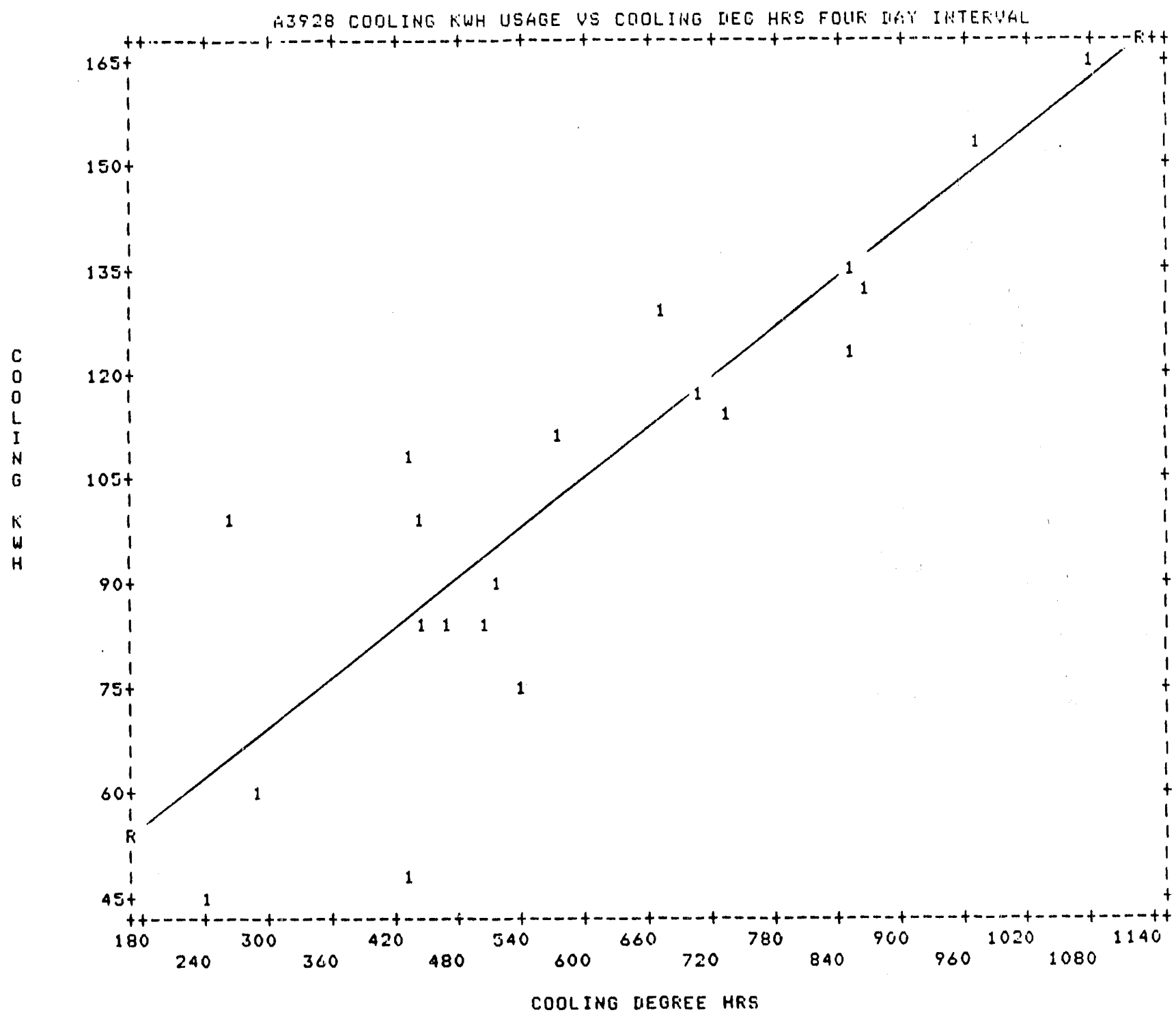

Figure 21 Typical Unit A Cooling Usage vs Cooling Degree-Hours for Four-Day Intervals 


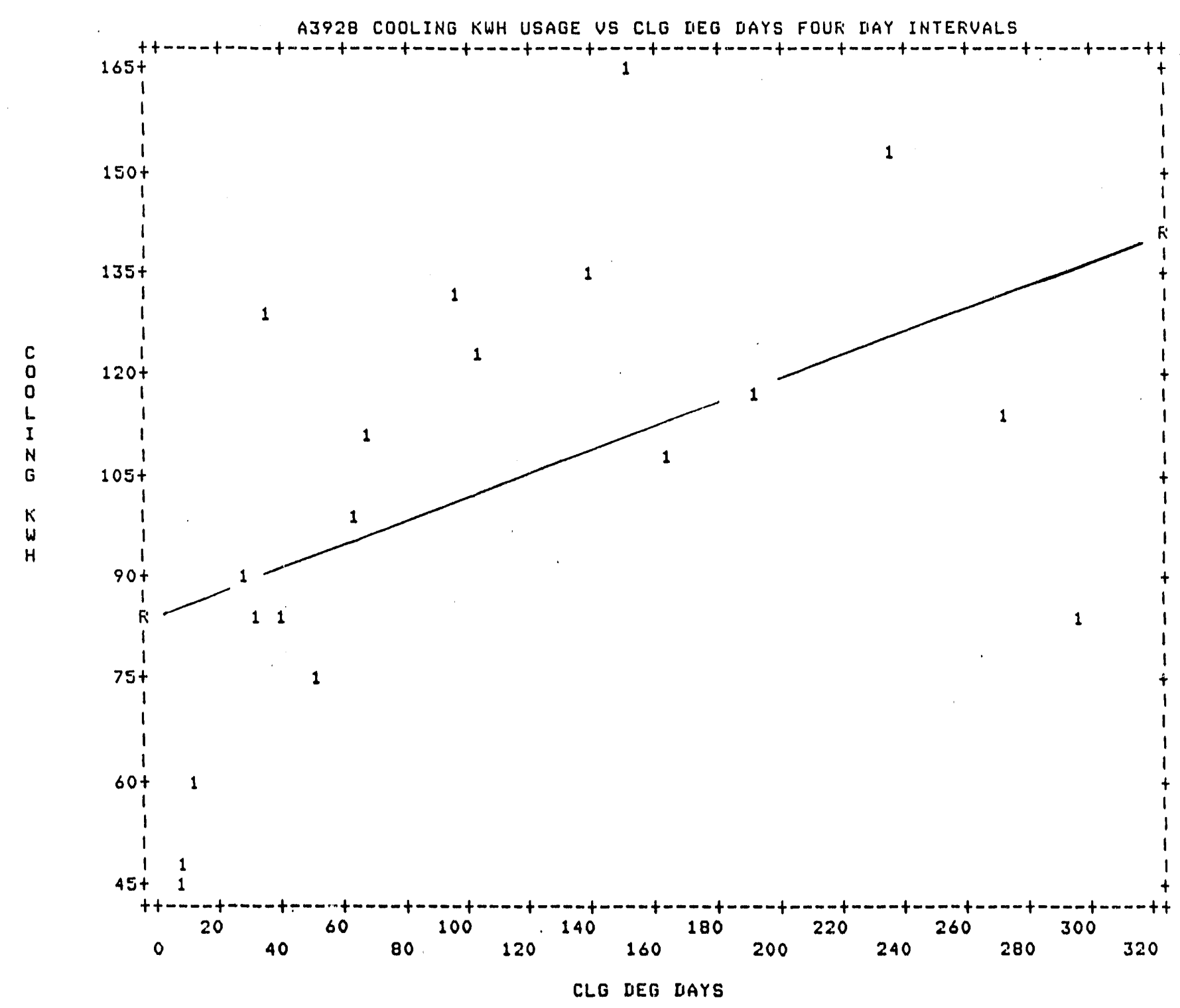

Figure 22 Typical Unit A Cooling Usage vs Cooling Degree-Days for Four-Day Intervals 


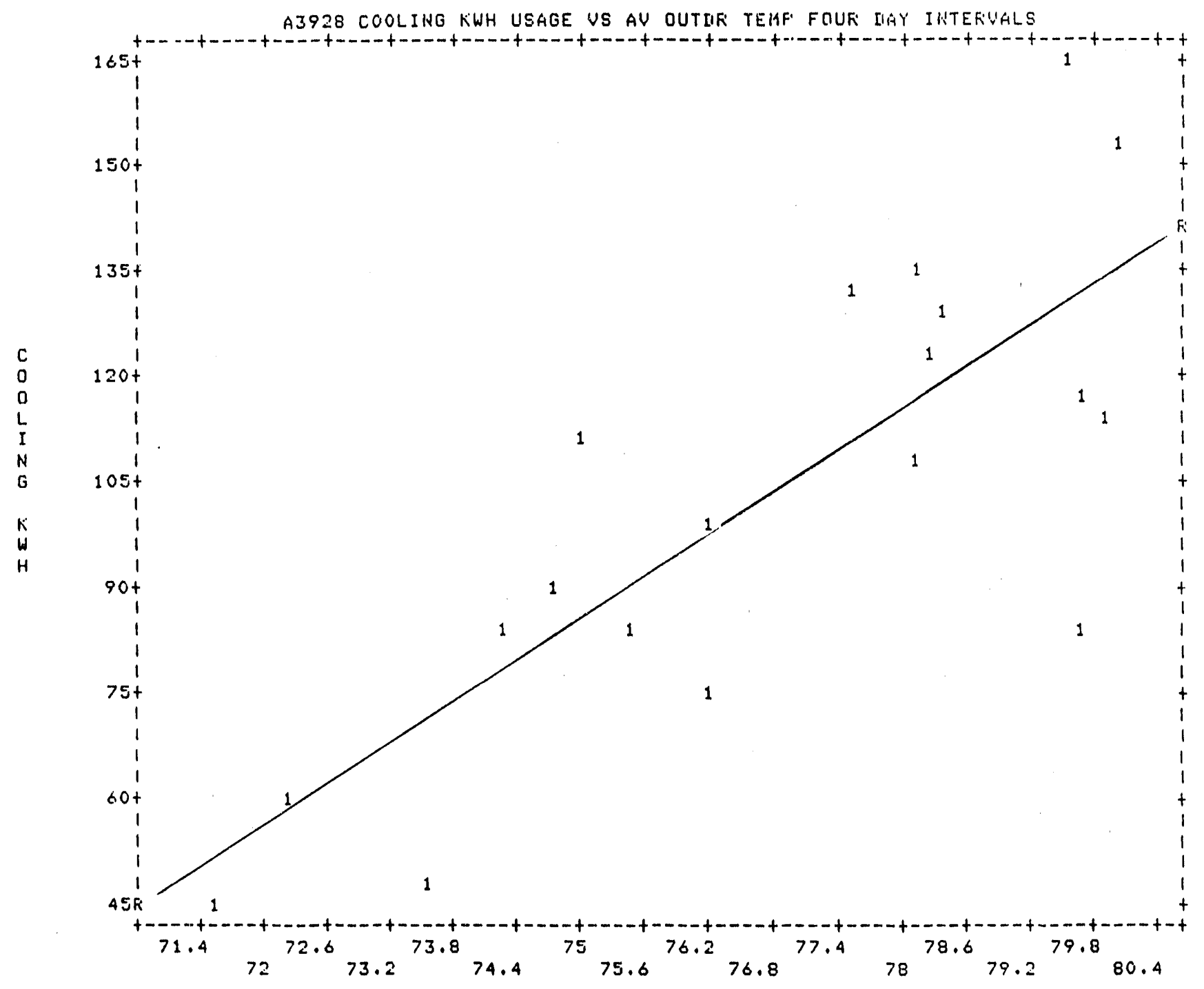

AU OUTUF TEKF

Figure 23 Typical Unit A Cooling Usage vs Average Outdoor Dry Bulb Temperature for Four-Day Intervals 


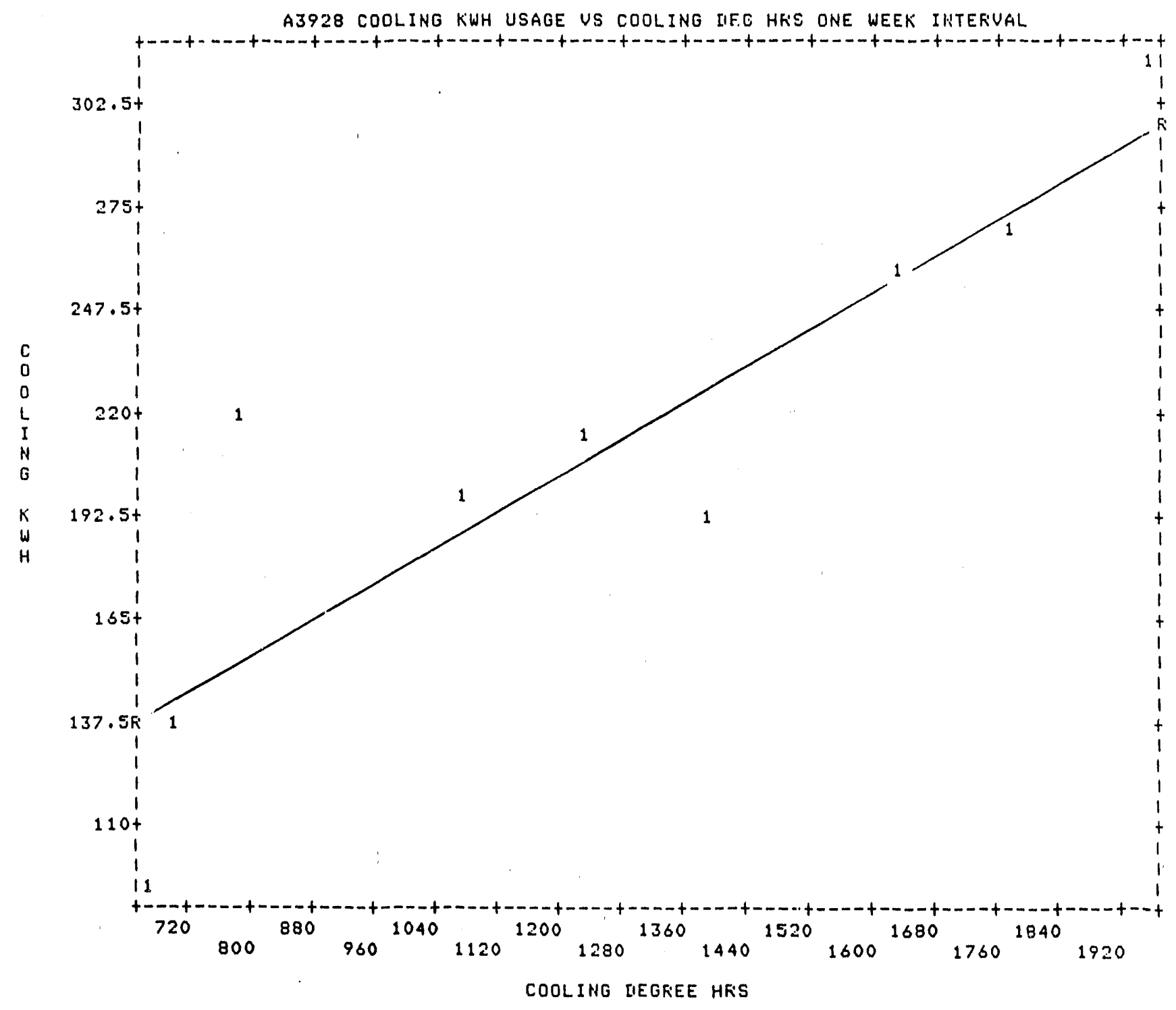

Figure 24 Typical Unit A Cooling Usage vs Cooling Degree-Hours for One-Week Intervals 


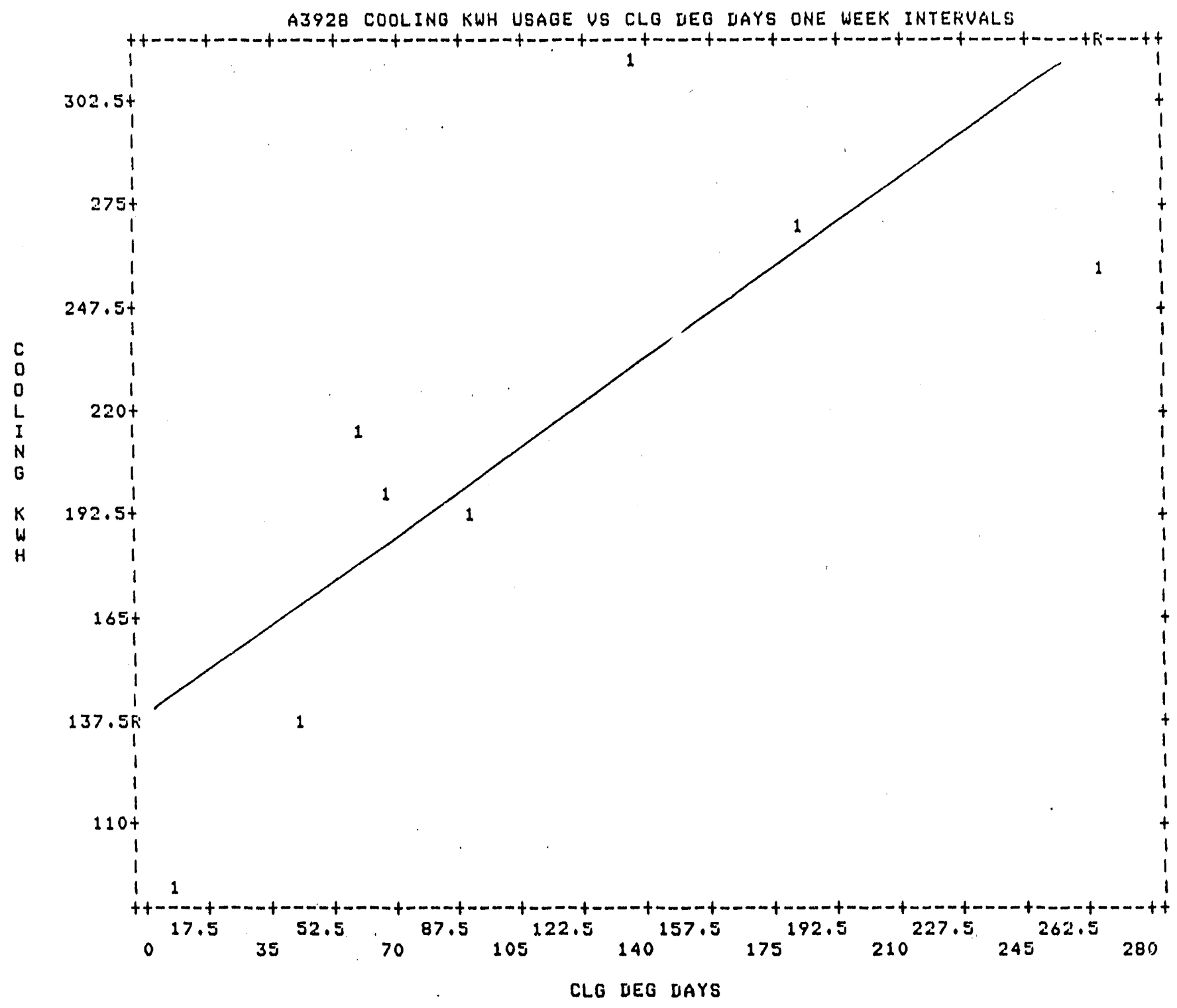

Figure 25 Typical Unit A Cooling Usage vs Cooling Degree-Days for One-Week Intervals 


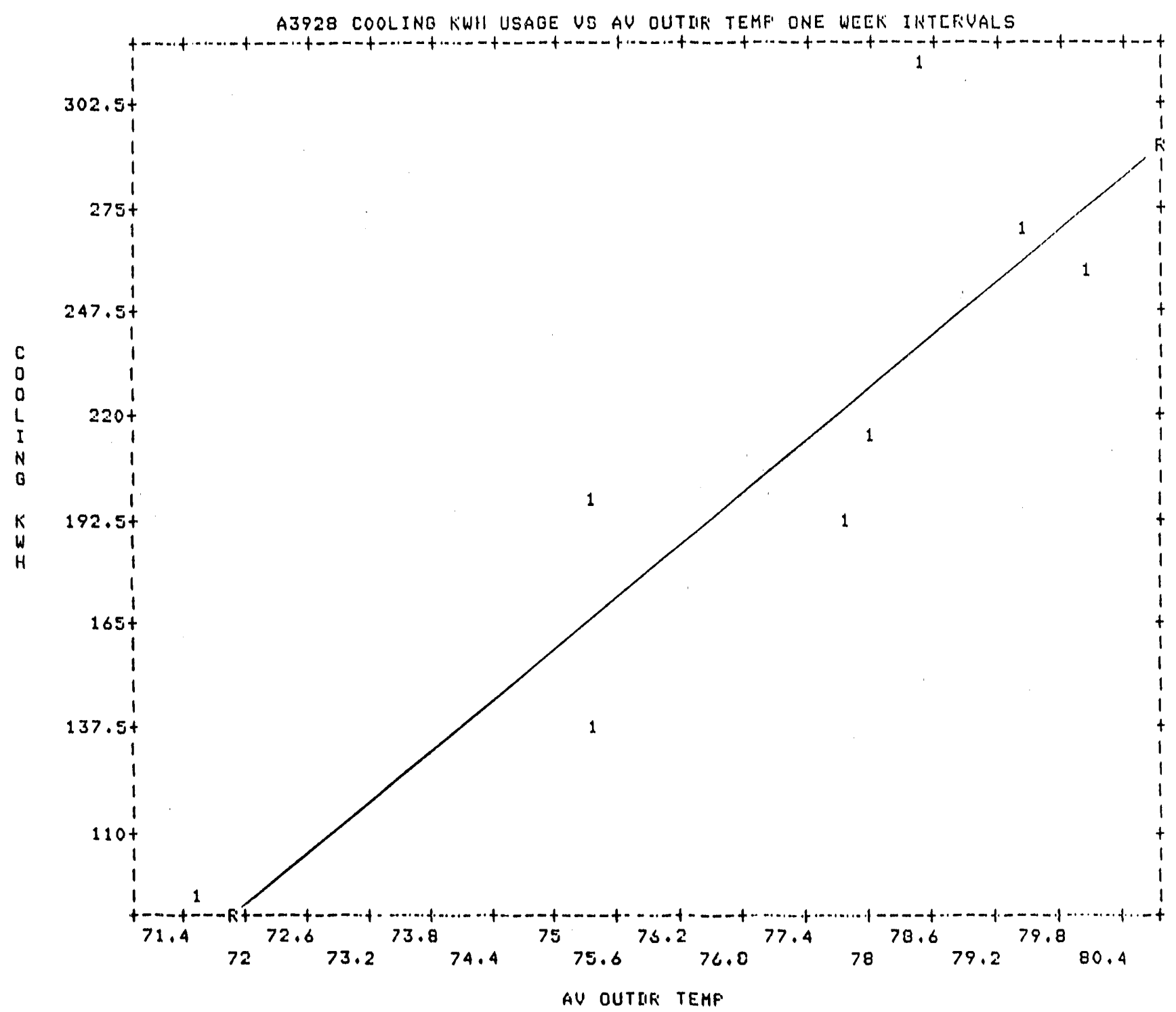

Figure 26 Typical Unit A Cooling Usage vs Average Outdoor Dry Bulb Temperature for One-Week Intervals 


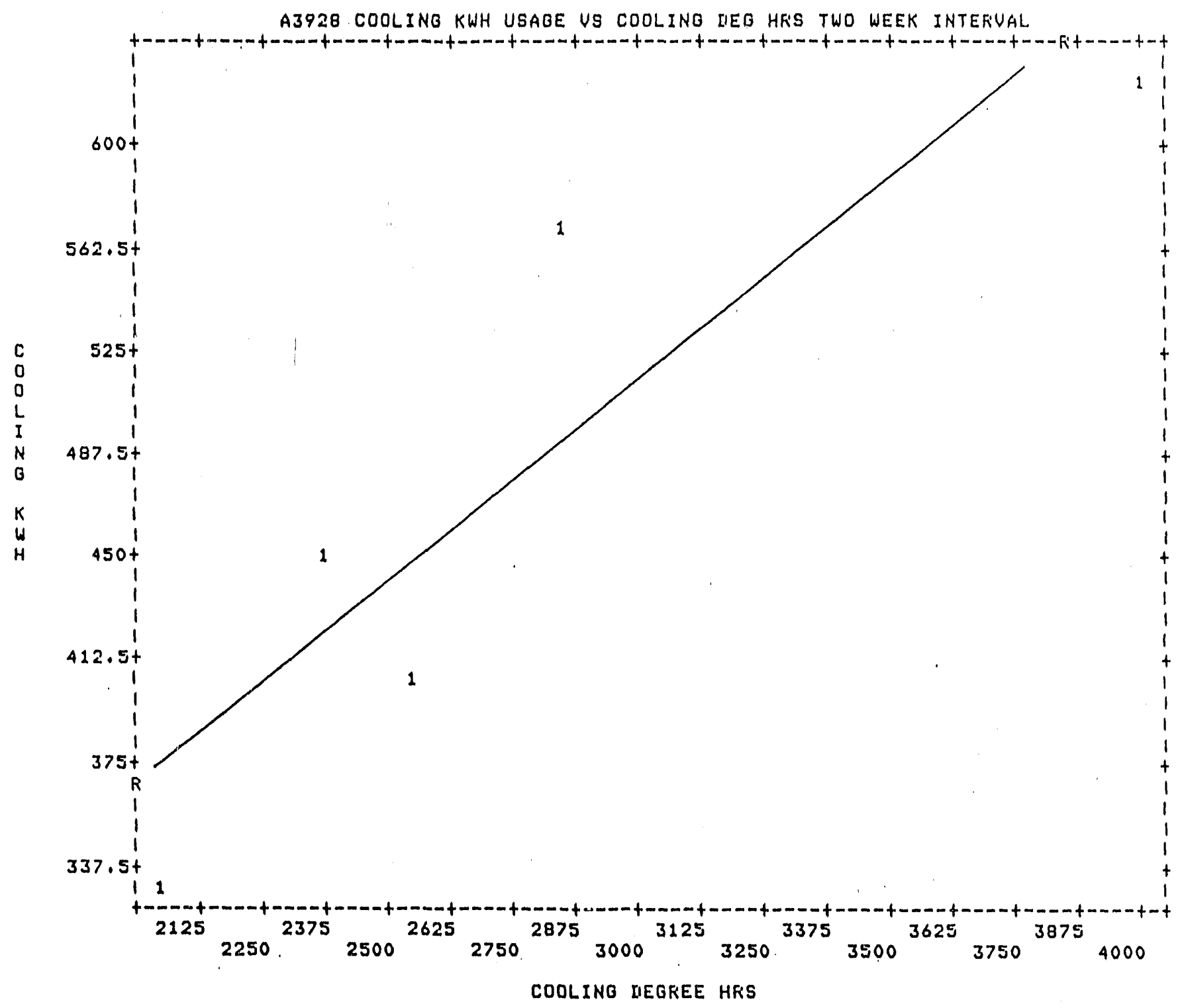

Figure 27 Typical Unit A Cooling Usage vs Cooling Degree-Hours for Two Week Intervals 
A3928 LOOLING KWH USAGE US CLG REG SAYS TWO WEEK INTERVALS

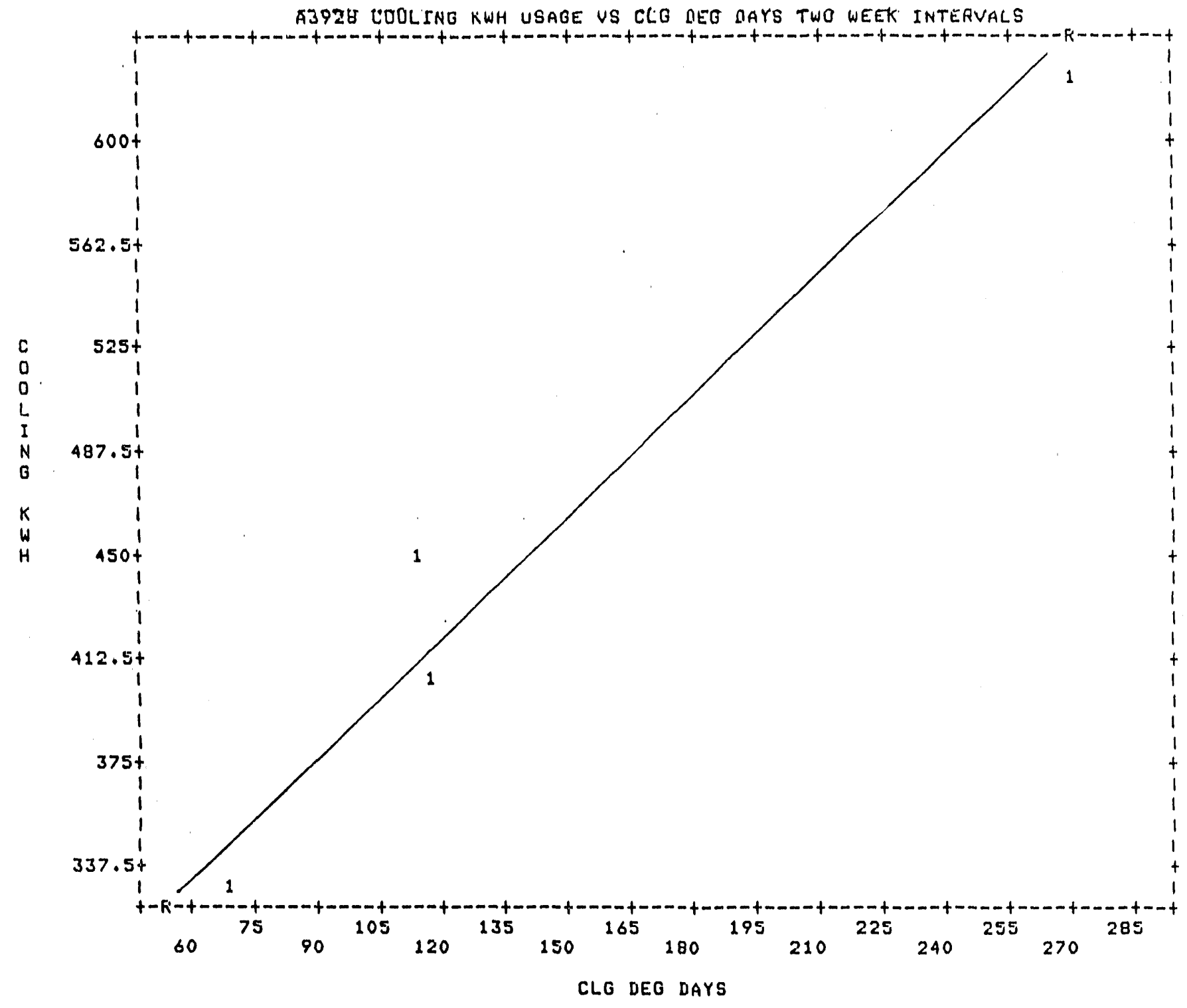

Figure 28 Typical Unit A Cooling Usage vs Cooling Degree-Days for Two-Week Intervals. 


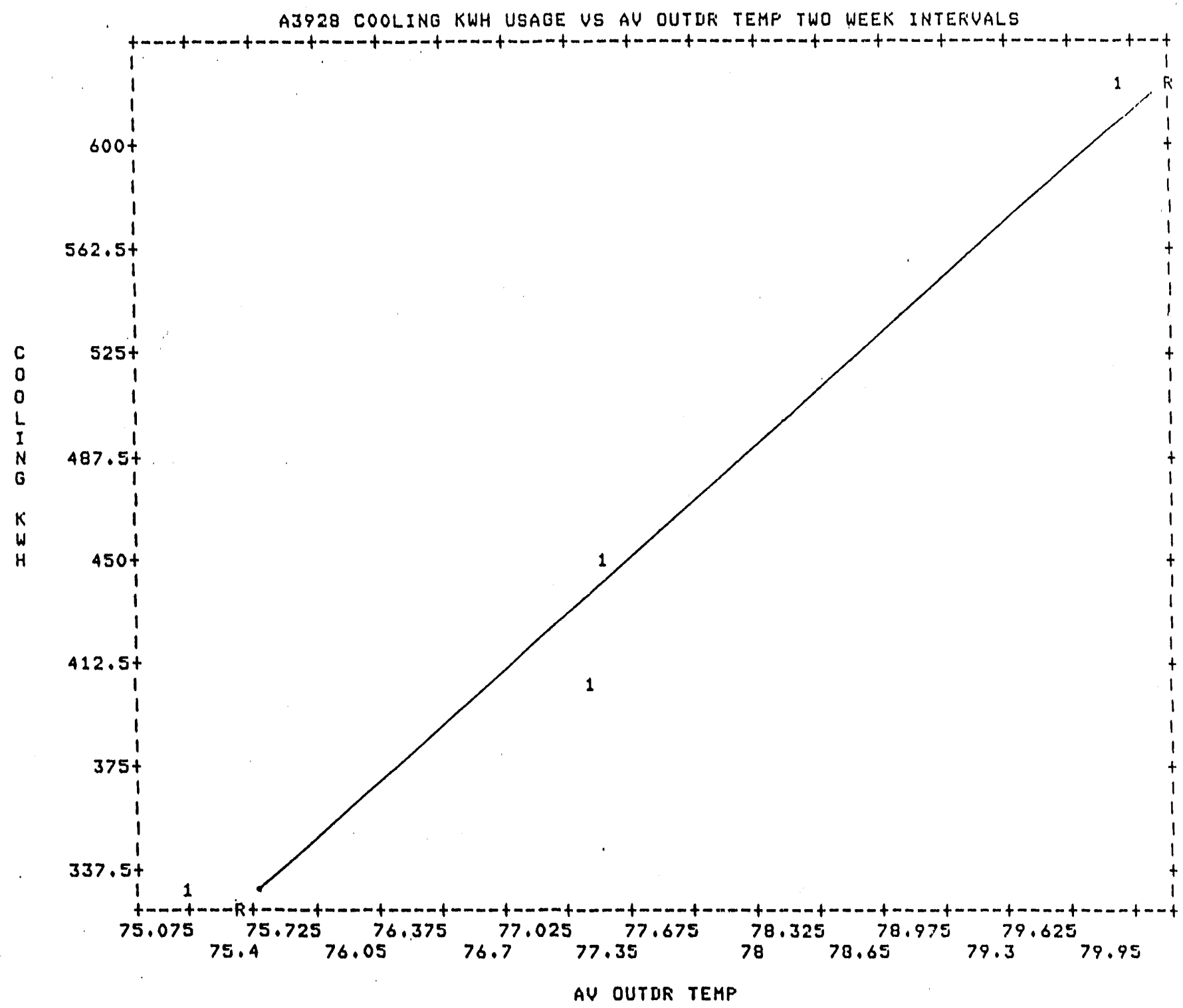

Figure 29 Typical Unit A Cooling Usage vs Average Outdoor Dry Bulb Temperature for Two-Week Intervals 


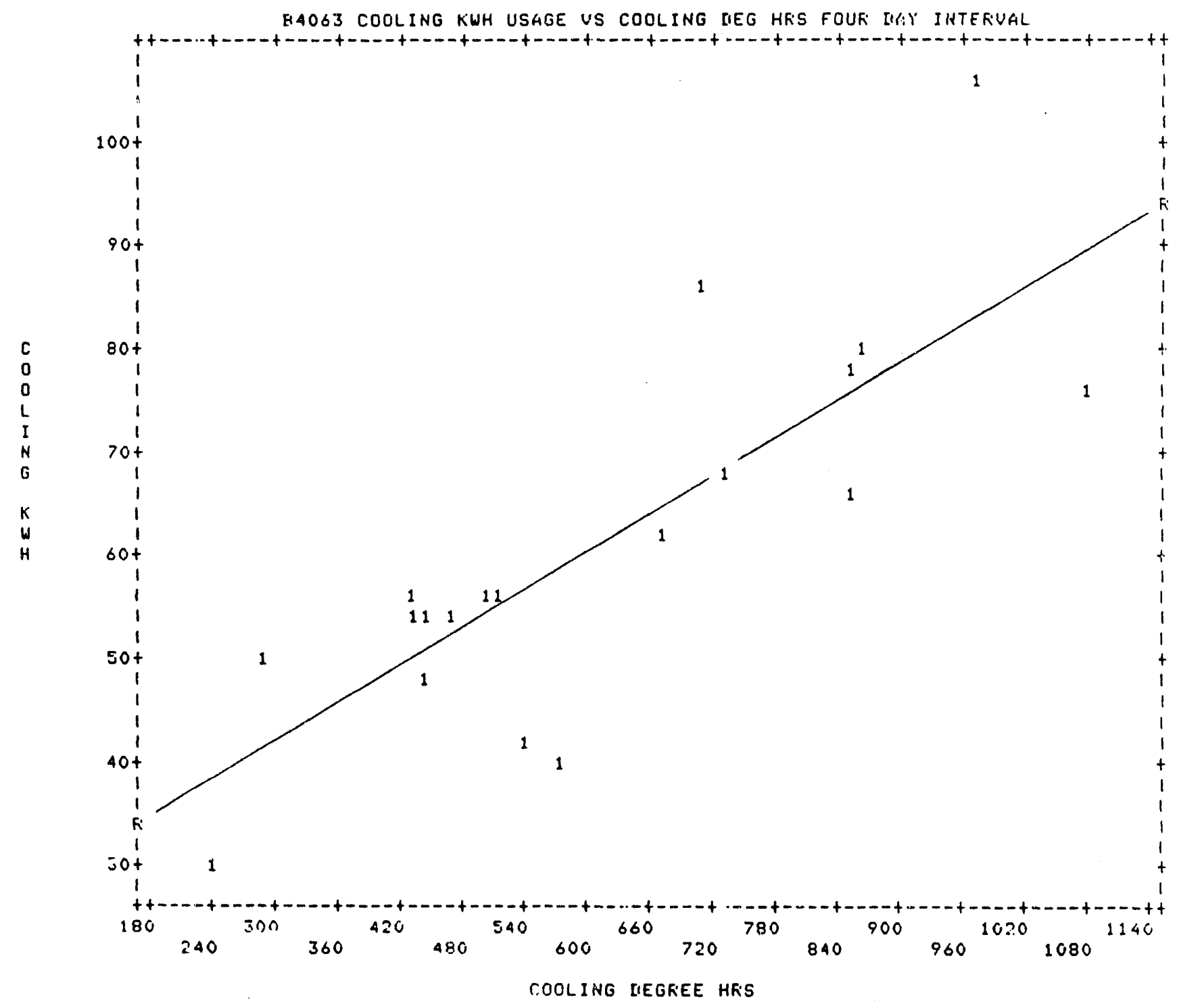

Figure 30 Typical Unit B Cooling Usage vs Cooling Degree-Hours for Four-Day Intervals 


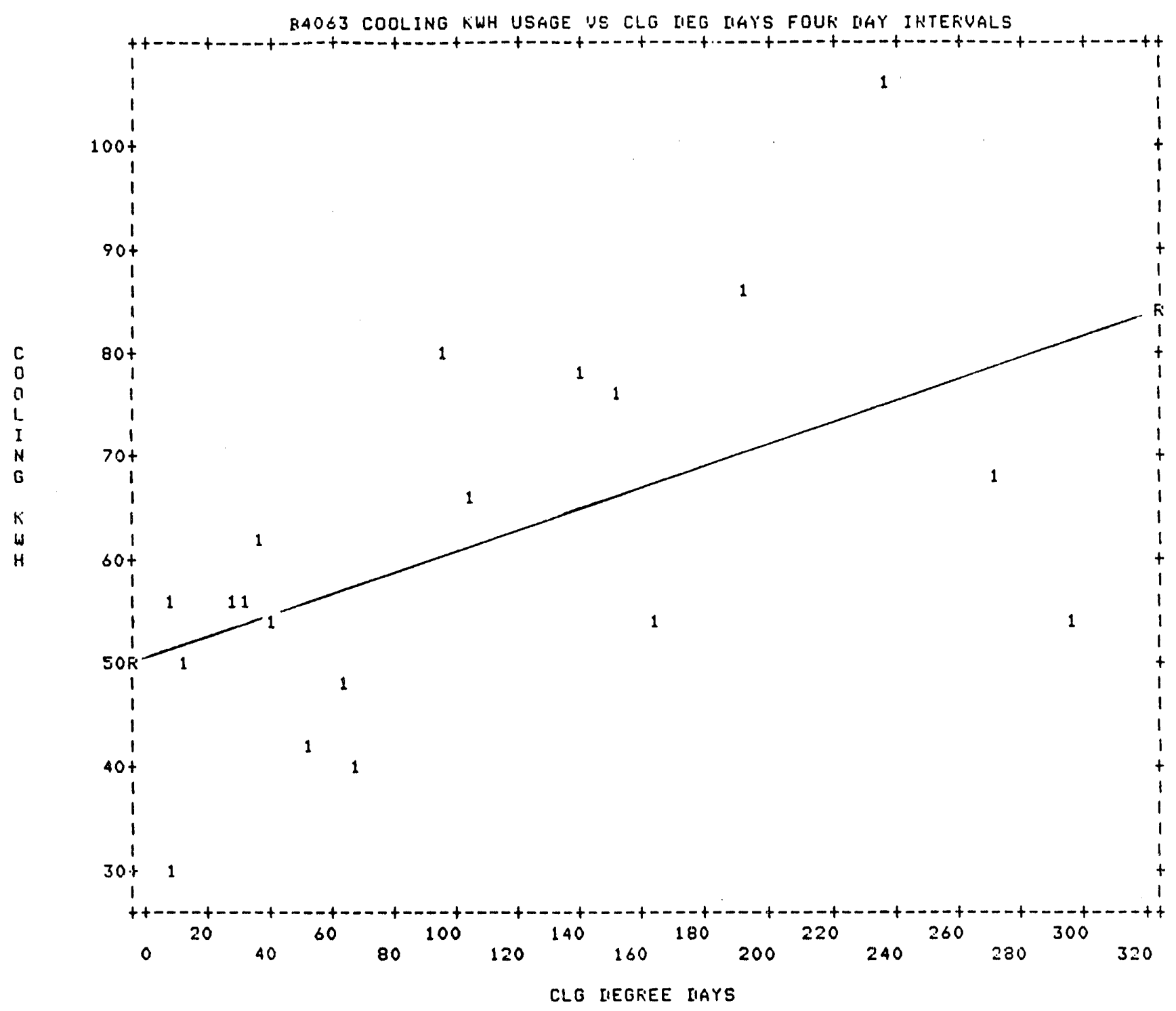

Figure 31 Typical Unit B Cooling Usage vs Cooling Degree-Days for Four-Day Intervals 


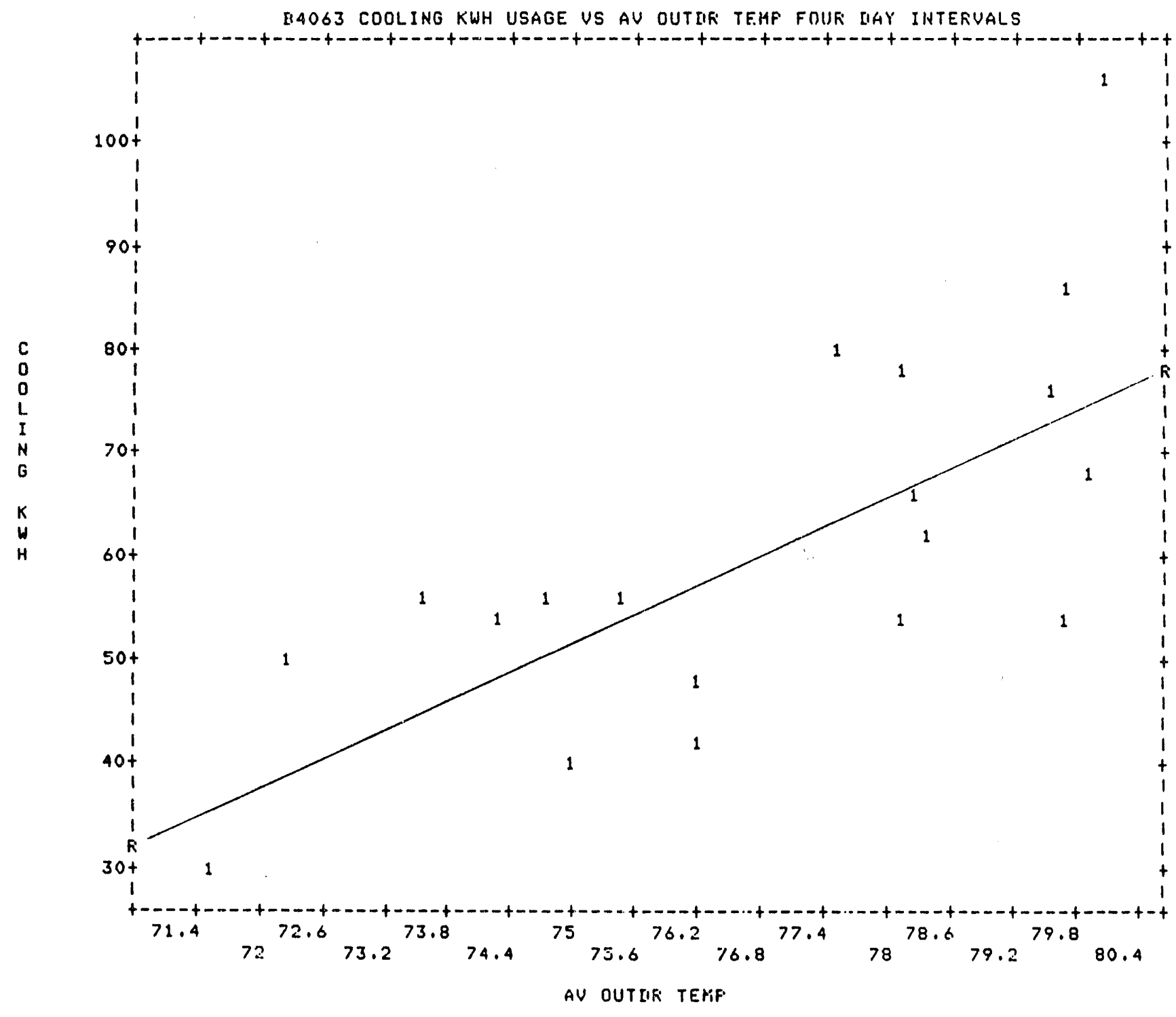

Figure 32 Typical Unit B Cooling Usage vs Average Outdoor Dry Buli Temperature for Four-Day Intervals 


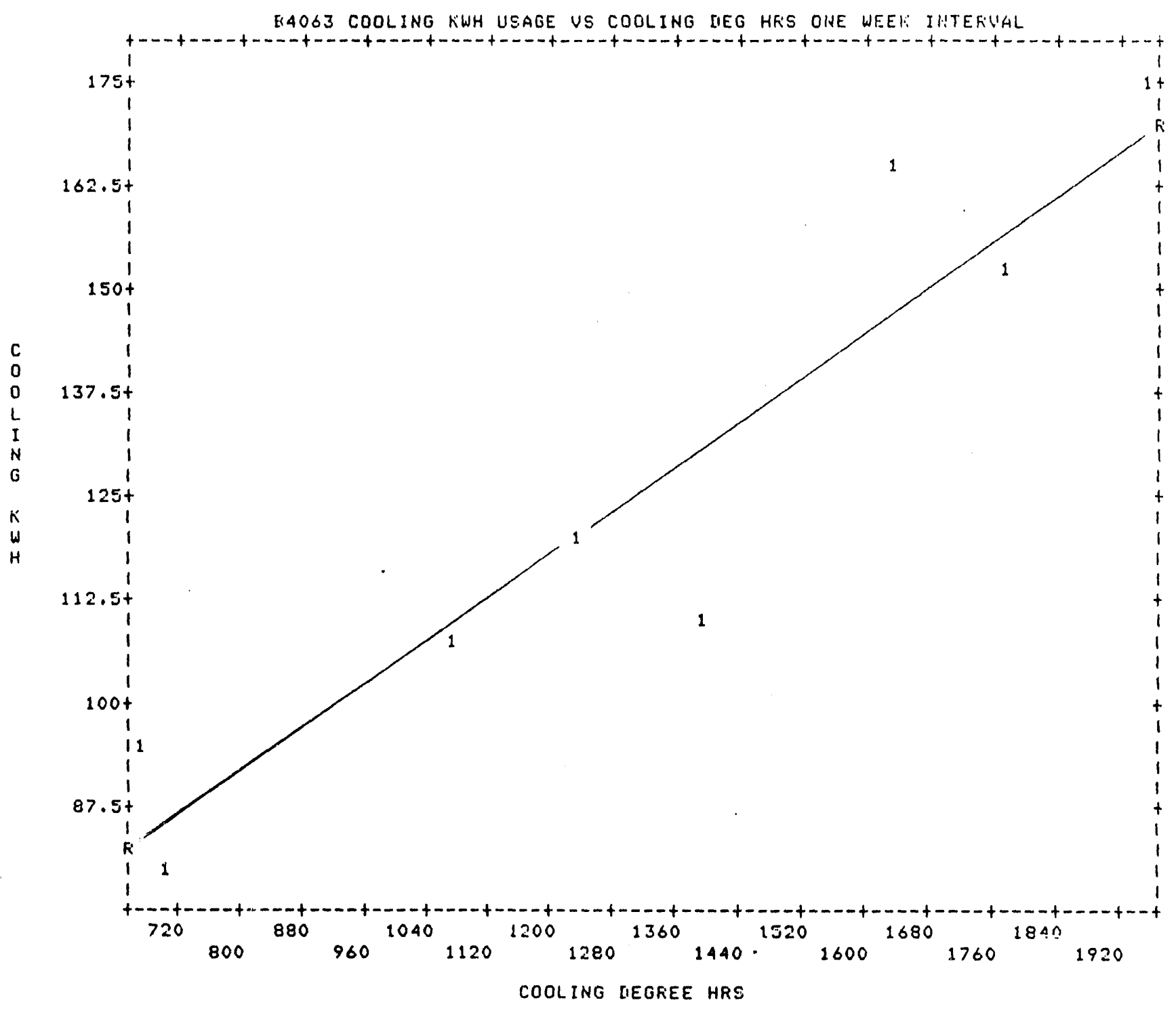

Figure 33 Typical Unit B Cooling Usage vs Cooling Degree-Hours for One-Week Intervals 


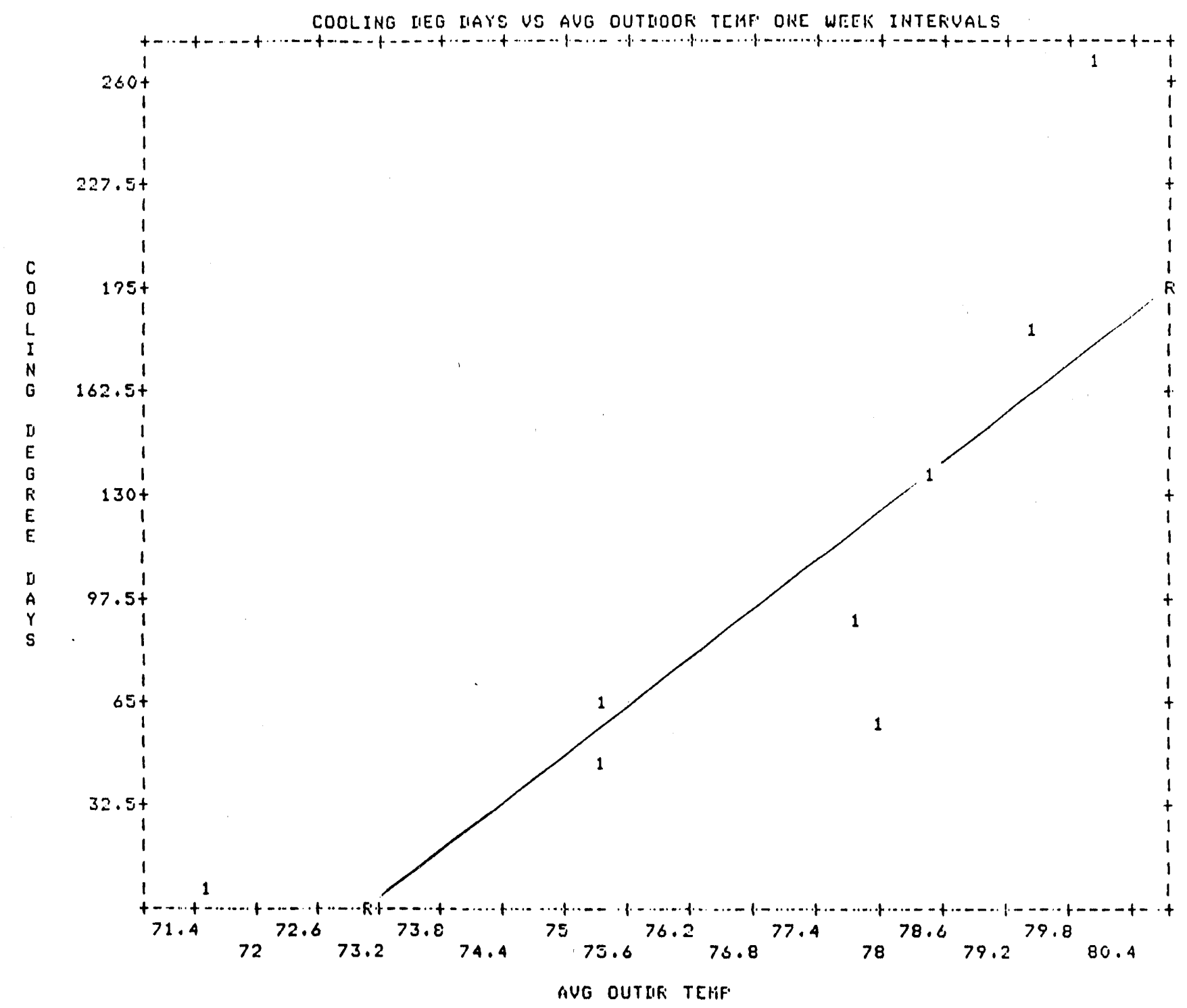

Figure 34 Typical Unit B Cooling Usage vs Cooling Degree-Days for One-Week Intervals 


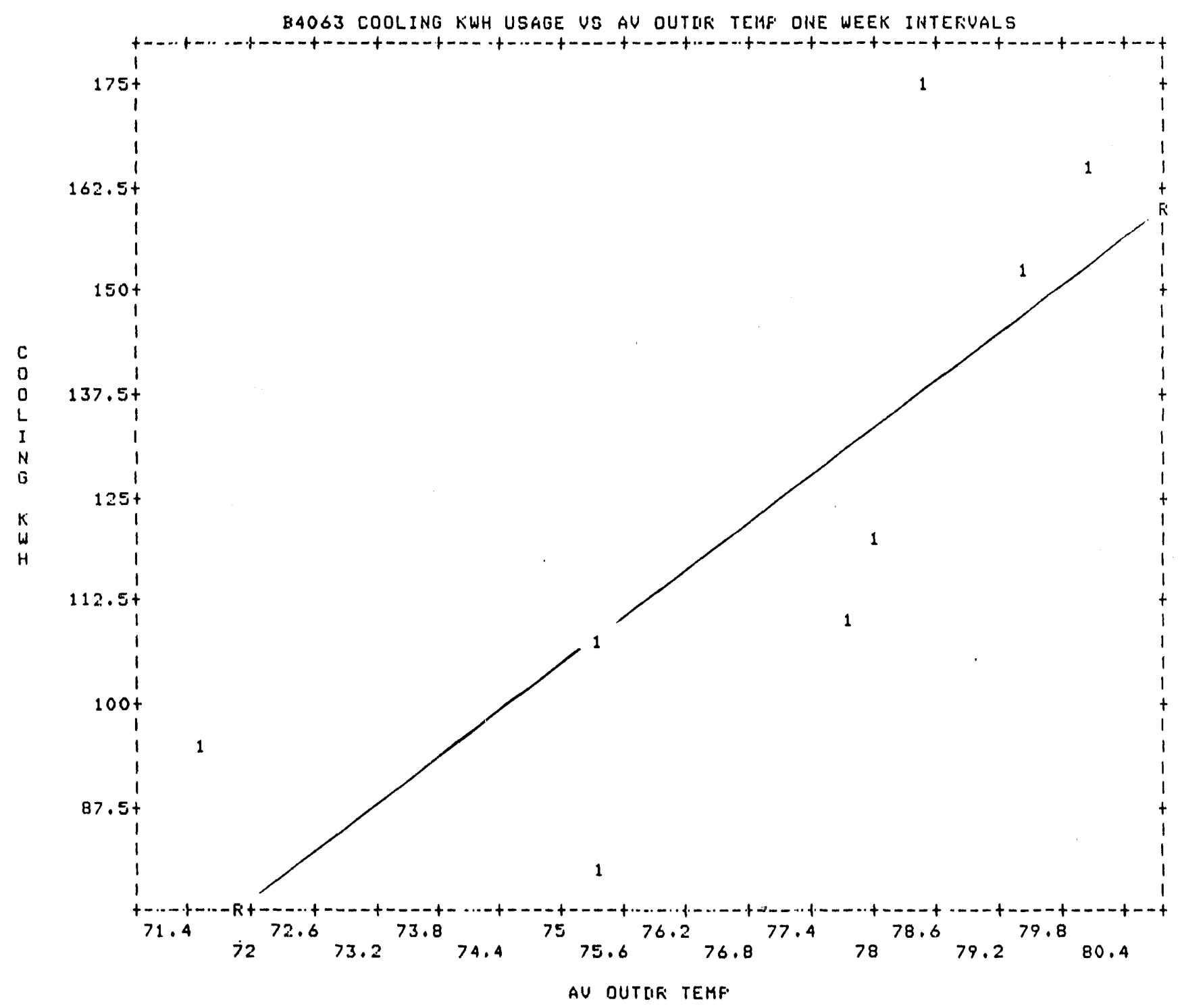

Figure 35 Typical Unit B Cooling Usage vs Average Outdoor Dry Bulb Temperature for One-Week Intervals 


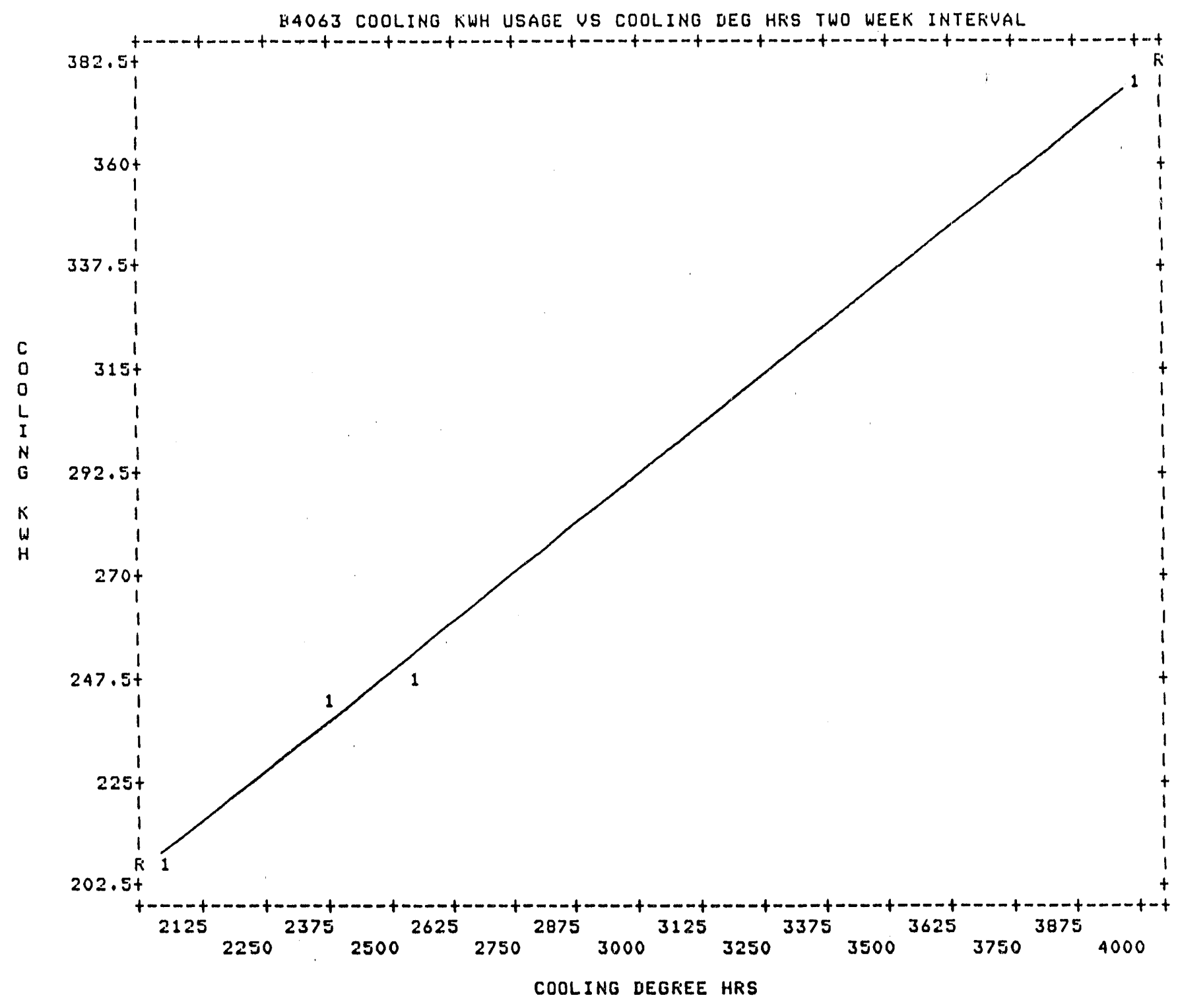

Figure 36 Typical Unit B Cooling Usage vs Cooling Degree-Hours for Two-Week Intervals 


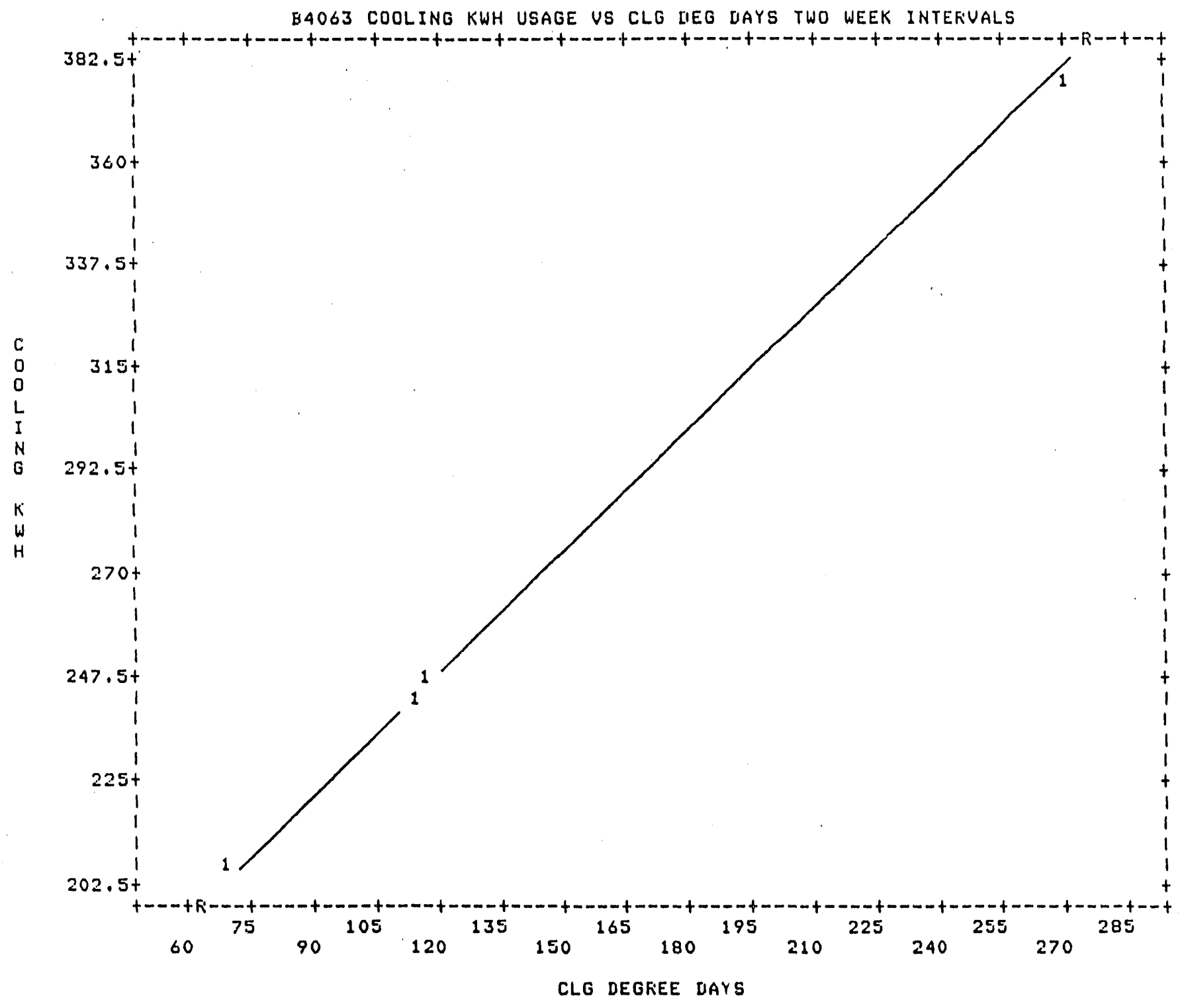

Figure 37 Typical Unit B Cooling Usage vs Cooling Degree-Days for Two-Week Intervals 


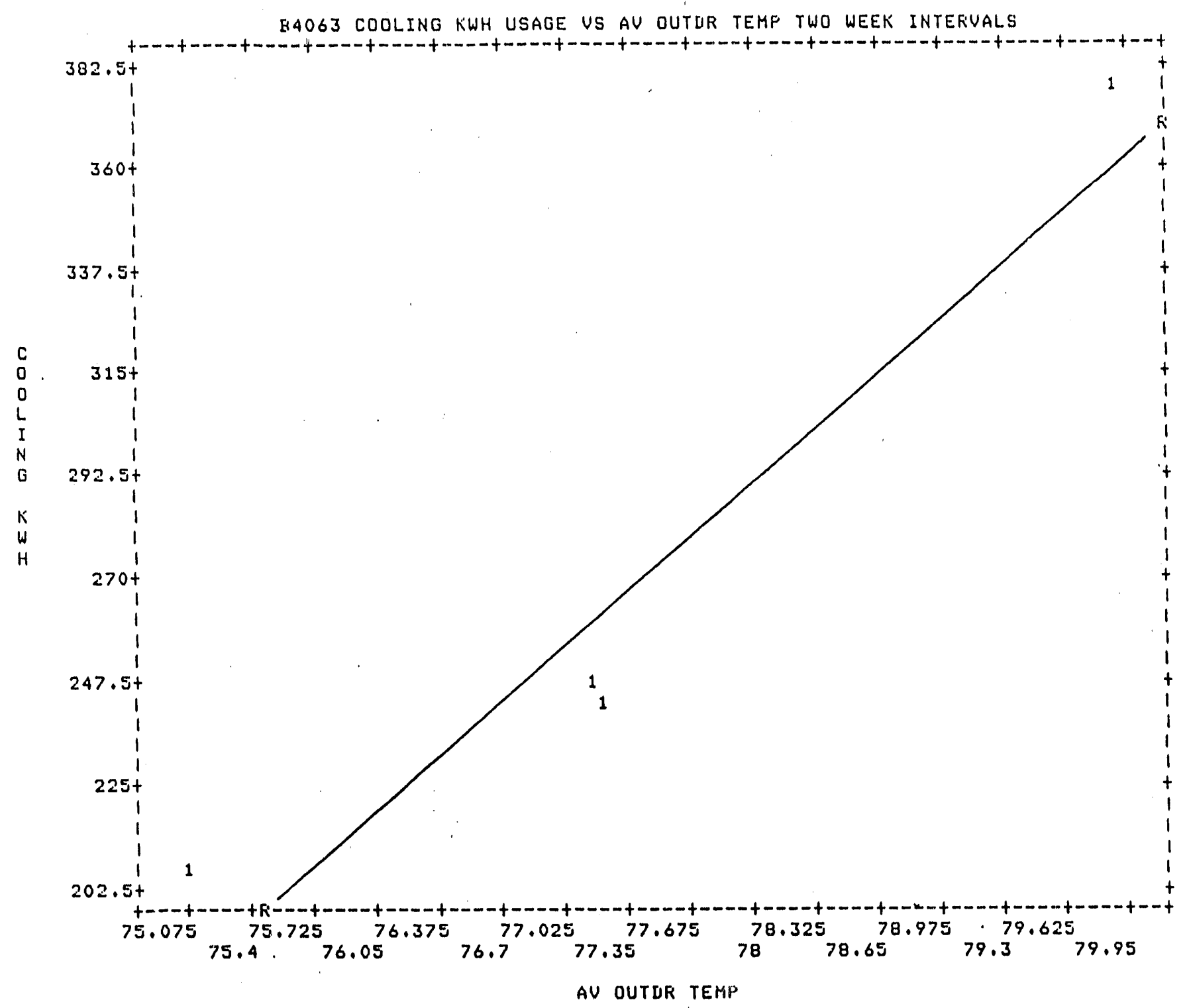

Figure 38 Typical Unit B Cooling Usage vs Average Outdoor Dry Bulb Temperature for Two-Week Intervals 
a typical B unit (\# 4063). Table 5 summarizes the results for the B unit. Although not presented, the results of other units were similar to those of Units A and B. From the Tables it is evident that for short time periods the cooling usage correlated best with cooling degree hours and worst with cooling degree days. As the time period is lengthened, the usage data correlation improves with each of the climatic parameters.

$\underline{T A B L E} \underline{4}$

COOLING USAGE OF UNIT A (\#3928) FOR VARIOUS

TIME INTERVALS AND CLIMATIC PARAMETERS

Time Interval C1imatic Parameter R

$\begin{array}{lll}4 \text { DAY } & \text { CLDHR } & 0.87298 \\ 4 \text { DAY } & \text { CLDD } & 0.50941 \\ 4 \text { DAY } & \text { AVT } & 0.79503 \\ 1 \text { WEEK } & \text { CLDHR } & 0.88356 \\ 1 \text { WEEK } & \text { CLDD } & 0.77003 \\ 1 \text { WEEK } & \text { AVT } & 0.87175 \\ 2 \text { WEEK } & \text { CLDHR } & 0.89089 \\ 2 \text { WEEK } & \text { CLDD } & 0.9789 \\ 2 \text { WEEK } & \text { AVT } & 0.97536\end{array}$


$\underline{\text { TABLE }} \underline{5}$

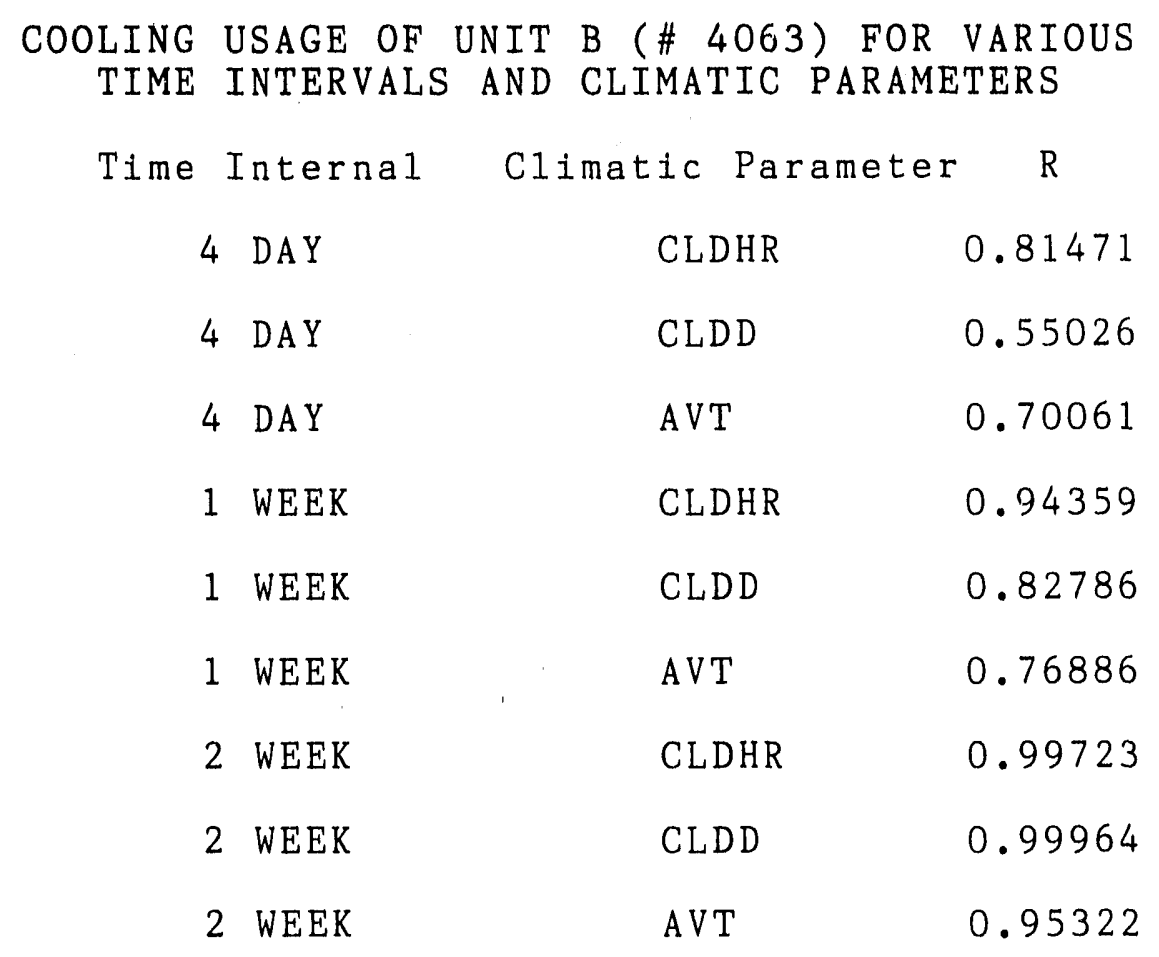

Cumulative Cooling Energy Usage for A Cooling Season

In order to predict the energy used for cooling of a given structure, a cumulative degree-hour approach was used, i.e. an initial starting date was selected near the beginning of a cooling season, and the cooling-degree hours and corresponding house KWH usage were calculated for selected successive dates. Scatter plots were made for cooling KWH usage versus cooling degree-hours. Overlay plots for six A Units, twelve B Units, five C Units and twelve Heritage Units are presented in Figures 39 through 42. The correlation 
COOLING KWH USAGE US COOLING IIEGREE HOUR'S

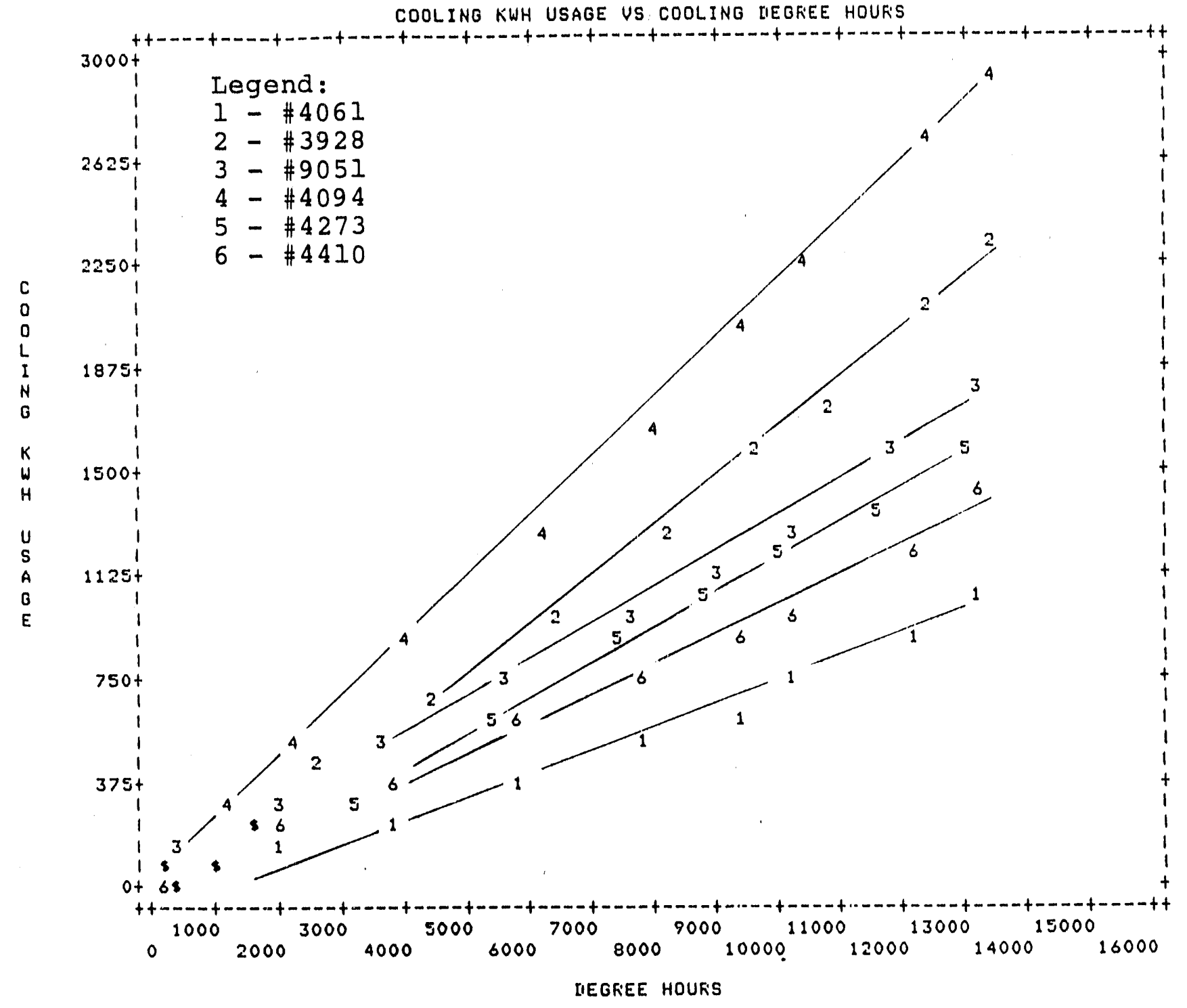

Figure 39 Cumulative Couling Energy Usage vs Cooling

Degree-Hours for Various Individual A Units 


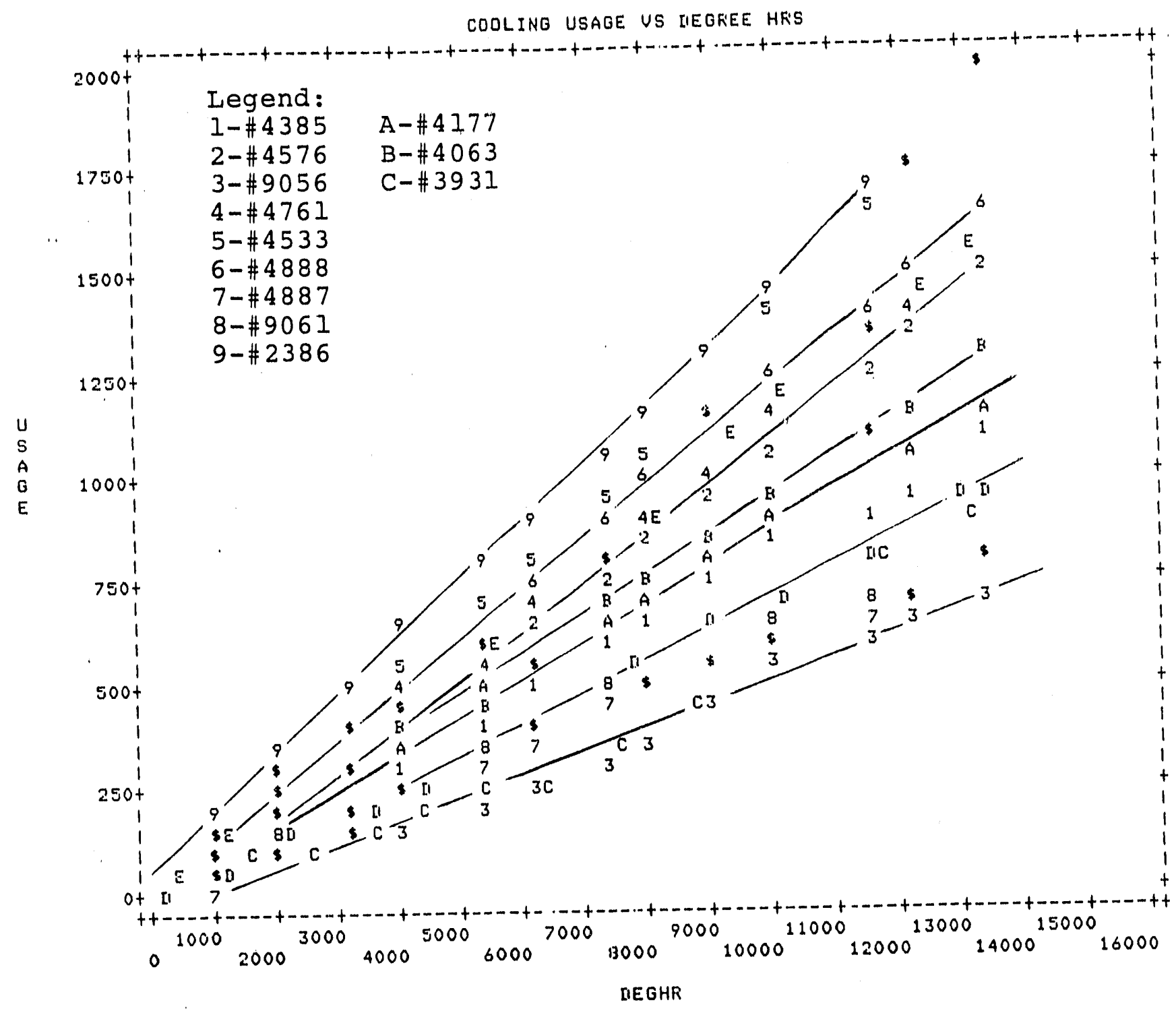

Figure 40 Cumulative Cooling Energy Usage vs Cooling Degree-Hours for Various Individual B Units 


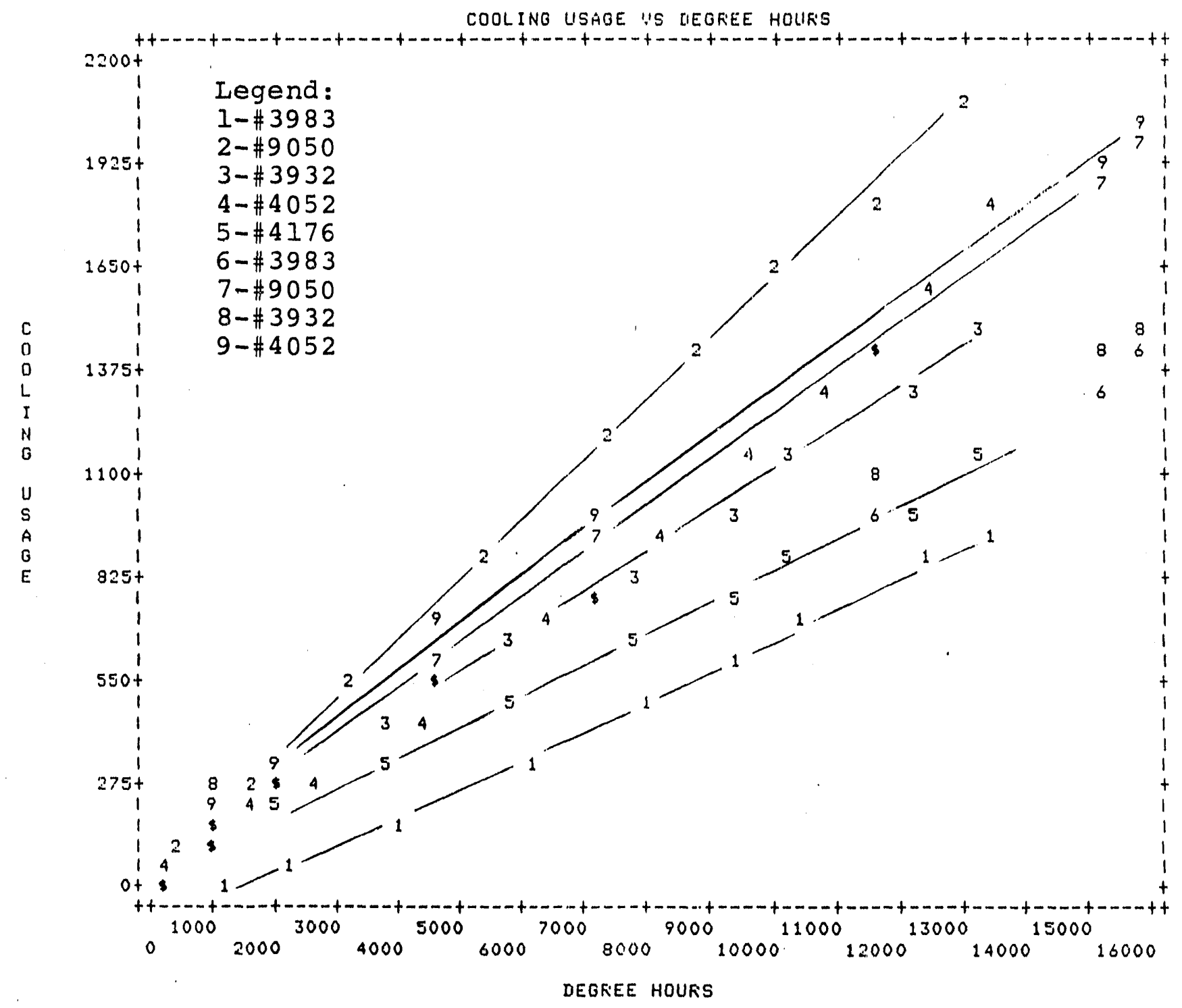

Figure 41 Cumulative Cooling Energy Usage vs Cooling Degree-Hours for Various Individual C Units 
COOLING KWH USAGE US, COOLING DIEGREE HCURS

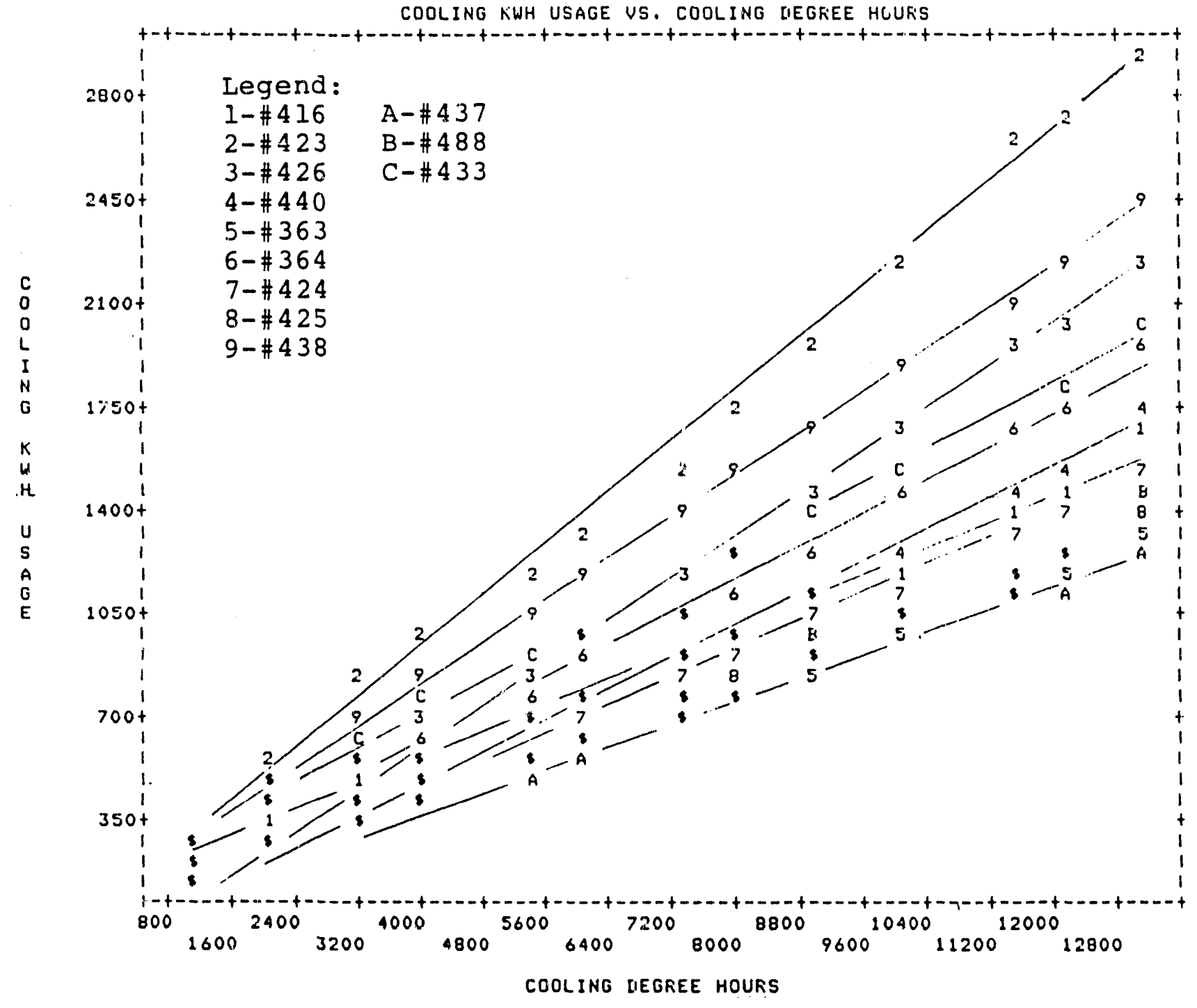

\footnotetext{
Figure 42 Cumulative Cooling Energy Usage vs Cooling Degree-Hou:s for Various Individual

Herftage Square Units
} 
coefficients for each corresponding individual unit are presented in Table 6. The correlation coefficients for all cases investigated were greater than 0.96000 , indicating that this approach could possibly be used for predicting the cooling energy usage for a given number of cumulative degreehours. In order to investigate this approach farther, cooling data for 1986 were obtained and compared for selected cases against 1985 data. An overlay plot for an A Unit (\#3928) is presented in Figure 43. Figure 44 presents the scatter plot and regression analysis for the A Unit for 1985 and 1986. The correlation coefficient is 0.98910 . Figures 45 through 50 present the corresponding data for a B Unit, C Unit and Heritage Square house. 
COOLING KWH USAGE US CLG LIR:G HISS

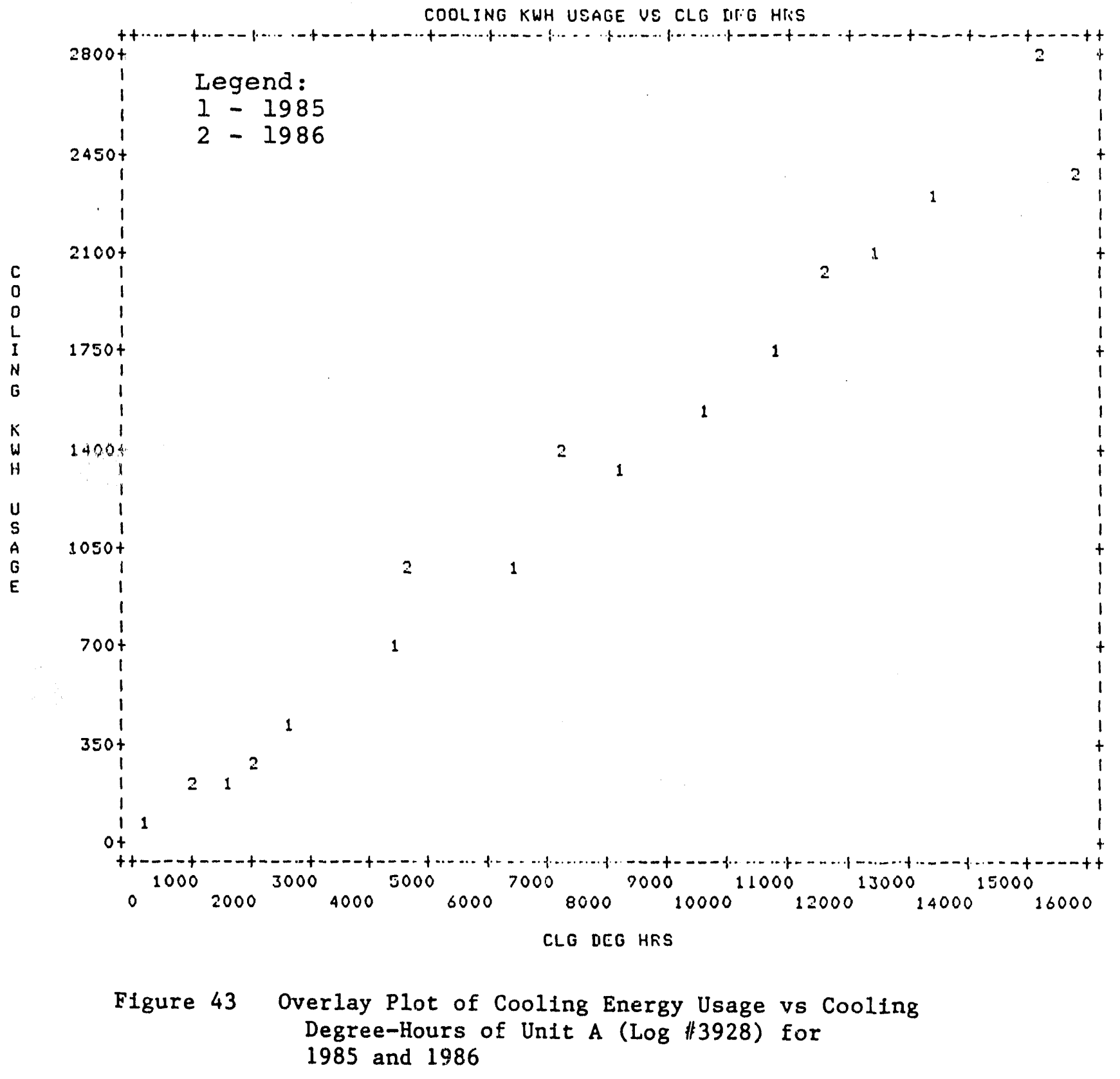




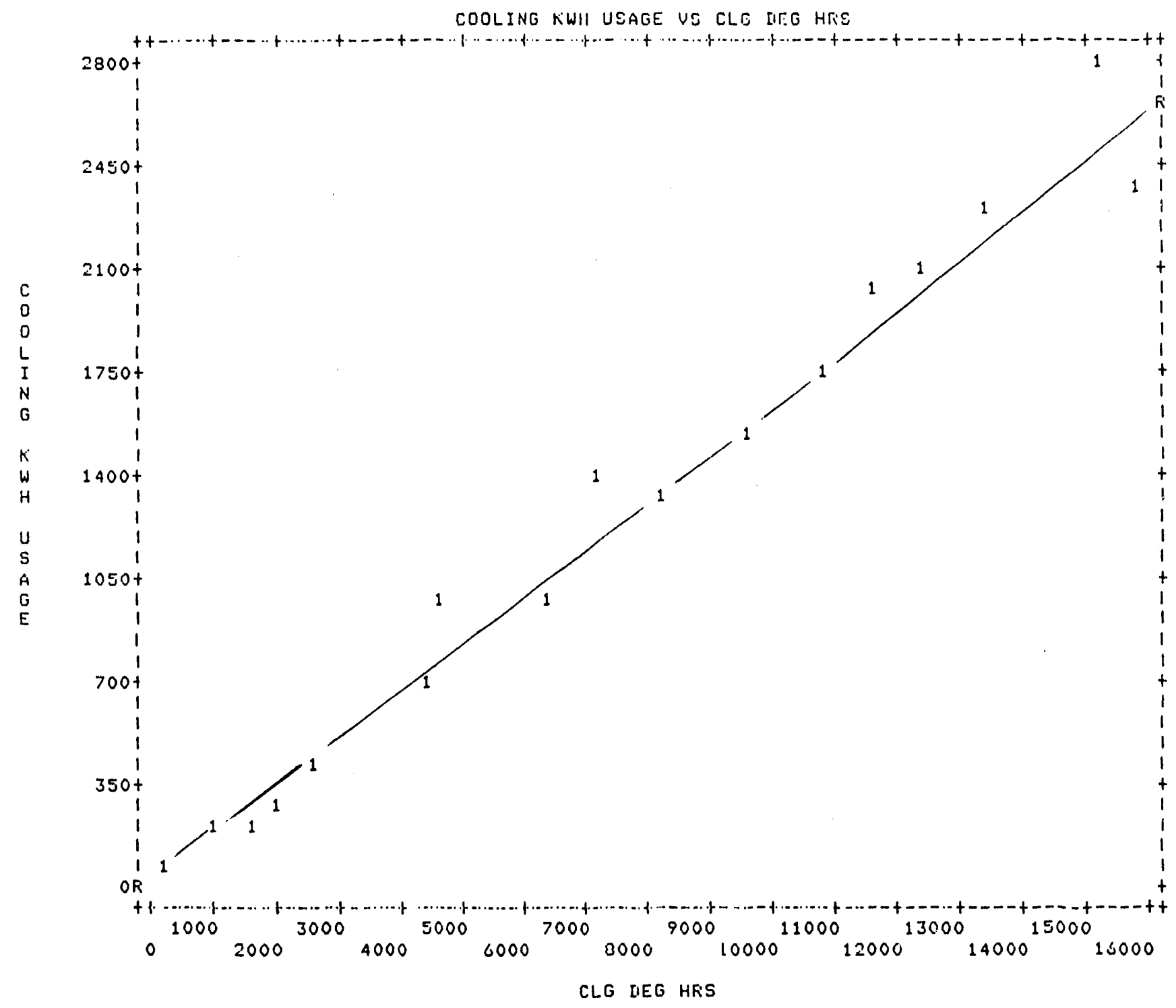

Figure 44 Regression Plot of Cooling Energy Usage vs Cooling Degree-Hours of Unft A (Log \#3928) 
COOLING KWH USAGE US CLG IIEG HFIS

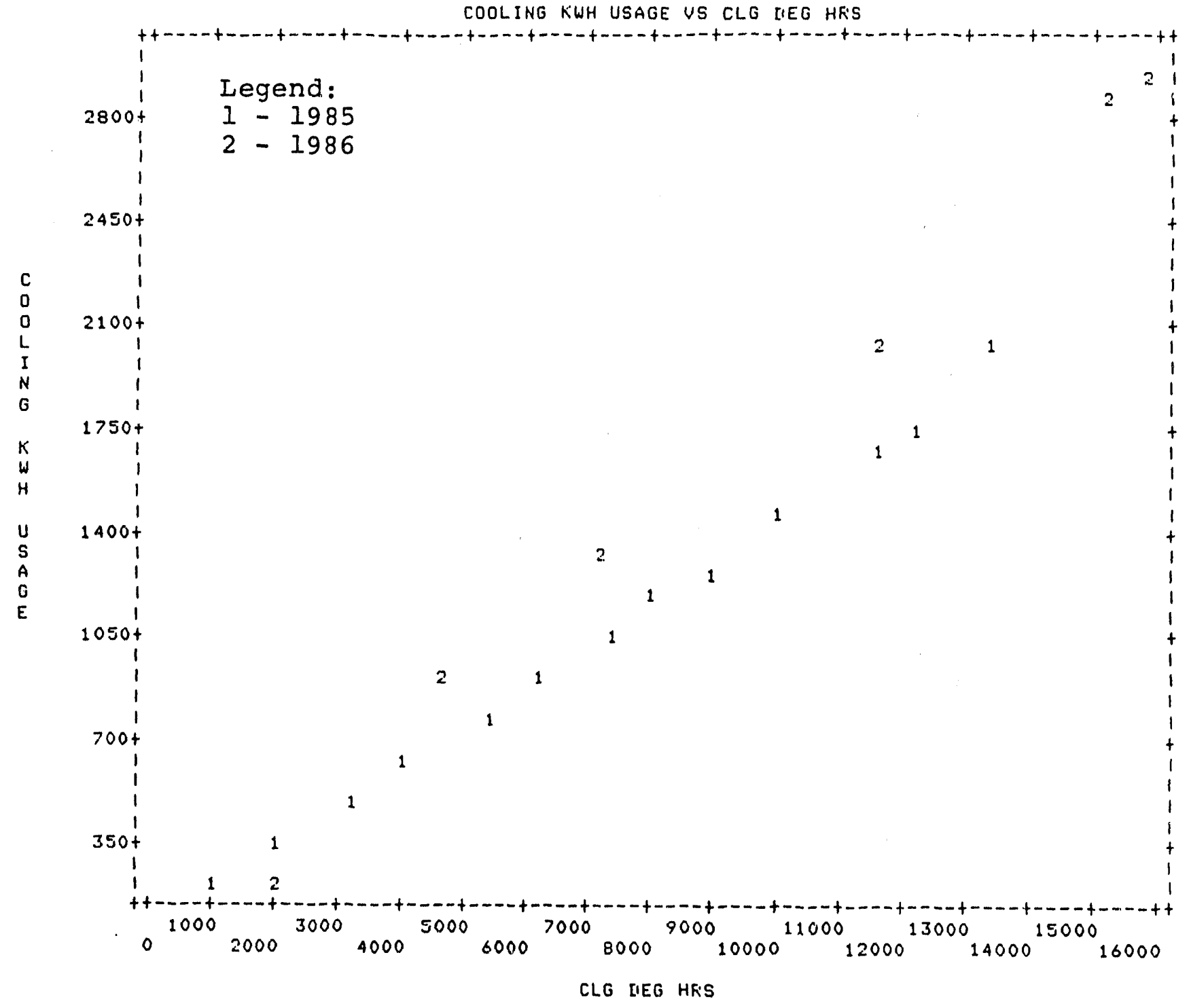

Figure 45 Overlay Plot of Cooling Energy Usage vs Cooling Degree-Hours of Un1t B ( Log \#2386) for 1985 and 1986 


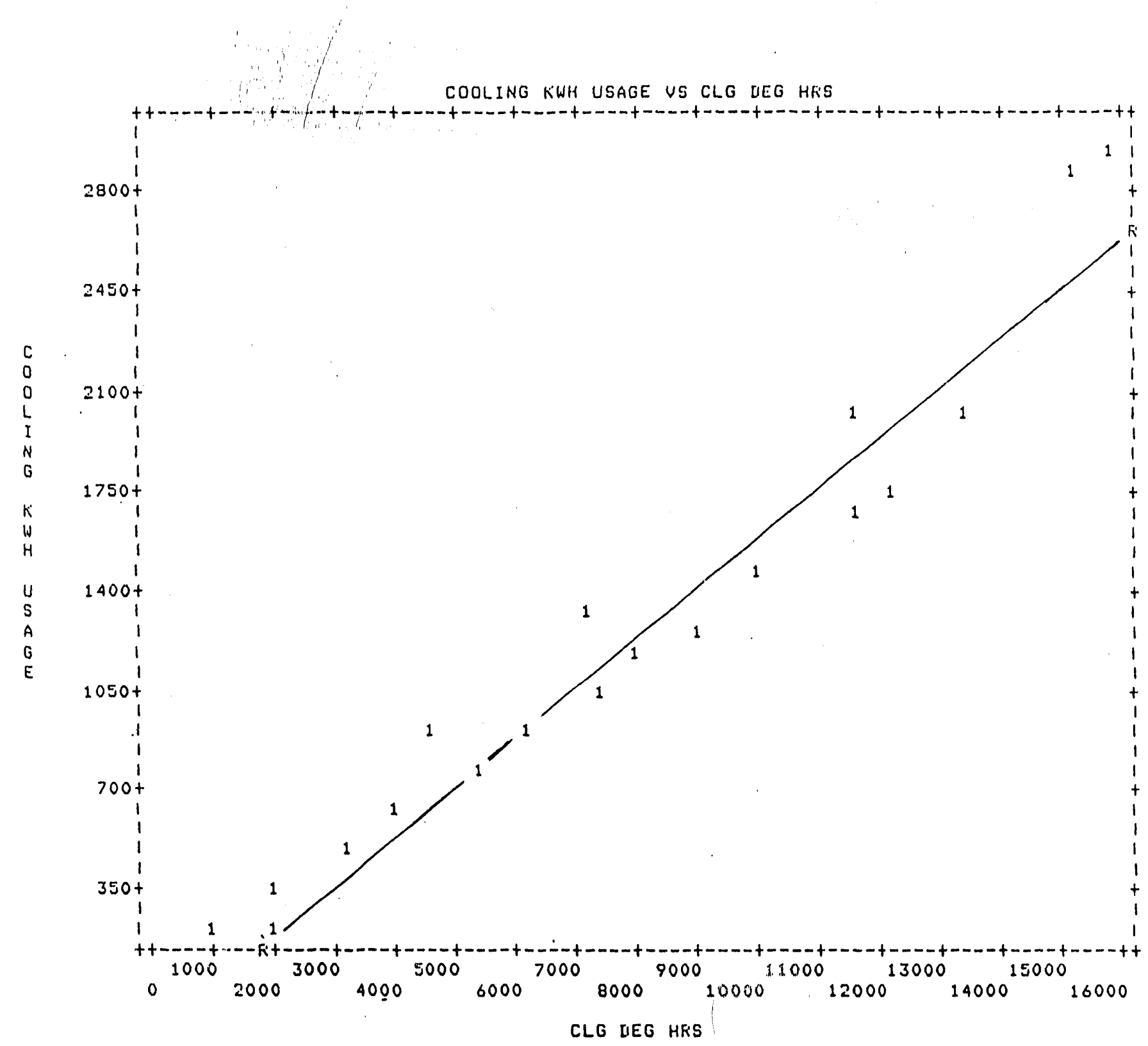

Figure 46 Regression Plot of Cooling Energy Usage vs Cooling Degree-Hours of Unit B (Log \#2386) 
COOLING KWH USAGE US CLG IIEG HRS

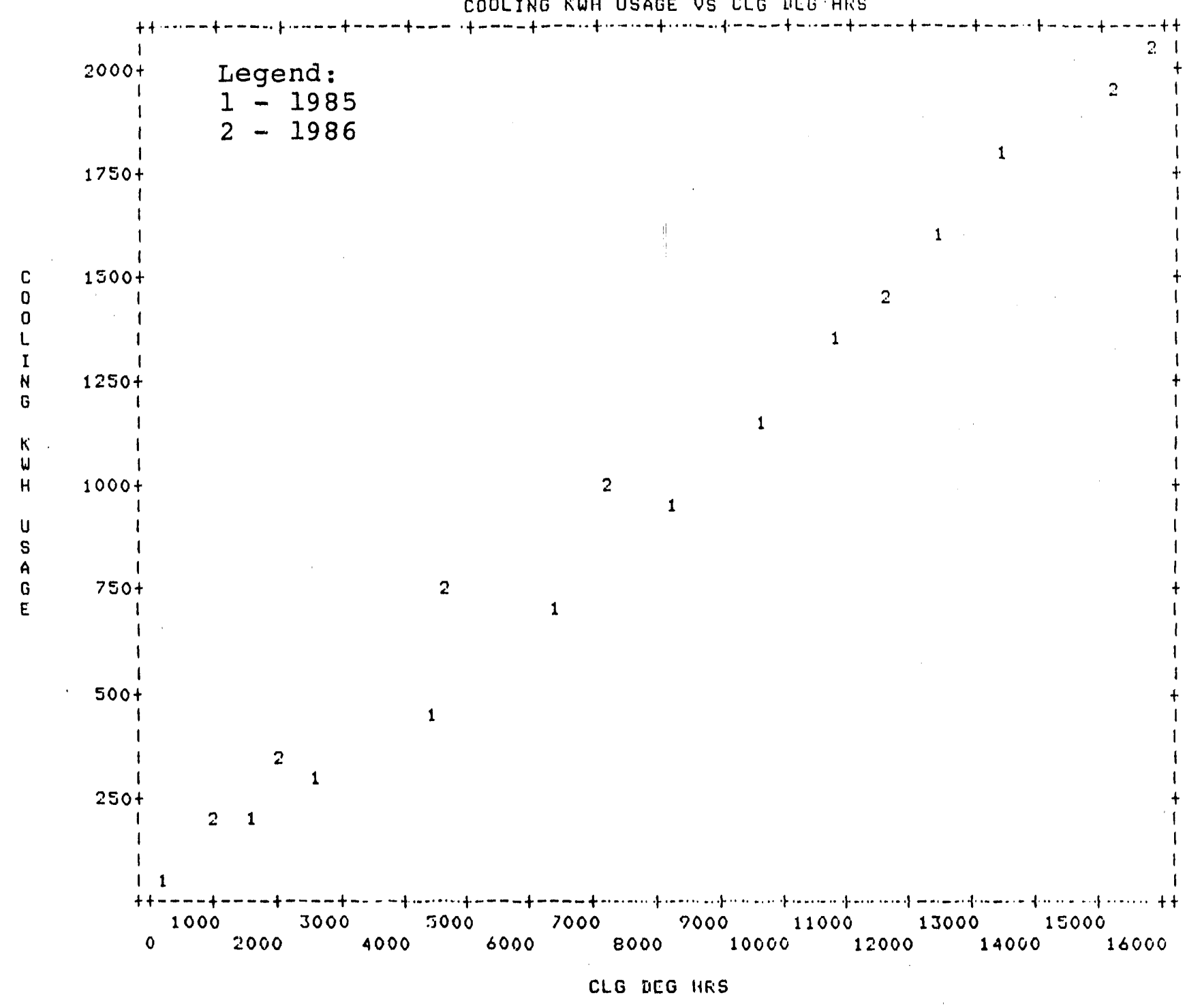

Figure 47 Overlay Plot of Cooling Energy Usage vs

Cooling Degree-Hours of Unit C (Log \#4052)

for 1985 and 1986 


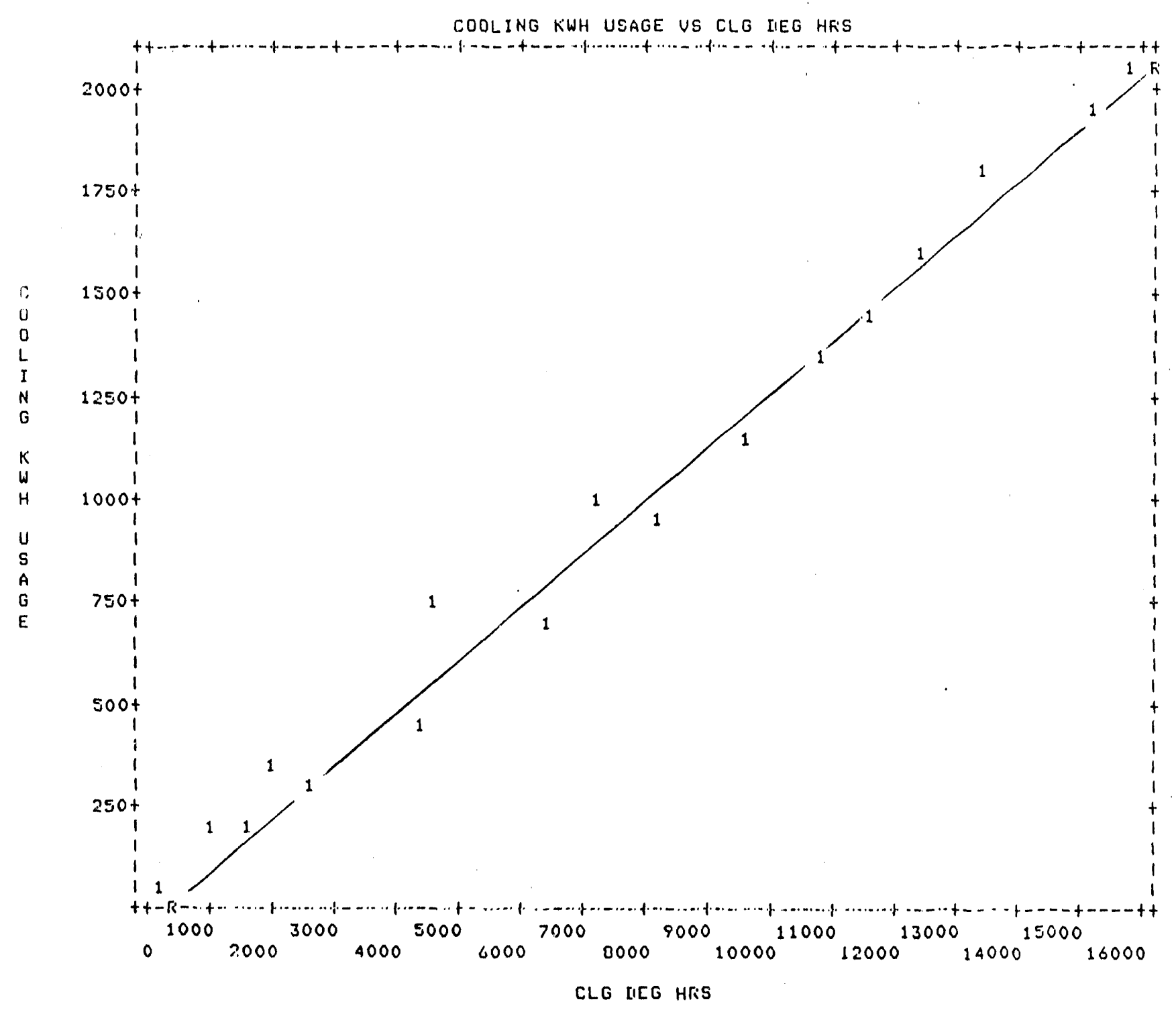

Figure 48 Regression Plot of Cooling Energy Usage vs Cooling Degree-Hours of Unit C (Log \#4052) for 1985 and 1986 
COOLING KWH USAOE US CLG IIFG HIS

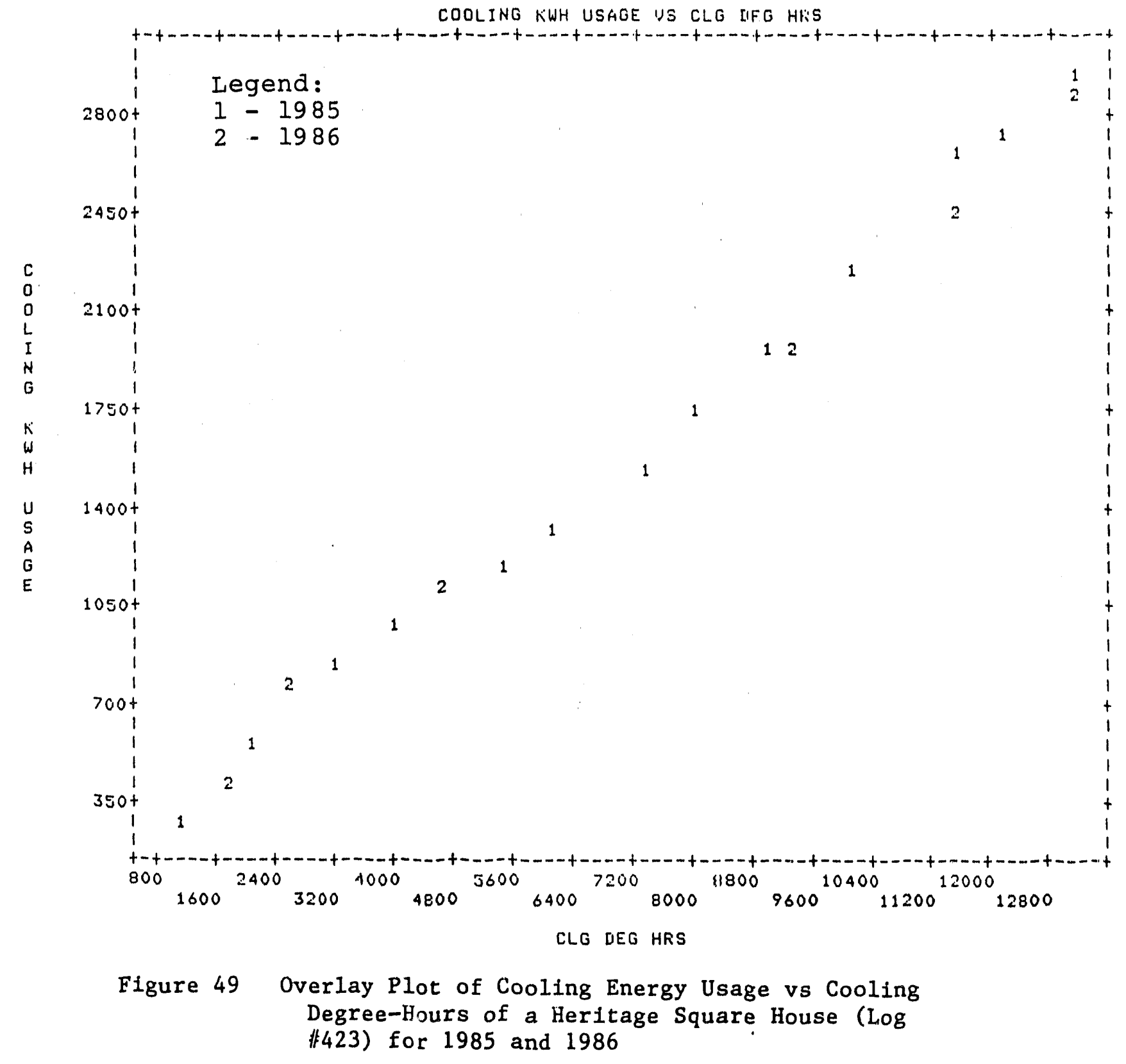




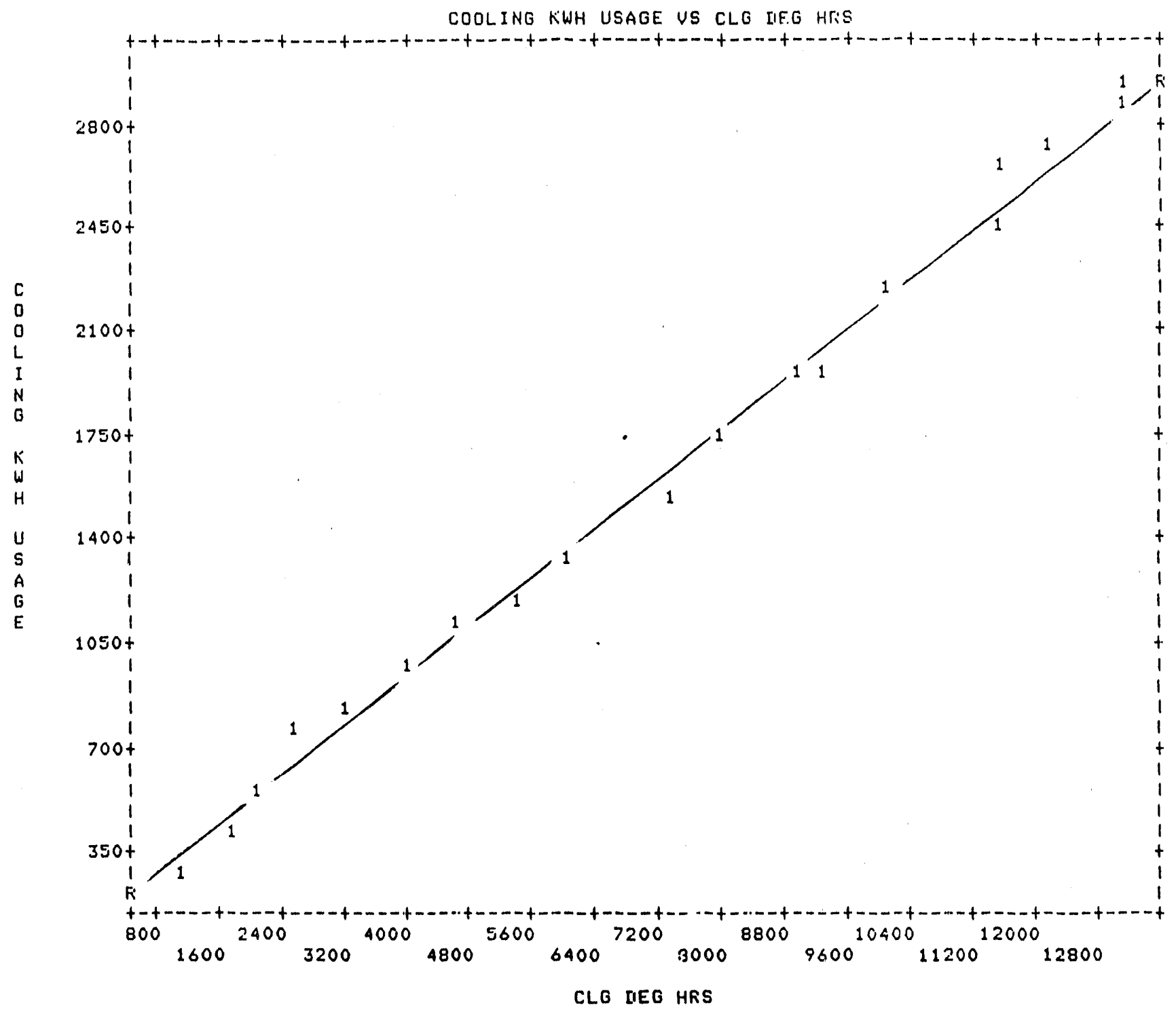

Figure 50 Regression Plot of Cooling Energy Usage vs Cooling Degree-Hours of a Heritage Square House (Log $\# 423$ ) for 1985 and 1986 
$\underline{\text { TABLE }} \underline{6}$

CORRELATION OF STRUCTURE COOLING ENERGY USAGE WITH CUMULATIVE COOLING DEGREE- HOURS

(JUNE 14,1985 TO SEPTEMBER 26, 1985)

\begin{tabular}{|c|c|c|c|c|}
\hline & UNIT & $\mathrm{R}$ & UNIT & $\mathrm{R}$ \\
\hline $\begin{array}{l}A \\
A\end{array}$ & $\begin{array}{l}4061 \\
3928 \\
9051 \\
4094 \\
4273\end{array}$ & $\begin{array}{l}0.99257 \\
0.99831 \\
0.99685 \\
0.99906 \\
0.99944\end{array}$ & $\begin{array}{ll}C & 3983 \\
C & 9050 \\
C & 3932 \\
C & 4052 \\
C & 4176\end{array}$ & $\begin{array}{l}0.99480 \\
0.99980 \\
0.99847 \\
0.99239 \\
0.99927\end{array}$ \\
\hline $\begin{array}{l}\text { A } \\
B \\
B \\
B \\
B \\
B\end{array}$ & $\begin{array}{l}4410 \\
4385 \\
4576 \\
9056 \\
4761\end{array}$ & $\begin{array}{l}0.99870 \\
0.99743 \\
0.99796 \\
0.98310 \\
0.99489\end{array}$ & $\begin{array}{ll}\mathrm{H} & 416 \\
\mathrm{H} & 423 \\
\mathrm{H} & 426 \\
\mathrm{H} & 440 \\
\mathrm{H} & 363\end{array}$ & $\begin{array}{l}0.99768 \\
0.99809 \\
0.99751 \\
0.99840 \\
0.99837\end{array}$ \\
\hline $\begin{array}{l}B \\
B\end{array}$ & $\begin{array}{l}4533 \\
4888 \\
4887 \\
9061 \\
2386\end{array}$ & $\begin{array}{l}0.99550 \\
0.99930 \\
0.99518 \\
0.99737 \\
0.99906\end{array}$ & $\begin{array}{ll}\mathrm{H} & 364 \\
\mathrm{H} & 424 \\
\mathrm{H} & 425 \\
\mathrm{H} & 438 \\
\mathrm{H} & 437\end{array}$ & $\begin{array}{l}0.99839 \\
0.96714 \\
0.99793 \\
0.99924 \\
0.99505\end{array}$ \\
\hline B & $\begin{array}{l}4177 \\
4063 \\
3931\end{array}$ & $\begin{array}{l}0.99750 \\
0.99871 \\
0.96942\end{array}$ & $\begin{array}{ll}\mathrm{H} & 488 \\
\mathrm{H} & 433\end{array}$ & $\begin{array}{l}0.99592 \\
0.99800\end{array}$ \\
\hline
\end{tabular}

Table 7 summarizes the results.

\section{TABLE 7}

CORRELATION OF STRUCTURE COOLING ENERGY USAGE WITH CUMULATIVE COOLING DEGREE-HOURS FOR 1985 AND 1986

UNIT

$\mathrm{R}$
A 3928
0.98910
B 2386
0.97430
C 4052
0.99221
H 423
0.99740 
From these analyses, it seems reasonable to conclude that if the cooling energy usage vs cooling degree-hours graph is known for a given structure, then one may predict the cooling usage if the cooling degree hours are known during a specified cooling period.

The possibility that the HVAC usage could also be a function of the latent heat load due to infiltration was examined. This portion of the total HVAC load did not appear to great 1 y effect the usage. Since great care was taken during construction to minimize infiltration, it should have been expected perhaps that latent effects would be negligible. In older, loosely constructed houses, this component may be significant.

If one examines Figures 39 through 42 , it is noted that the cooling usage characteristics vary great 1 y among units of identical floor plans. Differences in the slopes of the HVAC energy use vs cooling degree-hour curves for identical units, can possibly be attributed to a variation in thermostat setting, equipment efficiency, and/or the design cooling load itself. In order to obtain average values of cooling energy usage for specific house designs, SPSSx regrossion analyses were performed for the units under study. Figures 51 through 54 present the scatter plots and Table 8 summarizes the results. 


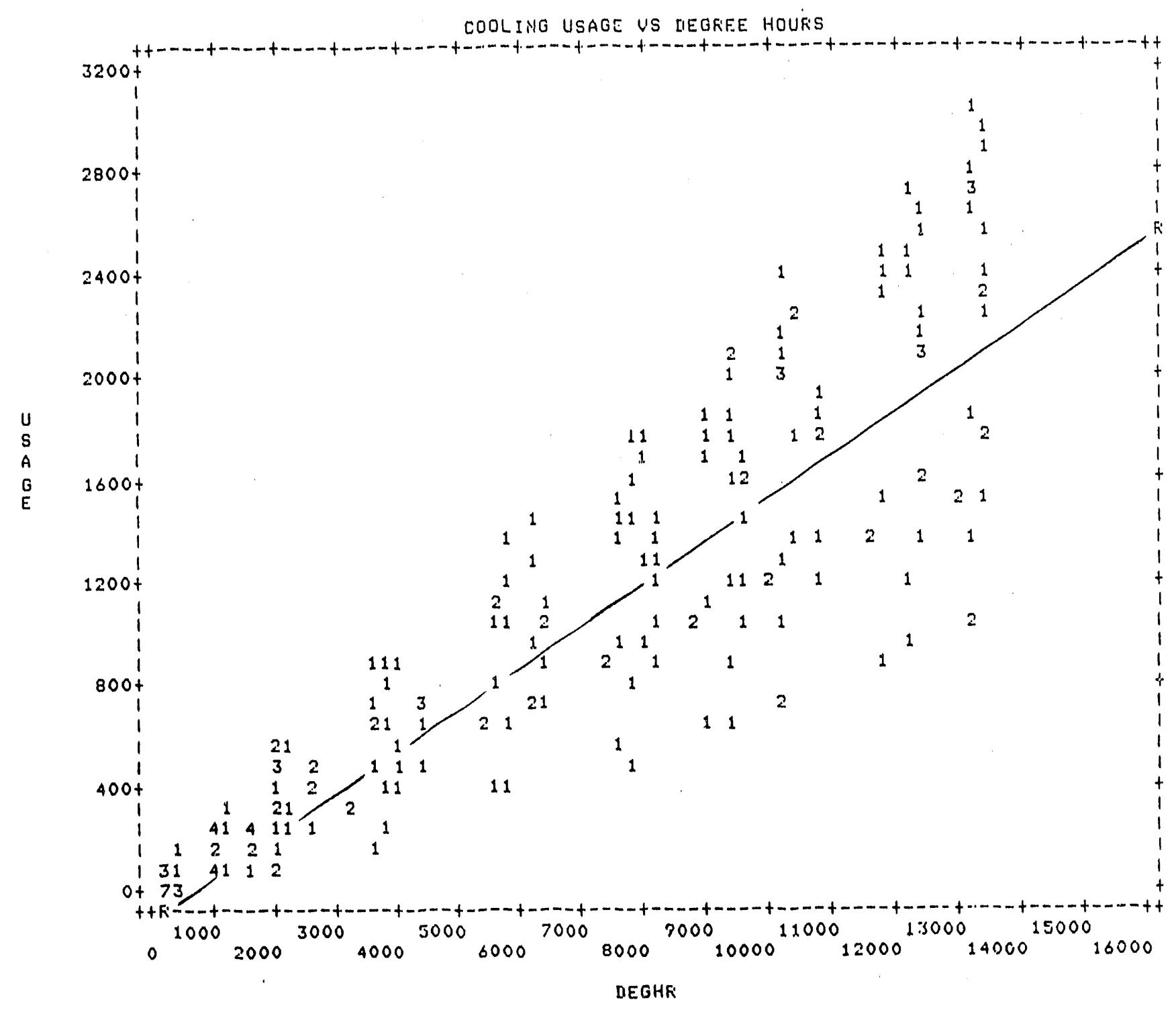

Figure 51 Cumulative Cooling Energy Usage vs Cooling Degree-Hours for A Units 


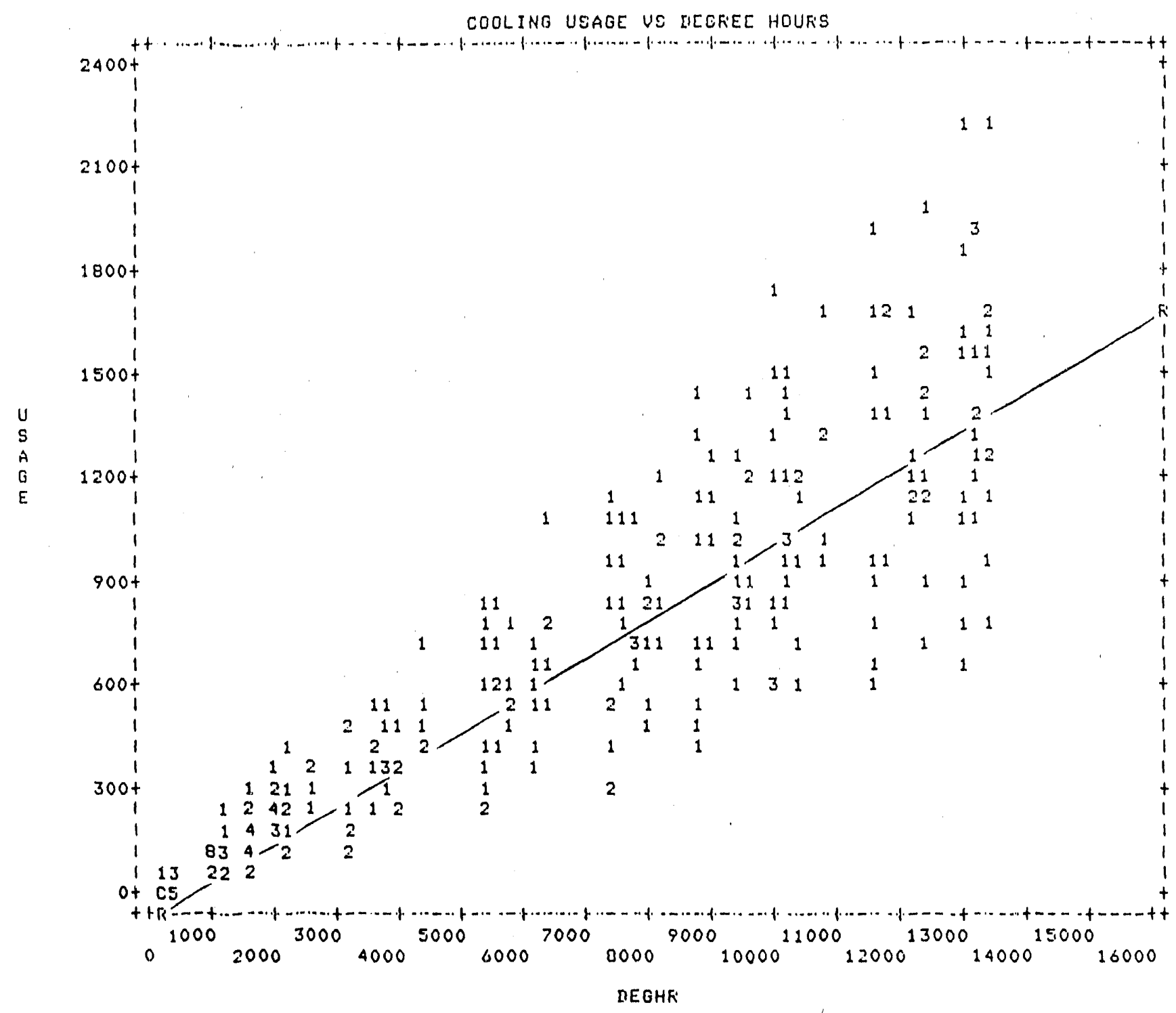

Figure 52 Cumulative Cooling Energy Usage vs Cooling Degree-Hours for B. Units 


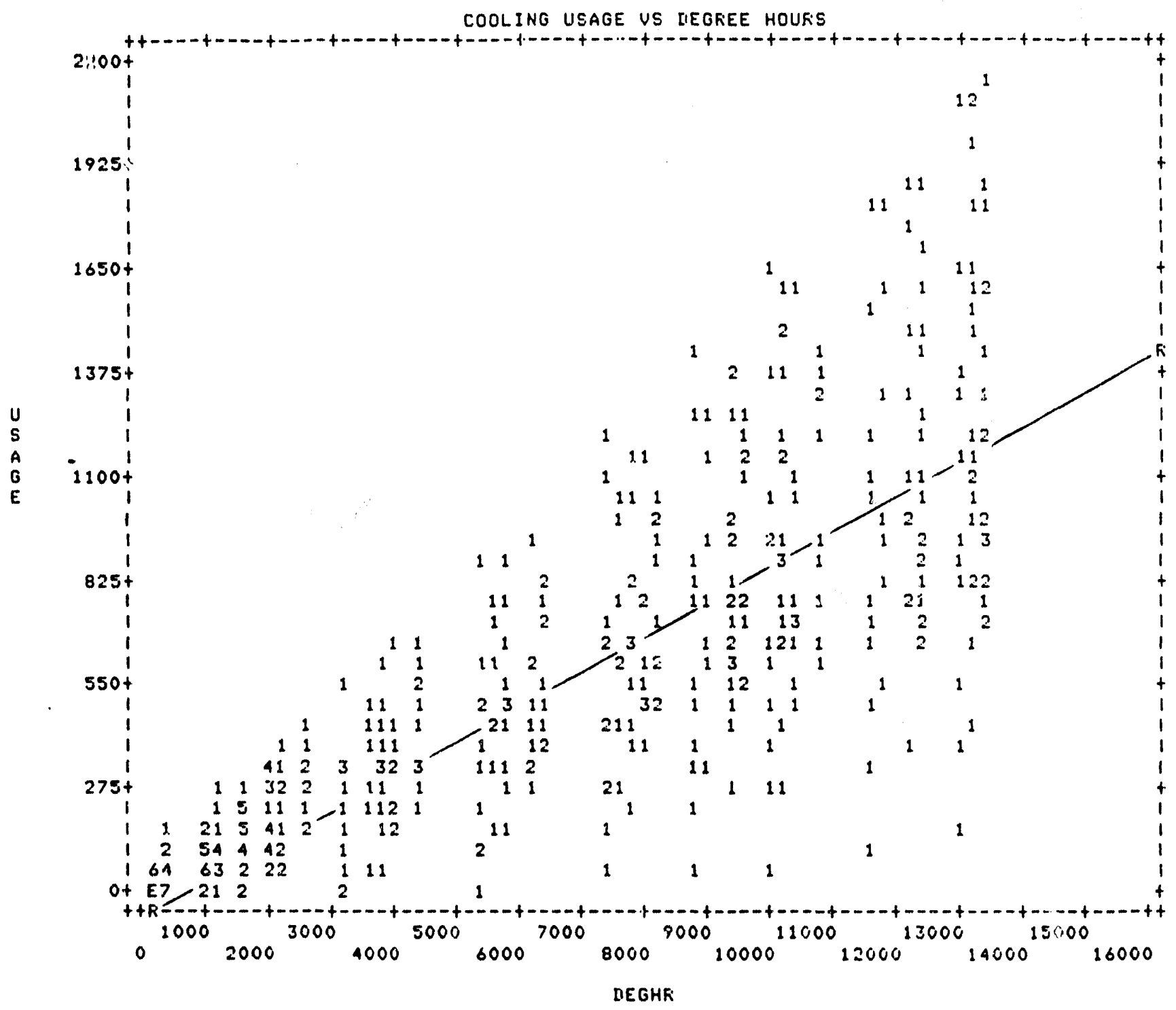

Figure 53 Cumulative Cooling Energy Usage vs Cooling Degree-Hours for C Units 


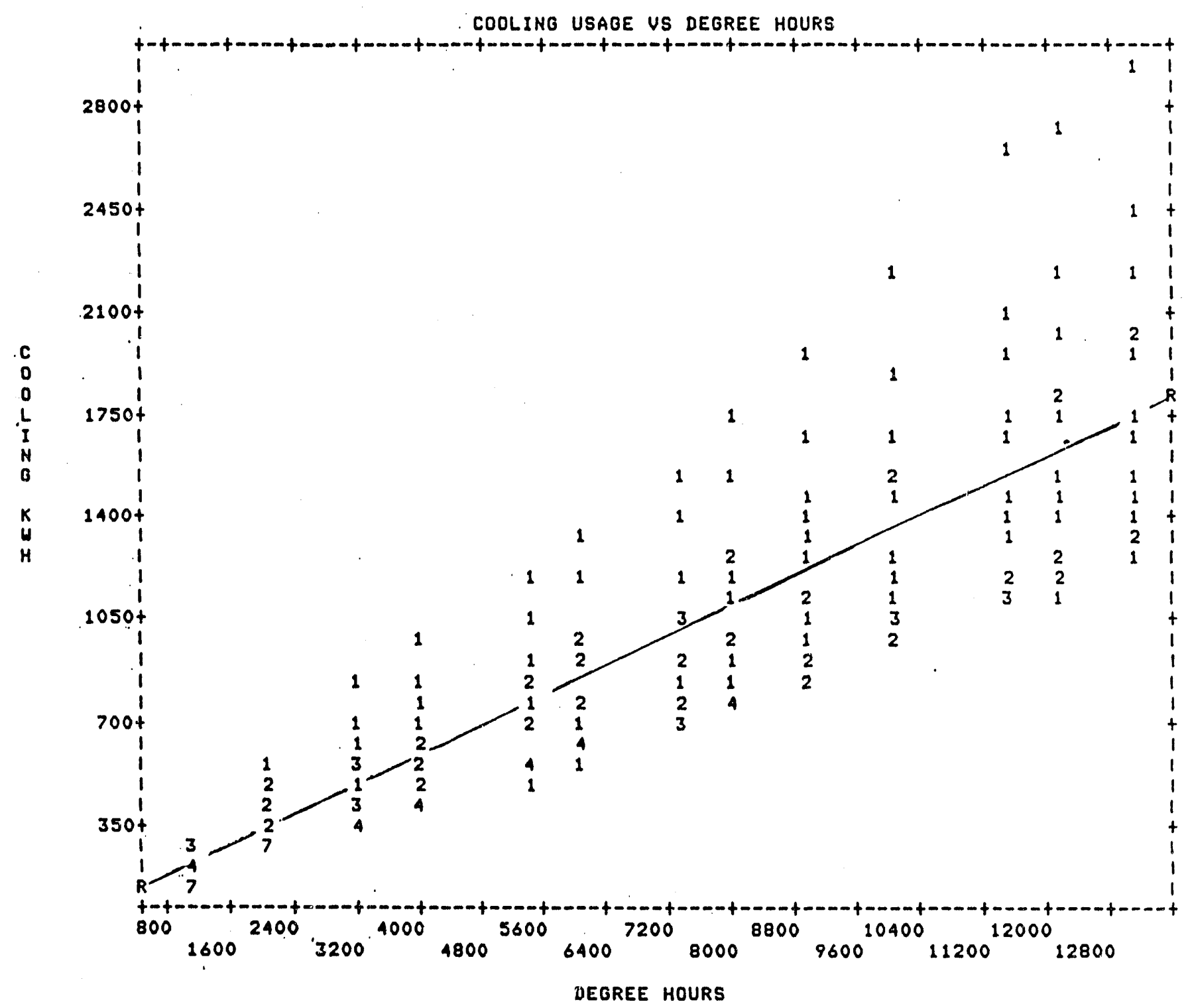

Figure 54 Cumulacive Cooling Energy Usage vs Cooling Degree-Hcurs for Heritage Square Units 


\section{$\underline{\text { TABLE }} \underline{8}$}

COOLING ENERGY USAGE vS COOLING DEGREE-HOURS for VARIOUS HOUSE DESIGNS

Unit

$\mathrm{R}$

Regression Equation

A $\quad 0.87940 \quad \mathrm{KWH}=0.16168 \mathrm{CLDHR}-30.472$

B $\quad 0.88028$

$\mathrm{KWH}=0.10628 \mathrm{CLDHR}-15.1799$

C $\quad 0.79234$

$\mathrm{KWH}=0.08910 \mathrm{CLDHR}-10.8762$

Heritage 0.85260

$\mathrm{KWH}=0.12930$ CLDHR -60.68

Comparison with Cooling Energy Usage Models

Several formulae have been proposed to predict cooling energy usage. A "gross method" and bin hours method are presented in the Manual J, Seventh Edition (2).

These two approaches will be compared to the cooling degreehour method. The following symbols will be used and are herewith defined:

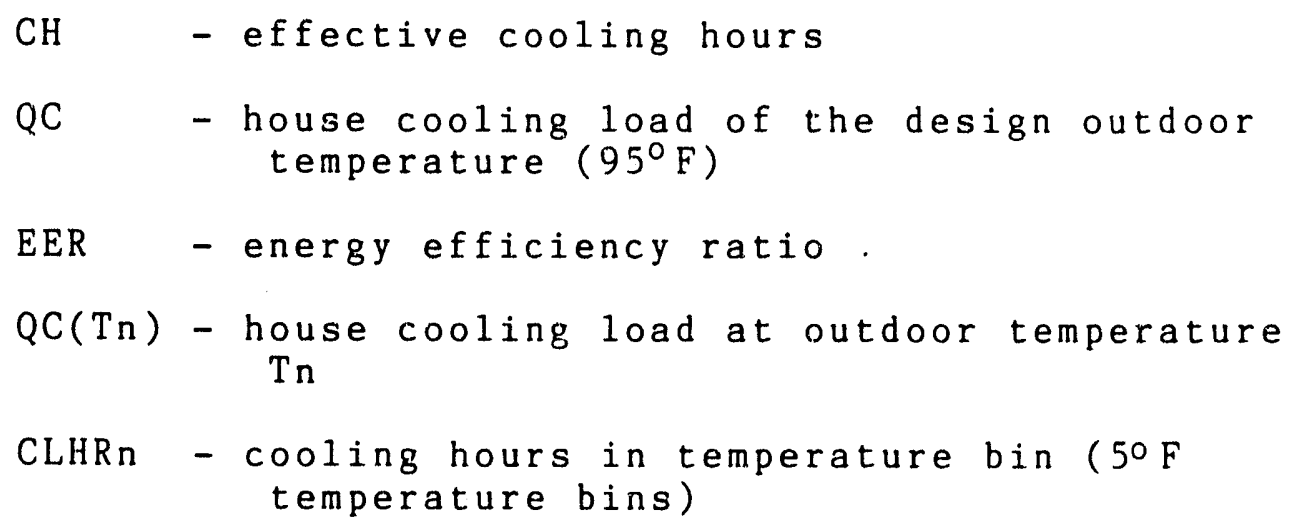




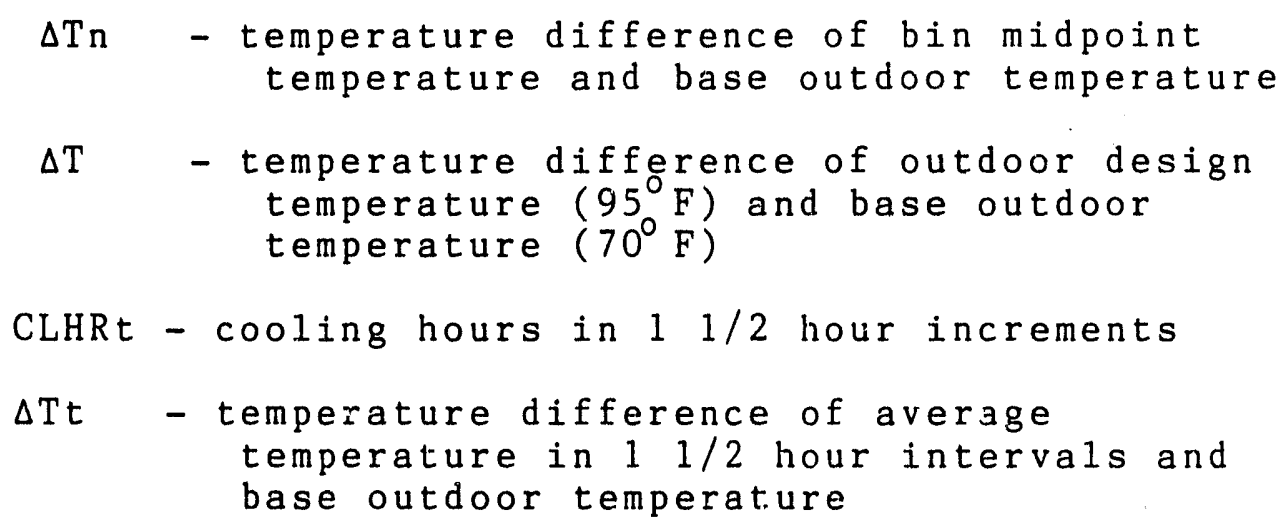

The "gross method" may be stated numerically as:

Gross Method HVAC Usage $=(\mathrm{CH} * \mathrm{QC}) /(1000 * \mathrm{EER})$

(Manual J) (KWH)

The Bin Method utilizing $5^{\circ} \mathrm{F}$ bins is:

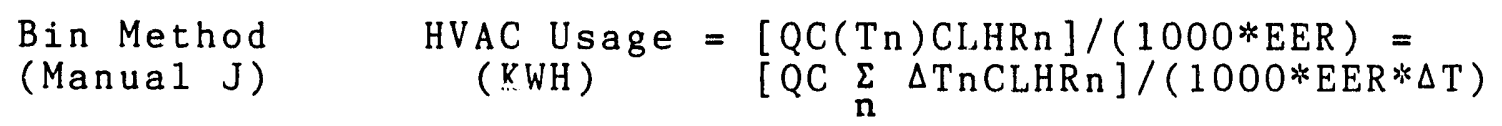

The Cooling Degree Hour Method used in this study is:

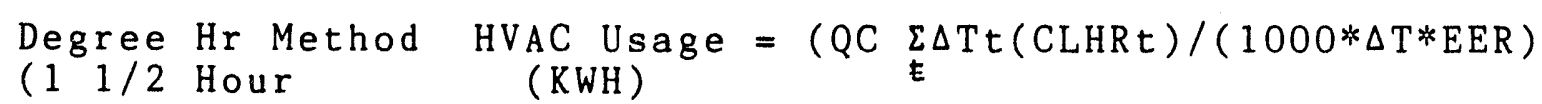

Intervals )

These equations may be rearranged in terms of effective cooling hours for a more simplified comparison:

$\begin{array}{ll}\text { Gross Method } & \mathrm{CH}=(\mathrm{KWH} * 1000 * \mathrm{EER}) /(\mathrm{QC}) \\ \text { Bin Method } & \mathrm{CH}=(\mathrm{KWH} * 1000 * \mathrm{EER}) /(\mathrm{QC})=\left(\sum_{\mathrm{n}} \Delta \mathrm{TnCLHRn}\right) / \Delta \mathrm{T} \\ \text { Degree Hr Method } & \mathrm{CH}=(\mathrm{KWH} 1000 * \mathrm{EER}) /(\mathrm{QC})=\left(\sum_{\mathrm{t}} \Delta \mathrm{TtCLHRt}\right) / \Delta \mathrm{T}\end{array}$

For the dates June 17,1985 to August 23, 1985 and for a base temperature of $70^{\circ} \mathrm{F}$ and an outdoor design temperature of $95^{\circ} \mathrm{F}$, the number of hours that the temperature exceeded $70^{\circ} \mathrm{F}$ 
was 1386. The number of cooling degree hours based on $5^{\circ} \mathrm{F}$ temperature bins was 14190 degree-hours. The number of cooling degree hours based on $11 / 2$ hour intervals was 13147 degree-hours. Thus a comparison of the models yields:

$\begin{array}{llrl}\text { Gross Method } & \mathrm{CH}=1386 \text { hrs } & \% \text { difference } & 164 \\ \text { Bin Method } & \mathrm{CH}=14190 / \Delta \mathrm{T}=567.6 \text { hrs } \% \text { difference } & 8 \\ \begin{array}{l}\text { Degree Hr } \\ \text { Method }\end{array} & \mathrm{CH}=13147 / \Delta \mathrm{T}=525.9 \text { hrs } \% \text { difference } & 0\end{array}$

It appears for the 1985 cooling period that the "gross method" will over predict the cooling usage by a factor of 1.6 while the bin and degree-hour methods are within reasonable agreement. One should note that only calculated climatic conditions have been used to compare the models. If one wants to actually predict the cooling usage over a time period, the cooling load, thermostat setting, base temperature, and occupant behavior in addition to weather conditions must be considered. This variation in usage for identical floor plans has been previously presented in Figures 39 through 42 . 
CHAPTER V

COMPARISON OF PRESENT DATA WITH OTHER STUDIES

The Nashville Electric Service collected data from its service area in which cooling and heating usages were obtained for houses in the 1000 to $1800 \mathrm{sq}$. ft. range. The houses varied in age and construction but were heated and cooled with heat pump systems.

Overlay plots are presented in Figure 55 and an expanded scale in Figure 56 for HVAC heating usage per degree day vs house size. It is obvious that houses built with this study's energy package have greatly reduced heating kwh usage. Specifically, the reduction for various house sizes are presented in Table 9.

\section{TABLE 9}

COMPARISON OF HEATING ENERGY USAGE FOR CONVENTIONALLY BUILT AND CONTROLLED CONSTRUCTION HOUSES

$\begin{array}{lccc}\begin{array}{l}\text { House } \\ \text { Size }\end{array} & \begin{array}{c}\text { Controlled } \\ \text { Construction } \\ \text { Sq Ft }\end{array} & \begin{array}{c}\text { Conventional } \\ \text { House } \\ \text { Kow KWH/DD }\end{array} & \begin{array}{c}\text { \% Energy } \\ \text { Usage } \\ \text { Reduction }\end{array} \\ 1000 & 1.34 & 1.58 & 15.6 \\ 1200 & 1.48 & 1.99 & 25.6 \\ 1400 & 1.62 & 2.38 & 31.8\end{array}$


TABLE 9 (cont.)

COMPARISON OF HEATING ENERGY USAGE FOR CONVENTIONALLY BUILT AND CONTROLLED CONSTRUCTION HOUSES

\begin{tabular}{|c|c|c|c|}
\hline $\begin{array}{l}\text { House } \\
\text { Size } \\
\text { Sq Ft }\end{array}$ & $\begin{array}{l}\text { Controlled } \\
\text { Construction } \\
\text { House KWH/DD }\end{array}$ & $\begin{array}{c}\text { Conventional } \\
\text { House } \\
\text { KWH/DD }\end{array}$ & $\begin{array}{l}\text { \% Energy } \\
\text { Usage } \\
\text { Reduction }\end{array}$ \\
\hline 1600 & 1.76 & 2.57 & 31.5 \\
\hline 1800 & 1.90 & 2.95 & 35.6 \\
\hline
\end{tabular}

The energy usage data set was used to produce cooling energy usage for 134 homes over a seven-year period. "'he SPSSx Information System was again used to produce the scatter plot of Figure 57. The regression equation for cooling usage which yielded a correlation coefficient of 0.72862 is

$$
\text { Cooling KWH }=1.448 \mathrm{SQ}+675.9
$$

Figures 58 and 59 compare the regression curve to cooling data obtained from the Nashville Electric Service. As with heating, the comparison of conventional vs. energy package houses revealed a significant reduction in energy usage. Table 10 summarizes these results. 
HUAC KWH FER IIEGREE IIAY - $95 \%$ CONFI IIENCE EIANI

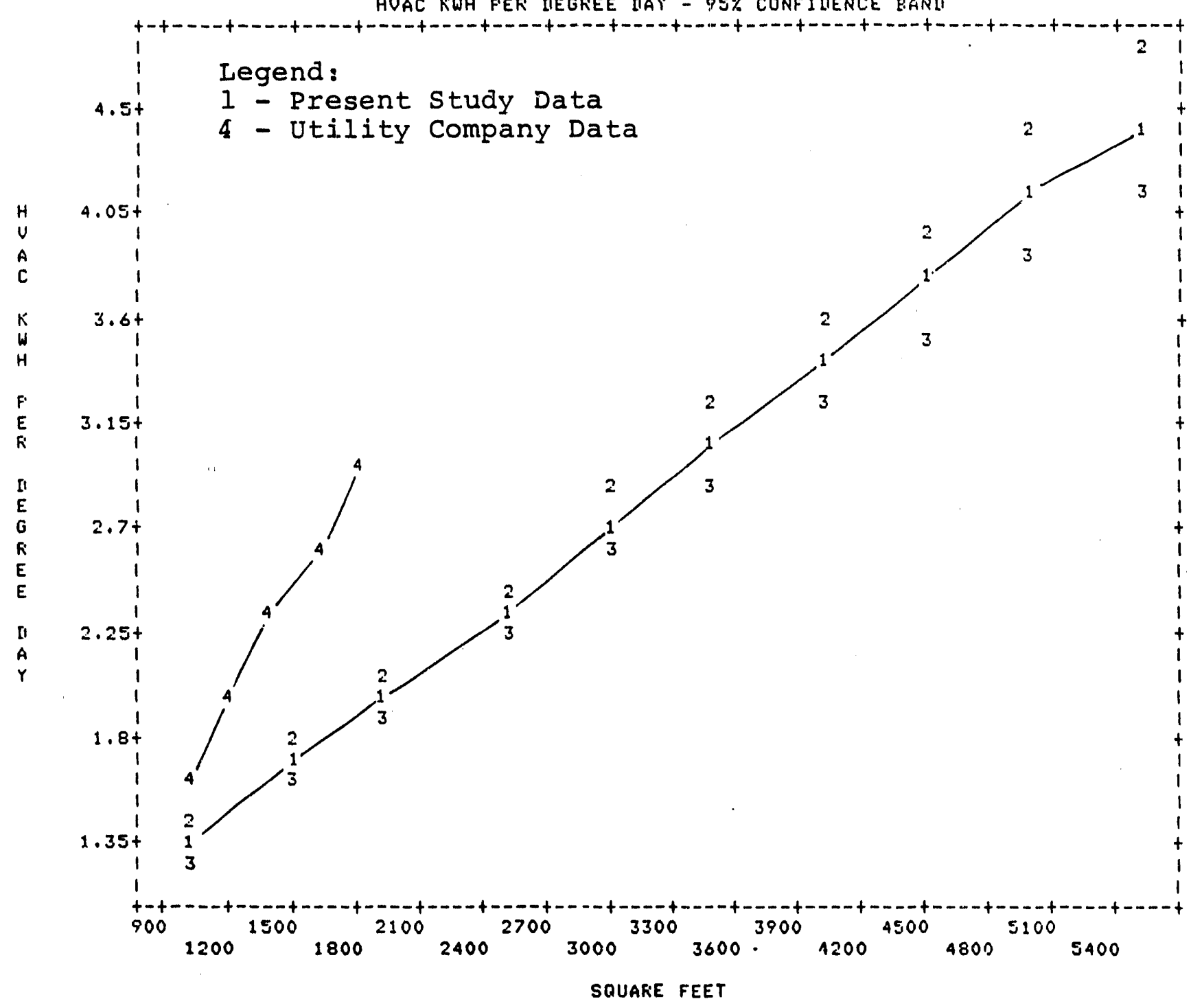

Figure 55 Comparison of Ut1lity Company and Present Study Heating Usage Data vs House Size 


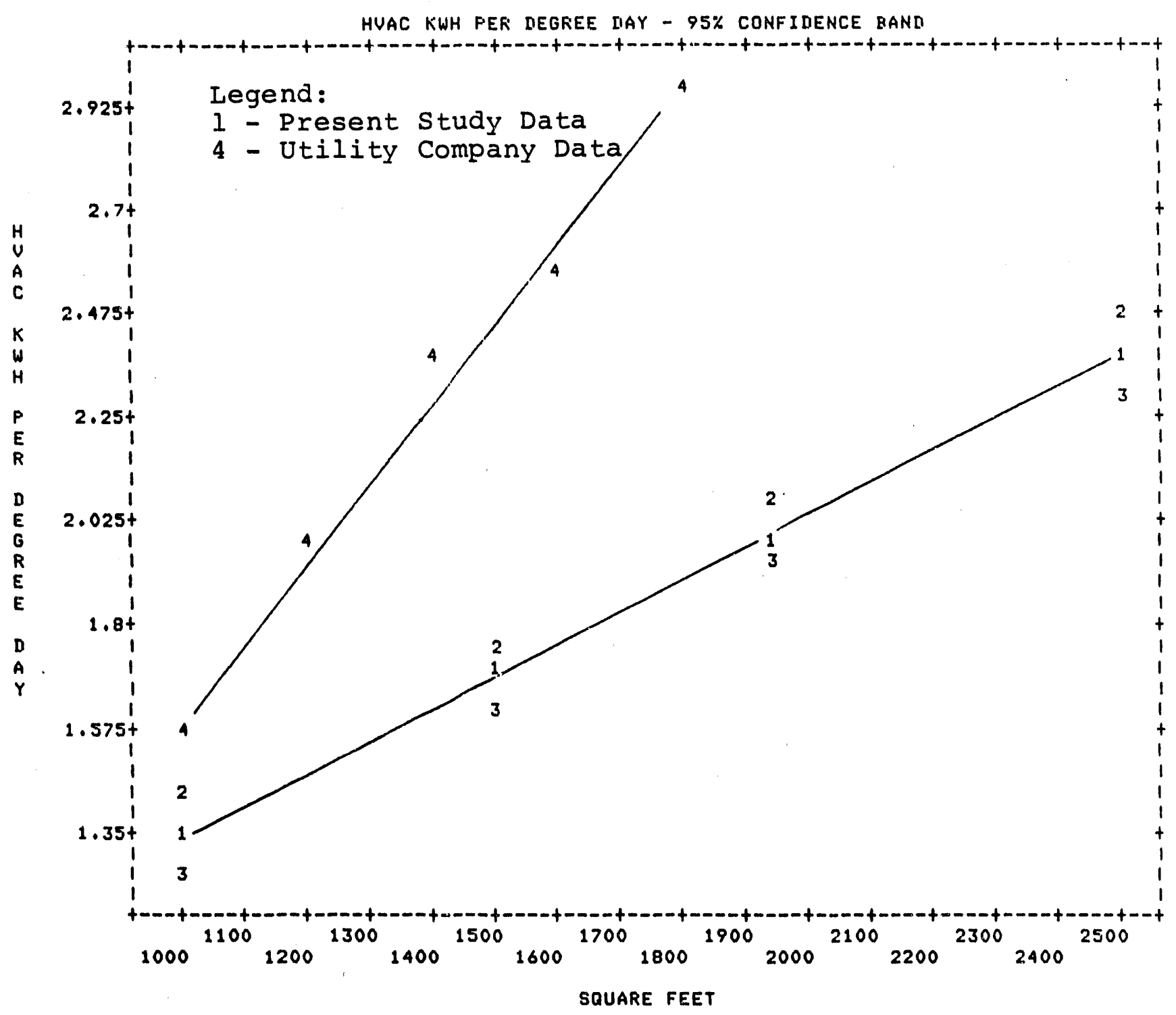

Figure 56 Expanded Scale Comparison of Utility Company and Present Study Heating Usage

Data vs House Size 
COOLING USAGE US HOUSE SQ FOOTAGE

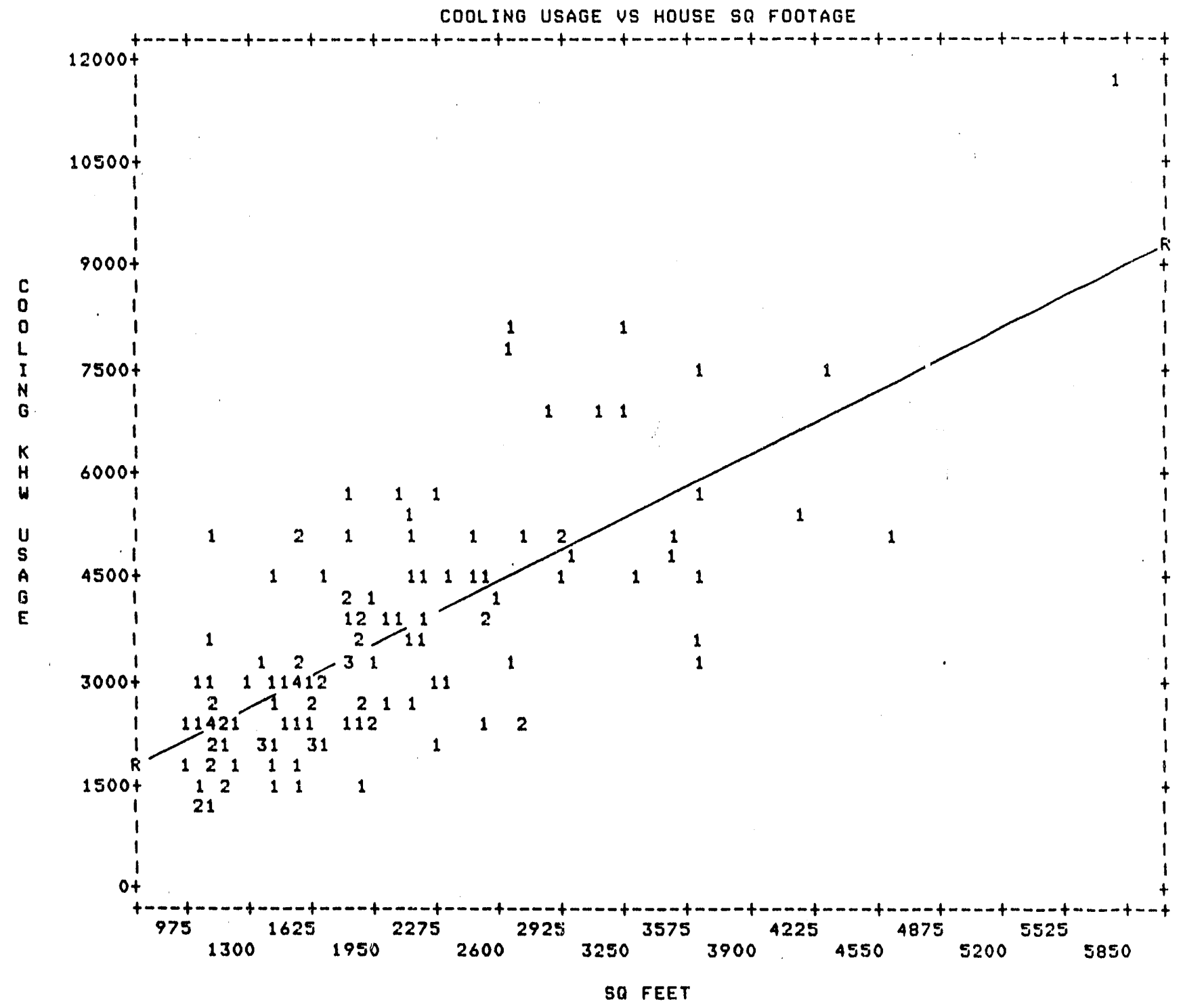

Figure 57 Cooling Energy Usage vs House Size 


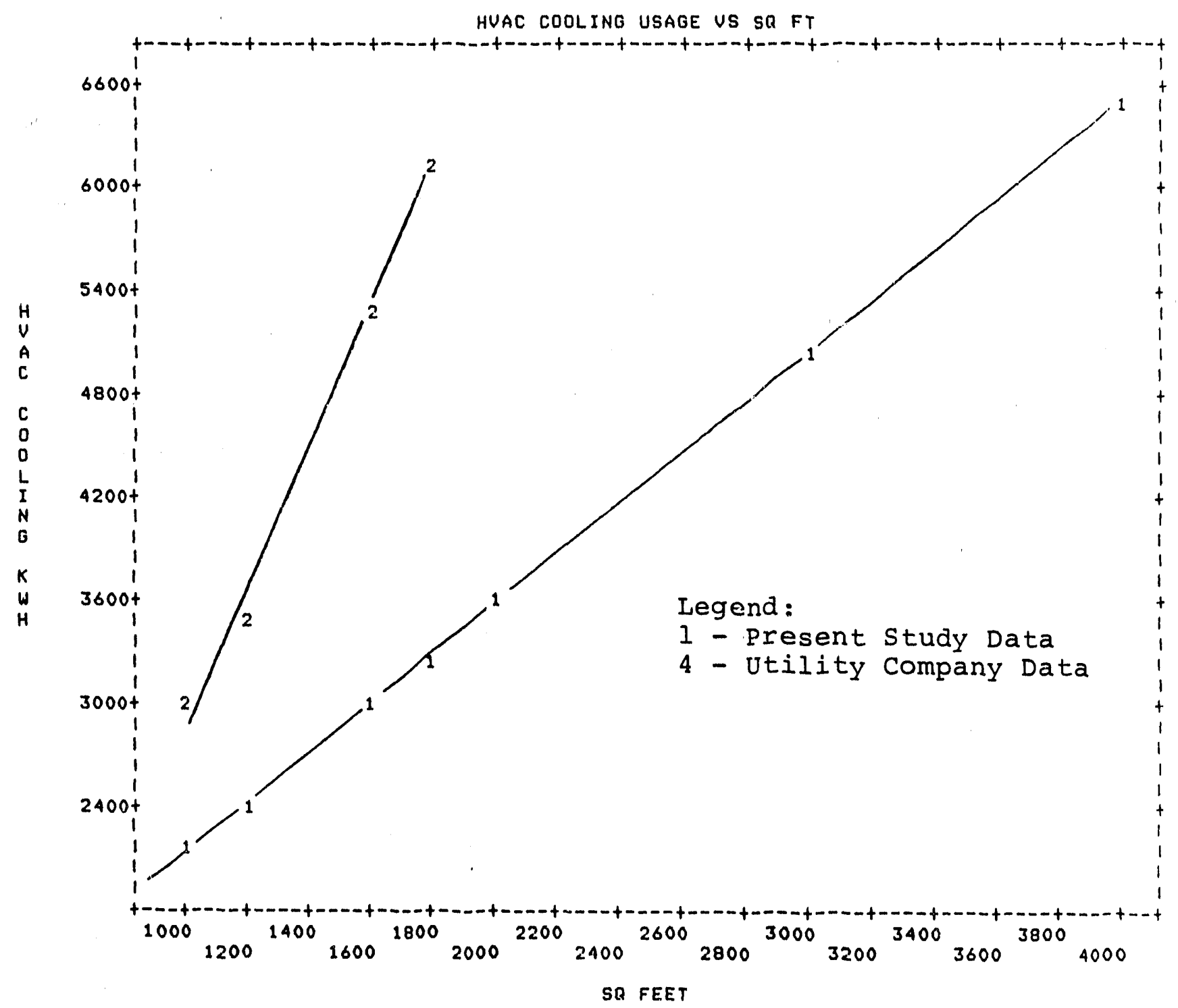

Figure 58 Comparison of Utility Company and Present Study Cooling Usage Data vs House Size 


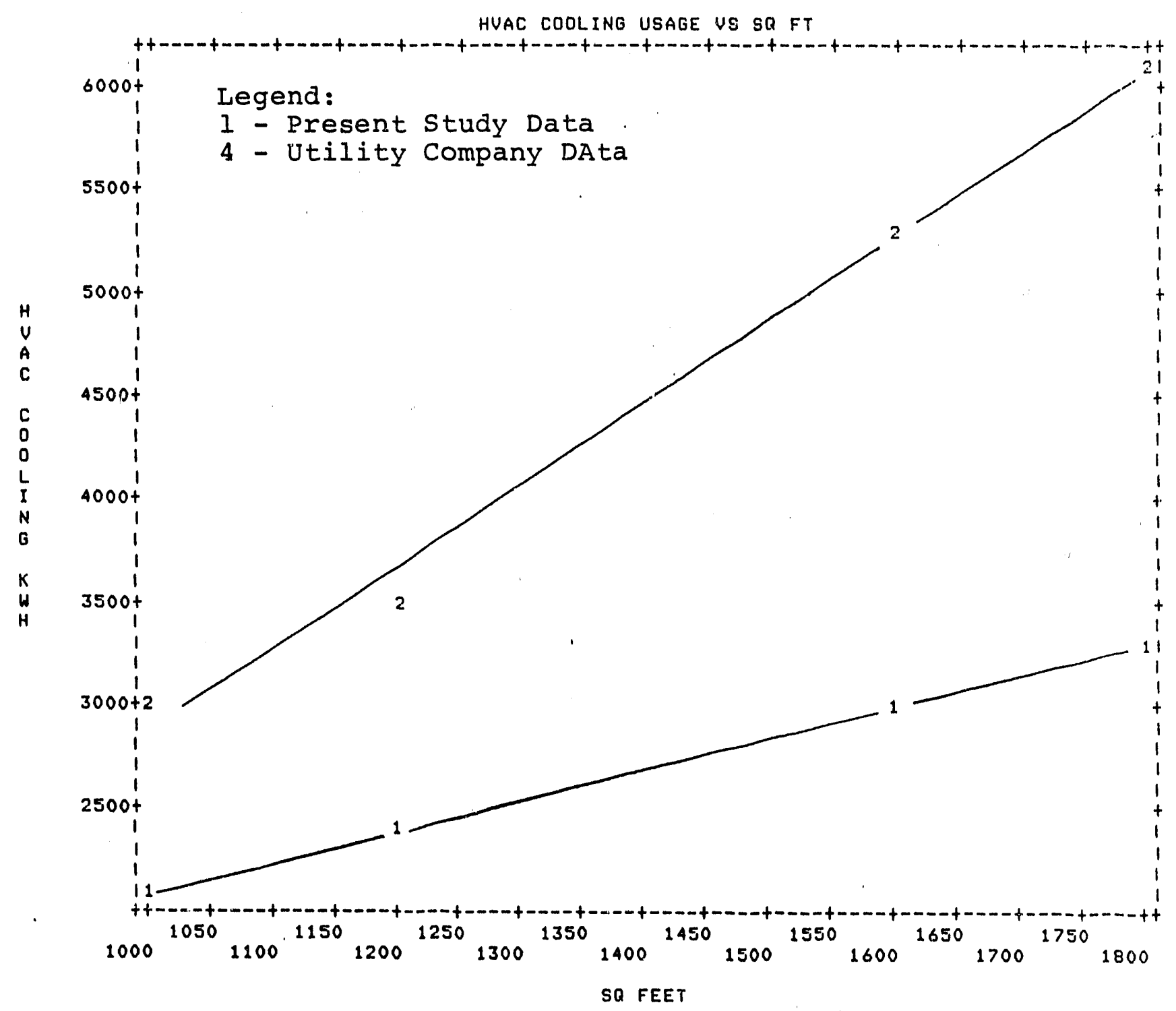

Figure 59 Expanded Scale Comparison of Utility Company and Present Study Cooling Usage Data vs House Size 
TABLE 10

COMPARISON OF COOLING ENERGY USAGE FOR CONVENTIONALLY BUILT AND CONTROLLED CONSTRUCTION HOUSES

$\begin{array}{lccc}\begin{array}{l}\text { House } \\ \text { Size } \\ \text { Sq Ft }\end{array} & \begin{array}{c}\text { Controlled } \\ \text { Construction } \\ \text { House KWH }\end{array} & \begin{array}{c}\text { Conventional } \\ \text { House } \\ \text { RWH }\end{array} & \begin{array}{c}\text { \% Energy } \\ \text { Usage } \\ \text { Reduction }\end{array} \\ 1000 & 2130 & 3000 & 29.0 \\ 1200 & 2420 & 3500 & 30.9 \\ 1600 & 2999 & 5250 & 42.9 \\ 1800 & 3288 & 6100 & 46.1\end{array}$

It appears that substantial energy savings may be achieved year round if a comprehensive energy package is implemented during the construction of the home. 


\section{CHAPTER VI}

\section{SUMMARY OF RESULTS}

The experimental study of residential energy consumption is unique when compared to other collected data. The novelty of the data is that each structure has a common "energy package" whose installation was controlled during the construction process. For each house, the insulation and HVAC systems are known. Therefore, two data sets are now available for further study, i.e.,

1) Cooling season energy usage data for 1985 and 1986 for 130 rouses collected on a daily basis with the exception of weikends.

2) Heating, base, and total energy usage data for 186 houses of varying size collected over a seven-year period, the maximum period for any one house being four years.

These data are tabulated in the appendices but are also available on computer disks from the Department of Mechanical Engineering, Tennessee State University. Analysis of the cooling data revealed that the HVAC energy usage for a specific house correlated best with cooling degree-hours and worst with cooling degree-days while 
average period temperature correlations lay in between. For individual housing units, a cumulative degree-hour approach was taken for the cooling season. For all cases investigated, correlation coefficients were greater than 0.9600 indicating that one may predict cooling usage if the cooling degree-hours are known for a specific period. However, cooling usage characteristics varied greatly among units of identical floor plans which could be attributed to thermostat setting, equipment efficiency, and/or the design cooling load. A comparison of several cooling models indicated that the bin and cooling degree-hour methods give comparable results while the "gross method" significantly overpredicts the cooling usage.

Regression analyses were performed on the following energy usage variables: 1) base usage per day (BD), 2) heating usage per degree day (HVACDD), and 3) total usage per day (TKWD) as a function of house size (SQ) and number of occupants (NOP). The correlation coefficients are summarized on the following page: 
Dependent Variable

$B D$

$B D$

HVACDD

HVACDD

TKWD

TKWD

$B D$
Independent Variable

R

SQ

0.6022

SQ, NOP

0.7465

SQ

0.6440

$S Q, S Q$

0.6554

SQ

0.7003

SQ, NOP

0.7791

TKWD

The statistical analyses indicated a positive relationship between the dependent energy usage variable and SQ. i.e., energy usage (HVAC, base, and total) increases with house size. One interesting result was that the base energy usage was approximately 50 percent of the total energy use.

When the annual space heating and cooling heat pump energy usage of houses in this study were compared with data collected by the local utility company for conventionally built houses in the same geographical area, substantial reduction in energy requirements were noted over the range of house sizes. These results were expected since careful attention to relevant energy conservation details during construction should produce a significant reduction in space conditioning requirements. 


\section{LIST OF REFERENCES}

1. Manual, J. 4th edition, Load Calculation. Air Conditioning Contractors of America, Washington, D.C.

2. Manual, J. 7th edition, Load Calculation. Air Conditioning Contractors of America, Washington, D.C.

3. McQuistion, Faye C. and Jerald D. Parker. Heating, Ventilating, and Air Conditioning, John Wiley and Sons, New Yor k, 1977, p. 432.

4. National Oceanic and Atmospheric Administration, Local Climatological Data, Monthly Summary, Asheville, N.C.

5. SPSSx User's Guide, 2nd edition, McGraw-Hill, New York, 1986 .

6. Schaeffer, Richard L. and James T. MCClave. Statistics for Engineers, Duxbury Press, Boston, ig 82, pp. 239310 .

7. Wise, Renee, Nashville Electric Service, Interview, May, 1987 . 
APPENDIX 1

ENERGY USAGE DATA FOR SUBMETERED HOUSES WITH "ENERGY PACKAGE" 


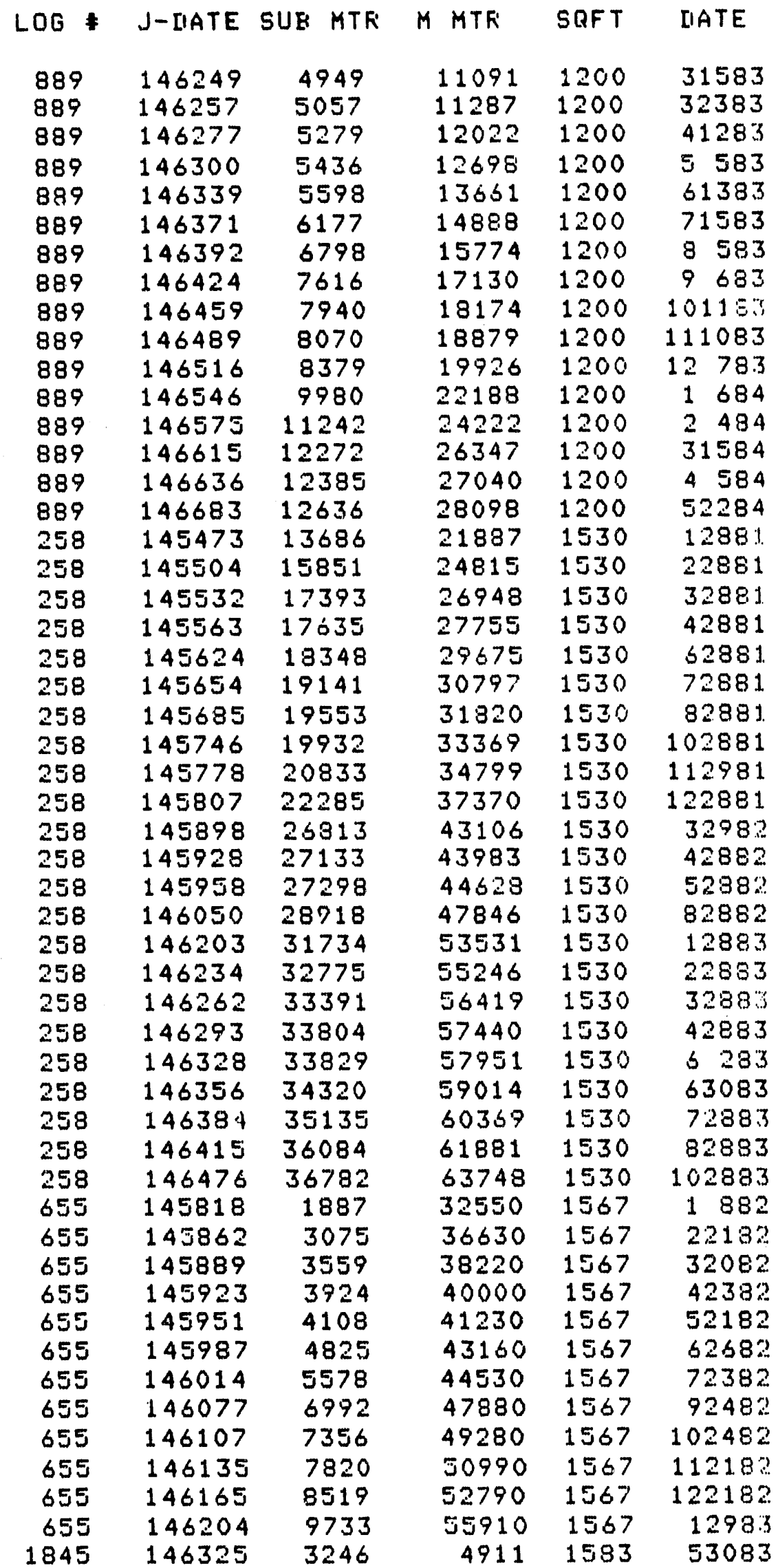




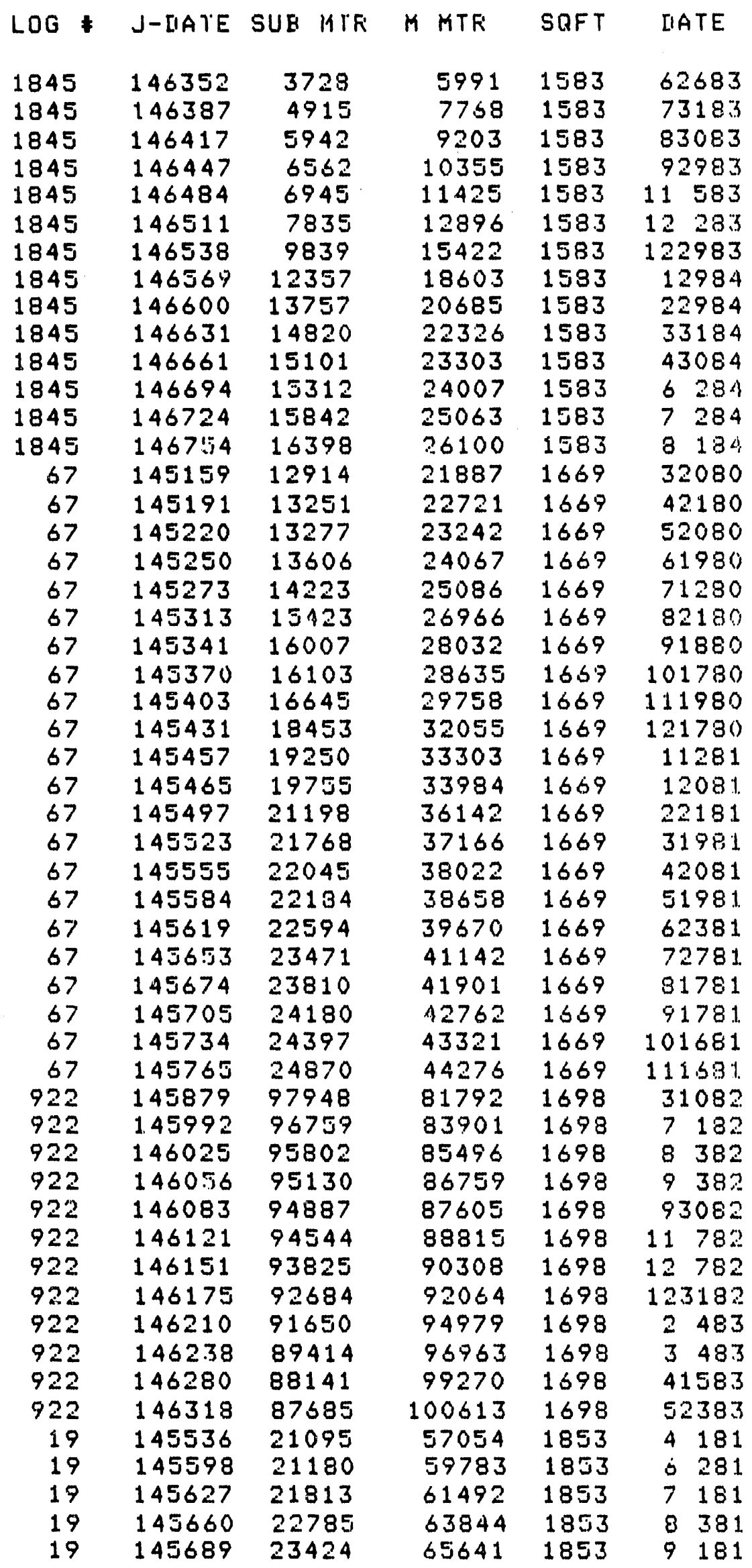




\begin{tabular}{|c|c|c|c|c|c|}
\hline LOG & J-IIATE & SUB MTE & $M M T R$ & SQFT & IIATE \\
\hline 19 & 145719 & 23652 & 67066 & 1853 & 1018 \\
\hline 19 & 145813 & 25247 & 72933 & 1853 & 138 \\
\hline 19 & 145842 & 26697 & 75792 & 1853 & 218 \\
\hline 19 & 145872 & 27848 & 78311 & 1853 & 338 \\
\hline 19 & 145905 & 28323 & 80191 & 1853 & 458 \\
\hline 19 & 145963 & 28836 & 83101 & 1853 & 62 \\
\hline 19 & 145992 & 29183 & 84660 & 18 & 71 \\
\hline 19 & 1460.54 & 956 & 83505 & 1853 & 9 \\
\hline 19 & 146088 & 31167 & 90212 & 1853 & 105 \\
\hline 19 & 14 & 3 & 91566 & 1853 & 111 \\
\hline 19 & 146145 & 31824 & 93252 & 1853 & 121 \\
\hline 19 & 146175 & 32581 & 95432 & 1853 & 12318 \\
\hline 19 & 146206 & 33864 & 98184 & 1853 & 1318 \\
\hline 19 & 1462.35 & 34897 & 100609 & 1853 & 318 \\
\hline 19 & 146267 & 35624 & 102787 & 1853 & 428 \\
\hline 19 & 146326 & 36151 & 105842 & 1833 & 5318 \\
\hline 19 & 146420 & 39186 & 112509 & 1853 & 928 \\
\hline 19 & 146 & 10 & 111 & 1853 & 1038 \\
\hline 19 & $14 E$ & 40463 & 117517 & 1853 & 1228 \\
\hline 438 & 146 & 2445 & 6358 & 1916 & 12268 \\
\hline & 14 & 5211 & 11660 & 191 & 2288 \\
\hline 2438 & 146 & 5914 & 13488 & 1916 & 3278 \\
\hline 2438 & $14 c$ & 6123 & 14745 & 1916 & 4288 \\
\hline 2438 & 14 & 6725 & 17053 & 1916 & 678 \\
\hline 2438 & 146726 & 7507 & 18989 & 1916 & 748 \\
\hline 2438 & 146750 & 8250 & 20672 & 1916 & 7288 \\
\hline 2438 & 146788 & 9758 & 23712 & 1916 & 948 \\
\hline 2438 & 146808 & 10110 & 24873 & 1916 & 924 \\
\hline 2438 & 146 & 10938 & 26923 & 1916 & 1029 \\
\hline 2438 & 146877 & 11463 & 29056 & 1916 & 1228 \\
\hline 2438 & 146903 & 11790 & 30605 & 19 & 12288 \\
\hline 733 & 145 & 1524 & 2790 & 2 & 420 \\
\hline 733 & 145 & 2499 & 51 & 24 & 638 \\
\hline 733 & 14 & 35 & 6 & 2 & 766 \\
\hline 733 & 146 & 4877 & 85 & 24 & 818 \\
\hline 73 & 14 & 6 & 10 & 2 & 946 \\
\hline 73 & 146 & 67 & 12 & 24 & 1028 \\
\hline 733 & 146116 & 7282 & 13 & 24 & 1128 \\
\hline 733 & 146150 & 8282 & 15500 & 2457 & 1268 \\
\hline 733 & 146 & & 176 & 24 & 118 \\
\hline 733 & & & 20 & 24 & 21 \\
\hline 733 & 146 & 12986 & 23 & 24 & 228 \\
\hline 733 & 146 & 1406 & & 24 & 331 \\
\hline 733 & 146 & 148 & 26830 & 2457 & 430 \\
\hline 940 & 146 & 1328 & 67 & 3251 & 120 \\
\hline 940 & 14 & 37 & 124 & 32 & 328 \\
\hline 940 & 14 & 44 & 14640 & 3251 & \\
\hline 940 & 146326 & 471 & 16140 & 3251 & 531 \\
\hline 940 & 146355 & 57 & 17940 & 3251 & \\
\hline 940 & 146387 & & 20270 & 32 & \\
\hline 940 & 146416 & 861 & 22440 & 3251 & \\
\hline 740 & & 10 & 27040 & 3231 & 1129 \\
\hline 940 & 146538 & 13102 & 31420 & 3251 & 12298 \\
\hline
\end{tabular}




\begin{tabular}{|c|c|c|c|c|c|}
\hline LOG * & $J-[I A \backslash E$ & SUB KTR & M MTE & SQFT & IIATE \\
\hline 940 & 146570 & 15548 & 35870 & 3251 & 13084 \\
\hline 940 & 146600 & 16955 & 37370 & 3251 & 22984 \\
\hline 940 & 146630 & 18112 & 39400 & 3251 & 33084 \\
\hline 940 & 146752 & 22810 & 48050 & 3251 & 73084 \\
\hline 910 & 145915 & & 11628 & 2694 & 41582 \\
\hline 910 & 145943 & 8563 & 13192 & 2694 & 51382 \\
\hline 910 & 145975 & 10035 & 15997 & 2694 & 61482 \\
\hline 910 & 146011 & 12158 & 19845 & 2694 & 72082 \\
\hline 910 & 146047 & 14493 & 24072 & 2694 & 82582 \\
\hline 910 & 73 & 15814 & 26526 & 2694 & 92082 \\
\hline 910 & 146097 & 16390 & 28114 & 2694 & 101482 \\
\hline 910 & 146158 & 17604 & 31703 & 2694 & $12148 ?$ \\
\hline 910 & 146196 & 18848 & 34429 & 2694 & 12183 \\
\hline 910 & 146223 & 19764 & 36371 & 2594 & 21783 \\
\hline 910 & 146269 & 20660 & 39053 & 2694 & 4483 \\
\hline 910 & 146461 & 38471 & 56877 & 2694 & 101383 \\
\hline 710 & 145993 & 20008 & 32020 & 3108 & 7282 \\
\hline 710 & 146023 & 22301 & 35660 & 3108 & 8182 \\
\hline 710 & 146054 & 24095 & 38730 & 3108 & 9182 \\
\hline 710 & 85 & 24831 & 40910 & 3108 & $10 \quad 282$ \\
\hline 710 & 146115 & 25552 & 42920 & $310 B$ & 11182 \\
\hline 710 & 146145 & 26846 & 45610 & 3108 & 12182 \\
\hline 710 & 146178 & 29228 & 49840 & 3108 & 1383 \\
\hline 710 & 146207 & 32464 & 54700 & 3108 & 2183 \\
\hline 710 & 146241 & 34912 & 59210 & 3108 & 3783 \\
\hline 710 & 146269 & 36724 & 62450 & 3108 & 4483 \\
\hline 710 & 146297 & 37625 & 64750 & 3108 & 5283 \\
\hline 710 & 146328 & 38086 & 66650 & 3108 & 6283 \\
\hline 710 & 146360 & 39528 & 69510 & 3108 & $74 B 3$ \\
\hline 710 & 146389 & 42535 & 73880 & 3108 & 8283 \\
\hline 710 & 146419 & 43685 & 76220 & 3108 & 9183 \\
\hline 710 & 146449 & 45775 & 79620 & 3108 & 20183 \\
\hline 1187 & 146207 & 4951 & 8081 & 1530 & 2183 \\
\hline 1187 & 146237 & 6098 & 10378 & $15: 30$ & 3383 \\
\hline 1187 & 146269 & 6889 & 12307 & 1530 & 4483 \\
\hline 1187 & 146303 & 7281 & 13885 & 1530 & 5883 \\
\hline 1187 & 146346 & 7704 & 15620 & 1530 & 62083 \\
\hline$: 187$ & 146362 & 8152 & 16492 & 1530 & 7683 \\
\hline 1187 & 146391 & 9079 & 18196 & 1530 & 8483 \\
\hline $1: 87$ & 146423 & 10135 & 19927 & 1530 & 9583 \\
\hline 1187 & 146477 & 10658 & 21665 & 1530 & 102983 \\
\hline 1187 & 146500 & 11224 & 23103 & 1530 & 112183 \\
\hline 1187 & 146548 & 14183 & 27655 & 1530 & 1884 \\
\hline 1188 & 146185 & 1984 & 5448 & 1530 & 11083 \\
\hline 1188 & 146216 & 3110 & 7829 & 1530 & 21083 \\
\hline 1188 & 146244 & 3651 & 9426 & 1530 & 31083 \\
\hline 1188 & 146275 & 4295 & 11114 & 1530 & 41083 \\
\hline 1188 & 146305 & 4519 & 12285 & 1530 & 51083 \\
\hline 1188 & 146397 & 6467 & 17288 & 1530 & 81083 \\
\hline 1188 & 146461 & 7769 & 20886 & 1530 & 101383 \\
\hline 1188 & 146493 & 8031 & 22281 & 1530 & 111483 \\
\hline 1188 & 146584 & 11666 & 29362 & 1530 & 21384 \\
\hline 104 & 146375 & 241 & 1757 & 2457 & 71983 \\
\hline
\end{tabular}




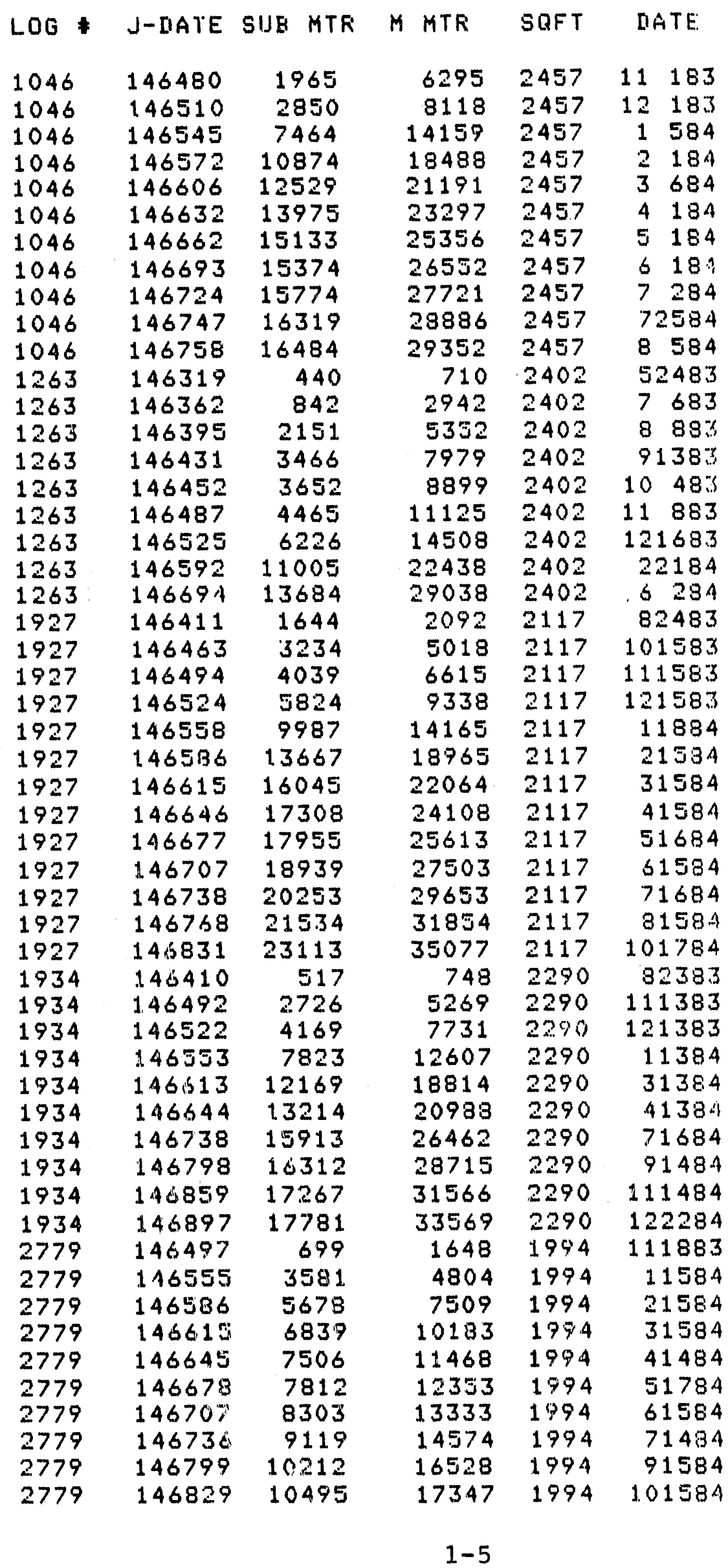




\begin{tabular}{|c|c|c|c|c|c|}
\hline LOG & $J$-[IATE & SUB MTR & M MTE & SQFT & IIATE \\
\hline $\begin{array}{l}2779 \\
2779\end{array}$ & $\begin{array}{l}146862 \\
146890\end{array}$ & $\begin{array}{l}11025 \\
12121\end{array}$ & $\begin{array}{l}18387 \\
20070\end{array}$ & $\begin{array}{l}1994 \\
1994\end{array}$ & $\begin{array}{l}111734 \\
121584\end{array}$ \\
\hline 2458 & 146488 & 2396 & 4701 & 1930 & 11983 \\
\hline 2458 & 146518 & 3589 & 6448 & 1930 & 12983 \\
\hline 2458 & 146549 & 6287 & 10021 & 1930 & 1984 \\
\hline 2458 & 146581 & 9085 & 13396 & 1930 & 21084 \\
\hline 2458 & 146609 & 10111 & 15213 & 1930 & 3984 \\
\hline 2458 & 146640 & 10913 & 16575 & 1930 & 4784 \\
\hline 2458 & 146670 & 11148 & 17570 & 1930 & 5984 \\
\hline 2458 & 146701 & 11406 & 18500 & 1930 & 6984 \\
\hline 2458 & 146731 & 12010 & 19751 & 1930 & 7984 \\
\hline 2458 & 146762 & 12549 & 21162 & 1930 & 8984 \\
\hline 2458 & 146793 & 13217 & 22315 & 1930 & 9984 \\
\hline 2458 & 146823 & 13492 & 23166 & 1930 & 10784 \\
\hline & 146854 & 13666 & 24078 & 1930 & 11984 \\
\hline 2458 & 146884 & 15110 & 26035 & 1930 & 12934 \\
\hline 2458 & 146915 & 16157 & 27750 & 1930 & 1985 \\
\hline 2458 & 146974 & 20181 & 33151 & 1930 & 3985 \\
\hline 2442 & 146431 & 1328 & 2000 & 1919 & 91383 \\
\hline 2442 & 146617 & 3767 & 9302 & 1917 & 31784 \\
\hline 2442 & 146644 & 6038 & 10465 & 1919 & 41384 \\
\hline 2442 & 146703 & 6455 & 11936 & 1919 & 61684 \\
\hline 2442 & 146727 & 6732 & 12577 & 1919 & 7584 \\
\hline 2442 & 146751 & 7091 & 13375 & 1919 & 72984 \\
\hline 2442 & 146783 & 7609 & 14514 & 1919 & 83084 \\
\hline 2442 & 146815 & 7872 & 15449 & 1919 & 10184 \\
\hline 2442 & 146876 & 8524 & 17217 & 1919 & 12184 \\
\hline 2138 & 146357 & 660 & 1819 & 1919 & 7183 \\
\hline 2138 & 146388 & 1673 & 3737 & 1919 & 8183 \\
\hline 2138 & 146419 & 2684 & 5661 & 1919 & 9183 \\
\hline 2138 & 146455 & 3350 & 7414 & 1919 & 10783 \\
\hline 2138 & 146480 & 3554 & 8461 & 1919 & 11183 \\
\hline 2138 & 146510 & 4148 & 10053 & 1919 & 12183 \\
\hline 2138 & 146541 & 5916 & 13025 & 1919 & 1184 \\
\hline 2138 & 146573 & 7848 & 16045 & 1919 & 2284 \\
\hline 2138 & 146600 & 8757 & 17845 & 1719 & 22984 \\
\hline 2138 & 146632 & 10065 & 20303 & 1919 & $4 \quad 184$ \\
\hline 2138 & 146691 & 10446 & 22593 & 1919 & 6284 \\
\hline 2138 & 146723 & 11200 & 24205 & 1919 & $7 \quad 184$ \\
\hline 2138 & 146755 & 12066 & 26008 & 1919 & 8284 \\
\hline 2138 & 146784 & 12800 & 27522 & 1919 & 83184 \\
\hline 2138 & 146811 & 13250 & 28836 & 1719 & 93084 \\
\hline 2138 & 146848 & 13633 & 30234 & 1919 & 11384 \\
\hline 2138 & 146876 & 14323 & 31808 & 1919 & 12184 \\
\hline 2138 & 146907 & 14933 & 33595 & 1919 & 1185 \\
\hline 2248 & 146388 & 1990 & 3981 & 1869 & $\begin{array}{ll}8 & 183\end{array}$ \\
\hline 2248 & 146419 & 2509 & 5067 & 1869 & 9183 \\
\hline 2248 & 146450 & 2835 & 5856 & 1869 & 10283 \\
\hline 2248 & 146481 & & 6435 & 1869 & 11283 \\
\hline 2248 & 146513 & 3427 & 7369 & 1869 & 1248.5 \\
\hline & & 4826 & & & 1284 \\
\hline 2248 & 1.46575 & 5241 & 11109 & 1869 & 2484 \\
\hline 2248 & 146603 & 7075 & 12302 & 1869 & 3384 \\
\hline
\end{tabular}




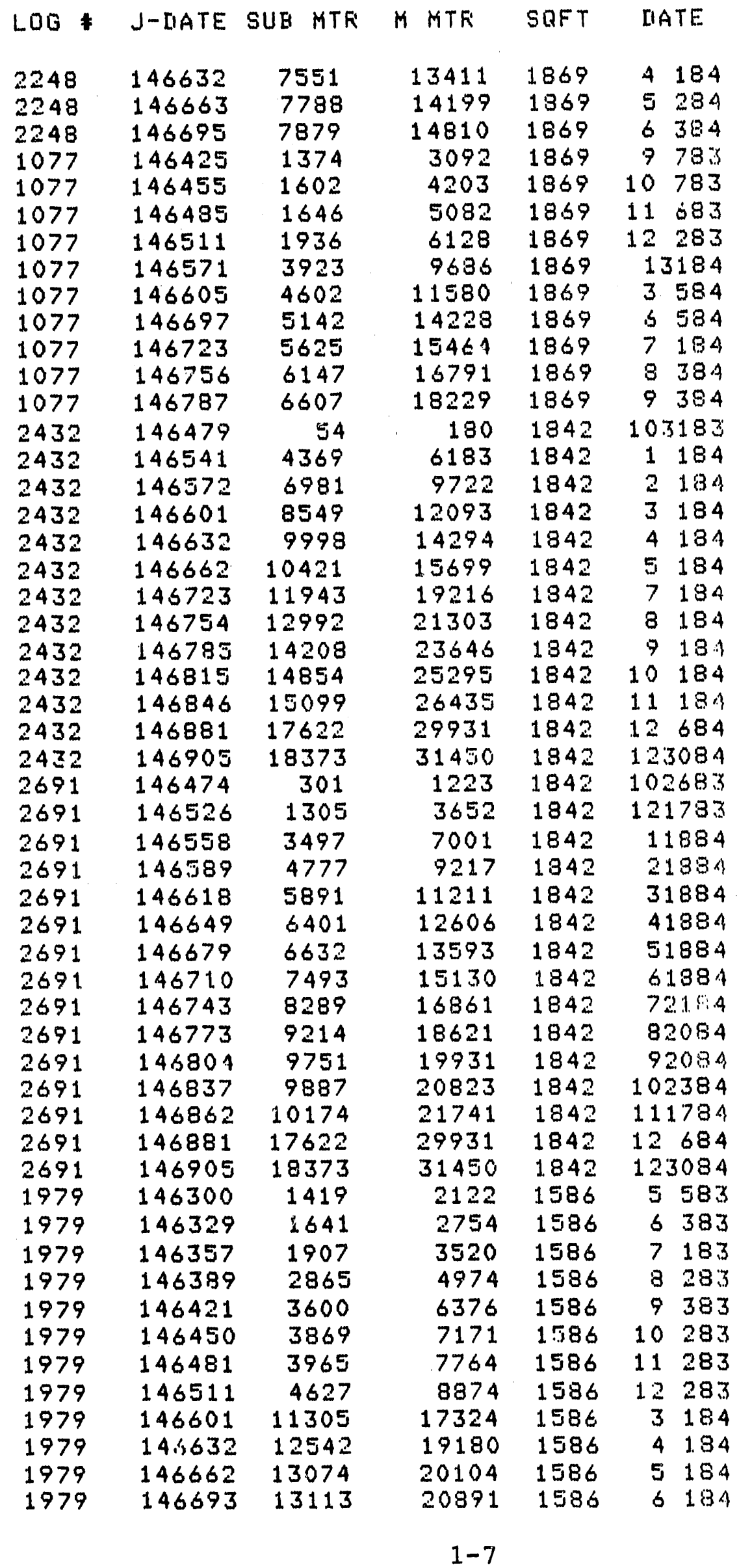




\begin{tabular}{|c|c|c|c|c|c|}
\hline LDG * & J-IIATE & SUE MTK & M MTE & SQFT & IIATE \\
\hline 1979 & 146723 & 13332 & 21563 & 1586 & 718 \\
\hline 1979 & 146755 & 13697 & 22439 & 1586 & 8284 \\
\hline 1979 & 145785 & 14066 & 23406 & 1586 & 9184 \\
\hline 1979 & 146816 & 14244 & 24100 & 1586 & 10284 \\
\hline 1979 & 146846 & 14359 & 24883 & 1586 & 1118.4 \\
\hline 1979 & 146877 & 15605 & 26611 & 1586 & 1228 \\
\hline 1979 & 146970 & 21650 & 34467 & 1586 & 358 \\
\hline 1458 & 146350 & 5407 & 7157 & 1583 & 62483 \\
\hline 1458 & 146390 & 7731 & 10586 & 1583 & 8385 \\
\hline 1458 & 146460 & 10515 & 15252 & 1583 & 101283 \\
\hline 1458 & 146488 & 10796 & 16371 & 1583 & 11983 \\
\hline 1458 & 146539 & 14018 & 21211 & 1383 & 123083 \\
\hline 1458 & 146590 & 17567 & 26601 & 1583 & 2198 \\
\hline 1458 & 146656 & 19168 & 30551 & 1583 & 4258 \\
\hline 1458 & 146682 & 19512 & 31659 & 1583 & 5218 \\
\hline 1458 & 146723 & 20843 & 34211 & 1583 & 718 \\
\hline 1458 & 146715 & 22096 & 36138 & 1583 & 7238 \\
\hline 1458 & 146807 & 24395 & 39255 & 1583 & 92384 \\
\hline 1458 & 146878 & 26062 & 44053 & 1583 & 12384 \\
\hline 2026 & 146305 & 1007 & 19,12 & 1583 & 5108 \\
\hline 2026 & 146 & 1246 & 2793 & 1583 & 628 \\
\hline 2026 & 146 & 2086 & 4521 & 1583 & 728 \\
\hline 2026 & 146 & 3533 & 6958 & 1583 & $\begin{array}{ll}8 & 28 \\
9 & 383\end{array}$ \\
\hline 2026 & 14 & 4872 & 9253 & 15 & 928 \\
\hline 2026 & 14 & 5558 & 11622 & 1583 & 1118 \\
\hline 2026 & 14 & 6221 & 42 & 15 & 1218 \\
\hline 2026 & 146542 & 8284 & 16160 & 1583 & 128 \\
\hline 2026 & 146 & 10326 & 19135 & 1583 & 238 \\
\hline 2026 & 14 & 11476 & 21058 & 1583 & 358 \\
\hline 2026 & 146634 & 12425 & 22615 & 1583 & 438 \\
\hline 2026 & 146 & 12773 & 23638 & 1583 & 538 \\
\hline 2357 & 146 & 1812 & 2851 & 1583 & 8158 \\
\hline 2357 & 146472 & 2551 & 4531 & 1533 & 10248 \\
\hline 2357 & 146503 & 3086 & 5518 & 1583 & 11248 \\
\hline 2357 & 146536 & 4886 & 8088 & 1583 & 12278 \\
\hline 2357 & 146567 & 7228 & 11087 & 1583 & 1278 \\
\hline 2357 & & 8556 & 12818 & & 22 \\
\hline 2357 & 146626 & 9530 & 14251 & 1583 & 3268 \\
\hline 2357 & 14 & 10063 & 15452 & 15 & 526 \\
\hline 2357 & 146718 & 10501 & 16556 & 1583 & 6268 \\
\hline 2357 & 14 & 11191 & 17847 & 1583 & 7258 \\
\hline 2357 & 146777 & 11927 & 19080 & 1583 & 8248 \\
\hline 2357 & 146813 & 12525 & 20257 & 1583 & 9298 \\
\hline 2357 & 146 & 12599 & 20720 & 1583 & 10278 \\
\hline 2357 & 146869 & 13315 & 21873 & 1583 & 11248 \\
\hline 2357 & 146 & 14519 & 23597 & 1583 & 12278 \\
\hline 2357 & 146932 & 16646 & 26214 & 1583 & 1268 \\
\hline 2618 & 146557 & 1071 & 1342 & 2037 & 1178 \\
\hline 2618 & 146618 & .3969 & 6648 & 2037 & 3188 \\
\hline 2618 & 146649 & 4352 & 8185 & 2037 & 4188 \\
\hline & & 4456 & 9235 & 2037 & 5188 \\
\hline 2618 & 146710 & 5399 & 11057 & 2037 & 6188 \\
\hline \multirow[t]{2}{*}{2618} & 146740 & 6260 & 12644 & 2037 & 7188 \\
\hline & & & & & \\
\hline
\end{tabular}




\begin{tabular}{|c|c|c|c|c|c|}
\hline LOG & J-DATE & SUB MTK & M MTR & SQF T & IIATE \\
\hline 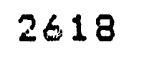 & 146771 & 7640 & 15105 & 2037 & 31884 \\
\hline $\begin{array}{l}2618 \\
2618\end{array}$ & $\begin{array}{l}146802 \\
146832\end{array}$ & $\begin{array}{l}8397 \\
8460\end{array}$ & $\begin{array}{l}16921 \\
18182\end{array}$ & $\begin{array}{l}2037 \\
2037\end{array}$ & $\begin{array}{r}91884 \\
101884\end{array}$ \\
\hline $\begin{array}{l}2618 \\
2618\end{array}$ & $\begin{array}{l}146862 \\
146913\end{array}$ & $\begin{array}{r}9052 \\
11029\end{array}$ & $\begin{array}{l}19511 \\
24517\end{array}$ & $\begin{array}{l}2037 \\
2037\end{array}$ & $\begin{array}{r}111784 \\
1785\end{array}$ \\
\hline $\begin{array}{l}2618 \\
2250\end{array}$ & $\begin{array}{l}146913 \\
116355\end{array}$ & $\begin{array}{r}11029 \\
344\end{array}$ & $\begin{array}{r}24517 \\
686\end{array}$ & $\begin{array}{l}2037 \\
1423\end{array}$ & $\begin{array}{l}1785 \\
62983\end{array}$ \\
\hline 2250 & 146401 & 2280 & 4191 & 1423 & 81483 \\
\hline 2250 & 146432 & 3569 & 6481 & 1423 & 91483 \\
\hline 2250 & 146463 & 3839 & 7809 & 1423 & 101583 \\
\hline 2250 & 146499 & 4369 & 9677 & 1423 & 112083 \\
\hline 2250 & 146547 & 7385 & 14291 & 1423 & 1784 \\
\hline 2250 & 146569 & 9932 & 17921 & 1423 & 12984 \\
\hline 2250 & 146583 & 10791 & 19398 & 1423 & 21284 \\
\hline 2250 & 146655 & 11184 & 22472 & 1423 & 42484 \\
\hline 2250 & 146736 & 13030 & 27352 & 1423 & 71484 \\
\hline 2250 & 14.5765 & 14187 & 29392 & 1423 & 81284 \\
\hline 2449 & 146431 & $\begin{array}{r}889 \\
1728\end{array}$ & $\begin{array}{l}1614 \\
4=0 ?\end{array}$ & 1423 & $\begin{array}{r}91383 \\
172783\end{array}$ \\
\hline 2449 & 14 & 1728 & 4592 & $\begin{array}{l}1423 \\
1423\end{array}$ & $\begin{array}{r}122283 \\
12284\end{array}$ \\
\hline 2449 & 146562 & 3171 & & $14 \leq 3$ & 12284 \\
\hline 2449 & 146.593 & 3827 & 7322 & 1423 & 22284 \\
\hline 2449 & 146653 & 4375 & 9545 & 1423 & 42284 \\
\hline 2449 & 145683 & 4420 & 10230 & 1423 & 52284 \\
\hline 2449 & 146714 & 4670 & 11186 & 1423 & 62284 \\
\hline 2449 & 146744 & 5187 & 12038 & 1423 & 72284 \\
\hline 2449 & 146775 & 5561 & 13182 & 1423 & 82284 \\
\hline 2449 & 146806 & 5815 & 13348 & 1423 & 92284 \\
\hline 2449 & 146836 & 5871 & 14405 & 1423 & 102284 \\
\hline 2449 & 146867 & 6178 & 15284 & 1423 & 112284 \\
\hline 1385 & 146249 & 1835 & 3996 & 1000 & 31583 \\
\hline 1385 & 146280 & 2084 & 4948 & 1000 & 41583 \\
\hline 1385 & 146311 & 2187 & 5873 & 1000 & 51683 \\
\hline 1385 & 146342 & 2248 & 6656 & 1000 & 61683 \\
\hline 1385 & 14 & 2714 & 7803 & 1000 & 71883 \\
\hline 1385 & 146401 & 3346 & 9089 & 1000 & 8178.3 \\
\hline 1385 & 146 & 3998 & 10255 & 1000 & 91883 \\
\hline 1385 & 146465 & 4027 & 11049 & 1000 & 101783 \\
\hline 1385 & 146557 & 6237 & 16811 & 1000 & 11784 \\
\hline 1385 & 146592 & 7635 & 18326 & 1000 & 22184 \\
\hline 1385 & 146617 & 8035 & 19431 & 1000 & 31784 \\
\hline 1385 & 146647 & 8277 & 20356 & 1000 & 41684 \\
\hline 837 & 146083 & 17516 & 58759 & 2602 & 93082 \\
\hline 837 & 146116 & 17906 & 59935 & 2602 & 11282 \\
\hline 837 & 146146 & 19202 & 61978 & 2602 & $12 \quad 282$ \\
\hline 837 & 146175 & 20799 & 64358 & 2602 & $12318 ?$ \\
\hline 837 & 146209 & 24168 & 68568 & 2602 & 2383 \\
\hline 837 & 146237 & 27342 & 72521 & 2602 & 3383 \\
\hline 837 & 146267 & 29242 & 75152 & 2602 & 4283 \\
\hline 837 & 146301 & 30302 & 77031 & 2602 & 5683 \\
\hline 837 & 146333 & 31426 & 78871 & 2602 & 6783 \\
\hline 837 & 146358 & 32034 & 79939 & 2602 & 7283 \\
\hline 837 & 146393 & 32475 & 81191 & 2602 & 8683 \\
\hline 837 & 146424 & 33518 & 82732 & 2602 & 9683 \\
\hline \multirow[t]{2}{*}{1934} & 146410 & 517 & 748 & 2290 & 82.383 \\
\hline & & & $1-$ & & \\
\hline
\end{tabular}




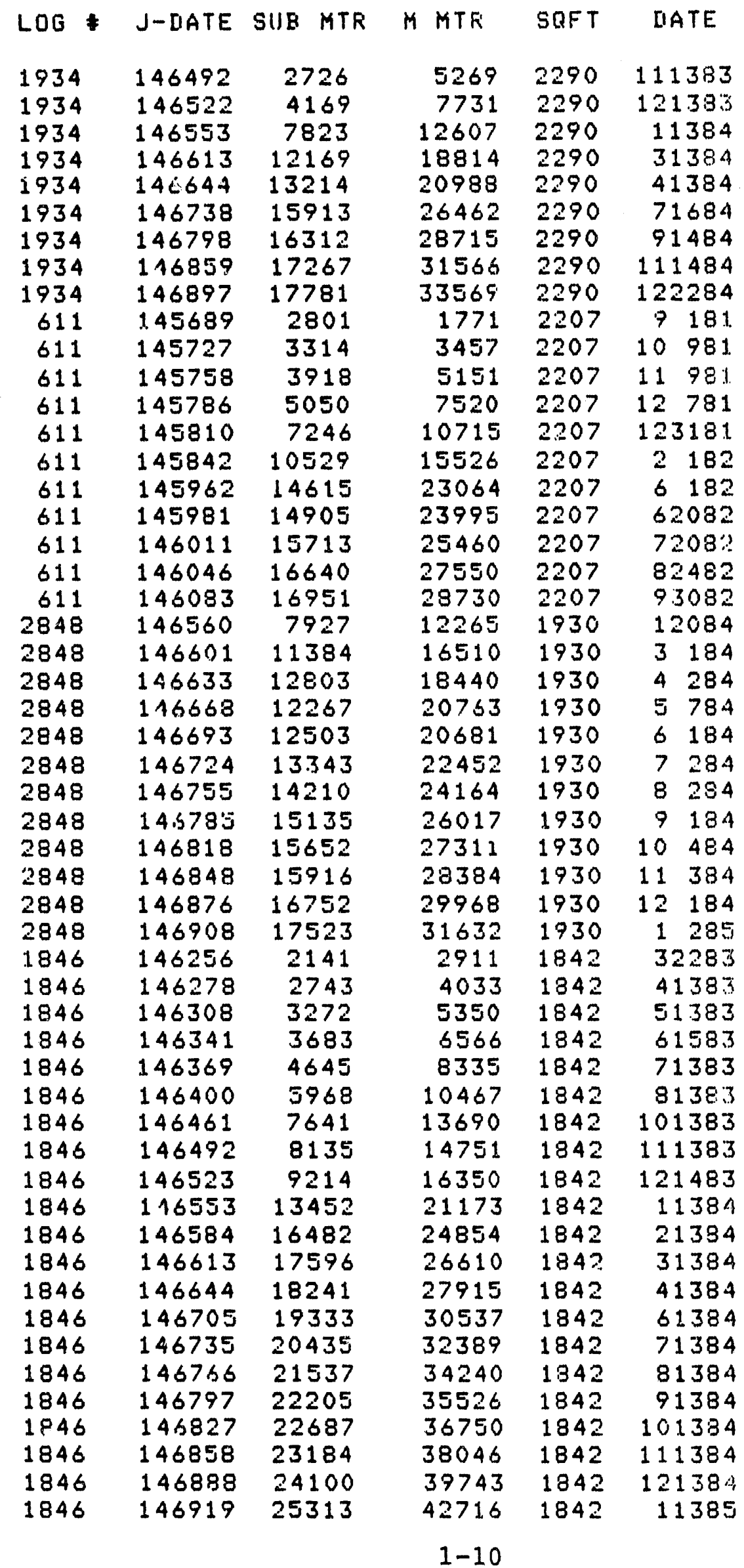




\begin{tabular}{|c|c|c|c|c|c|}
\hline LOG & $J-[I A T E$ & SUE MTR & $M M T E$ & SQFT & IIATE \\
\hline 2457 & 146431 & 2367 & 3705 & 1839 & 91383 \\
\hline 2457 & 146541 & 5302 & 10896 & 1839 & 118.4 \\
\hline 2457 & 146572 & 7343 & 13124 & 1839 & 2184 \\
\hline 2457 & 146601 & 8460 & 15460 & 1839 & 3184 \\
\hline 2457 & 146632 & 9398 & 17626 & 1839 & 4184 \\
\hline 2457 & 146661 & 9550 & 18054 & 1839 & 43084 \\
\hline 2457 & 146693 & 10054 & 20472 & 1839 & 6184 \\
\hline 2457 & 146723 & 11042 & 22641 & 1839 & 7184 \\
\hline 2457 & 146754 & 12255 & 24872 & 1839 & 8184 \\
\hline 2457 & 14.5791 & 13586 & 27434 & 1839 & 9784 \\
\hline 2457 & 146815 & 14196 & 28773 & 1839 & 10184 \\
\hline 2457 & 146846 & 14478 & 30298 & 1839 & 11184 \\
\hline 2457 & 146876 & 15234 & 32202 & 1839 & 12184 \\
\hline 376 & 145354 & 156 & 648 & 1641 & 10180 \\
\hline 376 & 145398 & 1186 & 3314 & 1641 & 111480 \\
\hline 376 & 145412 & 1656 & 4282 & 1641 & 112880 \\
\hline 376 & 145442 & 2784 & 6553 & 1641 & 122880 \\
\hline 376 & 145459 & 3692 & 8167 & 1641 & 11481 \\
\hline 376 & 145500 & 5310 & 11530 & 1641 & 22481 \\
\hline 376 & 145525 & 5886 & 13138 & 1641 & 32181 \\
\hline 376 & 145550 & 6110 & 14310 & 1641 & 41581 \\
\hline 376 & 145580 & 6306 & 15530 & 1641 & $5158 !$ \\
\hline 376 & 145610 & 6641 & 16858 & 1641 & 61481 \\
\hline 376 & 145704 & 8353 & 21525 & 1641 & 91681 \\
\hline 376 & 145734 & 8421 & 22604 & 1641 & 101681 \\
\hline 376 & 145768 & 8663 & 24048 & 1641 & 111981 \\
\hline 376 & 145805 & 9445 & 26234 & 1641 & 122681 \\
\hline 376 & 14582.5 & 10148 & 27745 & 1641 & 11682 \\
\hline 376 & 145855 & 11072 & 29877 & 1641 & 21482 \\
\hline 376 & 145888 & 11494 & 31537 & 1641 & 31982 \\
\hline 376 & 145928 & 11767 & 33210 & 1641 & 42882 \\
\hline 376 & 145950 & 11907 & 34074 & 1641 & 52082 \\
\hline 376 & 145977 & 12292 & 35287 & 1641 & 61682 \\
\hline 376 & 146053 & 13817 & 39000 & 1641 & 33182 \\
\hline 376 & 246068 & 14016 & 39662 & 1641 & 91582 \\
\hline 376 & 146108 & 14288 & 41152 & 1641 & 102582 \\
\hline 376 & 146128 & 14464 & 42162 & 1641 & 111482 \\
\hline 913 & 145915 & 585 & 9763 & 1612 & $4158 ?$ \\
\hline 913 & 145945 & 662 & 10448 & 1612 & 51582 \\
\hline 913 & 145976 & 901 & 11273 & 1612 & 61582 \\
\hline 913 & 146007 & 1445 & 12457 & 1612 & 71682 \\
\hline 913 & 146041 & 2319 & 14431 & 2612 & 81982 \\
\hline 913 & 146068 & 2656 & 15590 & 1612 & $9158 ?$ \\
\hline 913 & 146096 & 2693 & 16239 & 1612 & 101382 \\
\hline 913 & 146128 & 3007 & 17132 & 1612 & 111482 \\
\hline 913 & 146156 & 3568 & 18345 & 1612 & 121282 \\
\hline 913 & 146188 & 4840 & 20679 & 1612 & 11383 \\
\hline 913 & 146220 & 6457 & 23128 & 1612 & 21483 \\
\hline 838 & 145840 & 3811 & 8175 & 1550 & $1308 ?$ \\
\hline \multirow{5}{*}{$\begin{array}{l}838 \\
838 \\
838 \\
838\end{array}$} & 145872 & 5087 & 10801 & 1550 & 3382 \\
\hline & 145901 & 5684 & 12583 & 1550 & 4482 \\
\hline & 145934 & 5967 & 14182 & 1550 & 5482 \\
\hline & 145962 & 6438 & 15492 & 1550 & $6 \quad 18 \%$ \\
\hline & & & $1-11$ & & \\
\hline
\end{tabular}




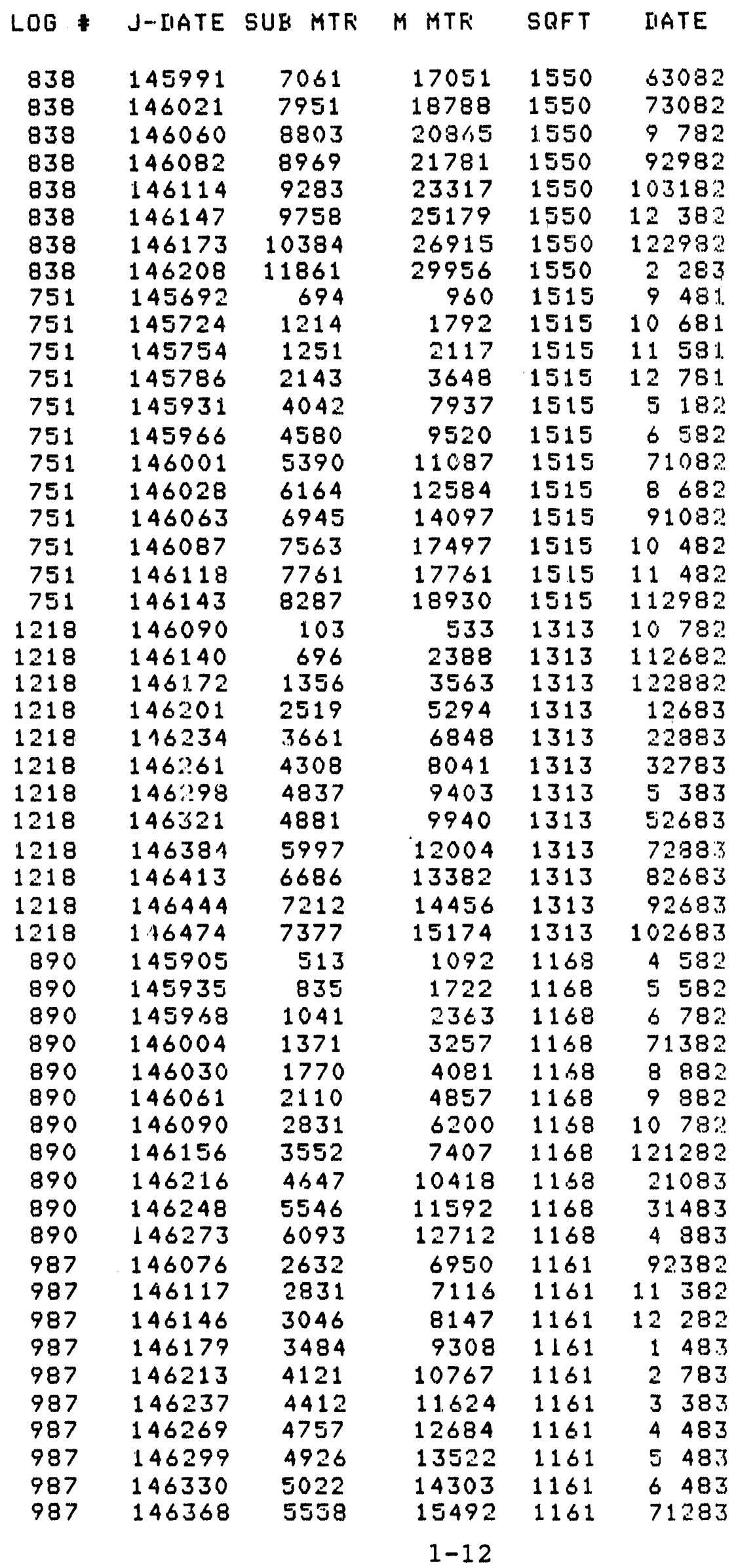




\begin{tabular}{|c|c|c|c|c|c|}
\hline LOG * & $J$ JIATE & SUE MTK & M MTK & SRFT & IIATE \\
\hline $\begin{array}{r}987 \\
1460 \\
1460\end{array}$ & $\begin{array}{l}146423 \\
146305 \\
146418\end{array}$ & $\begin{array}{l}6994 \\
1316 \\
6613\end{array}$ & $\begin{array}{r}17867 \\
2610 \\
10487\end{array}$ & $\begin{array}{l}1161 \\
1583 \\
1583\end{array}$ & $\begin{array}{lr}9 & 583 \\
51083 \\
83183\end{array}$ \\
\hline 1460 & 146451 & 7540 & 12148 & 1583 & 10383 \\
\hline 1460 & 146479 & 7848 & 13162 & 1583 & 103183 \\
\hline 1460 & 146542 & 11367 & 18423 & 1583 & 1284 \\
\hline 1460 & 146571 & 13879 & 21810 & 1583 & 13184 \\
\hline 1460 & 146600 & 15380 & 23936 & 1583 & 22984 \\
\hline 1460 & 146692 & 17581 & 28461 & 1583 & 53184 \\
\hline 1844 & 146256 & 1252 & 1380 & 1583 & 32283 \\
\hline 1844 & 146312 & 1983 & 4536 & 1583 & 5178.3 \\
\hline 1844 & 146342 & 2166 & 5516 & 1583 & 61683 \\
\hline 1844 & 146373 & 2750 & 5585 & 1583 & 71783 \\
\hline 1844 & 146404 & 2845 & 7506 & 1583 & 81783 \\
\hline 1844 & 146436 & 4194 & 9375 & 1583 & 9188.3 \\
\hline 1844 & 146467 & 4991 & 10463 & 1583 & 101983 \\
\hline 1844 & 146498 & 5662 & 11.816 & 1583 & 111923 \\
\hline 1844 & 146529 & 7674 & 15206 & 1583 & 122083 \\
\hline 1844 & 146557 & 9798 & 17663 & 1583 & 11784 \\
\hline 1844 & 146589 & 12069 & 20855 & 1583 & 21884 \\
\hline 1844 & 146618 & 13457 & 23051 & 1583 & 31384 \\
\hline 1844 & 146649 & 14245 & 24713 & 1583 & 41884 \\
\hline 1844 & 146741 & 15775 & 28882 & $\begin{array}{l}1583 \\
1583\end{array}$ & $\begin{array}{l}71.934 \\
81884\end{array}$ \\
\hline 1844 & 146771 & 16598 & 30660 & 1583 & 81884 \\
\hline 1844 & 146802 & 17107 & 31959 & 1583 & 91884 \\
\hline 1844 & 146893 & 19274 & 36653 & 1583 & 121884 \\
\hline 1225 & 116121 & 2131 & 4835 & 1583 & 111082 \\
\hline 1225 & 146156 & 2526 & 6006 & 1583 & 121282 \\
\hline 1225 & 146187 & 3218 & 7570 & 1583 & 11283 \\
\hline 1225 & 146217 & 4216 & 9416 & 1583 & 21183 \\
\hline 1225 & 146247 & 4809 & 10846 & 1583 & 31383 \\
\hline 1225 & 146279 & 5150 & 12112 & 1583 & 41483 \\
\hline 1225 & 146311 & 5308 & 13055 & 1583 & 51683 \\
\hline 1225 & 146342 & 5905 & 14405 & 1583 & 61683 \\
\hline 1225 & 146375 & 7295 & 16473 & 1583 & 71.983 \\
\hline 1225 & 146403 & 8966 & 18805 & 1583 & 81683 \\
\hline 1225 & 146464 & 10773 & 21836 & 1583 & $10168 \%$ \\
\hline 1225 & 146494 & 11028 & 22811 & 1583 & 111583 \\
\hline 1225 & 146551 & 13794 & 27417 & 1583 & 11184 \\
\hline 1225 & 146584 & 15913 & 30405 & 1583 & 21384 \\
\hline 1225 & 146614 & 16621 & $3195 \mathrm{~s}$ & 1583 & 31484 \\
\hline 1225 & 146675 & 17838 & 34500 & 1583 & 51484 \\
\hline 1225 & 116706 & 17912 & 35323 & 1533 & 61484 \\
\hline 1225 & 146766 & 20465 & 38512 & 1583 & 81384 \\
\hline 1225 & 146835 & 21933 & 42348 & 1583 & 102184 \\
\hline 2416 & 146539 & 96934 & 6566 & 2080 & 123083 \\
\hline 2416 & 1466.38 & 91478 & 16598 & 2080 & 4784 \\
\hline 2416 & 146667 & 91004 & 17213 & 2080 & 5684 \\
\hline 2416 & 146698 & 90681 & 18631 & 2080 & $6 \quad 684$ \\
\hline 2416 & 146729 & 90617 & 21652 & 2080 & 7784 \\
\hline 2416 & 146761 & 88509 & 22758 & 2080 & 8884 \\
\hline 2416 & 146791 & 87603 & 25700 & 2080 & 9784 \\
\hline 2416 & 146826 & 87.304 & 25833 & 2080 & 101284 \\
\hline
\end{tabular}




\begin{tabular}{|c|c|c|c|c|c|}
\hline LOG * & $J$ JIAATE & SUE MTF & M MTR & SRFT & IIATE \\
\hline 2416 & 146857 & 86838 & 28231 & 2080 & 111284 \\
\hline $\begin{array}{l}2416 \\
2416\end{array}$ & $\begin{array}{l}146892 \\
146976\end{array}$ & $\begin{array}{l}85467 \\
80882\end{array}$ & $\begin{array}{l}30729 \\
33063\end{array}$ & $\begin{array}{l}2080 \\
2080\end{array}$ & $\begin{array}{r}121784 \\
3118\end{array}$ \\
\hline $\begin{array}{l}2436 \\
2436\end{array}$ & $\begin{array}{l}146510 \\
146548\end{array}$ & $\begin{array}{l}1566 \\
4438\end{array}$ & $\begin{array}{l}4663 \\
9655\end{array}$ & $\begin{array}{l}1930 \\
1930\end{array}$ & $\begin{array}{r}12183 \\
1884\end{array}$ \\
\hline 2436 & 146577 & 6627 & 13304 & 1930 & 2684 \\
\hline 2436 & 146606 & 8872 & 16901 & 1930 & 3684 \\
\hline 2436 & 146666 & 9382 & 19976 & 1930 & 5584 \\
\hline 2436 & 14.6697 & 10915 & 21920 & 1930 & 6581 \\
\hline 2436 & 146760 & 12667 & 27267 & 1930 & 8784 \\
\hline $\begin{array}{l}2436 \\
3436\end{array}$ & $\begin{array}{l}146792 \\
146824\end{array}$ & $\begin{array}{l}13992 \\
14695\end{array}$ & $\begin{array}{l}30802 \\
31852\end{array}$ & $\begin{array}{l}1930 \\
1930\end{array}$ & $\begin{array}{r}9884 \\
101084\end{array}$ \\
\hline $\begin{array}{l}2436 \\
2436\end{array}$ & $\begin{array}{l}146824 \\
146849\end{array}$ & $\begin{array}{l}14695 \\
15295\end{array}$ & $\begin{array}{l}31852 \\
33555\end{array}$ & $\begin{array}{l}1930 \\
1930\end{array}$ & $\begin{array}{l}101084 \\
11484\end{array}$ \\
\hline 2436 & 146886 & 16980 & 36852 & 1930 & 121184 \\
\hline 2446 & 146547 & 9316 & 15060 & 1930 & 1781 \\
\hline 2446 & 146692 & 12085 & 20030 & 1930 & 53184 \\
\hline $\begin{array}{l}2446 \\
2446\end{array}$ & $\begin{array}{l}146725 \\
146788\end{array}$ & $\begin{array}{l}12888 \\
14729\end{array}$ & $\begin{array}{l}22176 \\
25611\end{array}$ & $\begin{array}{l}1930 \\
1930\end{array}$ & $\begin{array}{ll}7 & 384 \\
9 & 484\end{array}$ \\
\hline 2446 & 146912 & 18165 & 32343 & 1930 & 168 \\
\hline 2846 & 146564 & 6296 & 7316 & 1930 & 1248 \\
\hline 2846 & 146609 & 10033 & 12560 & 1930 & 398 \\
\hline 2846 & 146638 & 11285 & 14677 & 1930 & 478 \\
\hline 2846 & 146671 & 11784 & 16078 & 1930 & 5118 \\
\hline 2846 & 146699 & 12570 & 17649 & 1930 & 678 \\
\hline 2846 & 146729 & 13647 & 19555 & 1930 & 778 \\
\hline 2846 & 146757 & 14500 & 21148 & 1930 & 848 \\
\hline 2846 & 146790 & 15588 & 23180 & 1930 & 968 \\
\hline 2846 & 146822 & 15959 & 24590 & 1930 & 10 \\
\hline 2846 & 146851 & 16276 & 25852 & 1930 & 1168 \\
\hline 2846 & 146882 & 17664 & 28322 & 1930 & 1278 \\
\hline 2846 & 146913 & 18640 & 30433 & 1930 & 178 \\
\hline 2440 & 146539 & 2021 & 5339 & 1909 & 123083 \\
\hline 2440 & 146570 & 3166 & 7468 & 1909 & 1308 \\
\hline 2440 & 146600 & 3723 & 9177 & 1909 & 22984 \\
\hline 2440 & 146630 & 4142 & 10436 & 1909 & 33084 \\
\hline 2440 & 146670 & 4285 & $\therefore 1688$ & 1909 & 5984 \\
\hline 2440 & 146692 & 4505 & 12499 & 1909 & 53184 \\
\hline 2440 & 146743 & 5585 & $i 4550$ & 1909 & 72184 \\
\hline 2440 & 146753 & 5716 & 15004 & 1909 & 73184 \\
\hline 2440 & 146784 & 6907 & 17058 & 1909 & 83184 \\
\hline 2440 & 146815 & 7263 & 18305 & 1909 & 10184 \\
\hline 2440 & 146844 & 7608 & 19727 & 1909 & 103084 \\
\hline 2440 & 146882 & 8490 & 21713 & 1909 & 12784 \\
\hline 1307 & 146257 & 6173 & 7241 & 1583 & 32383 \\
\hline 1307 & 146288 & 7542 & 9706 & 1583 & 42383 \\
\hline 1307 & 146318 & 8107 & 11290 & 1583 & 52383 \\
\hline 1307 & 146378 & 10334 & 15225 & 1583 & 72283 \\
\hline 1307 & 146410 & 12306 & 18125 & 1583 & 82383 \\
\hline 1307 & 146441 & 13687 & 20414 & 1583 & 92383 \\
\hline 1307 & 146472 & 14153 & 21689 & 1583 & 102483 \\
\hline 1307 & 146502 & 15260 & 23669 & 1583 & 112383 \\
\hline 1307 & 146534 & 18014 & 27608 & 1583 & 122583 \\
\hline 1307 & 146563 & 22017 & 32666 & 1583 & 1238 \\
\hline
\end{tabular}




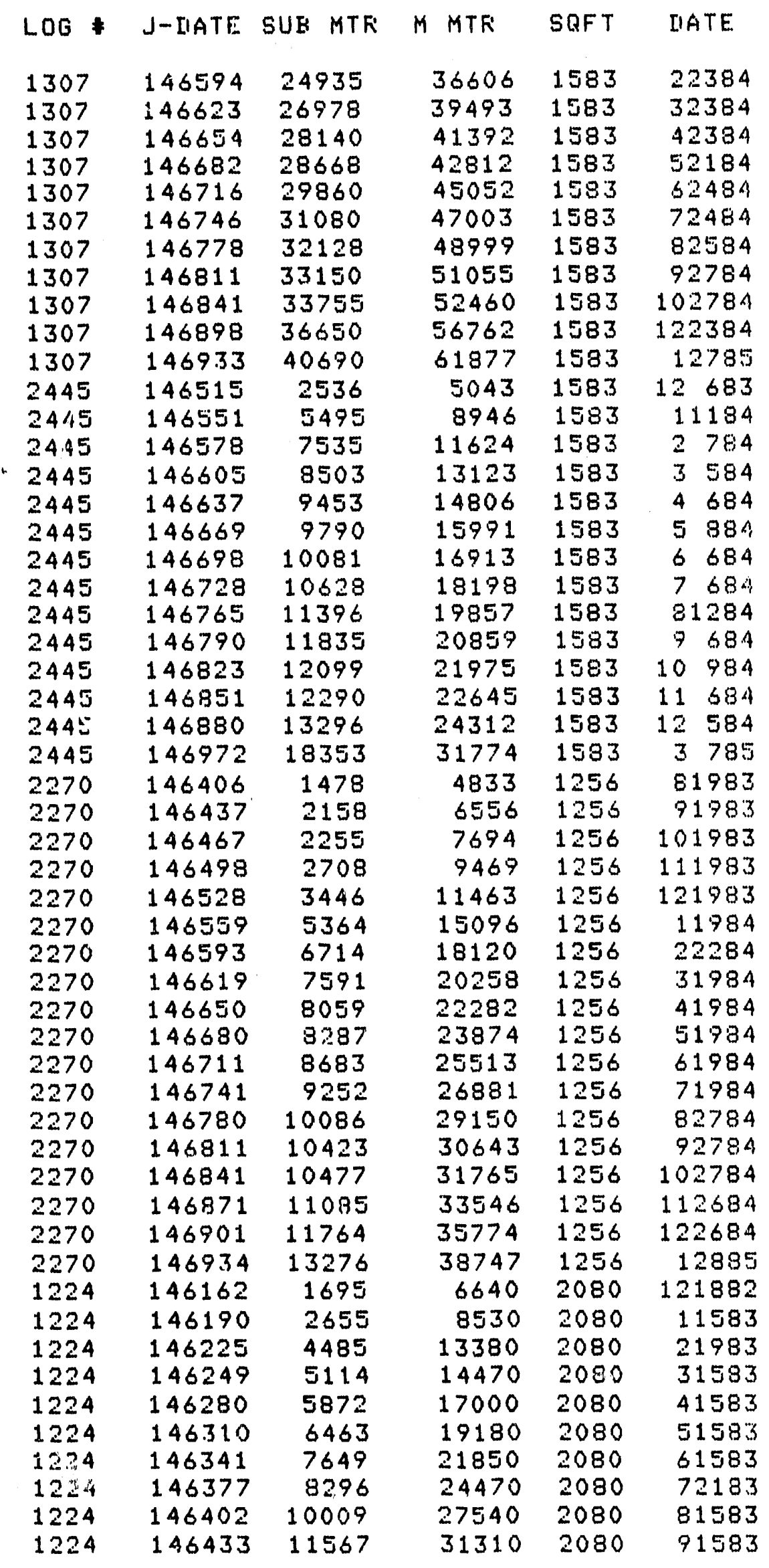




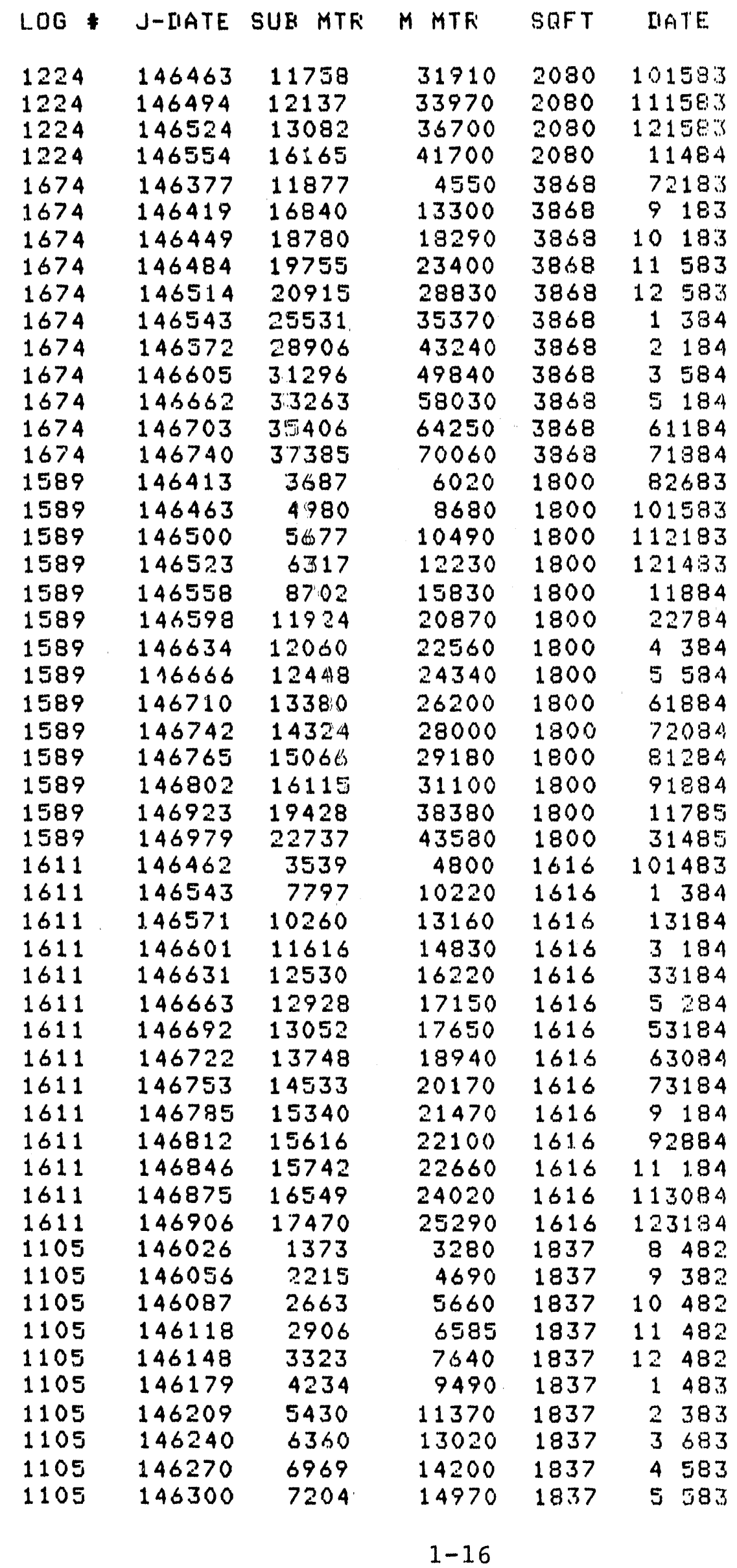




\begin{tabular}{|c|c|c|c|c|c|c|}
\hline$D G *$ & $J$ JIATE & SUE MTF & M MTK & SRFT & \multicolumn{2}{|c|}{ IIATE } \\
\hline 1105 & 146334 & 7406 & 15740 & 1837 & 6 & \\
\hline & 146360 & 8096 & 16880 & 1837 & 7 & \\
\hline & 146391 & 9122 & 18370 & 1837 & 3 & \\
\hline & 146421 & 10229 & 19900 & 1837 & 9 & \\
\hline & 146452 & 10800 & 20950 & 1837 & 10 & \\
\hline 1105 & 146483 & 10973 & 21260 & 1837 & 11 & \\
\hline & 146573 & 14910 & 27740 & 1337 & 2 & - \\
\hline & 146604 & 15021 & 28410 & 1837 & 3 & - \\
\hline & 146635 & 16500 & 30740 & 1837 & 4 & 48 \\
\hline 1105 & 146665 & 16862 & 31470 & 1837 & 5 & 48 \\
\hline 105 & 146696 & 17226 & 32340 & 1837 & 6 & \\
\hline 5 & 146726 & 17903 & 33430 & 1837 & 7 & 48 \\
\hline & 146756 & 18767 & 34760 & 1837 & 3 & 38 \\
\hline 1391 & 146544 & 10325 & 16140 & 1490 & 1 & 10 \\
\hline 1391 & 146570 & 12629 & 18980 & & 13 & \\
\hline 1391 & 146606 & 14410 & 21910 & 1490 & 3 & 68 \\
\hline 1391 & 146639 & 15415 & 23860 & 1490 & 4 & -7 \\
\hline 1391 & 146669 & 15777 & 25140 & 1490 & 5 & 88 \\
\hline 1391 & 146700 & 16076 & 26230 & 1490 & 6 & 88 \\
\hline 1391 & 146728 & 16767 & 27760 & 1490 & 7 & -2 \\
\hline 1391 & 146761 & 17640 & 29720 & 1490 & 8 & 88 \\
\hline 1391 & 146791 & 18309 & 31340 & 1490 & 9 & 78 \\
\hline 1391 & 146822 & 18693 & 32760 & 1490 & 10 & 88 \\
\hline 1391 & 146854 & 19086 & 34250 & 1490 & 11 & 98 \\
\hline 1391 & 146883 & 20310 & 36420 & 1490 & 12 & 86 \\
\hline 1391 & 146914 & 21339 & 38400 & 1490 & 1 & $8 \varepsilon$ \\
\hline 1391 & 146973 & 25461 & 44580 & 14 & 3 & 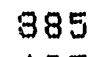 \\
\hline 1602 & 146332 & 4 & 9850 & 1490 & 6 & 68 \\
\hline 1602 & 146361 & 356 & 10580 & 1490 & 7 & \\
\hline & 146 & 1186 & 11950 & 1490 & 8 & \\
\hline 1602 & 146424 & 1984 & 13190 & 1490 & 9 & \\
\hline 1602 & 146 & 2258 & 13780 & 1490 & 10 & \\
\hline 1602 & 14 & 2533 & 14590 & 1490 & 11 & \\
\hline 1602 & 146 & 3377 & 15960 & 1490 & 12 & \\
\hline 1602 & 146 & 5175 & 13320 & 1490 & 1 & \\
\hline 1602 & 146577 & 7424 & 21150 & 1490 & 2 & \\
\hline 1602 & 146 & 8382 & 22540 & 1490 & 3 & \\
\hline 1602 & 146639 & 9177 & 24050 & 1490 & 4 & \\
\hline 1602 & 146664 & 9382 & 24770 & 1490 & 5 & \\
\hline 1602 & 146697 & 9594 & 25590 & 1490 & 6 & \\
\hline 1405 & 143328 & 920 & 59060 & 1490 & 6 & \\
\hline 1405 & 146360 & 1835 & 60620 & 1490 & 7 & \\
\hline 1405 & 146.391 & 2065 & 62480 & 1490 & 8 & \\
\hline 1405 & 146432 & 3317 & 64770 & 1490 & 91 & \\
\hline 14 & 146454 & 3420 & 65340 & 1490 & 10 & \\
\hline 14 & 146485 & 3463 & 66090 & 1490 & 11 & \\
\hline & $14 t$ & 5186 & 70060 & 1490 & 1 & \\
\hline 1405 & 146577 & 6536 & 72760 & 1490 & 2 & \\
\hline 1405 & 146697 & 7840 & 79180 & 1490 & 6 & \\
\hline 14 & 146789 & 10451 & 83480 & 1490 & 9 & \\
\hline 1392 & 146493 & 306 & 7080 & 1490 & 1 & \\
\hline 13 & 146 & 985 & 8140 & 1490 & & \\
\hline 1392 & 146550 & 2857 & 10930 & 1490 & 1 . & \\
\hline
\end{tabular}




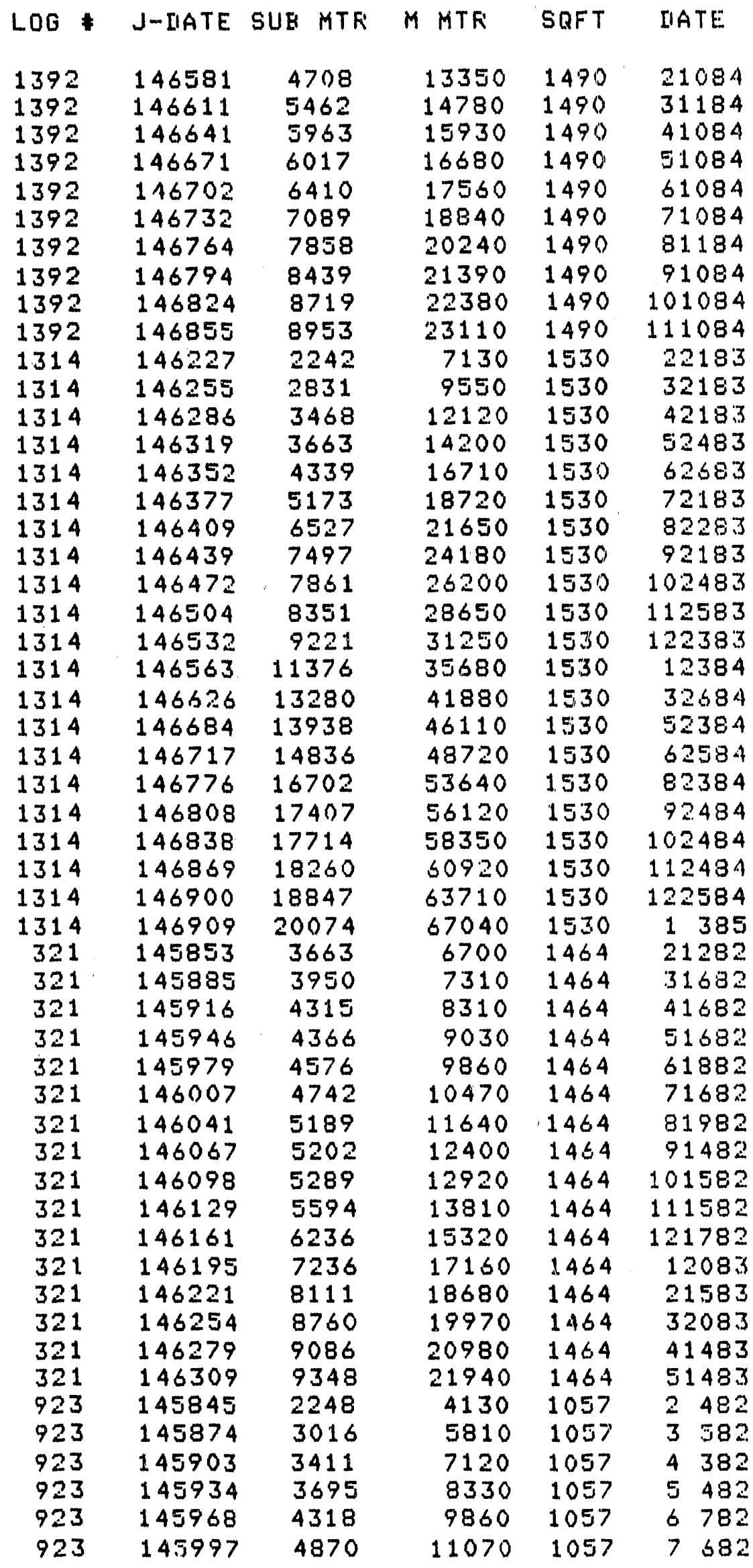




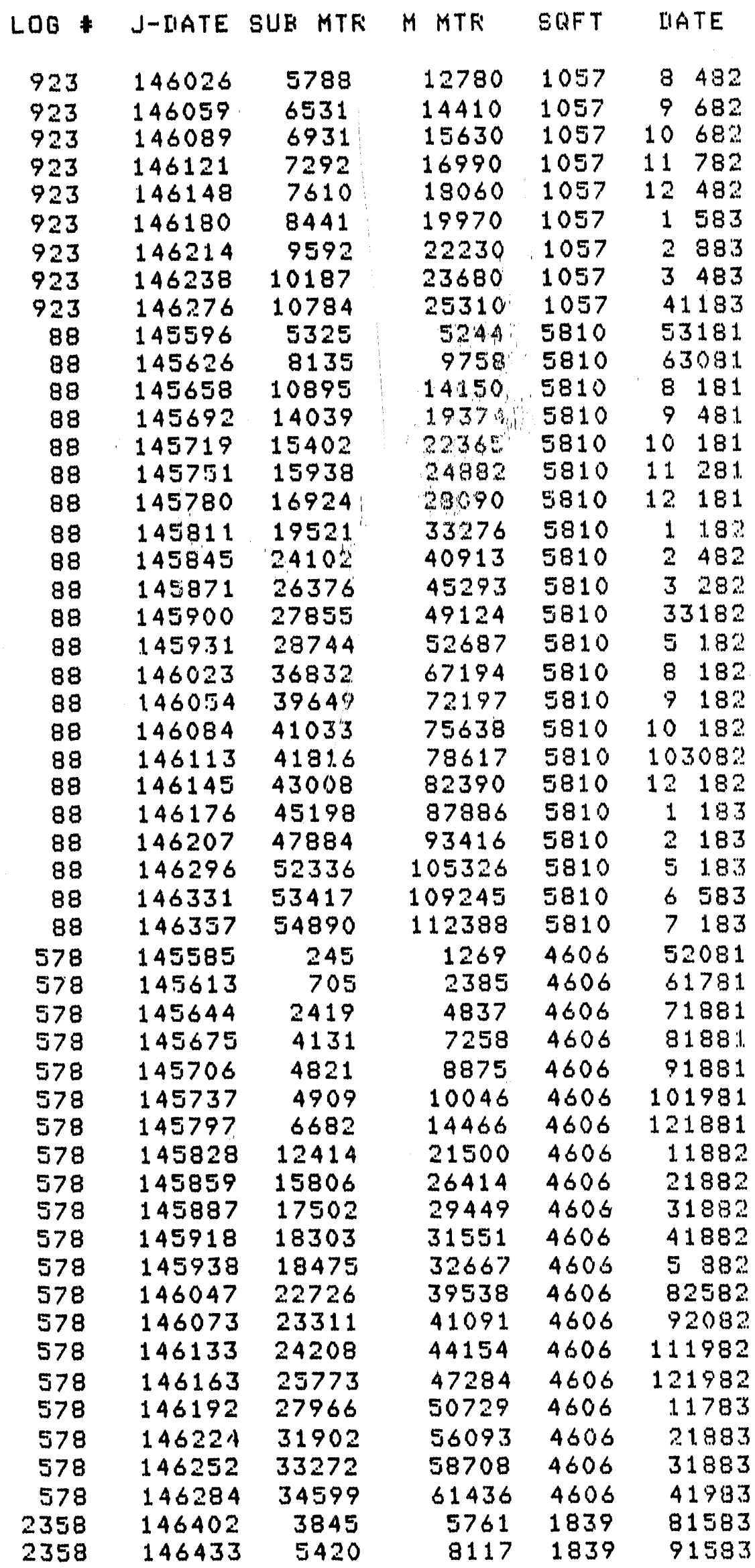




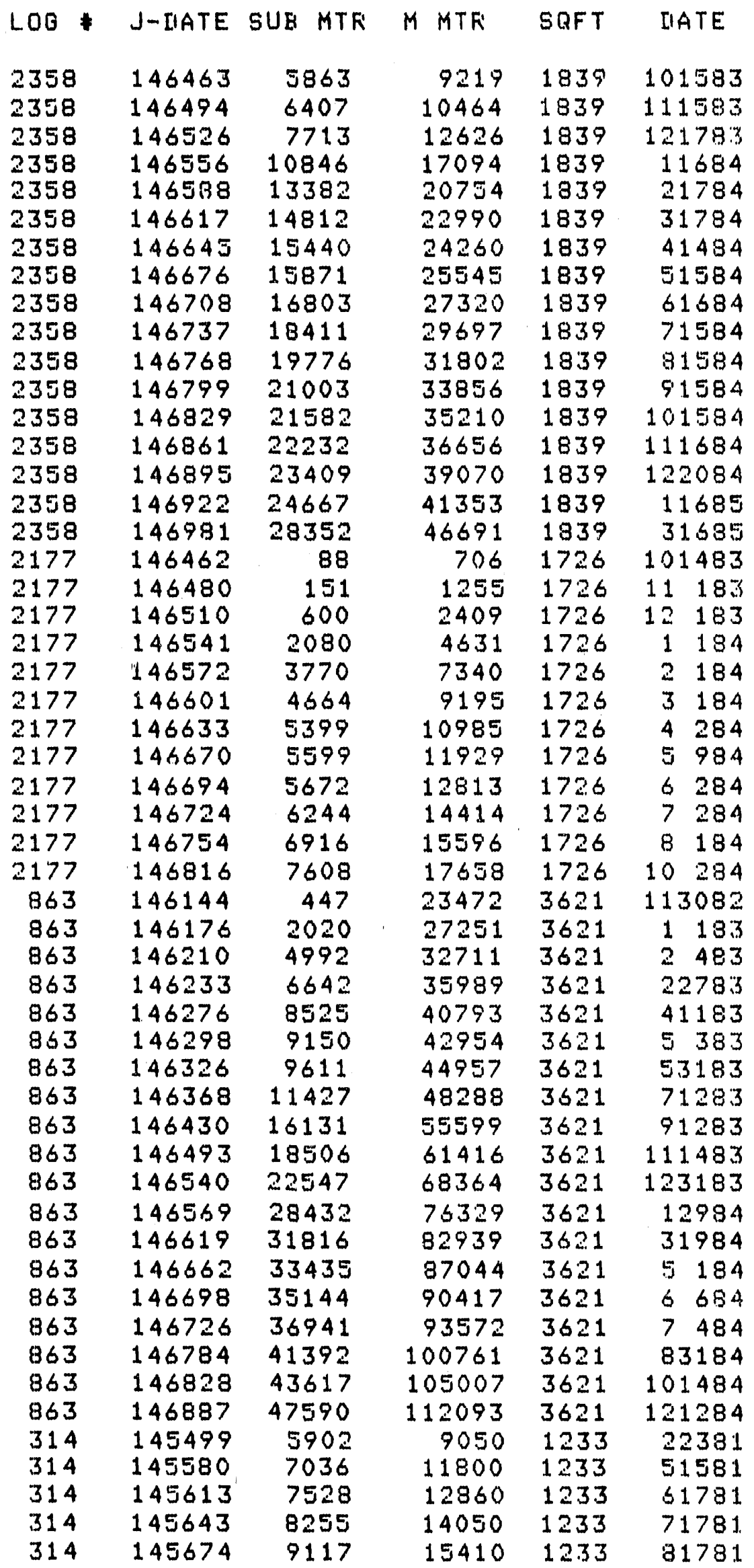




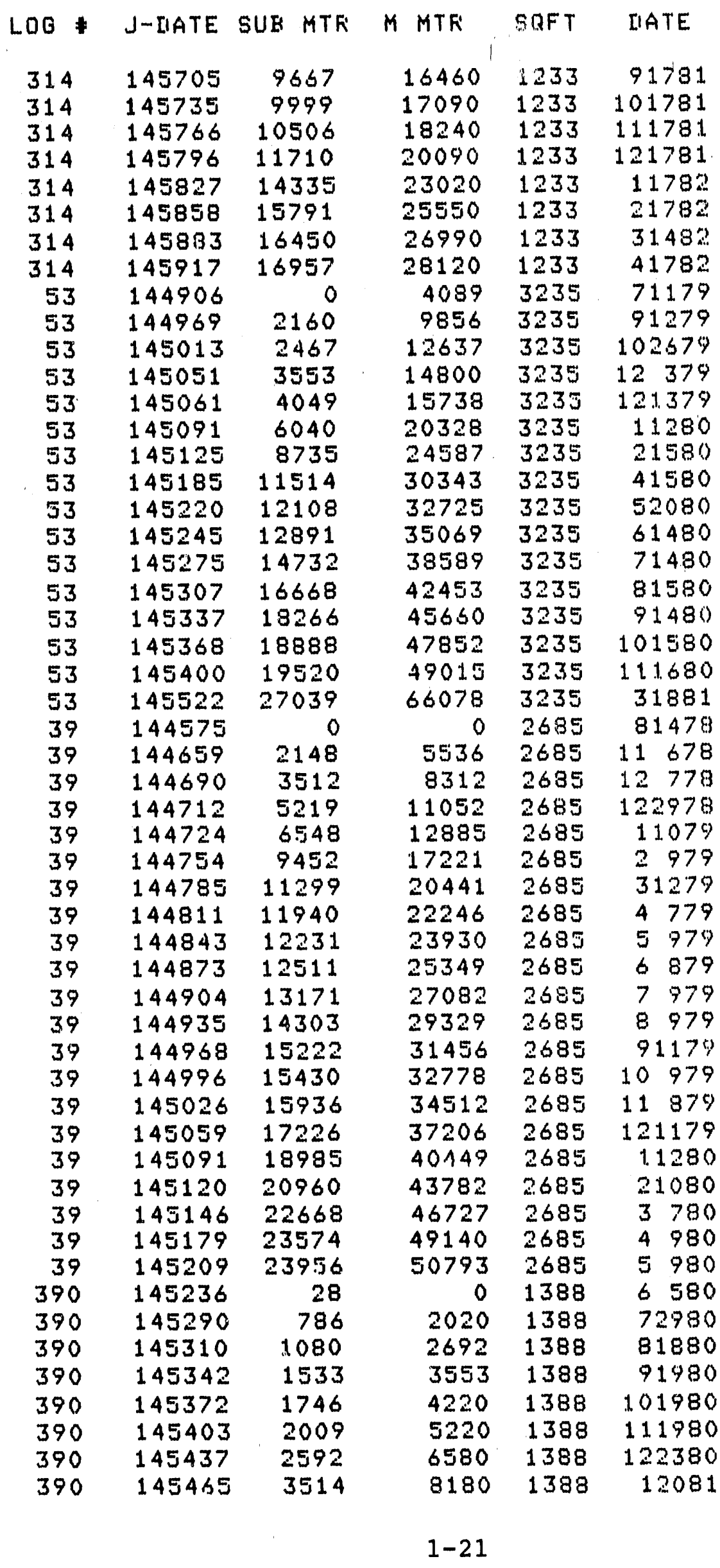




\begin{tabular}{|c|c|c|c|c|c|}
\hline$-0 G$ & $J$ JIIATE & SUE MTK & M MTK & SQFT & IIATE \\
\hline 39 & $\begin{array}{l}145500 \\
145523\end{array}$ & $\begin{array}{l}4445 \\
4838\end{array}$ & $\begin{array}{l}10000 \\
10940\end{array}$ & $\begin{array}{l}1388 \\
1388\end{array}$ & $\begin{array}{l}224 \\
319\end{array}$ \\
\hline $\begin{array}{l}390 \\
390 \\
390\end{array}$ & $\begin{array}{l}145556 \\
145617 \\
145646\end{array}$ & $\begin{array}{l}5077 \\
5559 \\
5051\end{array}$ & $\begin{array}{l}11990 \\
12880 \\
14580\end{array}$ & $\begin{array}{l}1388 \\
1388 \\
1338\end{array}$ & $\begin{array}{l}4218 \\
6218 \\
7208\end{array}$ \\
\hline 158 & 145221 & 8367 & 13020 & 2141 & 5216 \\
\hline 158 & 145234 & 8395 & 14180 & 2141 & \\
\hline 158 & 145264 & 9350 & 16130 & 2141 & $73 \varepsilon$ \\
\hline 158 & 145300 & 11252 & 19120 & 2141 & 88 \\
\hline 158 & 145328 & 12539 & 21350 & 2141 & 958 \\
\hline 158 & 145387 & 13815 & 24840 & 2141 & 1138 \\
\hline 158 & 145419 & 15143 & 27480 & 2141 & 1258 \\
\hline 158 & 145450 & 17189 & 31000 & 2141 & 158 \\
\hline 158 & 145478 & 19917 & 35120 & 2141 & 228 \\
\hline 158 & 145509 & 22155 & 38820 & 2141 & 358 \\
\hline 158 & 145538 & 23323 & 41310 & 2141 & 438 \\
\hline 158 & 145689 & 26883 & 50250 & 2141 & 918 \\
\hline 158 & 145699 & 27064 & 50780 & 2141 & 9118 \\
\hline 158 & 145782 & 29342 & 55632 & 2141 & 1238 \\
\hline 158 & 145813 & 32445 & 61010 & 2141 & 138 \\
\hline 158 & 145858 & 37082 & 67800 & 2141 & 2.178 \\
\hline 158 & 145872 & 37804 & 69200 & 2141 & 338 \\
\hline 158 & 145933 & 39555 & 73580 & 2141 & 538 \\
\hline 158 & 146026 & 42815 & 80200 & 2141 & 848 \\
\hline 158 & 146085 & 44276 & 84140 & 2141 & 1028 \\
\hline 158 & 146179 & 48475 & 92110 & 2141 & 148 \\
\hline 158 & 146209 & 51588 & 96460 & 2141 & 238 \\
\hline 158 & & 53727 & 100 & 2141 & 348 \\
\hline 66 & 144 & 5393 & 9 & 23 & 217 \\
\hline 66 & & 10793 & & 2342 & 89 \\
\hline 66 & 145005 & 11883 & 23028 & 2342 & 10187 \\
\hline 66 & 145035 & 12441 & 2.5054 & 2342 & 11177 \\
\hline 66 & 145066 & 13641 & 27766 & 2342 & 12187 \\
\hline 66 & 145097 & 14725 & 30500 & 2342 & 1 \\
\hline 66 & 145130 & 16347 & 33955 & 2342 & 220 \\
\hline 66 & 145159 & 17397 & 36494 & 2342 & 3208 \\
\hline 66 & 145192 & 17915 & 38641 & 2342 & 4228 \\
\hline 66 & 145220 & 18046 & 39971 & 2342 & 520 \\
\hline 66 & 145251 & 18622 & 41825 & 2342 & 620 \\
\hline 66 & 145286 & 20106 & 44841 & 2342 & 7258 \\
\hline 458 & 145450 & 3510 & 5670 & 2326 & 158 \\
\hline 458 & 14 & 7137 & 11745 & 2326 & 221 \\
\hline 458 & & 7977 & 13835 & 2326 & \\
\hline 458 & 14 & 8063 & 15316 & 2326 & 42 \\
\hline 458 & 1. & 8635 & $\begin{array}{l}16675 \\
18136\end{array}$ & $\begin{array}{l}2326 \\
2326\end{array}$ & \\
\hline & & 9172 & & & \\
\hline 458 & 145681 & $1055 ?$ & 22465 & 2326 & 82 \\
\hline 458 & 145716 & 10985 & 24 & 2326 & 928 \\
\hline 458 & 145742 & 11075 & & 2326 & 10248 \\
\hline 458 & 145771 & 11548 & 27204 & 2326 & 11228 \\
\hline 458 & 14 & 15342 & 33 & 2326 & \\
\hline 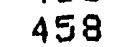 & 115862 & 16936 & 36949 & 2326 & 22 \\
\hline
\end{tabular}




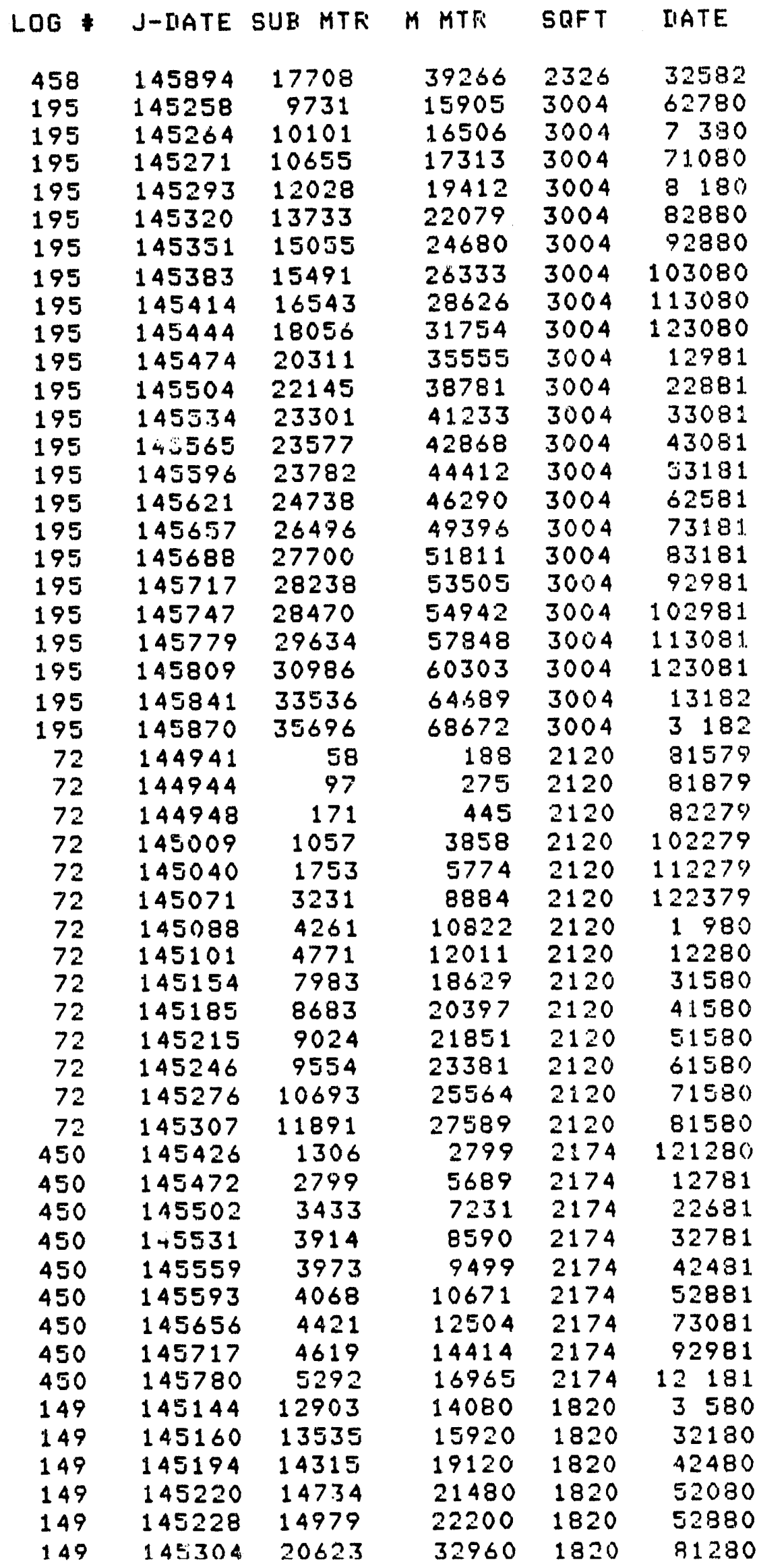

$1-23$ 


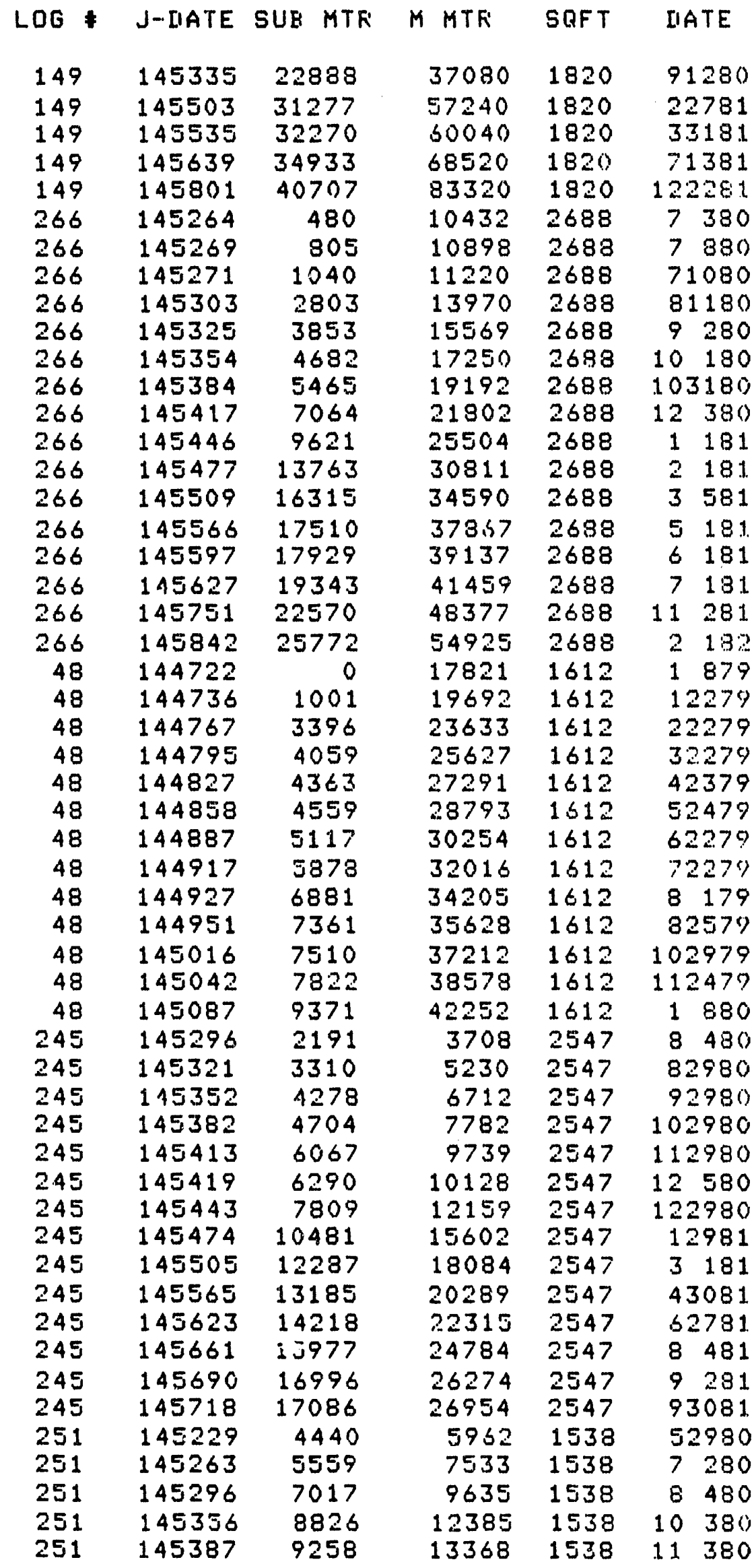




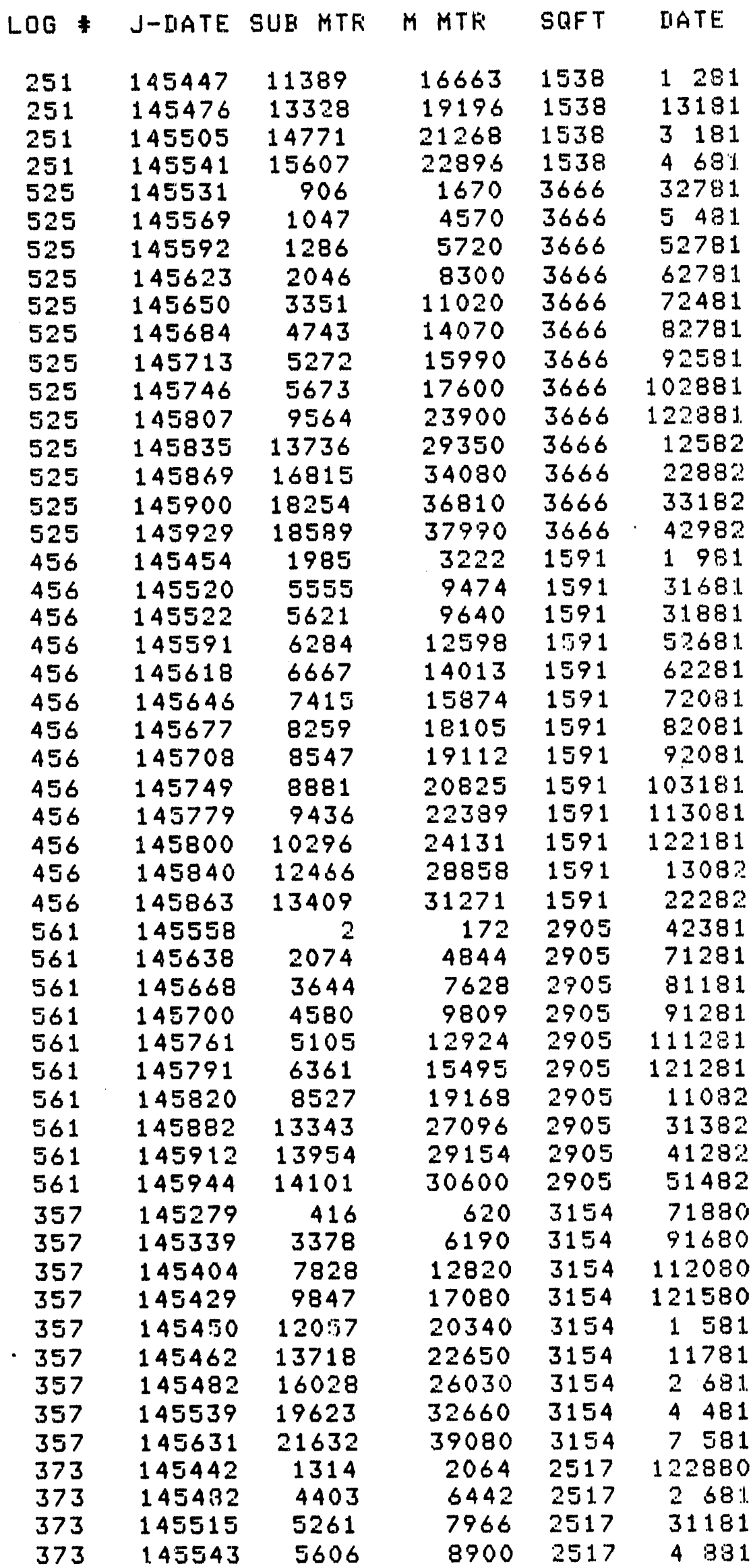




\begin{tabular}{|c|c|c|c|c|c|}
\hline LOG * & J-IIATE & SUE MTK & M MTF & SQFT & IIATE \\
\hline $\begin{array}{l}373 \\
373 \\
373 \\
373\end{array}$ & $\begin{array}{l}145573 \\
145605 \\
115627 \\
145637\end{array}$ & $\begin{array}{l}5606 \\
5661 \\
6194 \\
6470\end{array}$ & $\begin{array}{r}9476 \\
10102 \\
11077 \\
11499\end{array}$ & $\begin{array}{l}2517 \\
2517 \\
2517 \\
2517\end{array}$ & $\begin{array}{ll}5 & 881 \\
6 & 981 \\
7 & 181 \\
7 & 1181\end{array}$ \\
\hline $\begin{array}{l}373 \\
373\end{array}$ & $\begin{array}{l}145665 \\
145697\end{array}$ & $\begin{array}{l}7432 \\
8009\end{array}$ & $\begin{array}{l}12962 \\
14131\end{array}$ & $\begin{array}{l}2517 \\
2517\end{array}$ & $\begin{array}{ll}8 & 38 \\
9 & 98\end{array}$ \\
\hline $\begin{array}{l}373 \\
373\end{array}$ & $\begin{array}{l}145724 \\
145758\end{array}$ & $\begin{array}{l}8098 \\
8144\end{array}$ & $\begin{array}{l}14780 \\
15438\end{array}$ & $\begin{array}{l}2517 \\
2517\end{array}$ & $\begin{array}{ll}10 & 68 \\
11 & 98\end{array}$ \\
\hline 373 & 145791 & 8711 & 16771 & 2517 & 12128 \\
\hline 373 & 145817 & 9732 & 18379 & 2517 & 178 \\
\hline 373 & 145847 & 16028 & 26030 & 2517 & 268 \\
\hline 373 & 145904 & 19623 & 32660 & 2517 & 448 \\
\hline 373 & 145996 & 21632 & $390: 30$ & 2517 & 758 \\
\hline 94 & 145223 & 2 & 7986 & 3290 & 5238 \\
\hline 94 & 145251 & 785 & 10248 & 3290 & 6208 \\
\hline 94 & 145269 & 1853 & 11721 & 3290 & 788 \\
\hline 94 & 145281 & 3104 & 13464 & 3290 & 7208 \\
\hline 94 & 145291 & 3661 & 14462 & 3290 & 730 \\
\hline 94 & 145312 & 5242 & 16846 & 3290 & 826 \\
\hline $\begin{array}{l}94 \\
94\end{array}$ & $\begin{array}{l}145343 \\
145373\end{array}$ & $\begin{array}{l}6547 \\
6836\end{array}$ & $\begin{array}{l}19414 \\
20902\end{array}$ & $\begin{array}{l}3290 \\
3290\end{array}$ & $\begin{array}{r}9208 \\
10208\end{array}$ \\
\hline 94 & 145404 & 7427 & 22530 & 3290 & 11208 \\
\hline 94 & 145435 & 9122 & 24985 & 3290 & 12218 \\
\hline 94 & 145465 & 12070 & 28356 & 3290 & 1208 \\
\hline 94 & 145496 & 14570 & 32271 & 3290 & 220 \\
\hline 94 & 145527 & 15832 & 34671 & 3290 & 323 \\
\hline 94 & 145557 & 16037 & 36053 & 3290 & 4228 \\
\hline 94 & 145616 & 17025 & 39440 & 3290 & 6208 \\
\hline 94 & 145653 & 18753 & 42264 & 3290 & 727 \\
\hline 94 & 145677 & 19712 & 44034 & 3290 & 8208 \\
\hline 94 & 145710 & 20278 & 45358 & 3290 & 9228 \\
\hline 94 & 145741 & 20344 & 46712 & 3290 & 10238 \\
\hline 94 & 145799 & 22354 & 51245 & 3290 & 12208 \\
\hline 3 & 144561 & 0 & 1128 & 1019 & 7317 \\
\hline 3 & 1. 44585 & 340 & 1878 & 1017 & 8247 \\
\hline 3 & 144619 & 730 & 2781 & 1019 & 92 \\
\hline 3 & 144652 & 864 & 3402 & 1019 & 10307 \\
\hline 3 & 144673 & 952 & 3827 & 1019 & 11207 \\
\hline 3 & 144711 & 1617 & 5083 & 1019 & 12287 \\
\hline 3 & 144725 & 2158 & 5884 & 1019 & 1117 \\
\hline 3 & 144745 & 2824 & 6875 & 1019 & 1317 \\
\hline 3 & 144758 & 3389 & 7679 & 1019 & 2137 \\
\hline 3 & 144800 & 4078 & 9024 & 1019 & 3277 \\
\hline 3 & 144818 & 4179 & 9378 & 1019 & 4147 \\
\hline 3 & 144844 & 4240 & 98.33 & 1019 & 5107 \\
\hline 3 & 144893 & 4583 & 10921 & 1019 & 6287 \\
\hline 3 & 144926 & 5017 & 11859 & 1019 & 7317 \\
\hline 3 & 144969 & 5569 & 13068 & 1019 & 9127 \\
\hline 3 & 144 & 5626 & 13533 & 1019 & 10117 \\
\hline 3 & 14505 & 6188 & 14906 & 1019 & 1237 \\
\hline 3 & & & & 1019 & 2148 \\
\hline 3 & 145 & 9237 & 21140 & 1019 & 6118 \\
\hline 3 & 145292 & 10065 & 22801 & 1019 & 7318 \\
\hline
\end{tabular}




\begin{tabular}{|c|c|c|c|c|c|}
\hline LOG * & J-IIATE & SUE MTK & M MTF & SQFT & IIATE \\
\hline 3 & $\begin{array}{l}145656 \\
146026\end{array}$ & $\begin{array}{l}15549 \\
21057\end{array}$ & $\begin{array}{l}34453 \\
46133\end{array}$ & $\begin{array}{l}1019 \\
1019\end{array}$ & $\begin{array}{l}73081 \\
8 \quad 482\end{array}$ \\
\hline $\begin{array}{l}3 \\
4\end{array}$ & $\begin{array}{l}146026 \\
144561\end{array}$ & $\begin{array}{r}21057 \\
0\end{array}$ & $\begin{array}{r}46133 \\
0\end{array}$ & $\begin{array}{l}1019 \\
1369\end{array}$ & $\begin{array}{l}8482 \\
73178\end{array}$ \\
\hline & $\begin{array}{l}144501 \\
144572\end{array}$ & 325 & 586 & 1369 & 81178 \\
\hline 4 & 144593 & 1030 & 1792 & 1369 & $9 \quad 178$ \\
\hline 4 & 144619 & 1582 & 2931 & 1369 & 92778 \\
\hline 4 & 144634 & 1728 & 3442 & 1369 & 101278 \\
\hline 4 & 144652 & 1927 & 4105 & 1369 & 103078 \\
\hline 4 & 144673 & 2155 & 4943 & 1369 & 112078 \\
\hline 4 & 144697 & 2916 & 6558 & 1369 & 121478 \\
\hline 4 & 144725 & 4204 & 8611 & 1369 & 11179 \\
\hline 4 & 144745 & 5180 & 10258 & 1369 & 13179 \\
\hline 4 & 144758 & 60.39 & 11512 & 1369 & 21379 \\
\hline 4 & 144780 & 6723 & 12797 & 1369 & 3779 \\
\hline 4 & 144800 & 7133 & 13776 & 1367 & .32779 \\
\hline 4 & 144844 & 7452 & 15071 & 1369 & 51079 \\
\hline 4 & 144893 & 8140 & 16472 & 1369 & 62879 \\
\hline 4 & 144926 & 9200 & 18221 & 1369 & 73179 \\
\hline 4 & 144969 & 10550 & 20536 & 1369 & 91279 \\
\hline 4 & 144998 & 10722 & 21377 & 1369 & 101179 \\
\hline 4 & 145051 & 11636 & 23156 & 1369 & 12379 \\
\hline 4 & 145124 & 13728 & 26178 & 1369 & 21480 \\
\hline 4 & 145242 & 15197 & 29154 & 1369 & 61180 \\
\hline 4 & 145292 & 16278 & 31802 & 1369 & 73180 \\
\hline 4 & 145656 & 22513 & 40725 & 1369 & 73081. \\
\hline 4 & 146026 & 30316 & 56332 & 1369 & 8482 \\
\hline 1 & 144684 & 43 & 431 & 1876 & $12 \quad 178$ \\
\hline 1 & 144697 & 543 & 1190 & 1876 & 121478 \\
\hline 1 & 144711 & 1193 & 2197 & 1876 & 122878 \\
\hline 1 & 144725 & 2551 & 3920 & 1876 & 11179 \\
\hline 1 & 144755 & 4504 & 6662 & 1876 & 21.079 \\
\hline 1 & 144758 & 4649 & 6895 & 1876 & 21379 \\
\hline 1 & 144780 & 5266 & 8026 & 1876 & 3779 \\
\hline 1 & 144786 & 5435 & 8348 & 1876 & 31379 \\
\hline 1 & 144800 & 5668 & 8888 & 1876 & 32779 \\
\hline 1 & 144844 & 6009 & 10176 & 1876 & 51079 \\
\hline 1 & 144854 & 6154 & 10564 & 1876 & 52079 \\
\hline 1 & 144893 & 6594 & 11705 & 1876 & 62879 \\
\hline 1 & 144926 & 7396 & 13135 & 1876 & 73179 \\
\hline 1 & 144969 & 8288 & 14829 & 1876 & 91279 \\
\hline 1 & 144998 & 8341 & 15420 & 1876 & 101179 \\
\hline 1 & 145079 & 9295 & 17482 & 1876 & 123179 \\
\hline 1 & 145242 & 14628 & 27212 & 1876 & 61180 \\
\hline 1 & 145292 & 15777 & 29112 & 1876 & 73180 \\
\hline 1 & 145657 & 22732 & 42702 & 1876 & 73181. \\
\hline 1 & 146026 & 29139 & 55743 & 1876 & 8482 \\
\hline 2 & 144684 & 34 & 502 & 1438 & 12178 \\
\hline 2 & 144697 & 429 & 1854 & 1438 & 121478 \\
\hline 2 & 144711 & 824 & 2794 & 1438 & 122878 \\
\hline 2 & 144725 & 1577 & 4043 & 1438 & 11179 \\
\hline 2 & 144745 & 2512 & 5653 & 1438 & 13179 \\
\hline 2 & 144758 & 3292 & 6888 & 1438 & 21379 \\
\hline 2 & 144780 & 3862 & 8228 & 1438 & 3779 \\
\hline & & & & & \\
\hline
\end{tabular}




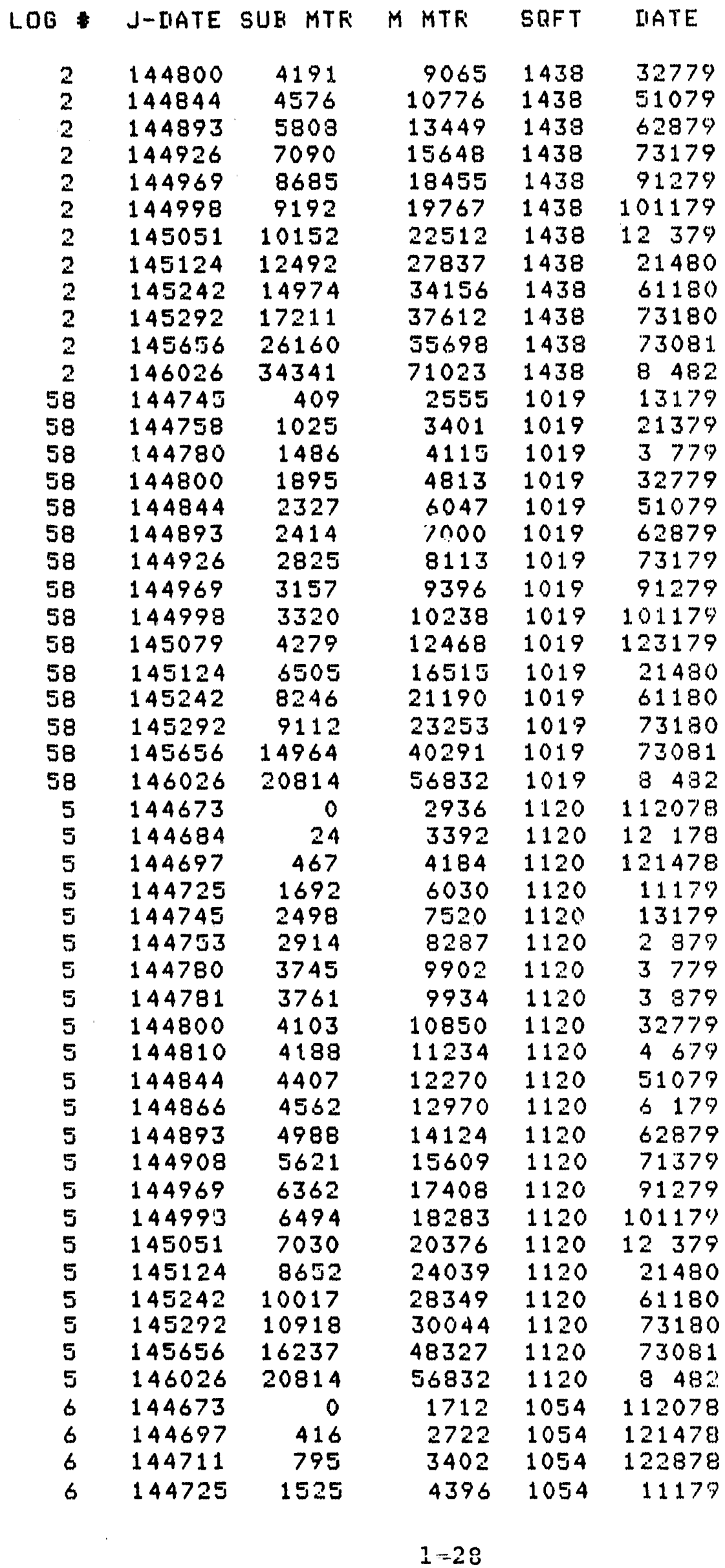




\begin{tabular}{|c|c|c|c|c|c|}
\hline LOG * & $J-$ IIATE & SUE MTK & M MTR & SRFT & IIATE \\
\hline 6 & 144745 & 2387 & 5639 & 1054 & 13179 \\
\hline $\begin{array}{l}6 \\
6\end{array}$ & $\begin{array}{l}144758 \\
144780\end{array}$ & $\begin{array}{l}3034 \\
3602\end{array}$ & $\begin{array}{l}6520 \\
7458\end{array}$ & $\begin{array}{l}1054 \\
1054\end{array}$ & $\begin{array}{l}21379 \\
3779\end{array}$ \\
\hline $\begin{array}{l}6 \\
6\end{array}$ & $\begin{array}{l}144800 \\
144844\end{array}$ & $\begin{array}{l}3913 \\
4184\end{array}$ & $\begin{array}{l}8142 \\
9031\end{array}$ & $\begin{array}{l}1054 \\
1054\end{array}$ & $\begin{array}{l}32779 \\
51079\end{array}$ \\
\hline 6 & 144890 & 4590 & 10108 & 1054 & 62579 \\
\hline $\begin{array}{l}6 \\
6\end{array}$ & $\begin{array}{l}144893 \\
144926\end{array}$ & $\begin{array}{l}4614 \\
5034\end{array}$ & $\begin{array}{l}10157 \\
11000\end{array}$ & $\begin{array}{l}1054 \\
1054\end{array}$ & $\begin{array}{l}62879 \\
73179\end{array}$ \\
\hline 6 & 144969 & 5608 & 12182 & 1054 & 71279 \\
\hline 6 & 144998 & 5706 & 12717 & 1054 & 101179 \\
\hline 6 & 145051 & 6316 & 14222 & 1054 & 12379 \\
\hline 6 & 145124 & 8060 & 17091 & 1054 & 21480 \\
\hline 6 & 145242 & 9382 & 20149 & 1054 & 61180 \\
\hline 6 & 145292 & 10133 & 21509 & 1054 & 73180 \\
\hline 6 & 145656 & 15390 & 31742 & 1054 & 73081 \\
\hline 6 & 146026 & 22014 & 46931 & 1054 & 8482 \\
\hline 57 & 144619 & 97 & 204 & 1054 & 92778 \\
\hline 57 & 144634 & 186 & 553 & 1054 & 101278 \\
\hline 57 & 144652 & 335 & 1000 & 1054 & 103078 \\
\hline 57 & 144673 & 457 & 1522 & 1054 & 112078 \\
\hline 57 & 144684 & 632 & 1887 & 1054 & 12178 \\
\hline 57 & 144697 & 977 & 2486 & 1054 & 121478 \\
\hline 57 & 144711 & 1366 & 3144 & 1054 & 122878 \\
\hline 57 & 144725 & 2016 & 4101 & 1054 & 11179 \\
\hline 57 & 144745 & 2751 & 5329 & 1054 & 13179 \\
\hline 57 & 144758 & 3347 & 6203 & 1054 & 21379 \\
\hline 57 & 144780 & 3768 & 7041 & 1054 & 3779 \\
\hline 57 & 144800 & 4009 & 7641 & 1054 & 32779 \\
\hline 57 & 144844 & 4161 & 8616 & 1054 & 51079 \\
\hline 57 & 144890 & 4837 & 10136 & 1054 & 62579 \\
\hline 57 & 144893 & 4889 & 10242 & 1054 & 62379 \\
\hline 57 & 144926 & 5579 & $\begin{array}{l}11396 \\
12815\end{array}$ & $\begin{array}{l}1054 \\
1054\end{array}$ & $\begin{array}{l}73179 \\
91279\end{array}$ \\
\hline 57 & 144969 & $\begin{array}{l}6392 \\
6769\end{array}$ & $\begin{array}{l}12815 \\
13771\end{array}$ & $\begin{array}{l}1054 \\
1054\end{array}$ & $\begin{array}{r}91279 \\
12379\end{array}$ \\
\hline 57 & 145051 & 6769 & $\begin{array}{l}1371 \\
15595\end{array}$ & $\begin{array}{l}1054 \\
1054\end{array}$ & \\
\hline 57 & 145124 & 7976 & 15575 & 1054 & 21480 \\
\hline 57 & 145242 & 9058 & 18293 & 1054 & 61180 \\
\hline 57 & 145292 & 9320 & 19084 & 1054 & 73180 \\
\hline 57 & 145656 & 14516 & 33931 & 1054 & 73081 \\
\hline 57 & 146026 & 18643 & 48834 & 1054 & 8482 \\
\hline 56 & 144619 & 73 & 277 & 1120 & 92778 \\
\hline 56 & 144634 & 155 & 740 & 1120 & 101278 \\
\hline 56 & 144652 & 282 & 1352 & 1120 & 103078 \\
\hline 56 & 144673 & 390 & 2063 & 1120 & 112078 \\
\hline 56 & 144711 & 1132 & 3805 & 1120 & 122878 \\
\hline 56 & 144725 & 1688 & 4806 & 1120 & 11178 \\
\hline 56 & 144745 & 2310 & 6169 & 1120 & 13179 \\
\hline 56 & 144780 & 3172 & $\begin{array}{l}8249 \\
9141\end{array}$ & $\begin{array}{l}1120 \\
1120\end{array}$ & $\begin{array}{l}3779 \\
32079\end{array}$ \\
\hline 56 & 144793 & $\begin{array}{l}3422 \\
3542\end{array}$ & $\begin{array}{r}9141 \\
10601\end{array}$ & $\begin{array}{l}1120 \\
1120\end{array}$ & $\begin{array}{l}32079 \\
51079\end{array}$ \\
\hline $\begin{array}{l}56 \\
56\end{array}$ & $\begin{array}{l}144844 \\
144856\end{array}$ & $\begin{array}{l}3542 \\
3564\end{array}$ & 10904 & 1120 & 52279 \\
\hline 56 & 144874 & 3723 & 11762 & 1120 & 6979 \\
\hline 56 & 144893 & 3970 & 12612 & 1120 & 62879 \\
\hline 56 & 144926 & 4718 & 14359 & 1120 & 73179 \\
\hline
\end{tabular}




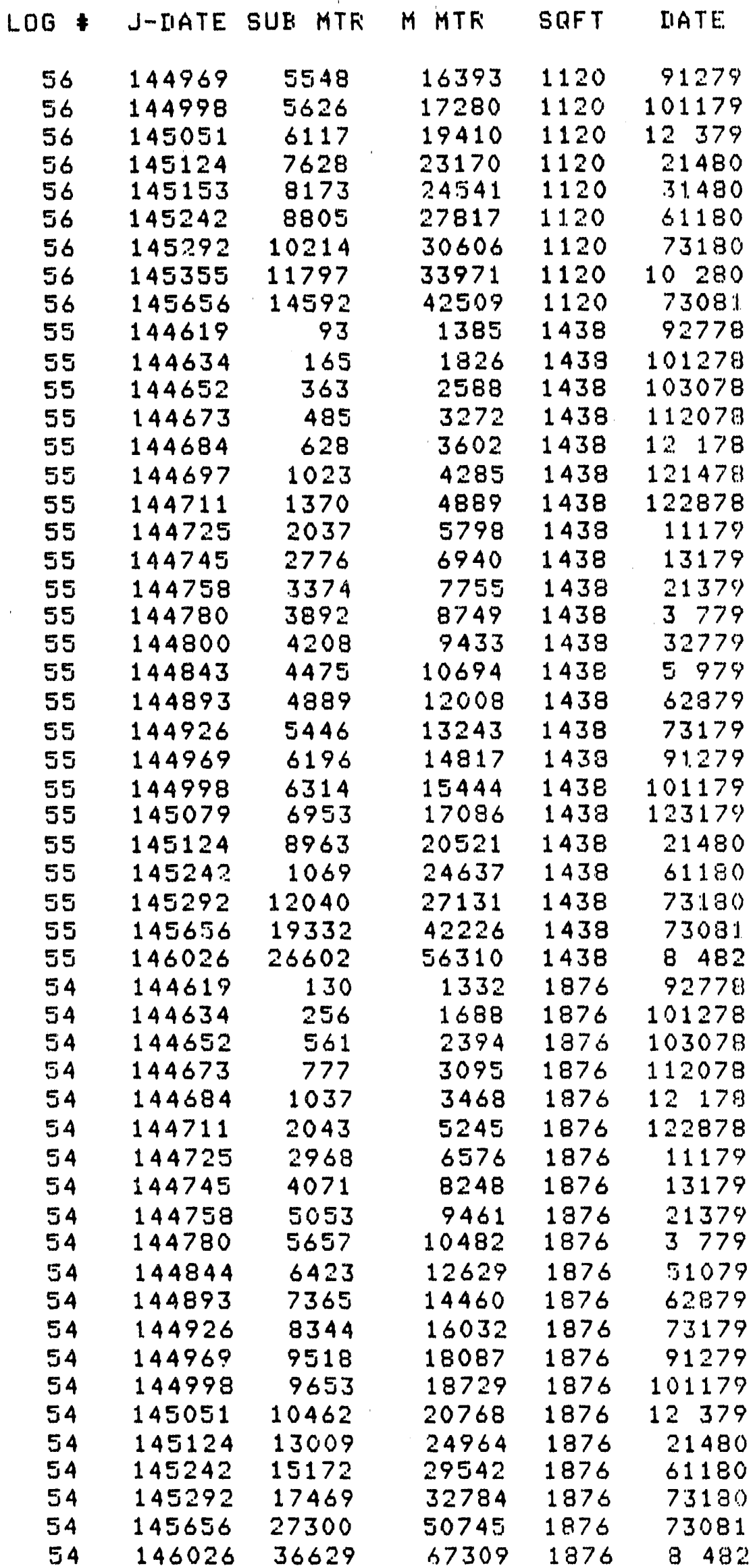

$1-30$ 


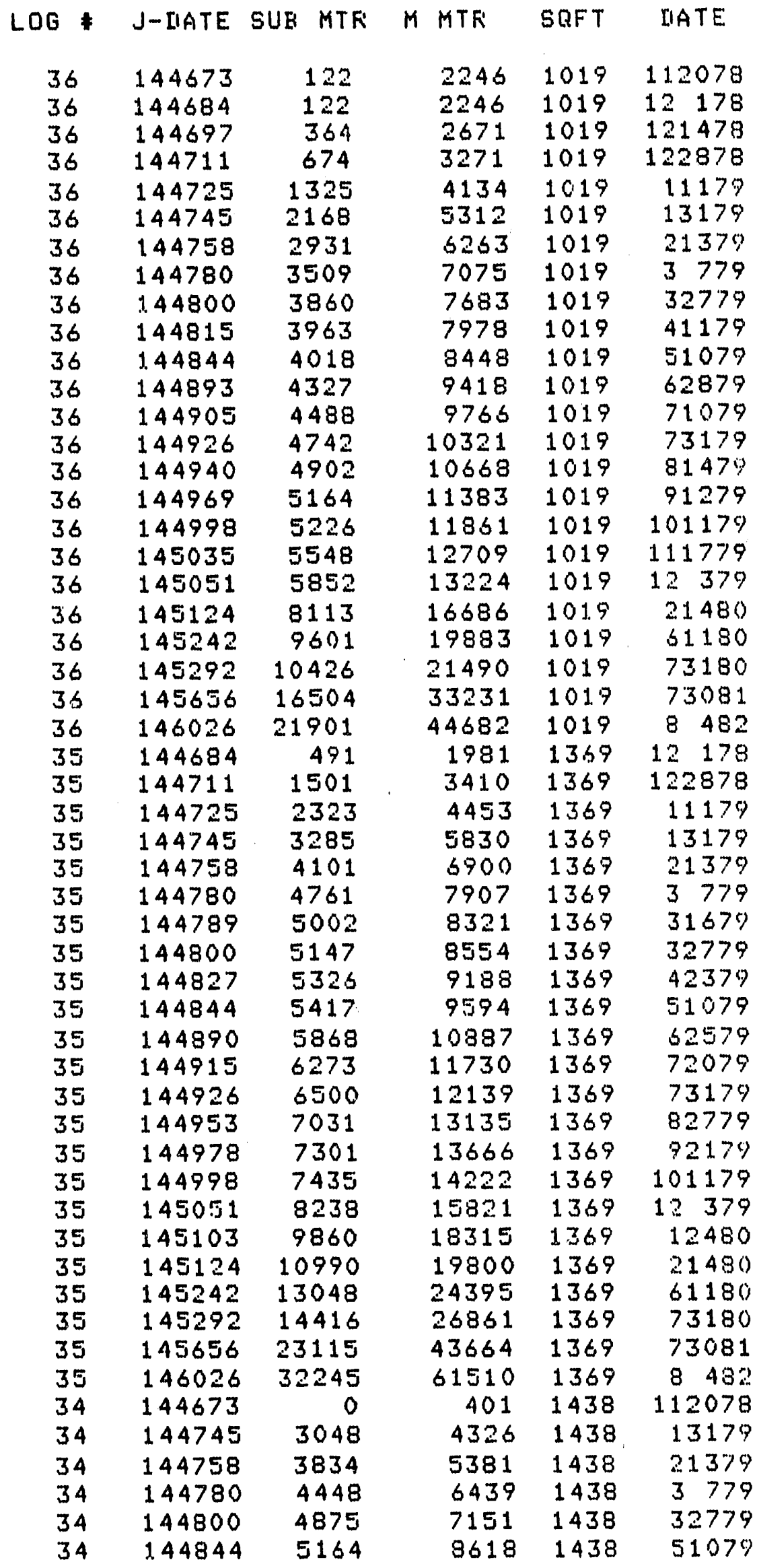




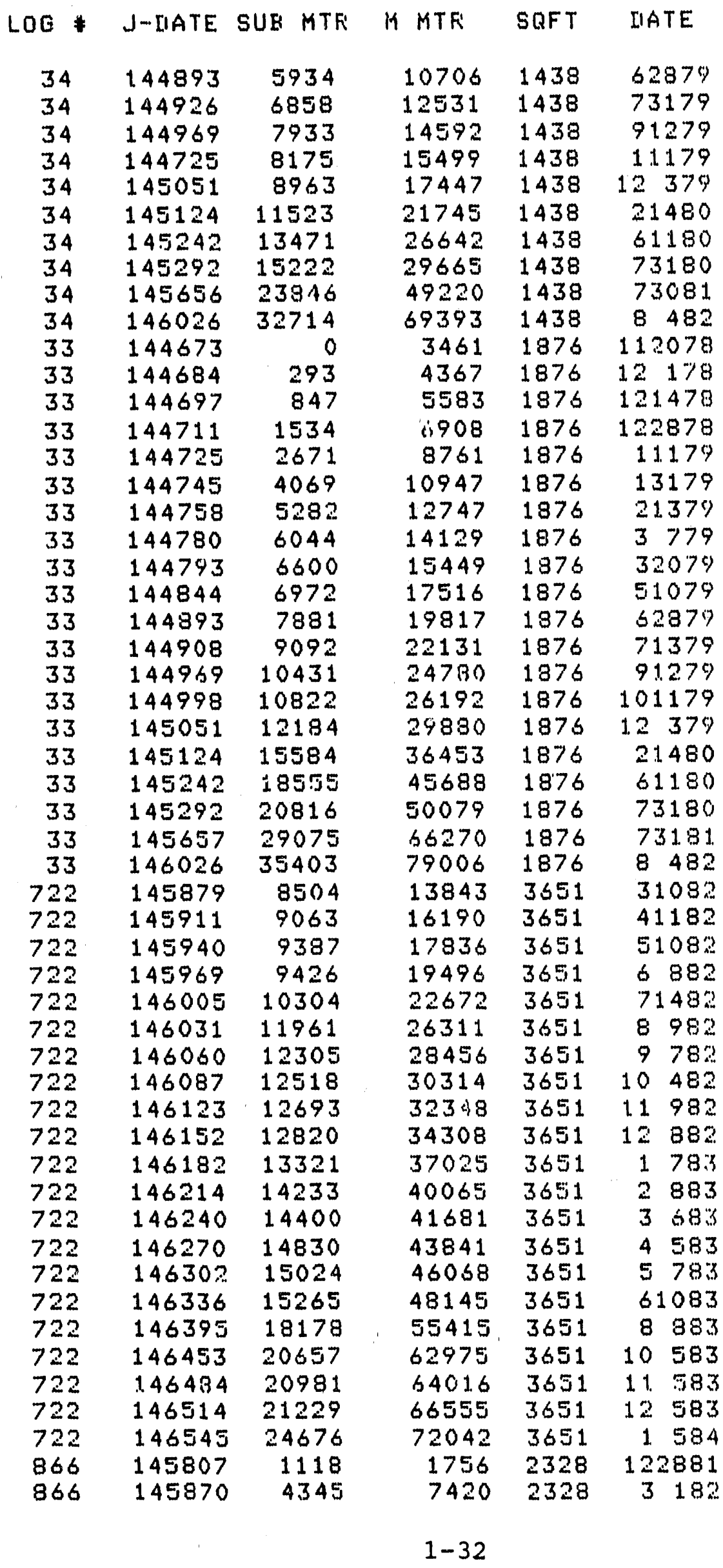




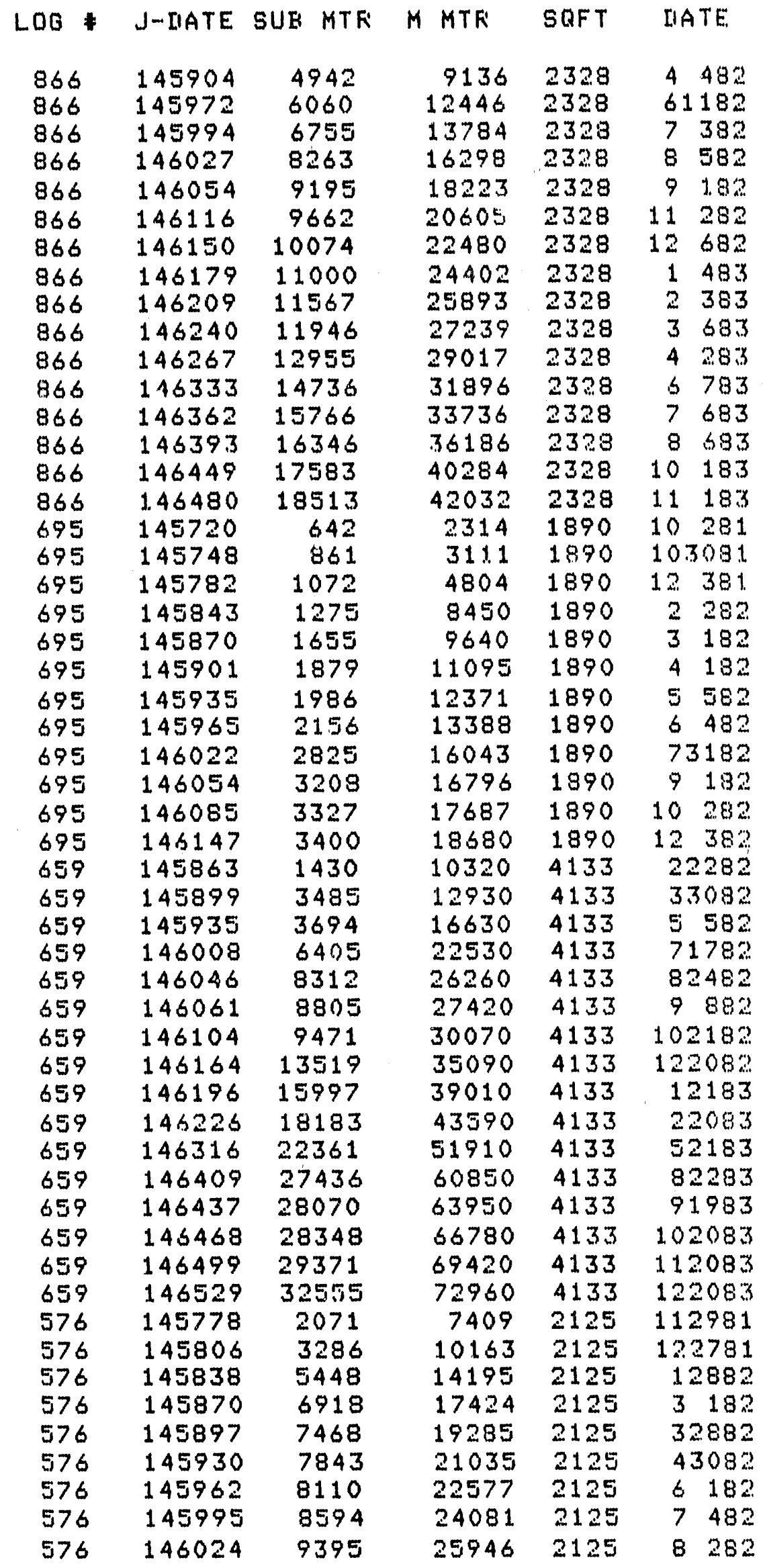




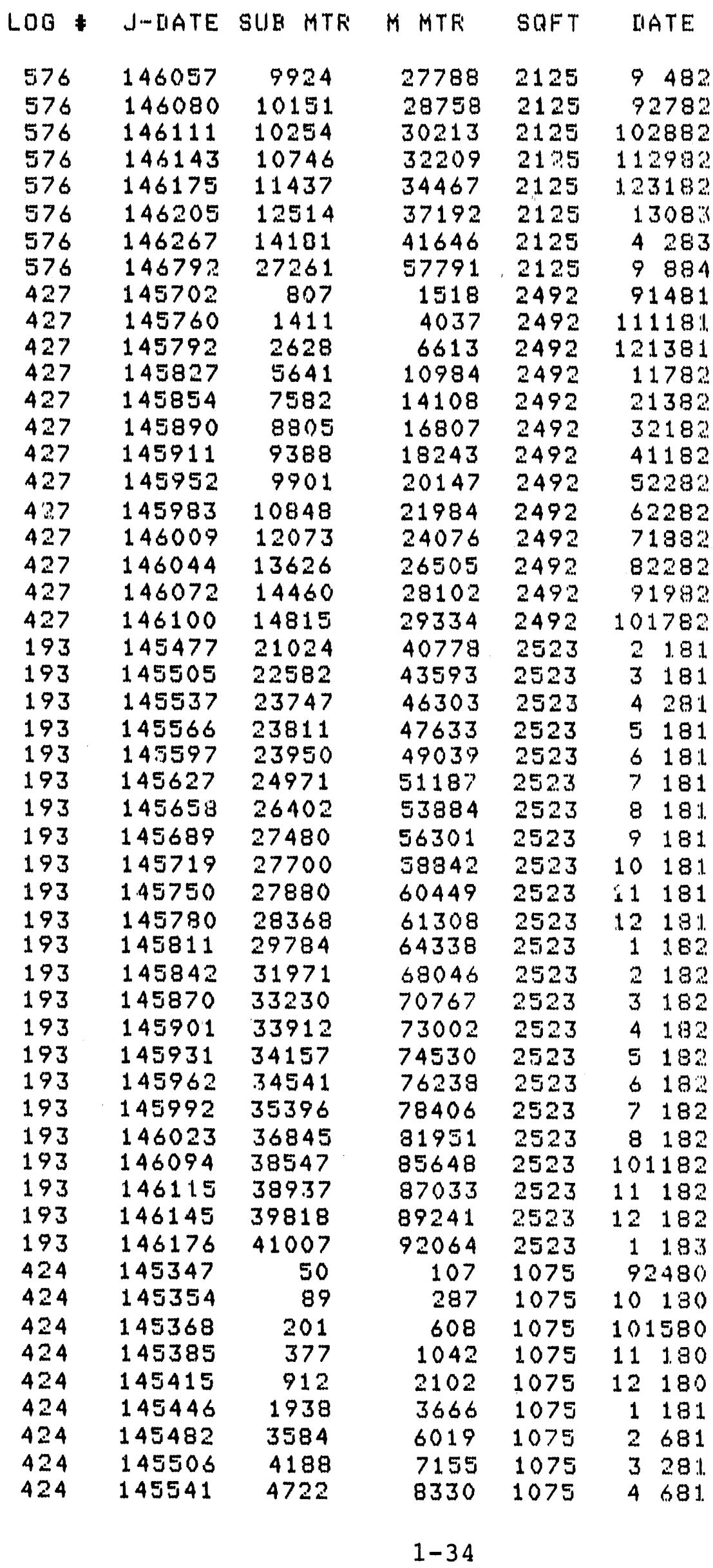




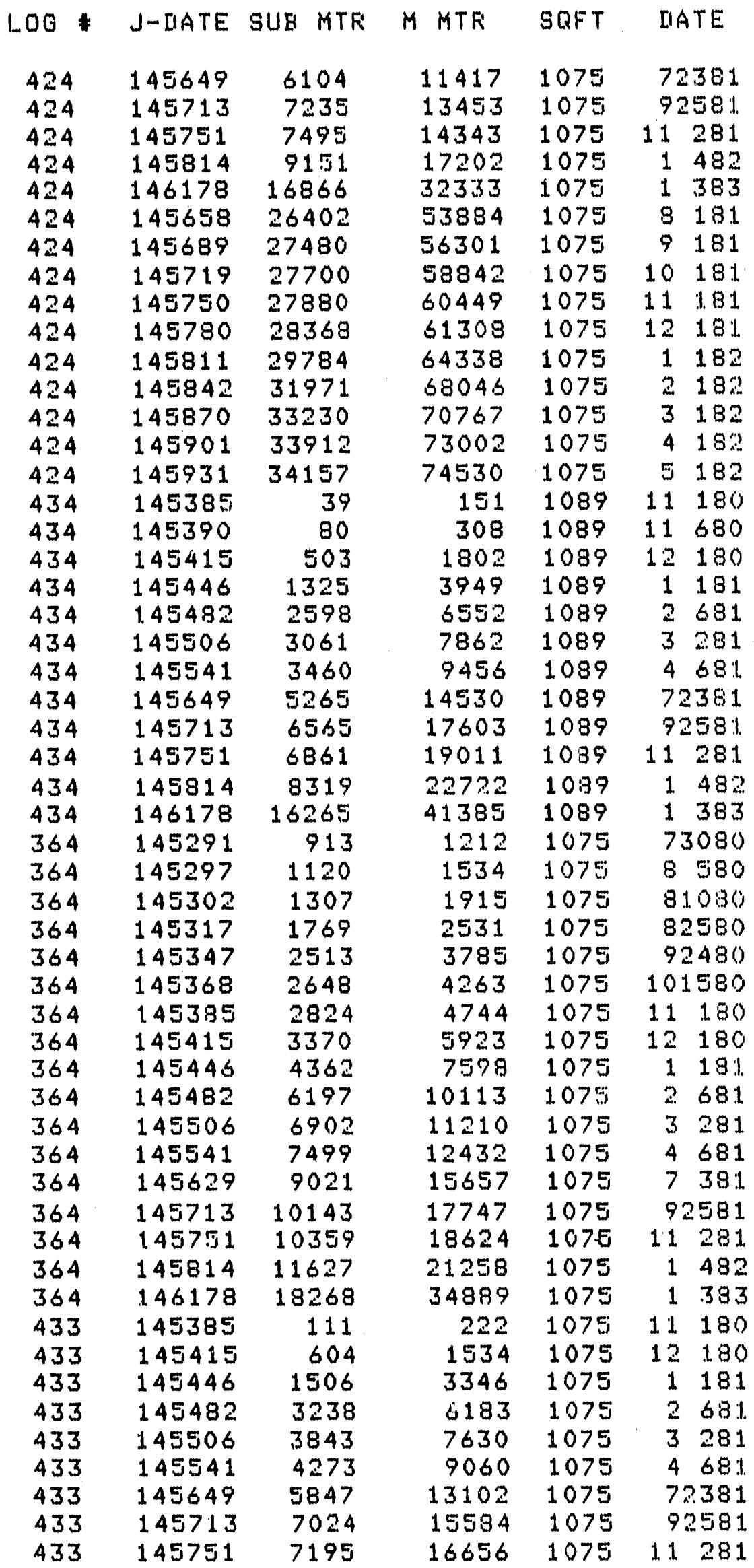




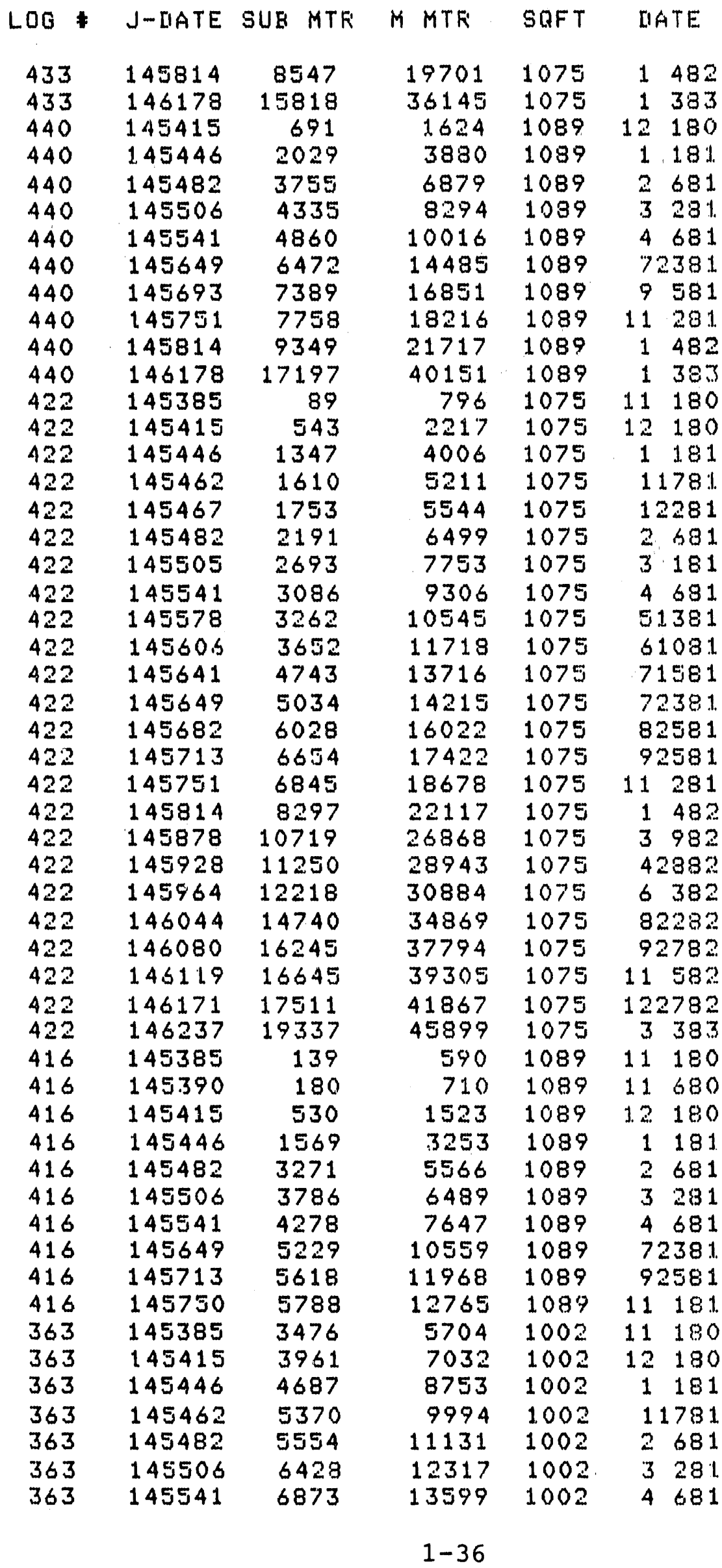




\begin{tabular}{|c|c|c|c|c|c|}
\hline LOG & $J-D A T E$ & SUB MTF & M MTK & SQF T & DATE. \\
\hline $\begin{array}{l}363 \\
363\end{array}$ & $\begin{array}{l}145649 \\
145713\end{array}$ & $\begin{array}{l}8247 \\
9194\end{array}$ & $\begin{array}{l}17259 \\
19570\end{array}$ & $\begin{array}{l}1002 \\
1002\end{array}$ & $\begin{array}{l}72381 \\
92581\end{array}$ \\
\hline 363 & 145751 & 9351 & 20548 & 1002 & 11281 \\
\hline 363 & 145814 & 10478 & 23254 & 1002 & 1482 \\
\hline 363 & 146178 & 16482 & 36502 & 1002 & 1383 \\
\hline 7 & 144967 & 462 & 640 & 1820 & 91079 \\
\hline 7 & 144393 & 903 & 2160 & 1820 & 10679 \\
\hline 7 & 145052 & 2526 & 6440 & 1820 & 12479 \\
\hline 7 & 145056 & 2660 & 6760 & 1820 & 12879 \\
\hline 7 & 145084 & 4071 & 9150 & 1820 & 1580 \\
\hline 7 & 145113 & 5559 & 12120 & 1820 & 2380 \\
\hline 7 & 145175 & 8349 & 17600 & 1820 & 4580 \\
\hline 7 & 145210 & 8692 & 19600 & 1820 & 51080 \\
\hline $\begin{array}{l}7 \\
7\end{array}$ & $\begin{array}{l}145220 \\
145237\end{array}$ & $\begin{array}{l}8835 \\
9382\end{array}$ & $\begin{array}{l}20160 \\
21520\end{array}$ & $\begin{array}{l}1820 \\
1820\end{array}$ & $\begin{array}{l}52080 \\
6 \quad 680\end{array}$ \\
\hline 7 & 145329 & 13341 & 28680 & 1820 & 9380 \\
\hline 7 & 145420 & 15329 & 35160 & 1820 & 12680 \\
\hline 8 & 144941 & 956 & 1286 & 1720 & 81579 \\
\hline 8 & 144967 & 1789 & 3000 & 1720 & 91079 \\
\hline 8 & 144982 & 2019 & 3760 & 1720 & 92379 \\
\hline 8 & 145052 & 3792 & 8320 & 1720 & 12479 \\
\hline 8 & 145079 & 5096 & 10920 & 1720 & 123179 \\
\hline 8 & 145117 & 7176 & 14720 & 1720 & 2780 \\
\hline 8 & 145171 & 9419 & 19400 & 1720 & 4180 \\
\hline 8 & 145220 & 10035 & 21840 & 1720 & 52080 \\
\hline 8 & 145277 & 11910 & 25480 & 1720 & 71680 \\
\hline 8 & 145304 & 13016 & 27280 & 1720 & 81280 \\
\hline 8 & 145331 & 14047 & 29000 & 1720 & 9880 \\
\hline 9 & 144972 & 3955 & 1820 & 4075 & 91579 \\
\hline 9 & 145013 & 4151 & 3870 & 4075 & 102679 \\
\hline 9 & 145044 & 4748 & 6030 & 4075 & 112679 \\
\hline 9 & 145074 & 6257 & 9990 & 4075 & 122679 \\
\hline 9 & 145105 & 8326 & 13660 & 4075 & 12680 \\
\hline 9 & 145173 & 11505 & 20520 & 4075 & 4380 \\
\hline 9 & 145194 & 12024 & 22100 & 4075 & 42480 \\
\hline 9 & 145306 & 17049 & 32670 & 4075 & 31480 \\
\hline 10 & 145104 & 3716 & 7030 & 2846 & 12580 \\
\hline 10 & 145122 & 5612 & 10300 & 2846 & 21280 \\
\hline 10 & 145188 & 8400 & 17410 & 2846 & 41880 \\
\hline 10 & 145256 & 10160 & 23010 & 2846 & 6258() \\
\hline 10 & 145285 & 12202 & 26620 & 2846 & 72480 \\
\hline 10 & 145310 & 13596 & 29140 & 2846 & 81880 \\
\hline 10 & 145345 & 15333 & 32780 & 2846 & 92280 \\
\hline 10 & 145374 & 15710 & 34660 & 2846 & 102130 \\
\hline 10 & 145404 & 16672 & 37310 & 2846 & 112080 \\
\hline 10 & 1454.34 & 18431 & 41070 & 2846 & 122080 \\
\hline 10 & 145464 & 22221 & 47000 & 2846 & 11981 \\
\hline 10 & 145521 & 25742 & 54560 & 2846 & 31781 \\
\hline 10 & 145553 & 26258 & 57910 & 2846 & 41881 \\
\hline 10 & 145583 & 26348 & 58540 & 2346 & 51881 \\
\hline 10 & 145617 & 27189 & 61130 & 2846 & 62181 \\
\hline 11 & 144969 & 1716 & 3666 & 2373 & 91279 \\
\hline 11 & 144999 & 1883 & 4639 & 2373 & 101279 \\
\hline
\end{tabular}




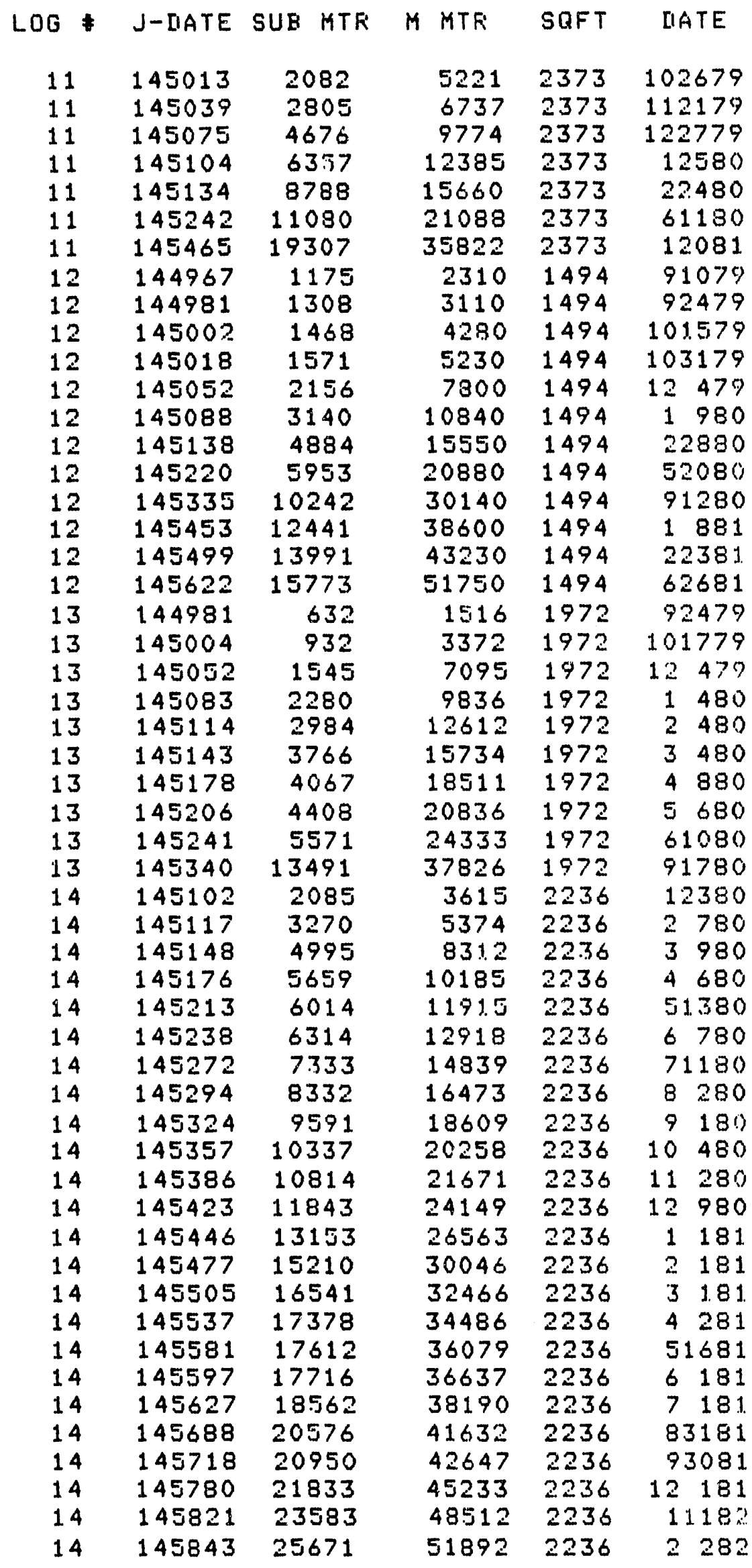




\begin{tabular}{|c|c|c|c|c|c|}
\hline LOG * & $J$ JIIATE & SUB MTK & $M M T F$ & SRFT & IIATE \\
\hline 568 & 145497 & 2711 & 4252 & 1620 & 22181 \\
\hline $\begin{array}{l}568 \\
568 \\
568 \\
568 \\
568 \\
568 \\
568\end{array}$ & $\begin{array}{l}145526 \\
145588 \\
145619 \\
145649 \\
145682 \\
145712 \\
145745\end{array}$ & $\begin{array}{l}3299 \\
3601 \\
4147 \\
4822 \\
5580 \\
6086 \\
6089\end{array}$ & $\begin{array}{r}5739 \\
7578 \\
9098 \\
10509 \\
12296 \\
13750 \\
14821\end{array}$ & $\begin{array}{l}1620 \\
1620 \\
1620 \\
1620 \\
1620 \\
1620 \\
1620\end{array}$ & $\begin{array}{r}32281 \\
52381 \\
62381 \\
72381 \\
82581 \\
92481 \\
102781\end{array}$ \\
\hline 568 & 145781 & $\begin{array}{l}6615 \\
7732\end{array}$ & 16597 & 1620 & $\begin{array}{r}12281 \\
1582\end{array}$ \\
\hline $\begin{array}{l}568 \\
568\end{array}$ & $\begin{array}{l}145815 \\
145842\end{array}$ & $\begin{array}{l}7732 \\
8994 \\
4070\end{array}$ & $\begin{array}{r}19169 \\
21710 \\
7171\end{array}$ & $\begin{array}{l}1620 \\
1620 \\
1864\end{array}$ & $\begin{array}{l}1582 \\
2182 \\
21980\end{array}$ \\
\hline $\begin{array}{l}15 \\
15\end{array}$ & $\begin{array}{l}145129 \\
145159\end{array}$ & $\begin{array}{l}4070 \\
4771\end{array}$ & $\begin{array}{l}7171 \\
8753\end{array}$ & $\begin{array}{l}1864 \\
1864\end{array}$ & $\begin{array}{l}21.980 \\
32080\end{array}$ \\
\hline 15 & 145173 & 4859 & 9257 & 1864 & 4380 \\
\hline 15 & 145203 & 5031 & 10278 & 1864 & 5380 \\
\hline 15 & 145234 & 5251 & 11429 & 1864 & 6380 \\
\hline $\begin{array}{l}15 \\
15\end{array}$ & $\begin{array}{l}145264 \\
145294\end{array}$ & $\begin{array}{l}5981 \\
7296\end{array}$ & $\begin{array}{l}13073 \\
15406\end{array}$ & $\begin{array}{l}1864 \\
1864\end{array}$ & $\begin{array}{ll}7 & 380 \\
8 & 280\end{array}$ \\
\hline 15 & 145326 & 8.397 & 17497 & 1864 & 9380 \\
\hline 15 & 145356 & 8978 & 18939 & 1864 & 10380 \\
\hline 15 & 145387 & 9184 & 19895 & 1864 & 11380 \\
\hline 15 & 145479 & 12825 & 25554 & 1864 & 2381 \\
\hline 15 & 145507 & 13863 & 27295 & 18.44 & 3381 \\
\hline 15 & 145801 & 19925 & 40012 & 1864 & 122281 \\
\hline 390 & 145236 & 28 & 0 & 1388 & 6580 \\
\hline 390 & 145290 & 786 & 2020 & 1388 & 72980 \\
\hline 390 & 145310 & 1080 & 2692 & 1338 & 81880 \\
\hline 390 & 145342 & 1533 & 3553 & 1388 & 91980 \\
\hline 390 & 145372 & 1746 & 4220 & 1388 & 101780 \\
\hline 390 & 145403 & 2009 & 5220 & 1388 & 111980 \\
\hline 390 & 145437 & 2592 & 6580 & 1388 & 122380 \\
\hline 390 & 145465 & 3514 & 8180 & 1388 & 12081 \\
\hline 390 & 145500 & 4445 & 10000 & 1388 & 22481 \\
\hline 390 & 145523 & 4838 & 10940 & 1388 & 31981 \\
\hline 390 & 145556 & 5077 & 11990 & 1388 & 42181 \\
\hline 390 & 145617 & 5559 & 12880 & 1388 & 52181 \\
\hline 390 & 145646 & 6051 & 14580 & 1388 & 72081 \\
\hline 390 & 145264 & 5981 & 13073 & 1388 & 7380 \\
\hline 390 & 145294 & 7296 & 15406 & 1388 & 8280 \\
\hline 390 & 145326 & 8397 & 17497 & 1388 & 9380 \\
\hline 390 & 145356 & 8979 & 1.8939 & 1388 & 10380 \\
\hline 390 & 145387 & 9184 & 19895 & 1388 & 11380 \\
\hline 390 & 145479 & 12825 & 25554 & 1388 & 2381 \\
\hline 390 & 145507 & 13863 & 27295 & 1388 & 3381 \\
\hline 390 & 145801 & 19925 & 40012 & 1388 & 122281 \\
\hline 16 & 144933 & 778 & 1527 & 1788 & 8779 \\
\hline 16 & 144967 & 1005 & 2502 & 1788 & 91079 \\
\hline 16 & 145087 & 1693 & 4229 & 1788 & 1880 \\
\hline 16 & 145118 & 1957 & 5499 & 1788 & 2880 \\
\hline 16 & 145147 & 2219 & 6629 & 1788 & 3880 \\
\hline 16 & 145178 & 2395 & 7188 & 1788 & 4880 \\
\hline 16 & 145269 & 2922 & 8640 & 1788 & 7880 \\
\hline 16 & 145300 & 3178 & 10131 & 1798 & 8880 \\
\hline
\end{tabular}




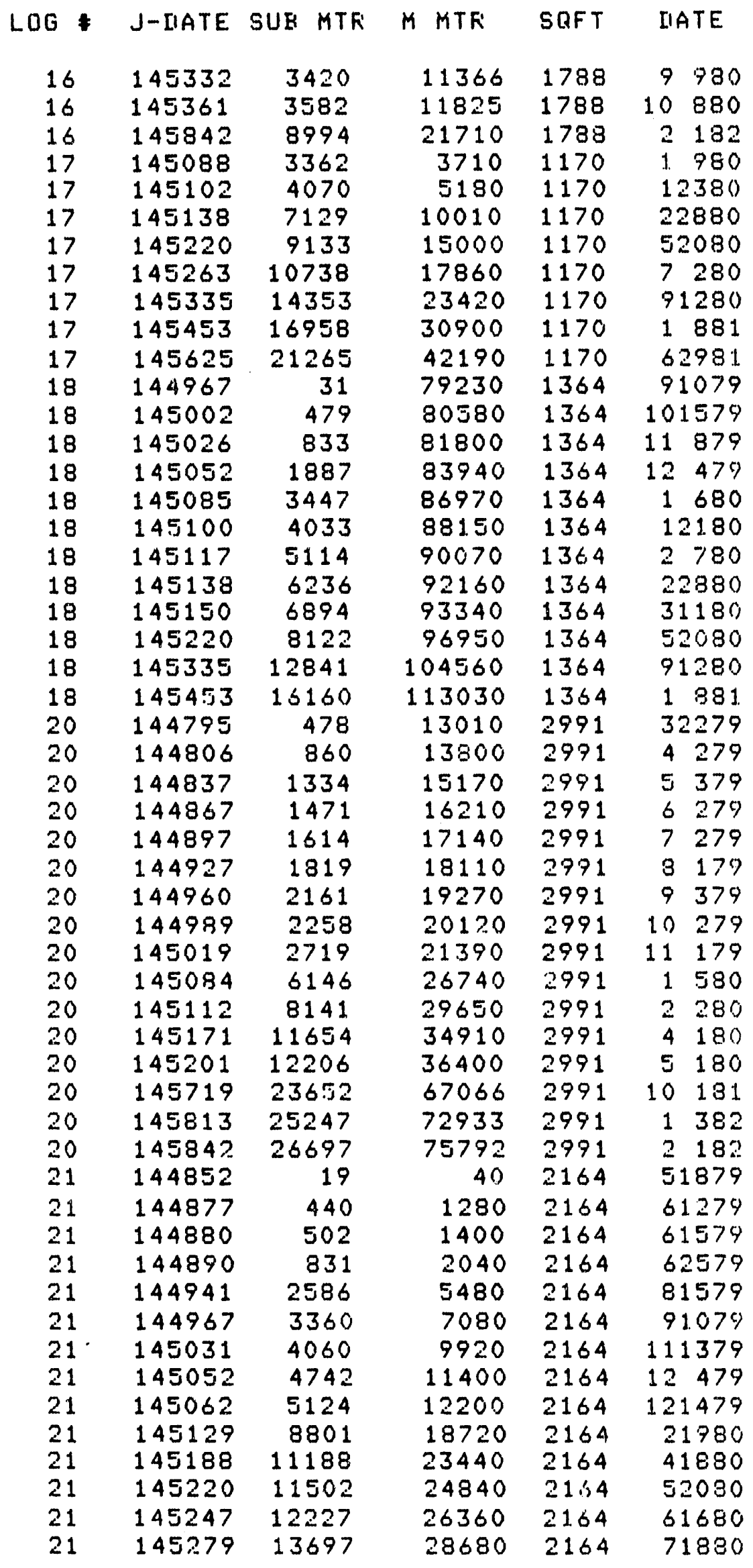




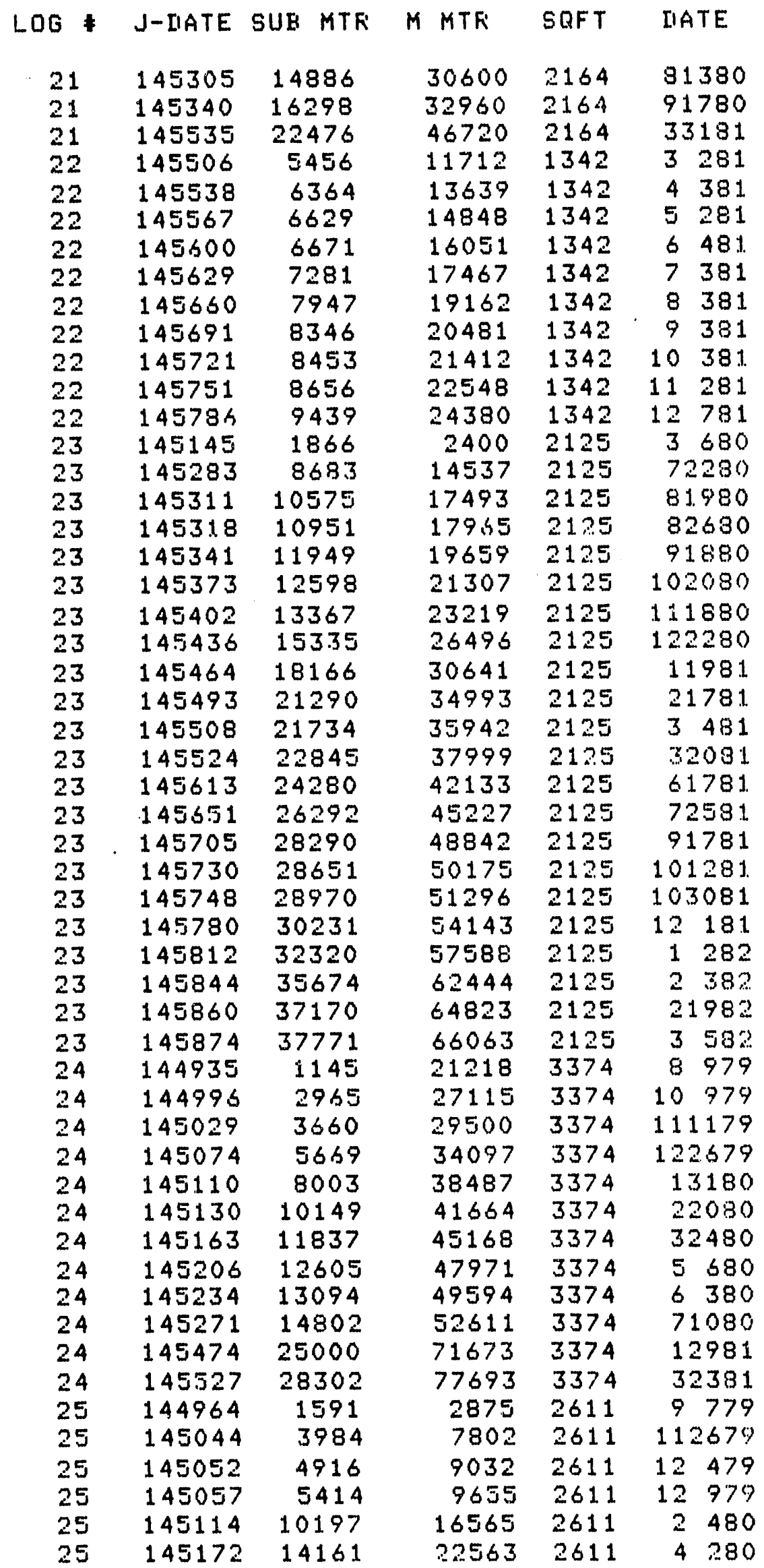




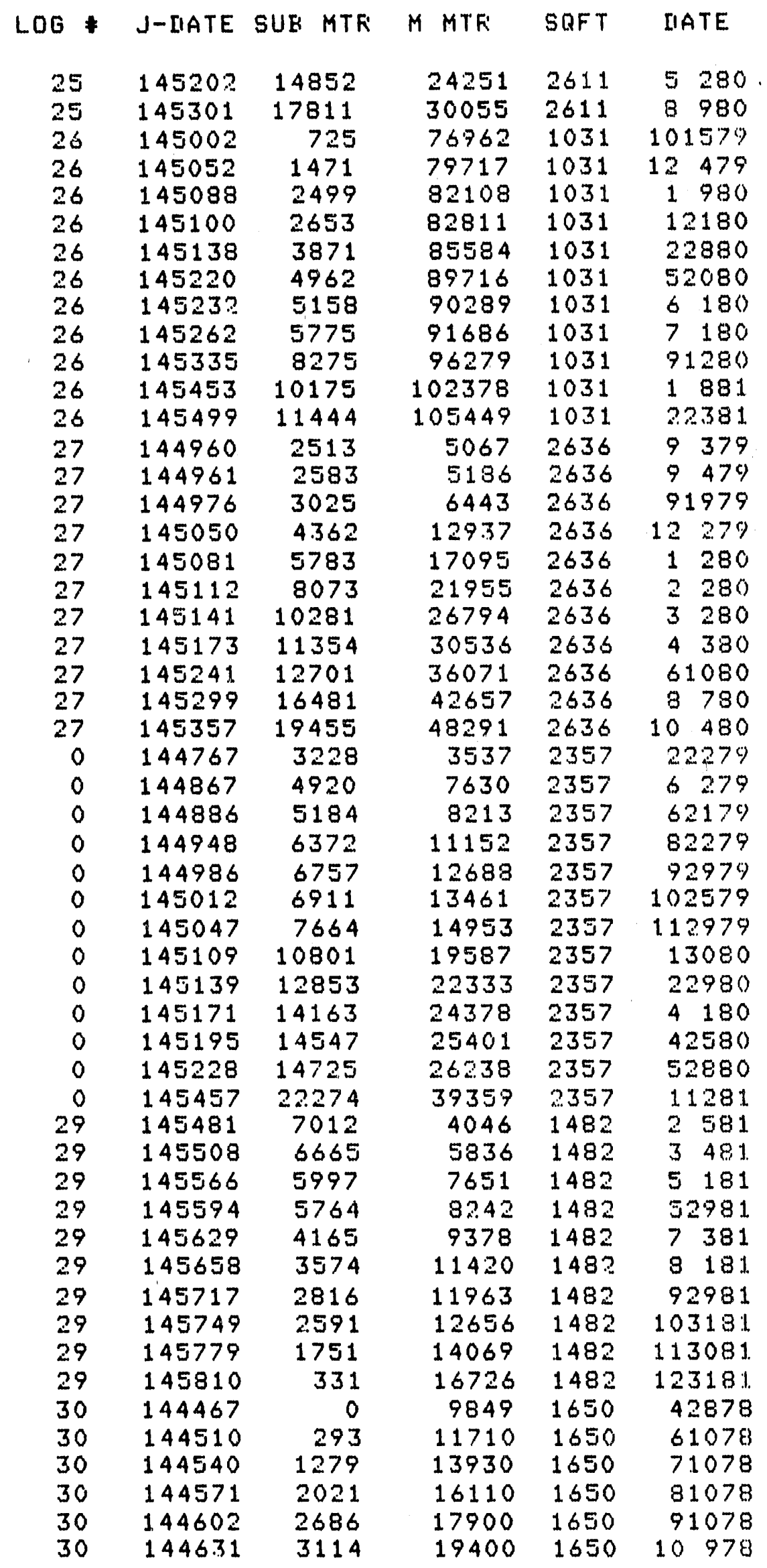




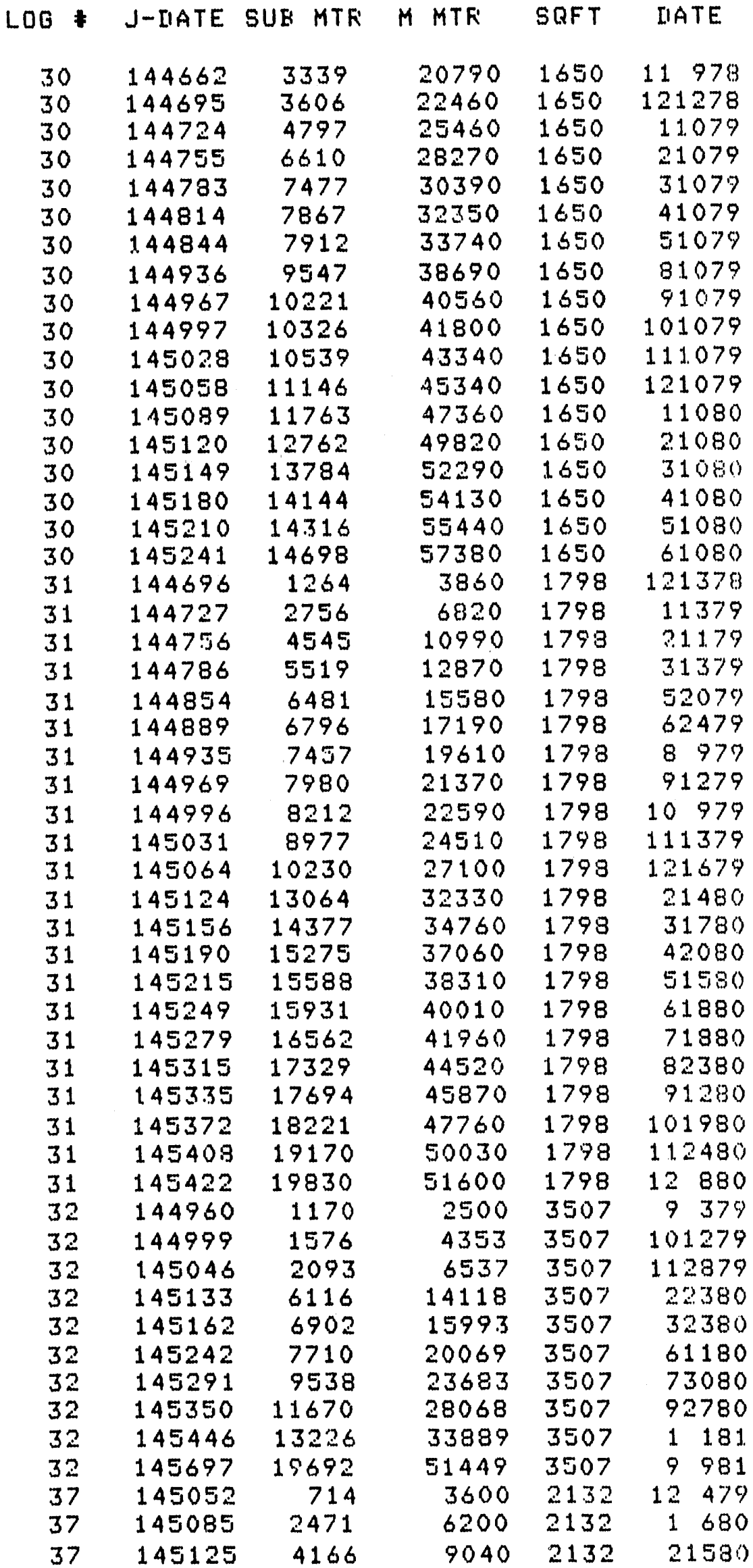

$1-43$ 


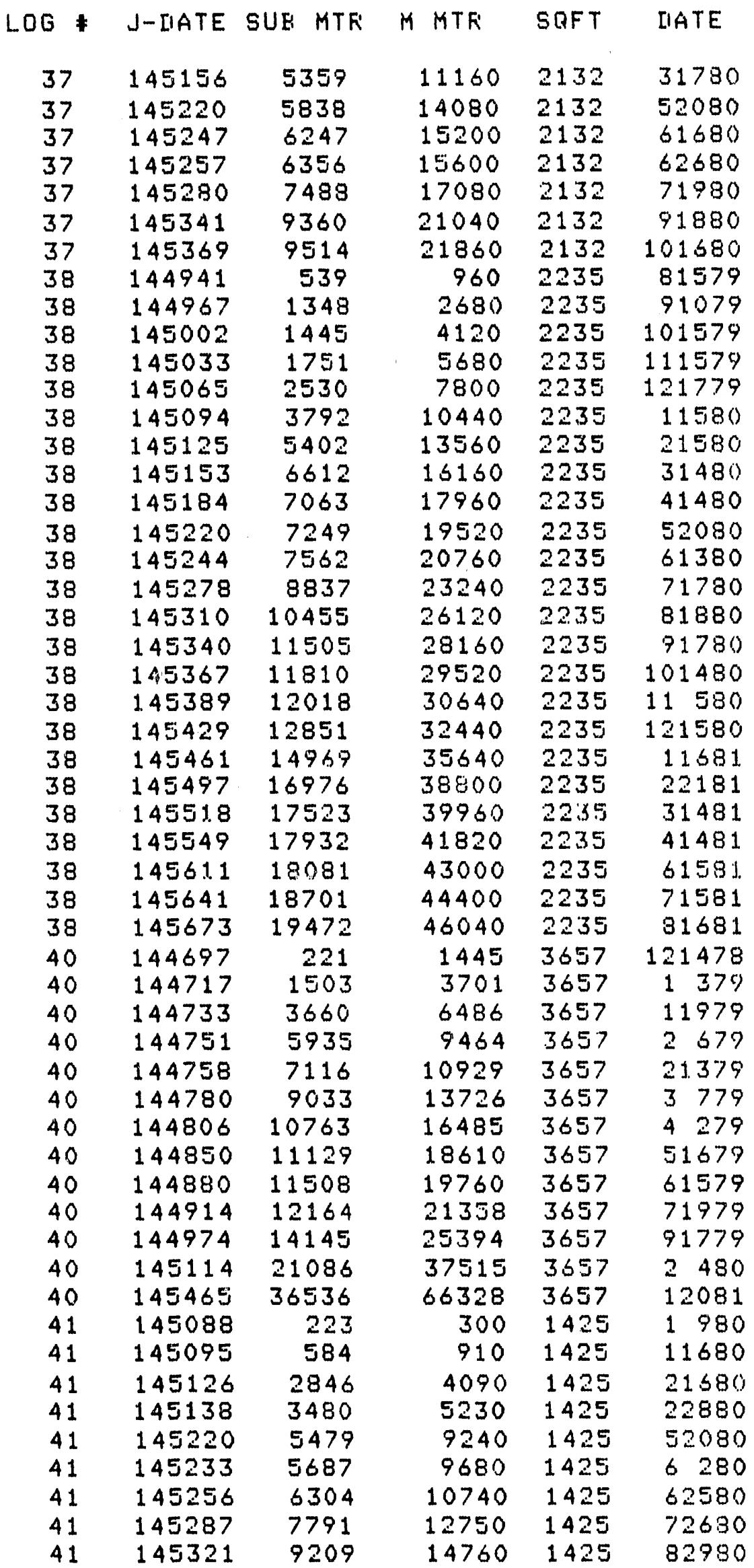




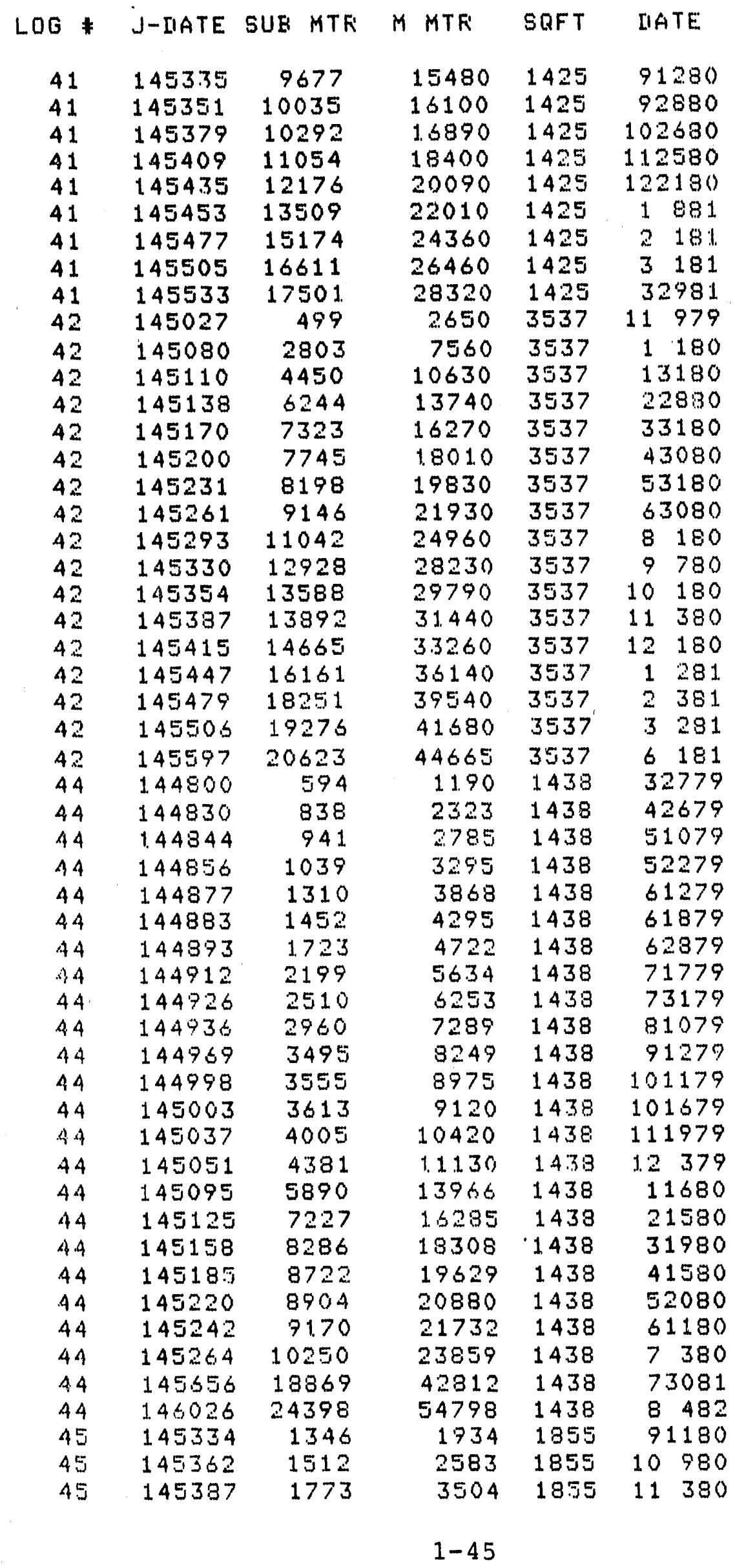




\begin{tabular}{|c|c|c|c|c|c|}
\hline G & $J-[I A T E$. & 21 & M MTE & SQFT & IIATE \\
\hline $\begin{array}{l}45 \\
45 \\
45 \\
45\end{array}$ & $\begin{array}{l}145432 \\
145476 \\
145516 \\
145549\end{array}$ & $\begin{array}{l}2807 \\
4528 \\
5822 \\
6154\end{array}$ & $\begin{array}{r}6162 \\
8969 \\
11562 \\
12857\end{array}$ & $\begin{array}{l}1855 \\
1855 \\
1855 \\
1855\end{array}$ & $\begin{array}{r}121880 \\
13181 \\
31281 \\
41481\end{array}$ \\
\hline $\begin{array}{l}45 \\
45\end{array}$ & $\begin{array}{l}145581 \\
145612\end{array}$ & $\begin{array}{l}6193 \\
6614\end{array}$ & $\begin{array}{l}13631 \\
14766\end{array}$ & $\begin{array}{l}1855 \\
1855\end{array}$ & $\begin{array}{l}51681 \\
61681\end{array}$ \\
\hline 45 & $\begin{array}{l}145656 \\
146026\end{array}$ & $\begin{array}{r}7514 \\
14399\end{array}$ & $\begin{array}{l}16817 \\
32978\end{array}$ & $\begin{array}{l}1855 \\
1855\end{array}$ & $\begin{array}{l}73081 \\
8 \quad 482\end{array}$ \\
\hline 46 & 145292 & 700 & 1458 & 1438 & 73180 \\
\hline A6 & 145330 & 1220 & 2720 & 1438 & 9780 \\
\hline AS & 145336 & 1244 & 2845 & 1438 & 71380 \\
\hline 46 & 145414 & 1939 & 5341 & 1438 & 113080 \\
\hline 46 & 145448 & 2872 & 7392 & 1438 & $138 \mathrm{~L}$ \\
\hline 16 & 145476 & 4107 & 9499 & 1438 & 13181 \\
\hline 46 & 145496 & 4744 & 10715 & 1438 & 22081 \\
\hline 46 & 145521 & 5053 & $1180 \%$ & 1438 & 31781 \\
\hline 46 & 145547 & 5225 & 12567 & 1438 & 41281 \\
\hline 46 & 1. 45568 & 5245 & 13095 & 1438 & 5381 \\
\hline $4 \leq$ & 145609 & 5348 & 14111 & 1438 & 61381 \\
\hline 46 & 145636 & 5556 & 14868 & 1438 & 71081 \\
\hline 46 & 145656 & 5810 & 15505 & 1438 & 73081 \\
\hline 46 & 146026 & 9995 & 28507 & 1438 & 8482 \\
\hline 46 & 145656 & 18867 & 42812 & 1438 & 73031 \\
\hline 46 & 146026 & 24398 & 54798 & 1438 & 8482 \\
\hline 47 & 144954 & 0 & 0 & 2259 & 8287 \\
\hline 47 & 144962 & 303 & 417 & 2259 & 9575 \\
\hline 47 & 144963 & 350 & 475 & 2259 & 9679 \\
\hline 47 & 145069 & 3090 & 5971 & 2259 & 122179 \\
\hline 47 & 984 & 3987 & 7392 & 2259 & 1580 \\
\hline 47 & 145116 & 6196 & 10833 & 2259 & 2680 \\
\hline 47 & 145145 & 8366 & 141.87 & 2259 & 3680 \\
\hline 47 & 145175 & 9218 & 16153 & 2259 & 4580 \\
\hline 47 & 145205 & 9650 & 17564 & 2259 & 5580 \\
\hline 47 & 145240 & 10497 & 19402 & 2259 & 6980 \\
\hline $\begin{array}{l}47 \\
47\end{array}$ & $\begin{array}{l}145300 \\
145328\end{array}$ & $\begin{array}{l}13495 \\
14904\end{array}$ & $\begin{array}{l}23907 \\
26045\end{array}$ & $\begin{array}{l}2259 \\
2259\end{array}$ & $\begin{array}{ll}8 & 330 \\
9 & 580\end{array}$ \\
\hline 47 & 145389 & 16034 & 28760 & 2259 & 11580 \\
\hline 47 & 14 & 17038 & 30677 & 2259 & 12580 \\
\hline 49 & 145497 & 4046 & 6366 & 2727 & 22181 \\
\hline 49 & 13 & 4085 & 6915 & 2727 & 398 \\
\hline 19 & 34 & 4163 & 8006 & 2727 & 498 \\
\hline 49 & 145573 & 4321 & 7158 & 2727 & 588 \\
\hline 49 & 145605 & 4953 & 10379 & 2727 & 698 \\
\hline 49 & 145636 & 5157 & 12005 & 2727 & 7108 \\
\hline 49 & 145667 & 6112 & 14284 & 2727 & 8108 \\
\hline 49 & 145697 & 6495 & 15679 & 2727 & 998 \\
\hline 49 & 145728 & 6717 & 16892 & 2727 & 10108 \\
\hline 49 & 145760 & 7290 & 18689 & 2727 & 11118 \\
\hline 49 & 14 & 7677 & 20215 & 2727 & 1228 \\
\hline $\begin{array}{l}49 \\
49\end{array}$ & $\begin{array}{l}145836 \\
145854\end{array}$ & $\begin{array}{l}8181 \\
8421\end{array}$ & $\begin{array}{l}22737 \\
23671\end{array}$ & $\begin{array}{l}2727 \\
2727\end{array}$ & $\begin{array}{l}1268 \\
2138\end{array}$ \\
\hline 49 & 145876 & 8661 & 25143 & 2727 & 378 \\
\hline 45 & 145914 & 8857 & 26187 & 2727 & 4148 \\
\hline
\end{tabular}




\begin{tabular}{|c|c|c|c|c|c|}
\hline LOQ * & $J-$ IIATE & SUE MTK & M MTR & SRFT & IIATE \\
\hline 49 & 145940 & 9110 & 27457 & 2727 & 51082 \\
\hline 49 & 145971 & 9356 & 28778 & 2727 & 31082 \\
\hline 49 & 146007 & 9969 & 30495 & 2727 & 71682 \\
\hline 47 & 146032 & 10863 & 32281 & 2727 & 81082 \\
\hline 49 & 146062 & 11368 & 33922 & 2727 & 9982 \\
\hline 49 & 144091 & 11585 & 35081 & 2727 & 10882 \\
\hline 49 & 146125 & 12567 & 37524 & 2727 & 111182 \\
\hline 429 & 145871 & 4057 & 11079 & 1075 & 3282 \\
\hline 429 & 145921 & 4425 & 12600 & 1075 & 42182 \\
\hline 429 & 145933 & 4453 & 12970 & 1075 & 5382 \\
\hline 429 & 145963 & 4693 & 13870 & 1075 & 6282 \\
\hline 429 & 145993 & 5073 & 14880 & 1075 & 7282 \\
\hline 429 & 146027 & 5772 & 16131 & 1075 & 8582 \\
\hline 429 & 146055 & 6206 & 17129 & 1075 & 9282 \\
\hline 429 & 146084 & 6379 & 17907 & 1075 & 10182 \\
\hline 429 & 146116 & 5473 & 18727 & 1075 & 11282 \\
\hline 429 & 146148 & 6711 & 19751 & 1075 & 12482 \\
\hline 429 & 146208 & 7745 & 22296 & 1075 & 2283 \\
\hline 748 & 145692 & 495 & 1946 & 1515 & 9481 \\
\hline 748 & 145962 & 2795 & 6204 & 1515 & 6182 \\
\hline 748 & 145992 & 3519 & 7311 & 1515 & 7182 \\
\hline 748 & 145028 & 3909 & 8915 & 1515 & 8.682 \\
\hline 748 & 146054 & 4320 & 9943 & 1515 & 9182 \\
\hline 748 & 146088 & 4475 & 10992 & 1515 & 10582 \\
\hline 748 & 146116 & 4665 & 11875 & 1515 & 11282 \\
\hline 746 & 146178 & 5615 & 14865 & 1515 & 1383 \\
\hline 748 & 145971 & 9356 & 28778 & 1515 & 61082 \\
\hline 748 & 146007 & 9969 & 30495 & 1515 & 71682 \\
\hline 748 & 146032 & 10863 & 32281 & 1515 & 81082 \\
\hline 743 & 652 & 11368 & 33922 & 1515 & 9982 \\
\hline 748 & 146091 & 11585 & 35081 & 1515 & $10 \quad 882$ \\
\hline 748 & 25 & 12567 & 37524 & 1.51 .5 & 111182 \\
\hline 1075 & 146125 & 1334 & 4143 & 1583 & 111182 \\
\hline 1075 & 146155 & 2358 & 5196 & 1533 & 121182 \\
\hline 1075 & $14 b 186$ & 4361 & 9383 & 1583 & 11183 \\
\hline 1075 & 146220 & 7526 & 13744 & 1583 & 21483 \\
\hline 1075 & 146249 & 8748 & 16126 & 1583 & 31583 \\
\hline 1075 & 146306 & 9615 & 18449 & 1533 & 51183 \\
\hline 1.075 & 146336 & 10093 & 20042 & 1583 & 61083 \\
\hline 1075 & 14.4367 & 11191 & 22675 & 1583 & 71183 \\
\hline 1075 & 146396 & 12175 & 24570 & 1583 & 8983 \\
\hline 1075 & 146459 & 13222 & 27595 & 1583 & 101183 \\
\hline 1075 & 146492 & 13830 & 30145 & 1583 & 111383 \\
\hline 1075 & 146527 & 15738 & 32245 & $\begin{array}{l}1583 \\
1583\end{array}$ & 12188.3 \\
\hline 1075 & 146584 & 21846 & 40755 & 1583 & 21384 \\
\hline 1075 & 146613 & 23410 & 42826 & 1583 & 31384 \\
\hline 1075 & 146766 & 25605 & 49419 & 1583 & 81384 \\
\hline 1328 & 146233 & 3086 & 21769 & 2704 & 22783 \\
\hline 1328 & 146261 & 3810 & 23439 & 2704 & 32783 \\
\hline 1328 & 146296 & 4396 & 25177 & 2704 & 5183 \\
\hline 1328 & 146326 & 4514 & 26274 & 2704 & 53183 \\
\hline 1328 & 146352 & 5186 & 27536 & 2704 & 62683 \\
\hline
\end{tabular}




\begin{tabular}{|c|c|c|c|c|c|}
\hline $00 \#$ & J-DATE & $E M T$ & $M T F$ & IF T & IIATE \\
\hline $\begin{array}{l}1328 \\
1328 \\
1328\end{array}$ & $\begin{array}{l}146382 \\
146414 \\
146448\end{array}$ & $\begin{array}{l}6379 \\
3013 \\
8870\end{array}$ & $\begin{array}{l}29629 \\
32102 \\
33856\end{array}$ & $\begin{array}{l}2704 \\
2704 \\
2704\end{array}$ & $\begin{array}{l}7268 \\
8278 \\
9308\end{array}$ \\
\hline 1328 & 146480 & 9037 & 35117 & 2704 & 1118 \\
\hline 328 & 146510 & 9899 & 37047 & 2704 & 1218 \\
\hline 1328 & 146541 & 13338 & 40704 & 2704 & 118 \\
\hline 1328 & 146568 & 14378 & 44056 & 2704 & 1288 \\
\hline $\begin{array}{l}1328 \\
1328\end{array}$ & $\begin{array}{l}146559 \\
146689\end{array}$ & $\begin{array}{l}17232 \\
17585\end{array}$ & $\begin{array}{l}50402 \\
51658\end{array}$ & $\begin{array}{l}2704 \\
2704\end{array}$ & $\begin{array}{l}4288 \\
5288\end{array}$ \\
\hline 1100 & 145110 & 384 & 1486 & 2894 & 10278 \\
\hline 1100 & 146191 & 4658 & 7078 & 2894 & 1168 \\
\hline 1100 & 146223 & 5749 & 10139 & 2894 & 2178 \\
\hline 100 & 146260 & 7245 & 13565 & 2894 & 3268 \\
\hline 100 & $14628 ?$ & 7924 & 14740 & 2894 & 4178 \\
\hline 100 & 146327 & 8358 & 15385 & 2894 & 618 \\
\hline 100 & 146382 & 10237 & 18476 & 2894 & 7268 \\
\hline & 146438 & $1289 \mathrm{~s}$ & 22332 & 2894 & 9208 \\
\hline 00 & 146568 & 19122 & 32253 & 2894 & 1288 \\
\hline 25 & $1461>1$ & 1527 & 20503 & 1654 & 12278 \\
\hline 1125 & 146203 & 2792 & 23322 & 1654 & 1288 \\
\hline 125 & 146232 & 3714 & 25740 & 1654 & 2268 \\
\hline 1125 & 146265 & 4420 & 28250 & 1654 & 3318 \\
\hline 1125 & $14 t$ & 4860 & 31852 & 1654 & \\
\hline 1125 & 14 & 5891 & 34 & 16 & 710 \\
\hline 1125 & 146387 & 6642 & 36294 & 1654 & 7318 \\
\hline 1125 & 146418 & 7826 & 38804 & 1654 & 8318 \\
\hline 1125 & 146450 & 8405 & 41006 & 1654 & $102 \theta$ \\
\hline 1125 & 146432 & 8519 & 42828 & 1654 & 1138 \\
\hline 1125 & 15 & 9128 & 45331 & 1654 & 1268 \\
\hline 1125 & 146544 & 11766 & 48752 & 1.654 & 148 \\
\hline 1125 & 146579 & 12616 & 52663 & 1654 & 288 \\
\hline 1125 & $146 \leq 11$ & 13574 & 55635 & & 3118 \\
\hline 1308 & $14 t$ & 3284 & 4736 & 1583 & 1168 \\
\hline 1308 & $14 t$ & 5739 & 7952 & 1583 & 2158 \\
\hline 1308 & 146254 & 7428 & 10323 & 1583 & 32.08 \\
\hline 1308 & 146231 & 9420 & 12846 & 1583 & 416 \\
\hline 1308 & 146 & 10316 & 14559 & 1583 & 5268 \\
\hline $\begin{array}{l}1308 \\
1308\end{array}$ & $\begin{array}{l}14 \\
14\end{array}$ & $\begin{array}{l}10732 \\
11663\end{array}$ & $\begin{array}{l}15 \\
16\end{array}$ & $\begin{array}{l}1583 \\
1583\end{array}$ & 7168 \\
\hline 1308 & 146402 & 12932 & 18769 & 1583 & 8158 \\
\hline 1308 & 35 & 14184 & 21873 & 1583 & 917 \\
\hline 1308 & $14 t$ & 14356 & 22558 & 1583 & 10168 \\
\hline 1308 & 146 & 16706 & 25219 & 1583 & 12188 \\
\hline 1308 & 14 & 24862 & 36110 & 1583 & 416 \\
\hline 1308 & 146677 & 25433 & 37324 & 1583 & 5168 \\
\hline 1308 & 146 & 26132 & 38608 & 1583 & 616 \\
\hline 1308 & 146 & 27014 & 40275 & 1583 & \\
\hline 1308 & 146770 & 28844 & 42618 & 1583 & 8178 \\
\hline 1167 & 146115 & 437 & 84610 & 1340 & 1118 \\
\hline 1167 & 146145 & 1157 & 86160 & 1340 & 1218 \\
\hline 11 & 14 & 2101 & 87920 & 1340 & 118 \\
\hline & 14 & 3472 & 90120 & 1340 & 218 \\
\hline 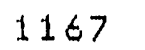 & 146235 & 4540 & 91900 & 1340 & 318 \\
\hline
\end{tabular}




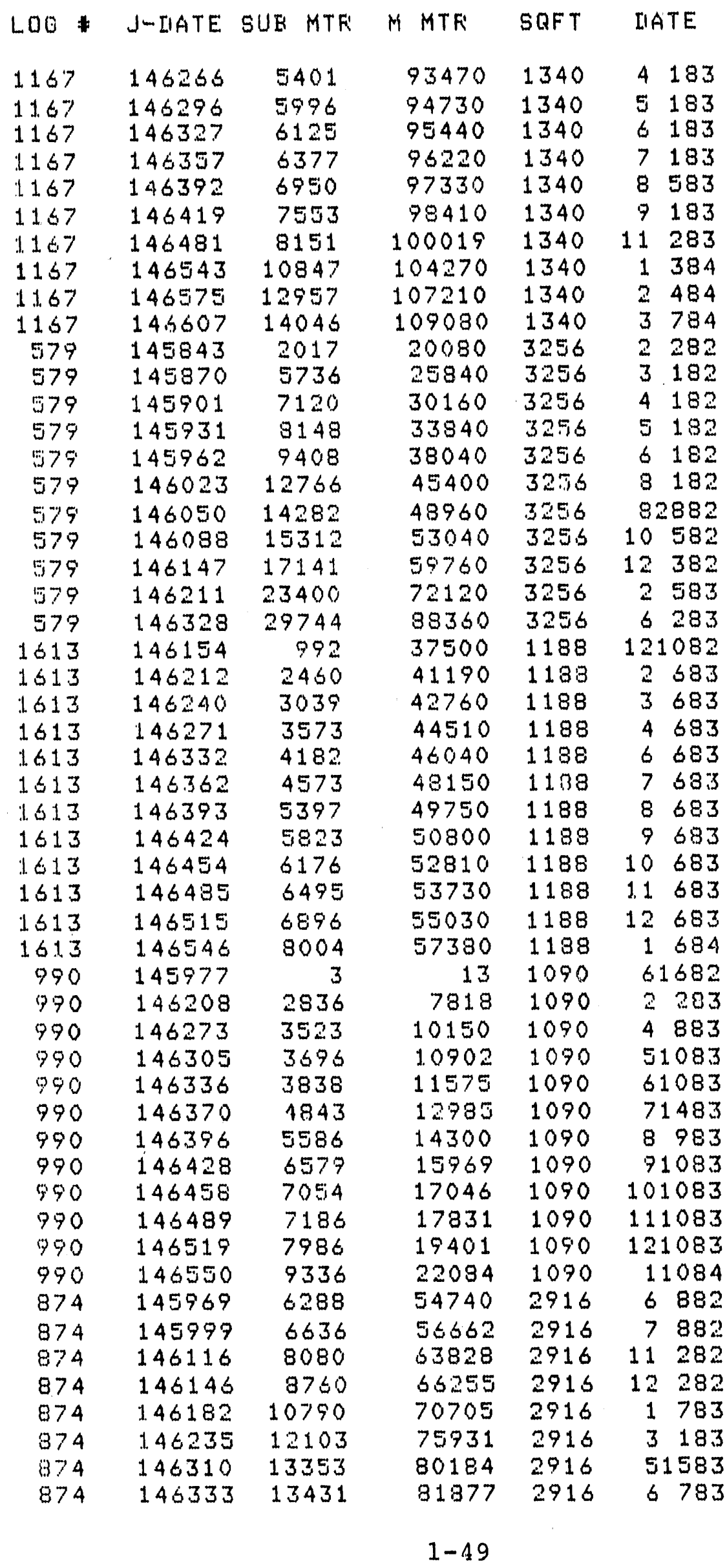




\begin{tabular}{|c|c|c|c|c|c|}
\hline $\log \neq$ & $J-$ LIATE & SUB MTR & M MTE & SQF T & IIATE \\
\hline 1070 & 146145 & 607 & 54090 & 1224 & 12182 \\
\hline 1070 & 146209 & 2163 & 56920 & 1224 & 2383 \\
\hline 1070 & 146235 & 2750 & 58070 & 1224 & 3183 \\
\hline 1070 & 146266 & 3189 & 59160 & 1224 & 4183 \\
\hline 1070 & 146296 & 3430 & 60010 & 1224 & 5183 \\
\hline 1070 & 146327 & 3545 & 60720 & 1224 & 6183 \\
\hline 1070 & 146357 & 3926 & 51720 & 1224 & 7183 \\
\hline 1070 & 146389 & 4553 & 62970 & 1224 & 8283 \\
\hline 1070 & 146420 & 5073 & 64040 & 1224 & 9283 \\
\hline 1070 & 146450 & 5334 & 64860 & 1224 & 10283 \\
\hline $\begin{array}{l}1070 \\
1070\end{array}$ & $\begin{array}{l}145481 \\
145510\end{array}$ & $\begin{array}{l}5494 \\
5801\end{array}$ & $\begin{array}{l}65580 \\
66390\end{array}$ & $\begin{array}{l}1224 \\
1224\end{array}$ & $\begin{array}{ll}11 & 283 \\
12 & 183\end{array}$ \\
\hline 1070 & 146342 & 7148 & 68330 & 1224 & 1284 \\
\hline 1079 & 146088 & 224 & 565 & 1842 & 10582 \\
\hline 1079 & 146130 & 2090 & 3845 & 1842 & 111682 \\
\hline 1079 & 146164 & 3652 & 6629 & 1842 & 122082 \\
\hline 1079 & 146190 & 5081 & 8756 & 1842 & 11583 \\
\hline 1079 & 146226 & 7932 & 12649 & 1842 & 22083 \\
\hline 1079 & 146232 & 10203 & 16338 & 1842 & 41783 \\
\hline 1079 & 146317 & 10811 & 17793 & 1842 & 52283 \\
\hline 1079 & 146343 & 11417 & 18844 & 1842 & 61783 \\
\hline 1079 & 146381 & 13058 & 21249 & 1842 & 72583 \\
\hline 1079 & 146405 & 14095 & 22696 & 1842 & 81883 \\
\hline 1079 & 146448 & 15476 & 24846 & 1842 & 93083 \\
\hline 1079 & $14647 ?$ & 15525 & 25502 & 1842 & 102483 \\
\hline $\begin{array}{l}1079 \\
1079\end{array}$ & & $\begin{array}{l}16103 \\
17574\end{array}$ & $\begin{array}{l}26667 \\
28868\end{array}$ & $\begin{array}{l}1842 \\
1842\end{array}$ & $\begin{array}{l}111683 \\
121583\end{array}$ \\
\hline 1079 & 146560 & 21405 & 33660 & 1842 & 12084 \\
\hline 1079 & 146594 & 25054 & 38356 & 1842 & 22384 \\
\hline 1079 & 146614 & 26241 & 40108 & 1842 & 31484 \\
\hline 1386 & 146132 & 694 & 2670 & 1490 & 111882 \\
\hline 1386 & 146162 & 1466 & 4570 & 1490 & 121882 \\
\hline 1386 & 146194 & 2406 & 6710 & 1490 & 11983 \\
\hline 1386 & 146225 & 3566 & 9010 & 1490 & 21983 \\
\hline 1386 & 146253 & 4068 & 10530 & 1490 & 31983 \\
\hline 1386 & 146285 & 4579 & 12211 & 1490 & 42083 \\
\hline 1386 & 146315 & 4813 & 13360 & 1490 & 52083 \\
\hline 1386 & 146346 & 5220 & 14770 & 1490 & 62083 \\
\hline 1336 & 146376 & 5905 & 16160 & 1490 & 72083 \\
\hline 1.386 & 146409 & 7083 & 18260 & 1490 & 82283 \\
\hline $\begin{array}{l}1386 \\
1386\end{array}$ & $\begin{array}{l}146440 \\
146477\end{array}$ & $\begin{array}{l}7788 \\
8102\end{array}$ & $\begin{array}{l}19900 \\
21090\end{array}$ & $\begin{array}{l}1490 \\
1490\end{array}$ & $\begin{array}{r}92283 \\
102983\end{array}$ \\
\hline 1386 & 145501 & 8346 & 22240 & 1490 & 112283 \\
\hline 1386 & 146538 & 10774 & 25910 & 1490 & 122983 \\
\hline 1386 & 146566 & 11360 & 27530 & 1490 & 12684 \\
\hline 1386 & 146680 & 13395 & 33470 & 1490 & 51984 \\
\hline 523 & 145689 & 1804 & 3305 & 2956 & $9 \quad 181$ \\
\hline 923 & 145824 & 5848 & 15812 & 2956 & 11482 \\
\hline 523 & 145902 & 8530 & 23493 & 2956 & 4282 \\
\hline 523 & 145940 & 8967 & 25966 & 2956 & 51082 \\
\hline 523 & 146007 & 11179 & 31089 & 2956 & 71682 \\
\hline 523 & 146037 & 12605 & 33653 & 2956 & 81582 \\
\hline 523 & 146079 & 13731 & 36548 & 2956 & 92682 \\
\hline
\end{tabular}




\begin{tabular}{|c|c|c|c|c|c|}
\hline $.0 G \neq$ & $J$ JIIATE & SUB MTK & $M M T F$ & SQFT & IIATE \\
\hline $\begin{array}{l}523 \\
523 \\
523 \\
456\end{array}$ & $\begin{array}{l}146145 \\
146184 \\
146219 \\
146297\end{array}$ & $\begin{array}{r}15294 \\
17979 \\
21242 \\
4922\end{array}$ & $\begin{array}{r}41654 \\
46812 \\
52470 \\
6399\end{array}$ & $\begin{array}{l}2956 \\
2956 \\
2956 \\
1842\end{array}$ & $\begin{array}{rr}12 & 182 \\
1 & 983 \\
21383 \\
5 \quad 283\end{array}$ \\
\hline $\begin{array}{l}1456 \\
1456\end{array}$ & $\begin{array}{l}146327 \\
146358\end{array}$ & $\begin{array}{l}5192 \\
5768\end{array}$ & $\begin{array}{l}7436 \\
8901\end{array}$ & $\begin{array}{l}1842 \\
1842\end{array}$ & $\begin{array}{ll}6 & 18 \\
7 & 28\end{array}$ \\
\hline 1456 & 144390 & 7036 & 10954 & 1842 & $\begin{array}{ll}8 & 38 \\
0 & 38\end{array}$ \\
\hline 14 & 146421 & 8322 & 13058 & 1842 & 938 \\
\hline 1456 & 146451 & 8914 & 14443 & 1842 & 1038 \\
\hline 145 & 14,5483 & 9242 & 15695 & 1842 & 1148 \\
\hline 1456 & 146012 & 10257 & 17467 & 1842 & 1238 \\
\hline 0 & 146574 & 15156 & 23852 & 1842 & 238 \\
\hline 1456 & 14.5634 & 17438 & 27661 & 1842 & 438 \\
\hline 396 & 14.6210 & 97169 & 6121 & 1134 & 248 \\
\hline 39 & 14.5 & 96408 & & 11 & 3 \\
\hline 396 & 146271 & 95774 & 9861 & 1134 & 468 \\
\hline 396 & 145309 & 95598 & 11514 & 1134 & 5148 \\
\hline 396 & 146335 & 95429 & 12466 & 1134 & 698 \\
\hline 396 & 14 & 94344 & 15046 & 1134 & 7298 \\
\hline $\begin{array}{l}396 \\
396\end{array}$ & & $\begin{array}{l}93373 \\
93129\end{array}$ & & $\begin{array}{l}1134 \\
1134\end{array}$ & $\begin{array}{l}9108 \\
1078\end{array}$ \\
\hline 396 & 00 & 72525 & 21561 & 1134 & 11218 \\
\hline 396 & 24 & 91804 & 22269 & 1134 & 12158 \\
\hline 2973 & 146600 & 1070 & 1116 & 1842 & 2298 \\
\hline 2973 & 146 & 2284 & 3380 & 1842 & 418 \\
\hline 2973 & 14 & 2533 & 4810 & 1842 & 518 \\
\hline 2973 & 14 & 3132 & 6703 & 1842 & 678 \\
\hline 2973 & 14 & 4487 & 9939 & 1842 & 738 \\
\hline 2973 & 14 & 572.5 & 12500 & 1842 & 838 \\
\hline 2973 & 146 & 7694 & 15532 & 1842 & 1098 \\
\hline 2973 & 146347 & 8231 & 17130 & 1842 & 1148 \\
\hline 2973 & 146883 & 10753 & 20073 & 1842 & 128 \\
\hline 2973 & 145 & 11655 & 22232 & 1342 & 1 \\
\hline 2973 & 14 & 13695 & 26561 & 1842 & 288 \\
\hline 2973 & 14. & 14974 & 28886 & 1842 & \\
\hline 1453 & 14 & 16934 & 28119 & 1839 & 12 \\
\hline 1453 & 146 & 19620 & 32610 & 1839 & 4 \\
\hline 1453 & 146 & 20120 & 33677 & 1839 & 425 \\
\hline 1453 & $14 t$ & 20477 & 34818 & 1839 & 531 \\
\hline 53 & 20 & 21554 & 36583 & 1839 & 628 \\
\hline & 1.4 & 2337 & & 1839 & \\
\hline 1453 & 146 & 24680 & 42027 & 1839 & 1016 \\
\hline 1453 & 14 & 26566 & 48 & 1839 & 1226 \\
\hline & 14 & 31789 & 52063 & 1839 & 3 \\
\hline & 14 & 11905 & 17112 & 1773 & 21 \\
\hline 2837 & 146616 & 12564 & 19694 & 1773 & 316 \\
\hline 2837 & 14 & 13344 & 21489 & 1773 & 417 \\
\hline 2837 & 146683 & 13588 & 22822 & 1773 & 522 \\
\hline 2837 & 14 & 14581 & 24605 & 1773 & 517 \\
\hline 2837 & 146737 & $\begin{array}{l}15848 \\
172\end{array}$ & $\begin{array}{l}26918 \\
20=70\end{array}$ & $\begin{array}{l}1773 \\
1773\end{array}$ & 71 \\
\hline & & & & 1773 & \\
\hline 837 & $\begin{array}{l}140 / 79 \\
146899\end{array}$ & 18401 & $\begin{array}{l}31240 \\
32467\end{array}$ & 1773 & 1 \\
\hline & & & & & \\
\hline
\end{tabular}




\begin{tabular}{|c|c|c|c|c|c|}
\hline LOG & $J$-IIATE & SUE MTF & M MTK & SRFT & IIATE \\
\hline $\begin{array}{l}2837 \\
2837\end{array}$ & $\begin{array}{l}146860 \\
146890\end{array}$ & $\begin{array}{l}18813 \\
20170\end{array}$ & $\begin{array}{l}33829 \\
36184\end{array}$ & $\begin{array}{l}1773 \\
1773\end{array}$ & $\begin{array}{l}111584 \\
121584\end{array}$ \\
\hline 2837 & 146923 & 21932 & 39298 & 1773 & 11785 \\
\hline $\begin{array}{l}2837 \\
2837\end{array}$ & $\begin{array}{l}146952 \\
146979\end{array}$ & $\begin{array}{l}25344 \\
26117\end{array}$ & $\begin{array}{l}43577 \\
45221\end{array}$ & $\begin{array}{l}1773 \\
1773\end{array}$ & $\begin{array}{l}21585 \\
31485\end{array}$ \\
\hline 2255 & 146552 & 6956 & 9489 & 2168 & 11284 \\
\hline 2255 & 146585 & 8527 & 13314 & 2168 & 21484 \\
\hline 2255 & 146611 & 9527 & 15196 & 2168 & 31184 \\
\hline 2255 & 146640 & 9828 & 16413 & 2168 & 4984 \\
\hline 2255 & 146675 & 10012 & 17660 & 2168 & 51484 \\
\hline 2255 & 146765 & 13125 & 22585 & 2168 & 81284 \\
\hline 2255 & 146797 & 14244 & 24141 & 2168 & 91384 \\
\hline 2255 & 146825 & 14718 & 25071 & 2168 & 101184 \\
\hline 2255 & 146857 & 15270 & 26302 & 2168 & 111284 \\
\hline 2255 & 146886 & 17044 & 28740 & 2168 & 121184 \\
\hline 2255 & 146923 & 19005 & 31394 & 2168 & 11785 \\
\hline 2255 & 146976 & 25624 & 39198 & 2168 & 31185 \\
\hline 2434 & 146576 & 6833 & 10146 & 1839 & 2584 \\
\hline 2434 & 146639 & 9283 & 15037 & 1839 & 4884 \\
\hline 2434 & 146671 & 7635 & 16362 & 1339 & 51084 \\
\hline 2434 & 146702 & 10071 & 17834 & 1839 & 61084 \\
\hline 2434 & 146730 & 10847 & 19656 & 1839 & 7884 \\
\hline 2434 & 146763 & 11736 & 21605 & 1839 & 81084 \\
\hline 2434 & 146793 & 12568 & 23565 & 1839 & 9784 \\
\hline 2434 & 146826 & 13115 & 25271 & 1839 & 101284 \\
\hline 2434 & 146856 & 13750 & 26795 & 1839 & 111184 \\
\hline 2434 & 146884 & 15323 & 29282 & 1839 & 12984 \\
\hline 2434 & 146919 & 17064 & 32284 & 1839 & 11385 \\
\hline 2434 & 146947 & 21090 & 37312 & 1839 & 21085 \\
\hline 2434 & 146974 & 22816 & 40085 & 1339 & 3985 \\
\hline 1767 & 146515 & 600 & 3050 & 2254 & 12683 \\
\hline 1767 & 146542 & 2429 & 7029 & 2254 & 1284 \\
\hline 1767 & 146580 & 5558 & 12420 & 2254 & 2984 \\
\hline 1767 & 146609 & 6657 & 15093 & 2254 & 3934 \\
\hline 1767 & 146641 & 7300 & 17299 & 2254 & 41084 \\
\hline 1767 & 146671 & 7438 & 18650 & 2254 & 51084 \\
\hline 1767 & 146704 & 7775 & 20188 & 2254 & 61284 \\
\hline 1767 & 140732 & 8344 & 22041 & 2254 & 71084 \\
\hline 1767 & 146763 & 8850 & 23560 & 2254 & 81084 \\
\hline 1767 & 146795 & 9357 & 25120 & 2254 & 91184 \\
\hline 1767 & 146829 & 9461 & 26562 & 2254 & 101584 \\
\hline 1767 & 146862 & 10971 & 28474 & 2254 & 111784 \\
\hline 1767 & 146888 & 11020 & 30601 & 2254 & 121384 \\
\hline 1767 & 146925 & 12145 & 34692 & 2254 & 11985 \\
\hline 1767 & 146956 & 15914 & 39009 & 2254 & 21985 \\
\hline 2670 & 146474 & 886 & 2108 & 1423 & 102683 \\
\hline 2690 & 146542 & 2383 & 4994 & 1423 & 1284 \\
\hline 2690 & 146572 & 3362 & 6552 & 1423 & 2184 \\
\hline 2690 & 146603 & 3916 & 7903 & 1423 & 3384 \\
\hline 2690 & 146631 & 4258 & 8804 & 1423 & 33184 \\
\hline 2090 & 146676 & 4493 & 10155 & 1423 & 51584 \\
\hline 2690 & 146696 & 4680 & 10804 & 1423 & $6 \quad 484$ \\
\hline $3 \leq 90$ & 146753 & $\leq 217$ & 13800 & 1423 & 73184 \\
\hline
\end{tabular}




\begin{tabular}{|c|c|c|c|c|c|}
\hline$-O Q \neq$ & $J-$ IIATE & JE MTE & $M$ MTE & SQF T & LIATE \\
\hline $\begin{array}{l}2690 \\
2690 \\
6690\end{array}$ & $\begin{array}{l}146787 \\
146814 \\
146845\end{array}$ & $\begin{array}{l}6944 \\
7224 \\
7323\end{array}$ & $\begin{array}{l}15400 \\
16229 \\
16900\end{array}$ & $\begin{array}{l}1423 \\
1423 \\
1423\end{array}$ & $\begin{array}{r}9384 \\
73084 \\
103184\end{array}$ \\
\hline & 146876 & 7521 & 17854 & 1423 & 12184 \\
\hline & 146908 & 8091 & 18843 & 1423 & 128 \\
\hline & 146967 & 10446 & 22.372 & 1423 & 328 \\
\hline & 146328 & 558 & 978 & 1423 & 6283 \\
\hline & 146357 & $\begin{array}{r}624 \\
1025\end{array}$ & $\begin{array}{l}1527 \\
2517\end{array}$ & $\begin{array}{l}1423 \\
1423\end{array}$ & $\begin{array}{ll}7 & 183 \\
8 & 383\end{array}$ \\
\hline 2079 & 119 & $\begin{array}{l}1025 \\
1475\end{array}$ & 3478 & 1423 & $\begin{array}{ll}8 & 38 \\
9 & 18\end{array}$ \\
\hline 93 & 146449 & 1685 & 4293 & 1423 & 1018 \\
\hline & 146476 & 1741 & 4701 & 1423 & 10288 \\
\hline 93 & 146510 & 2199 & 5583 & 1423 & 1218 \\
\hline & 146541 & 3367 & 7384 & 1423 & 118 \\
\hline & 146572 & 4579 & 9143 & 1423 & 218 \\
\hline 93 & 146601 & 5060 & 10310 & 142.3 & 318 \\
\hline 93 & & 5560 & 11360 & 1423 & 418 \\
\hline 93 & 14 & 5705 & 12071 & 1423 & 518 \\
\hline 93 & 146693 & 5744 & 12670 & 1423 & 618 \\
\hline 2093 & 146754 & 6624 & 14534 & 1423 & 818 \\
\hline 2093 & 146786 & 7328 & 15830 & 1423 & 928 \\
\hline 2093 & 146815 & 7520 & 16604 & 1423 & 1018 \\
\hline $\begin{array}{l}2093 \\
2093\end{array}$ & $\begin{array}{l}146 \\
14\end{array}$ & $\begin{array}{l}7733 \\
8300\end{array}$ & $\begin{array}{l}17304 \\
13391\end{array}$ & $\begin{array}{l}1423 \\
1423\end{array}$ & $\begin{array}{ll}11 & 18 \\
12 & 18\end{array}$ \\
\hline 2093 & 146907 & 8747 & 19399 & 1423 & 118 \\
\hline 2093 & 146956 & 10913 & 22663 & 1423 & 318 \\
\hline 3203 & 48 & 17 & 359 & 1102 & 4178 \\
\hline 3203 & 14 & 63 & 543 & 1102 & 4278 \\
\hline .03 & 14 & 501 & 1536 & 1102 & 638 \\
\hline 203 & 14 & 1113 & 2641 & 1102 & 718 \\
\hline 03 & 14 & 1745 & 3688 & 1102 & 7308 \\
\hline 03 & 14 & 2496 & 4969 & 1102 & 93 \\
\hline 203 & 146814 & 2858 & 5773 & 1102 & 9308 \\
\hline 3203 & 146849 & 3205 & 5618 & 1102 & 1148 \\
\hline 3203 & 146877 & 3211 & 7052 & 1102 & 1228 \\
\hline 3203 & 146 & 3322 & 3103 & 1102 & 1308 \\
\hline 3203 & 14 & 3357 & 8661 & 1102 & 338 \\
\hline $\begin{array}{l}1753 \\
1753\end{array}$ & $\begin{array}{l}14 \\
14\end{array}$ & $\begin{array}{l}4851 \\
6312\end{array}$ & $\begin{array}{r}9434 \\
12024\end{array}$ & $\begin{array}{l}1161 \\
1161\end{array}$ & $\begin{array}{l}1268 \\
3198\end{array}$ \\
\hline 1753 & 14 & 6710 & 13046 & 1161 & 4178 \\
\hline & & 6802 & 135 & 1161 & \\
\hline 1753 & 14 & 7083 & 14384 & 1161 & 6168 \\
\hline 753 & 1.4 & 7443 & 151 & 1161 & 7148 \\
\hline 1753 & 14 & 7860 & 16 & 1161 & 8178 \\
\hline 1753 & 146805 & 8240 & 17080 & 1161 & 9218 \\
\hline 1753 & 146837 & 8443 & 17798 & 1161 & 10238 \\
\hline 1753 & 146 & 8936 & 18880 & 1161 & 11228 \\
\hline 1753 & 145701 & 9795 & 20405 & 1161 & 12268 \\
\hline 1753 & 146966 & 12426 & 24589 & 1161 & 318 \\
\hline 3112 & 146 & 2240 & 14150 & 1102 & 3288 \\
\hline 3112 & 14 & 3058 & 15740 & 1102 & 628 \\
\hline 3112 & & 3488 & 15450 & 1102 & 628 \\
\hline उIIZ & 140754 & jóóó & 17270 & İ०2 & 61 \\
\hline
\end{tabular}




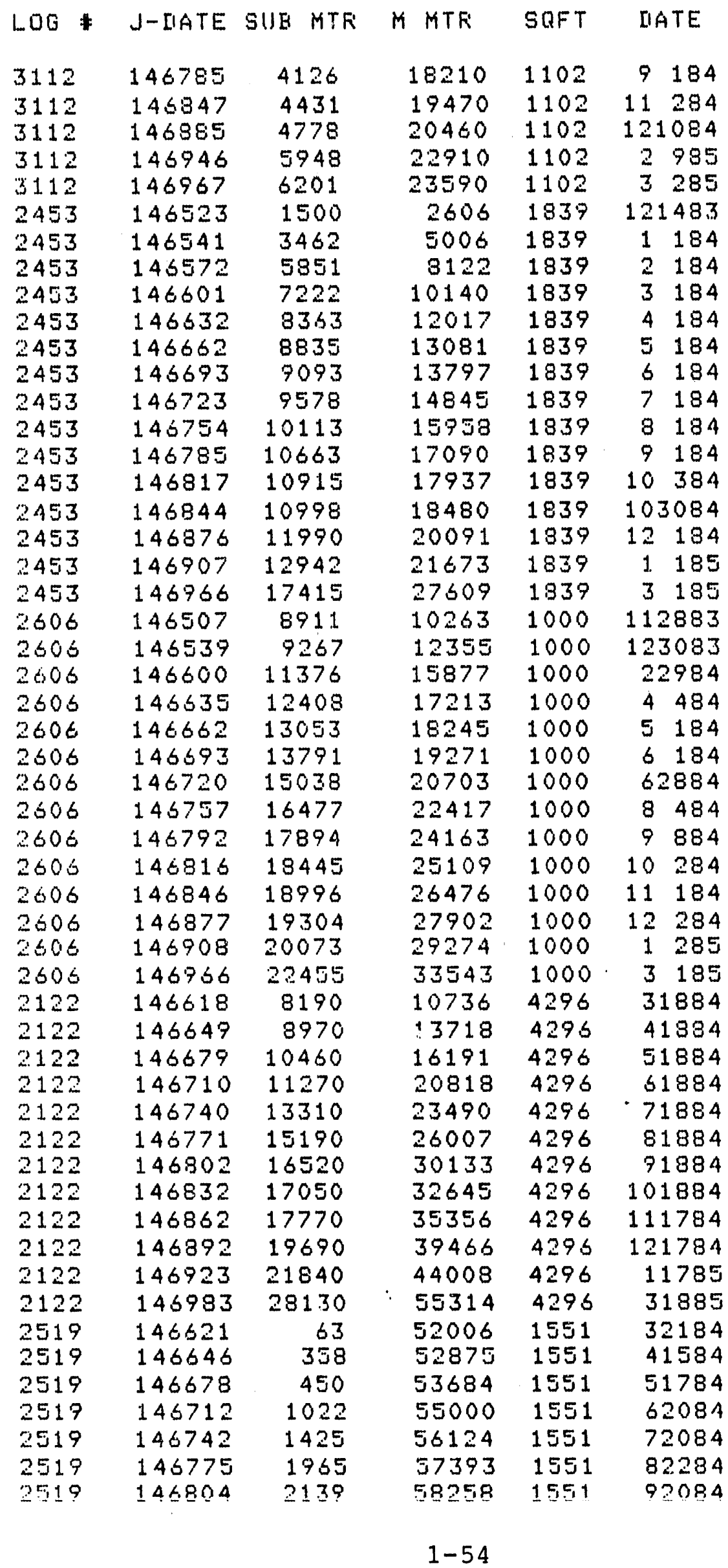


LOG * J-LIATE SUE MTF M MTF SQFT IIATE

$\begin{array}{llllll}2519 & 146831 & 2250 & 58978 & 1551 & 101784\end{array}$

$2519 \quad 146861 \quad 2560 \quad 60070 \quad 1551 \quad 111684$

$\begin{array}{llllll}2519 & 146890 & 2943 & 61444 & 1551 & 121584\end{array}$

$\begin{array}{llllll}2519 & 146922 & 4401 & 63808 & 1551 & 11685\end{array}$ 
APPENDIX 2

POSTCARD FOR METER DATA READING 

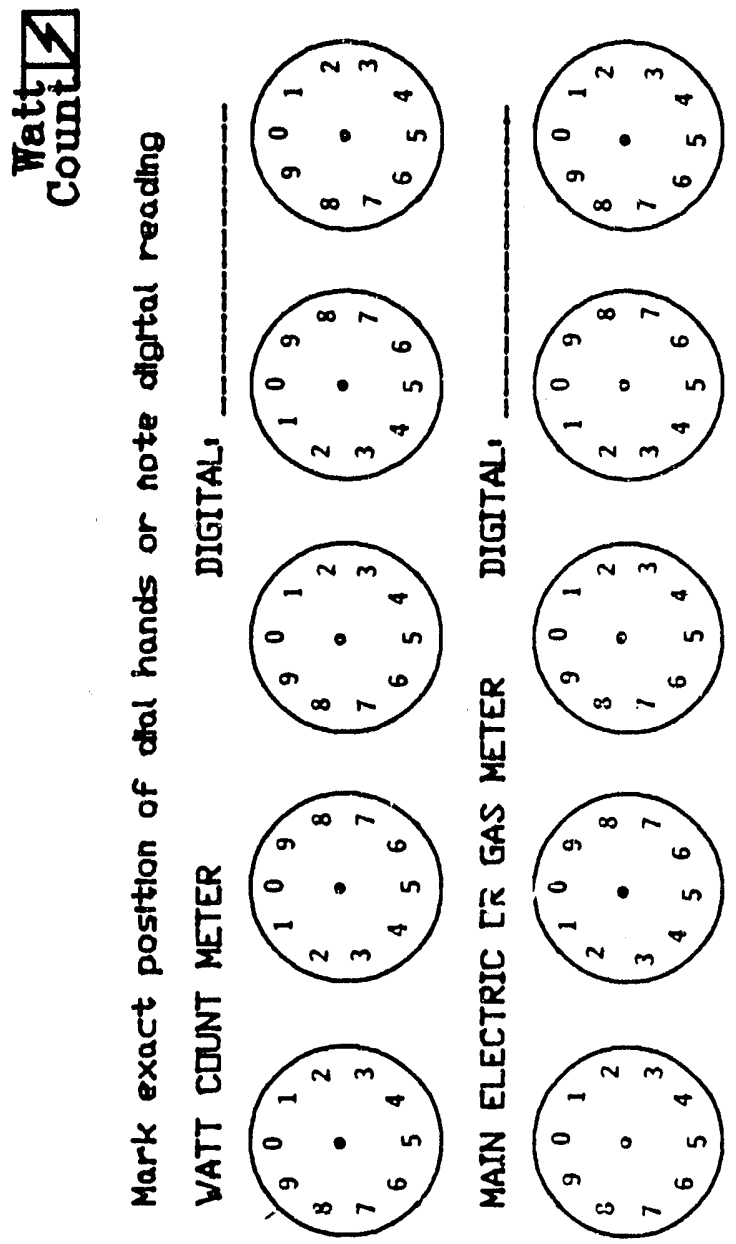


\section{APPENDIX 3}

NATIUNAL WEATHER BUREAU HEATING

DEGREE-DAY DATA FOR MIDDLE TENNESSEE 
$--78 / 79---79 / 80---80 / 81-\cdots 81 / 82-\cdots 82 / 83-\cdots \cdots 83 / 84-\cdots 84 / 85 \cdots \cdots 85 / 86$

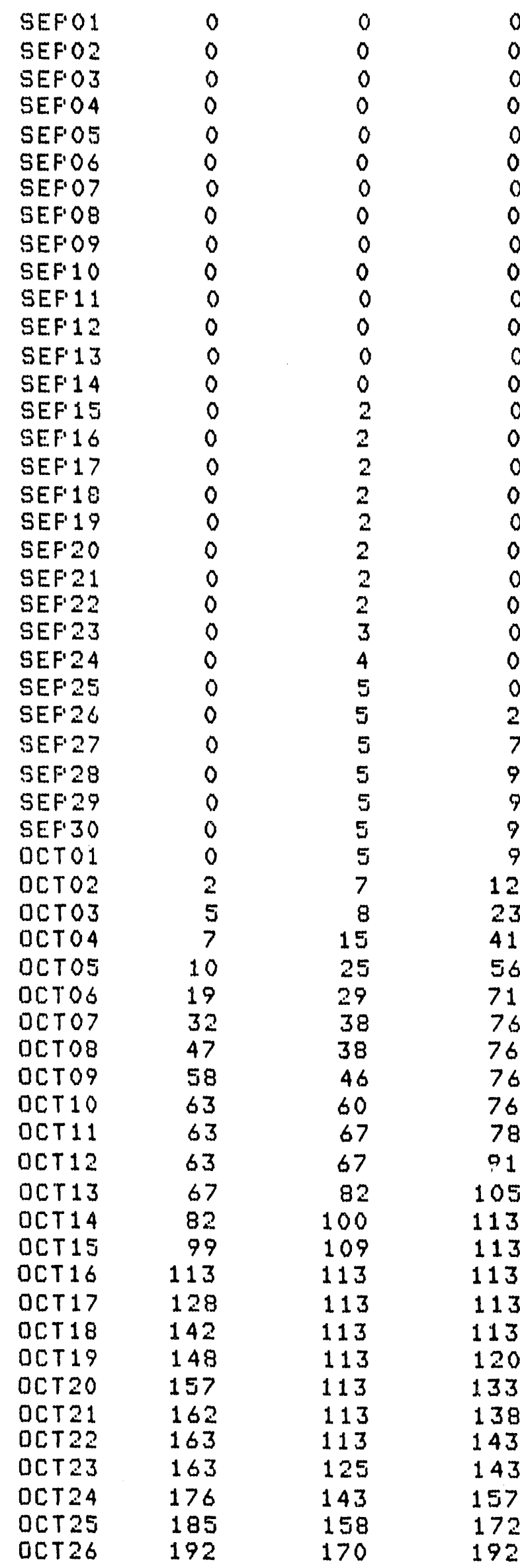

\begin{tabular}{|c|c|}
\hline 0 & 0 \\
\hline 0 & 0 \\
\hline 0 & 0 \\
\hline 0 & 0 \\
\hline 0 & 0 \\
\hline 0 & 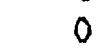 \\
\hline 0 & 0 \\
\hline 0 & 0 \\
\hline 0 & 0 \\
\hline 0 & 0 \\
\hline 0 & 0 \\
\hline 0 & 0 \\
\hline 0 & 0 \\
\hline 0 & 0 \\
\hline 0 & 0 \\
\hline 0 & 0 \\
\hline 6 & \\
\hline 16 & . \\
\hline 26 & \\
\hline $\begin{array}{l}30 \\
32\end{array}$ & 0 \\
\hline $\begin{array}{l}32 \\
32\end{array}$ & 15 \\
\hline 35 & 22 \\
\hline 38 & 25 \\
\hline 38 & 26 \\
\hline 38 & 28 \\
\hline 38 & 30 \\
\hline 40 & 30 \\
\hline 42 & 30 \\
\hline 42 & 30 \\
\hline 42 & 30 \\
\hline 53 & 30 \\
\hline 63 & 30 \\
\hline 66 & 30 \\
\hline 66 & 30 \\
\hline 66 & 30 \\
\hline 71 & 30 \\
\hline 77 & 30 \\
\hline 82 & 30 \\
\hline 82 & 30 \\
\hline 82 & 32 \\
\hline 83 & 42 \\
\hline 83 & 44 \\
\hline 84 & 53 \\
\hline 84 & 58 \\
\hline 84 & 68 \\
\hline 84 & 81 \\
\hline 88 & 86 \\
\hline 103 & 88 \\
\hline 115 & 98 \\
\hline 118 & 114 \\
\hline 124 & 132 \\
\hline 143 & 149 \\
\hline 166 & 165 \\
\hline $\begin{array}{l}179 \\
183\end{array}$ & $\begin{array}{l}180 \\
197\end{array}$ \\
\hline
\end{tabular}

\begin{tabular}{|c|c|c|}
\hline 0 & 0 & 0 \\
\hline 0 & 0 & 0 \\
\hline 0 & 0 & 0 \\
\hline 0 & 0 & 0 \\
\hline 0 & 1 & 0 \\
\hline 0 & 1 & 0 \\
\hline 0 & 1 & 0 \\
\hline 0 & 1 & 0 \\
\hline 0 & 1 & 0 \\
\hline 0 & 1 & 0 \\
\hline 0 & 1 & 0 \\
\hline 0 & 1 & 0 \\
\hline 0 & 1 & 1 \\
\hline 0 & 1 & 5 \\
\hline 0 & 3 & 6 \\
\hline 0 & 9 & 6 \\
\hline 0 & 12 & 6 \\
\hline 0 & 12 & 6 \\
\hline 0 & 12 & 6 \\
\hline 0 & 12 & 6 \\
\hline 11 & 12 & 6 \\
\hline 23 & 12 & 6 \\
\hline 31 & 1.2 & 6 \\
\hline 41 & 12 & 10 \\
\hline 45 & 12 & 11 \\
\hline 45 & 18 & 15 \\
\hline 45 & 28 & 23 \\
\hline 45 & 40 & 29 \\
\hline 45 & 49 & 30 \\
\hline 45 & 59 & 30 \\
\hline 45 & 71 & 47 \\
\hline 45 & 85 & 61 \\
\hline 45 & 93 & 67 \\
\hline 45 & 94 & 69 \\
\hline 45 & 94 & 81 \\
\hline 46 & 95 & 93 \\
\hline 46 & 95 & 102 \\
\hline 46 & 95 & 103 \\
\hline 46 & 95 & 103 \\
\hline 46 & 95 & 103 \\
\hline 46 & 95 & 103 \\
\hline 48 & 95 & 103 \\
\hline 62 & 95 & 103 \\
\hline 73 & 95 & 103 \\
\hline 81 & 95 & 103 \\
\hline 82 & 95 & 105 \\
\hline 82 & 95 & 107 \\
\hline 82 & 95 & 107 \\
\hline 82 & 95 & 107 \\
\hline 82 & 95 & 107 \\
\hline 82 & 95 & 107 \\
\hline 85 & 100 & 109 \\
\hline 94 & 111 & $10 \%$ \\
\hline 03 & 120 & 109 \\
\hline 17 & 120 & 111 \\
\hline 29 & 120 & 112 \\
\hline
\end{tabular}


$\cdots-78 / 79---79 / 80---80 / 81--81 / 82-m 82 / 83-\cdots-83 / 84--\cdots 84 / 85-\cdots 85 / 86 \%$

\begin{tabular}{|c|c|c|c|c|c|c|c|c|}
\hline $\begin{array}{l}\text { OCT2 } \\
\text { OCT28 }\end{array}$ & $\begin{array}{l}207 \\
220\end{array}$ & $\begin{array}{l}176 \\
179\end{array}$ & $\begin{array}{l}204 \\
210\end{array}$ & $\begin{array}{l}196 \\
206\end{array}$ & $\begin{array}{l}210 \\
217\end{array}$ & $\begin{array}{l}142 \\
150\end{array}$ & $\begin{array}{l}120 \\
120\end{array}$ & $\begin{array}{l}112 \\
112\end{array}$ \\
\hline OCT29 & 230 & 183 & 231 & 212 & 224 & 155 & 120 & 113 \\
\hline OCT30 & 237 & 185 & 251 & 215 & 224 & 161 & 122 & 121 \\
\hline OCT 31 & 241 & 185 & 268 & 217 & 224 & 166 & 122 & 121 \\
\hline NOUOI & 245 & 193 & 278 & 219 & 224 & 170 & 122 & 127 \\
\hline NOUOZ & 249 & 206 & 287 & 220 & 224 & 170 & 140 & 139 \\
\hline NOUOZ & 255 & 224 & 294 & 223 & 234 & 171 & 153 & 155 \\
\hline NOUOA & 264 & 242 & 305 & 224 & 259 & 186 & 160 & 172 \\
\hline NOVOS & 271 & 257 & 322 & 229 & 288 & 207 & 167 & 187 \\
\hline NOVOG & 277 & 270 & 339 & 242 & 314 & 225 & 187 & 201 \\
\hline NOVOT & 290 & 290 & 339 & 259 & 331 & 240 & 208 & 223 \\
\hline NOUOE & 307 & 307 & 339 & 272 & 341 & 252 & 224 & 241 \\
\hline NOVOQ & 324 & 317 & 343 & 281 & 351 & 258 & 227 & 247 \\
\hline NOU 10 & 334 & 339 & 352 & 301 & 360 & 271 & 237 & 247 \\
\hline NOU11 & 341 & 363 & 368 & 316 & 363 & 296 & 261 & 249 \\
\hline NOU12 & 343 & 387 & 382 & 333 & 375 & 324 & 289 & 248 \\
\hline NOU 13 & 343 & 407 & 393 & 351 & 406 & 347 & 317 & 248 \\
\hline NOU1 4 & 343 & 432 & 404 & 367 & 432 & 369 & 335 & 248 \\
\hline NOU15 & 345 & 453 & 416 & 382 & 4.61 & 386 & 346 & 248 \\
\hline NOV 16 & 351 & 467 & 435 & 397 & 485 & 409 & 369 & 254 \\
\hline Nov 17 & 357 & 479 & 457 & 412 & 500 & 430 & 396 & 267 \\
\hline NOU 18 & 372 & 492 & 482 & 428 & 510 & 440 & 417 & 267 \\
\hline NOU19 & 393 & 500 & 509 & 434 & 513 & 440 & 442 & 267 \\
\hline NOUבO & 408 & 500 & 535 & 461 & 514 & 454 & 474 & 279 \\
\hline NOU21 & 423 & 501 & 558 & 493 & 515 & 468 & 505 & 302 \\
\hline NOU2 & 439 & 505 & 583 & 523 & 516 & 474 & 534 & 319 \\
\hline NOUZZ & 447 & 522 & 598 & 545 & 523 & 477 & 562 & 336 \\
\hline NOV24 & 464 & 541 & 616 & 566 & 550 & 501 & 585 & 347 \\
\hline NOU2S & 488 & 550 & 639 & 582 & 576 & 521 & 601 & 352 \\
\hline NOU2S & 502 & 565 & 664 & 587 & 595 & 535 & 607 & 352 \\
\hline NOU27 & 513 & 577 & 687 & 502 & $\$ 10$ & 544 & 615 & 352 \\
\hline NQU28 & 537 & 601 & 715 & 623 & 618 & 563 & 641 & 362 \\
\hline NOU27 & 560 & 636 & 737 & 645 & 630 & 587 & 665 & 376 \\
\hline NOU 30 & 579 & 672 & 755 & 662 & 637 & 613 & 684 & 385 \\
\hline IIECO 1 & 601 & 699 & 765 & 575 & 637 & 636 & 706 & 401 \\
\hline [IECO2 & 612 & 737 & 784 & 694 & 637 & 661 & 725 & 439 \\
\hline [IECOZ & 615 & 771. & 813 & 714 & 637 & 671 & 750 & 476 \\
\hline IIECO4 & 634 & 795 & 834 & 734 & 637 & 684 & 785 & 503 \\
\hline [IECOS & 660 & 814 & 847 & 760 & 645 & 694 & 316 & 523 \\
\hline IIECO6 & 676 & 837 & 856 & 783 & 667 & 711 & 858 & 555 \\
\hline IIECO7 & 682 & 858 & 864 & 792 & 687 & 741 & 899 & 585 \\
\hline IIECOB & 697 & 886 & 868 & 813 & 704 & 764 & 923 & 604 \\
\hline IIECOQ & 735 & 911 & 880 & 844 & 729 & 784 & 941 & 620 \\
\hline DEC 10 & 773 & 928 & 905 & 875 & 757 & 795 & 954 & 630 \\
\hline IIEC 11 & 806 & 937 & 928 & 908 & 784 & 801 & 969 & 642 \\
\hline IIEC 12 & 833 & 949 & 946 & 938 & 821 & 819 & 980 & 606 \\
\hline $\operatorname{IIEC} 13$ & 855 & 976 & 964 & 968 & 856 & 841 & 780 & 702 \\
\hline IIEC 14 & 887 & 1005 & 992 & 992 & 877 & 864 & 980 & 748 \\
\hline IIEC 15 & 912 & 1027 & 1016 & 1021 & 896 & 891 & 984 & 785 \\
\hline [IEC 16 & 932 & 1051 & 1043 & 1052 & 926 & 923 & 986 & 813 \\
\hline$[\because E C 17$ & 960 & 1091 & 1073 & 1079 & 754 & 956 & 986 & 839 \\
\hline IIEC 18 & 987 & 1126 & 1091 & 1123 & 978 & 988 & 994 & 883 \\
\hline [IEC 19 & 997 & 1149 & 1120 & 1170 & 998 & 1033 & 1001 & 929 \\
\hline IIEC 20 & 1004 & 1168 & 1164 & 1215 & 1019 & 1073 & 1018 & 970 \\
\hline [IEC 21 & 1032 & 1185 & 1204 & 1245 & 1045 & 1098 & 1023 & 101 \\
\hline पIEC22 & 1058 & 1198 & 1240 & 1258 & 1064 & 1131 & 1045 & 104 \\
\hline \multirow[t]{2}{*}{ [IEC 23} & 1081 & 1208 & 1261 & 1278 & 1071 & 1180 & 1068 & 106 \\
\hline & & & & $3-2$ & & & & \\
\hline
\end{tabular}




\begin{tabular}{|c|c|c|c|c|c|c|c|c|}
\hline & $--78 / 79$ & $---79 / 80$ & $---80 / 81$ & $-\cdots \cdot 81 / 82$ & $--.02 / 83$ & $-\cdots 03 / 84 \cdots$ & $\cdots 64 / 85$ & $--\cdots 85 / 86-$ \\
\hline [IEC 24 & 1104 & 1224 & 1288 & 1310 & 1071 & 1.242 & 1085 & 1095 \\
\hline $\begin{array}{l}\text { IIEC25 } \\
\text { IIEC } 26 \\
\text { IIEC } 27\end{array}$ & $\begin{array}{l}1131 \\
1159 \\
1193\end{array}$ & $\begin{array}{l}1250 \\
1279 \\
1309\end{array}$ & $\begin{array}{l}1332 \\
1365 \\
1395\end{array}$ & $\begin{array}{l}1336 \\
1358 \\
1378\end{array}$ & $\begin{array}{l}1071 \\
1076 \\
1076\end{array}$ & $\begin{array}{l}1302 \\
1354 \\
1390\end{array}$ & $\begin{array}{l}1117 \\
1139 \\
1148\end{array}$ & $\begin{array}{l}1145 \\
1196 \\
1210\end{array}$ \\
\hline $\begin{array}{l}\text { LIEC28 } \\
\text { LIEC } 29\end{array}$ & $\begin{array}{l}1223 \\
1246\end{array}$ & $\begin{array}{l}1330 \\
1348\end{array}$ & $\begin{array}{l}1422 \\
1445\end{array}$ & $\begin{array}{l}1395 \\
1428\end{array}$ & $\begin{array}{l}1086 \\
1115\end{array}$ & $\begin{array}{l}1422 \\
1471\end{array}$ & $\begin{array}{l}1150 \\
1152\end{array}$ & $\begin{array}{l}12+3 \\
1277\end{array}$ \\
\hline IIEC 30 & 1265 & 1369 & 1474 & 1460 & 1146 & 1524 & 1156 & $130 \%$ \\
\hline IIEC31 & 1274 & 1394 & 1494 & 1482 & 1174 & 1569 & 1157 & 1333 \\
\hline $\begin{array}{l}\text { JANO } 1 \\
\text { JANOI }\end{array}$ & $\begin{array}{l}1297 \\
1344\end{array}$ & $\begin{array}{l}1424 \\
1450\end{array}$ & $\begin{array}{l}1524 \\
1551\end{array}$ & $\begin{array}{l}1510 \\
1531\end{array}$ & $\begin{array}{l}1200 \\
1223\end{array}$ & $\begin{array}{l}1600 \\
1630\end{array}$ & $\begin{array}{l}11.69 \\
1199\end{array}$ & $\begin{array}{l}1365 \\
1391\end{array}$ \\
\hline JANO3 & 1390 & 1477 & 1572 & 1540 & 1254 & 1658 & 1229 & 14.13 \\
\hline JANO 4 & 1428 & 1507 & 1614 & 1561 & 1284 & 1683 & 1265 & 1433 \\
\hline JANOS & 1461 & 1539 & 1657 & 1588 & 1307 & 1707 & 1300 & 1467 \\
\hline JANO G & 1492 & 1570 & 1685 & 1598 & 1326 & 1738 & 1334 & 1501 \\
\hline JANO 7 & 1528 & 1596 & 1723 & 1622 & 1341 & 1755 & 1363 & $153 \%$ \\
\hline JANOB & 1577 & 1626 & 1758 & 1659 & 1366 & 1778 & 1395 & 1547 \\
\hline JANOQ & 1622 & 1652 & 1790 & 1698 & 1381 & 1795 & 1427 & 1613 \\
\hline JAN1O & 1665 & 1675 & 1832 & 1756 & 1395 & 1824 & 1455 & 1642 \\
\hline JAN 11 & 1708 & 1695 & 1875 & 1811 & 1421 & 1870 & 1492 & 1668 \\
\hline JAN12 & $\begin{array}{l}1738 \\
1767\end{array}$ & $\begin{array}{l}1727 \\
1748\end{array}$ & 1921 & 1860 & 1455 & 1903 & 1532 & 1687 \\
\hline JAN14 & 1804 & 1767 & 1973 & 1952 & 1501 & 1965 & 1603 & 1747 \\
\hline JAN15 & 1851 & 1784 & 2002 & 1990 & 1534 & 2002 & 1645 & 1772 \\
\hline JAN16 & 1879 & 1797 & 2038 & 2038 & 1566 & 2037 & 1681 & 1788 \\
\hline JAN17 & 1900 & 1806 & 2076 & 2102 & 1602 & 2067 & 1714 & 1300 \\
\hline JAN18 & 1930 & 1822 & 2104 & 2145 & 1641 & 2112 & 1743 & 1808 \\
\hline JAN19 & 1957 & 1841 & 2129 & 2162 & 1678 & 2169 & 1785 & 1831 \\
\hline JAN2O & 1979 & 1858 & 2153 & 2182 & 1714 & 2226 & 1855 & 1853 \\
\hline JAN21 & 2010 & 1883 & 2177 & 2198 & 1742 & 2286 & 1921 & 1366 \\
\hline JAN22 & 2049 & 1906 & 2204 & 2210 & 1766 & 2332 & 1969 & 1885 \\
\hline JAN23 & 2080 & 1939 & 2231 & 2231 & 1792 & 2361 & 2010 & 1911. \\
\hline JAN24 & 2113 & 1958 & 2253 & 2265 & 1820 & 2383 & 2038 & 1936 \\
\hline JAN2S & 2153 & 1972 & 2266 & 2295 & 1846 & 2411 & 2076 & $195 \%$ \\
\hline JAN2G & 2185 & 1991 & 2271 & 2339 & 1873 & 2437 & 2122 & 1997 \\
\hline JAN27 & 2216 & 2019 & 2289 & 2371 & 1898 & 2460 & 2160 & $205 \%$ \\
\hline JAN2B & 2250 & 2052 & 2311 & 2390 & 19.22 & 2497 & 2200 & 2100 \\
\hline JAN29 & 2287 & 2090 & 2337 & 2413 & 1942 & 2519 & 2244 & 2126 \\
\hline JAN3O & 2321 & 2128 & 2371 & 2419 & 1961 & 2544 & 2271 & 2163 \\
\hline JAN31 & 2362 & 2171 & 2403 & 2438 & 1780 & 2377 & 2303 & $218 \%$ \\
\hline FEEO1 & 2408 & 2216 & 2425 & 2469 & 1994 & 2503 & 2351 & 2192 \\
\hline FEEO2 & 2450 & 2259 & 2462 & 2496 & 201.2 & 2622 & 2399 & 2199 \\
\hline FEBO3 & 2480 & 2297 & 2503 & 2521 & 2043 & 2643 & 2449 & 2200 \\
\hline FEBO4 & 2515 & 2338 & 2541 & 2554 & 2074 & 2667 & 2486 & 2200 \\
\hline FEBOS & 2559 & 2375 & 2580 & 2579 & 2105 & 2703 & 2513 & 2205 \\
\hline FEEOS & 2596 & 2410 & 2607 & 2621 & 2131 & 2752 & 2550 & 2216 \\
\hline FEEOT & 2637 & 2444 & 2634 & 2661 & 2162 & 2800 & 2594 & 2237 \\
\hline FEEOB & 2680 & 2478 & 2667 & 2691 & 2192 & 2035 & 2638 & 2261 \\
\hline FEEO 9 & 2732 & 2513 & 2700 & 2726 & 2211 & 2858 & 2674 & 2291 \\
\hline FEE 10 & 2784 & 2551 & 2717 & 2775 & 2231 & 2069 & 2693 & 2330 \\
\hline FEE11 & 2824 & 2588 & 2761 & 2809 & 2255 & 2872 & 2720 & 2374 \\
\hline FEB 12 & 2853 & 2624 & 2813 & 2344 & 2279 & 2376 & 2757 & 2416 \\
\hline FE 313 & 2887 & 2658 & 2851 & 2875 & 2306 & 2891 & 2792 & 2459 \\
\hline FEB 14 & 2906 & 2580 & 2878 & 2900 & 2331 & 2706 & 2326 & 2491 \\
\hline FEE15 & 2920 & 2699 & 2897 & 2915 & 2356 & 2922 & 2867 & 2530 \\
\hline FEE 16 & 2958 & 2732 & 2811 & 2819 & 2376 & 2732 & 2900 & $254 \%$ \\
\hline FEE 17 & 2992 & 2775 & 2915 & 2932 & 2395 & 2944 & 2923 & 2553 \\
\hline FEE 18 & 3028 & 2808 & 2926 & 2747 & 2417 & 2957 & 2949 & 2558 \\
\hline FEE & 3070 & 2830 & 2928 & $\begin{array}{r}296 ? \\
3-3\end{array}$ & 2434 & $29 \leq 8$ & 2973 & 2564 \\
\hline
\end{tabular}


$--78 / 79---79 / 80$

$\cdots-\cdots 80 / 81-\cdots 81 / 82 \cdots-\cdots 2 / 83$

$-\cdots .33 / 84 \cdots \cdots 34 / 85 \cdots \cdots-\cdots 85 / 8$

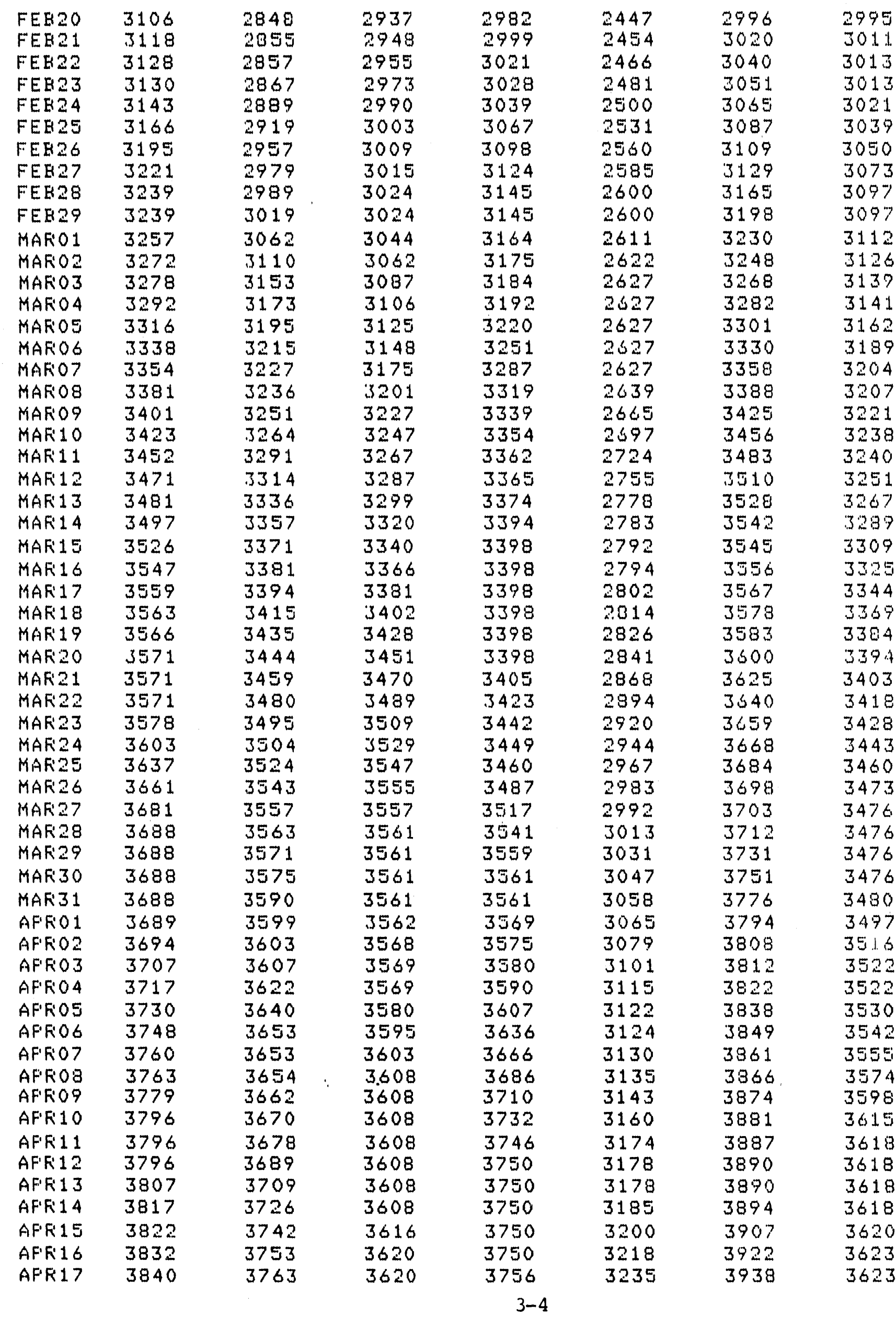

257

258 .

261

$263:$

265

268

269

$271:$

274

2748

278

280 .

282.

285.

287.

$28 \%$

292

294

295

275

286

$296 \div$

$296 i$

277

298

299

301

301.

302.

3055

3090

$311:$

$313:$

314

$314:$

31 is?

3160

317

$317 i$

317

318

3180

3186

3180

3180

3180

3181

$318:$

$319:$

320 .

321.

322.

322.

322.

323.

$325:$

$325:$ 
$--78 / 79---79 / 80$

$---80 / 81----81 / 82----82 / 83----83 / 84---84 / 85-\cdots--85 / 86--$

\begin{tabular}{|c|c|c|c|c|c|c|c|c|}
\hline $\begin{array}{l}\text { AF'R'18 } \\
\text { AF'Fi } 19\end{array}$ & $\begin{array}{l}3847 \\
3854\end{array}$ & $\begin{array}{l}3765 \\
3767\end{array}$ & $\begin{array}{l}3620 \\
3620\end{array}$ & $\begin{array}{l}3767 \\
3772\end{array}$ & $\begin{array}{l}3258 \\
3285\end{array}$ & $\begin{array}{l}3947 \\
3956\end{array}$ & $\begin{array}{l}3623 \\
3623\end{array}$ & $\begin{array}{l}3272 \\
3282\end{array}$ \\
\hline$A F F \geq 0$ & 3856 & 3767 & 3626 & 3777 & 3309 & 3966 & 3623 & 3284 \\
\hline$A F F^{\prime} 21$ & 3856 & 3767 & 3636 & 3792 & 3328 & 3966 & 3623 & 3292 \\
\hline$A F^{\prime} F I 2$ & 3856 & 3767 & 3638 & 3805 & 3341 & 3767 & 3623 & 3305 \\
\hline$A F F=3$ & 3856 & 3767 & 3641 & 3820 & 3353 & 3983 & 3623 & 3323 \\
\hline$A F F: 24$ & 3856 & 3767 & 3649 & .3830 & 3363 & 3990 & 3623 & 3341 \\
\hline AFK 125 & 3856 & 3782 & 3658 & 3834 & 3373 & 3990 & 3625 & 3350 \\
\hline$A F F 26$ & 3863 & 3791 & 3658 & 3836 & 3379 & 3990 & 3625 & 3350 \\
\hline AFIFI 27 & 3871 & 3801 & 3658 & 3845 & 3380 & 3990 & 3625 & 3350 \\
\hline AF'FI 28 & 3883 & 3809 & 3658 & 3855 & 3380 & 3990 & 3625 & 3350 \\
\hline AFFIIS & 3894 & 3821 & 3658 & 3867 & 3380 & 3990 & 3625 & $3 \times 50$ \\
\hline$A F^{\prime} F 30$ & 3901 & 3830 & 3658 & 3870 & 3380 & 3996 & 3625 & 3354 \\
\hline
\end{tabular}


APPENDIX 4

SURVEY FORM 
NAME : PHONE NO.

LOG \#

ADDRESS :

ZIP CODE

1. During the past 12 months, have you drastically altered your energy use pattern by addition(s) to your house, energy conservation measure(s), or practice(s). If so, describe.

2. Are you the original owner or renter? (Check one)

() Yes ( ) No

3. How many people live permanently in your home?

4. How many children?

( ) Preschoolers

( ) Teenagers

5. How many persons are home during the day? (\# of peon (\# of people)

() Senior Citizens

( ) Yes

( ) No

7. Is there a dishwasher in your household? (Check one)

( ) Yes

( ) No

8. Do you have a clothes dryer? (Check one)

( ) Yes

( ) No

9. Is the water heater located in an area that is normally heated or an area normally not heated? (Check one)

( ) Heated

( ) Not Heated

10. How many water heaters do you have?

( ) Electric

( ) Gas

11. Do you have a swimming pool? (Check one)

( ) Yes

() No

12. (If Yes) Is it heated? (Check one.

( ) Yes

( ) No

13. (If heated) By what fuel? (Check one)

( ) Electric

( ) Gas

14. Do you have flood lights? (Check one)

( ) Yes

( ) No

15. (If Yes) when do you bu:in them? (Check one)

() All night

( ) When away at night from the house

( ) They are on a timer and go off at

16. Do you have a water well? (Check one)

( ) Yes

( ) No

17. Other additional Euel loads?

(\# of heaters) 
Residential Questionnaire Page 2

18. At what temperature do you usually set your thermostat... . ? In Winter?

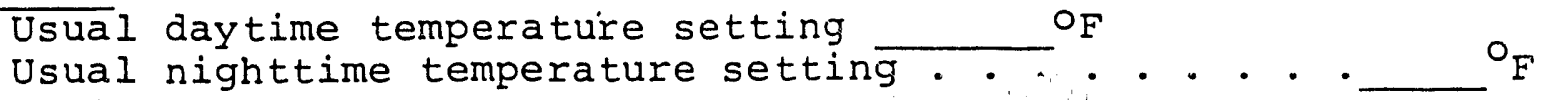

In Summer?

() Turn off furnace in summer
Usual daytime temperature setting ${ }^{O_{F}}$
Usual nighttime temperature setting... $\cdot . \cdot . \cdot{ }^{\circ}{ }_{F}$

19. Do you use any other heating source such as wood stove, heatalator fireplace, room electric heaters, etc..? (Check one)
() Yes
( ) No

20. (If yes) Degree of use: How often? ( ) often ( ) Seldom () Never

When?

21. Do you consider this a major source of heat? (check one)
( ) Yes

( ) No

22. (If yes) What kind of heating is it and what fuel does it use? Kind of heating ( ) Don't know

Fuel Source

23. About how many times a day are the outside doors to your home opened on the average? (Check one)

( ) Less than 6 times a day

( ) 6 to 13 times a day

( ) More than 13 times a day

24. Are your floors carpeted? (Check one)

() $0-25 \%$

( ) $25-508$

() $50-75 \%$

() $75-1008$

THANK YOU VERY MUCH FOR COMPLETING THIS QUESTIONNAIRE. 
APPENDIX 5

THEORETICAL HEATING AND COOLING LOAD ANALYSES 
TENNESSEE VALLEY AUTHORITY WHOLE HOUSE LOAD CALCULATION MANUAL J SEVENTH ED.

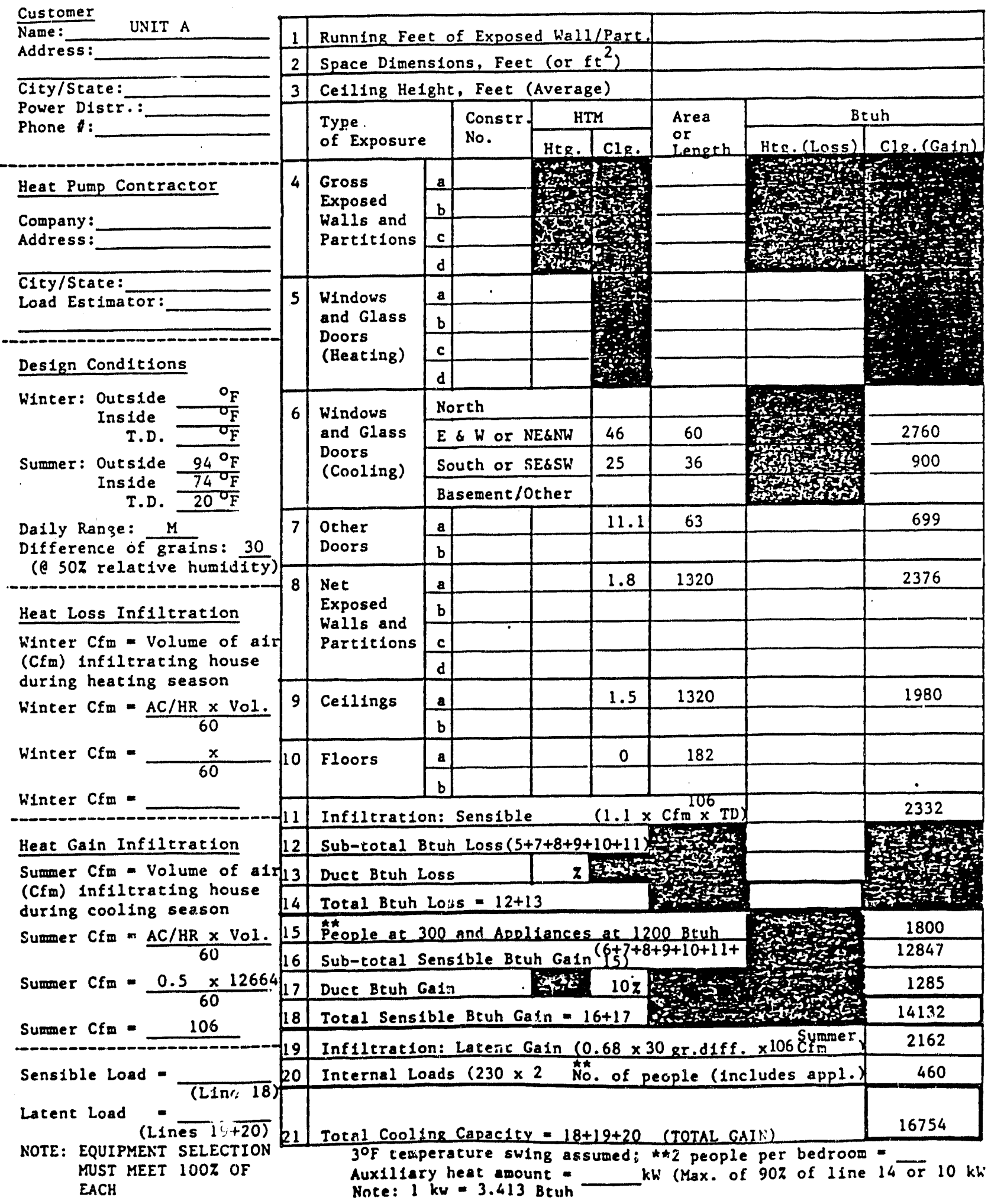


WATT-COUNT ENGINEERING SYSTEMS

HEAT LOSS AND GAIN ANALYSIS

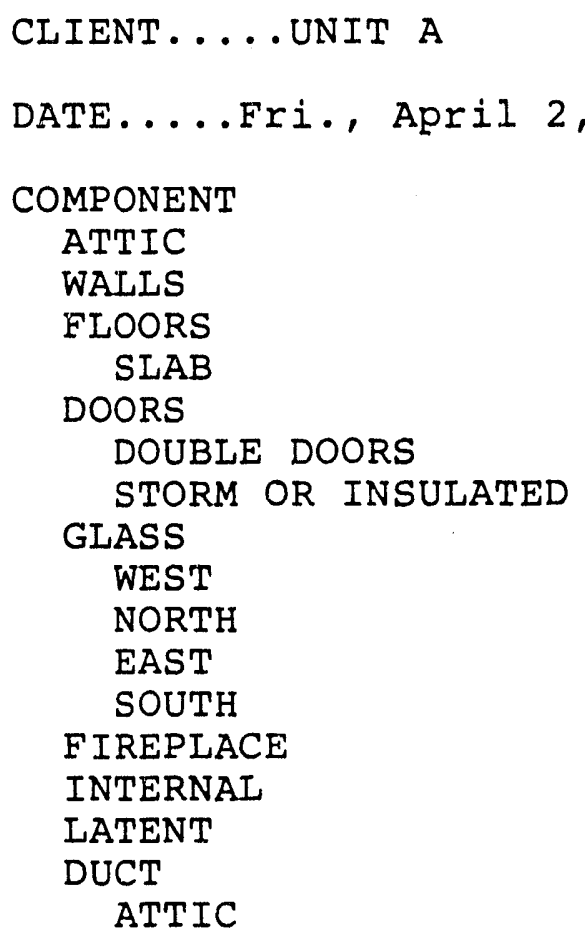

TOTAL
HEATING

3,007

5,283

10,010

3,440

1,460

2,851

1,053

1,879

0

650

1,200

4,329

$----$

36,138
LIVING AREA....1583

TIME ...15.55.11

COOLING

AREA

1,503

3,287

1,583

1,320

0

182

486

123

0

2,130

260

570

0

300

1,784

4,992

1,430

100

17,317 
IENNESSEE VALLEY AUTHORITY WHOLE HOUSE LOAD CALCULATION MANTJAL J SEVENTH ED.

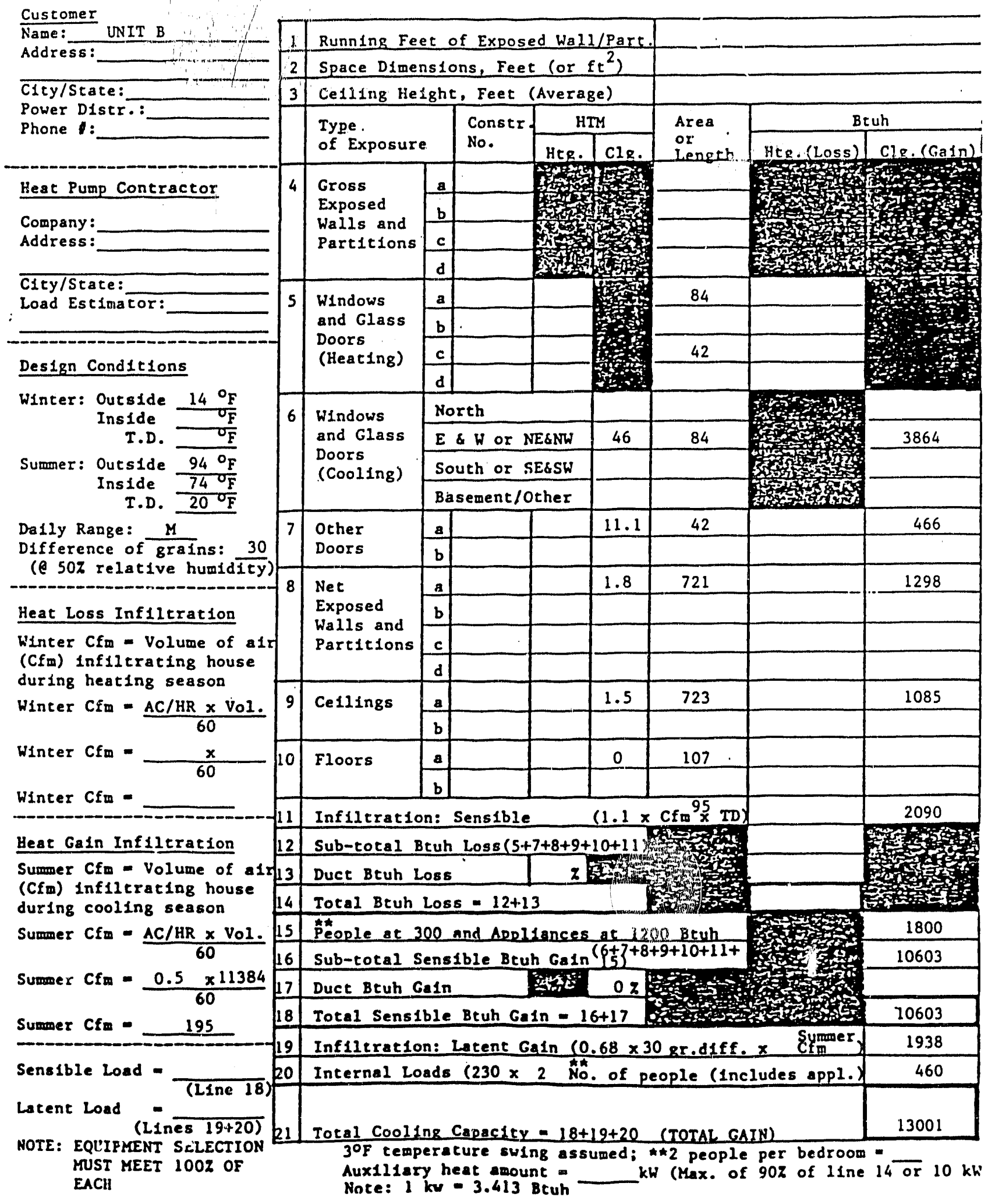


WATT-COUNT ENGINEERING SYSTEMS

HEAT LOSS AND GAIN ANALYSIS

\begin{tabular}{|c|c|c|c|}
\hline CIIENT.....UNIT B & & LIVING &. .1423 \\
\hline DATE.....Fri., April 2, & 1982 & TIME.. & 30 \\
\hline COMPONENT & HEATING & COOLING & AREA \\
\hline ATTIC & 1,373 & 686 & 723 \\
\hline WALLS & 6,435 & 4,005 & 1,610 \\
\hline FLOORS & & & \\
\hline SIAB & 5,885 & 0 & 107 \\
\hline DOORS & & & \\
\hline STORM OR INSULATED & 2,920 & 246 & 2 \\
\hline GLASS & 0 & 0 & 0 \\
\hline WEST & 4,309 & 3,210 & 54 \\
\hline NORTH & & 0 & 0 \\
\hline EAST & 2,365 & 720 & 30 \\
\hline SOUTH & 0 & 0 & 0 \\
\hline INFILTRATION & & & \\
\hline BETWEEN FLOORS & 1,365 & 630 & 723 \\
\hline F IREPLACE & 2,275 & 300 & 1 \\
\hline INTERNAL & 1,200 & 1,746 & 4 \\
\hline LATENT & & 4,720 & \\
\hline DUCT & & & \\
\hline ATTIC & 1,454 & 682 & 40 \\
\hline TOTAL & 29,582 & 16,947 & \\
\hline
\end{tabular}


IENNESSEE VALLEY AUTHORITY WHOLE HOUSE LOAD CALCURATION MANUAL J SEVENTH ED.

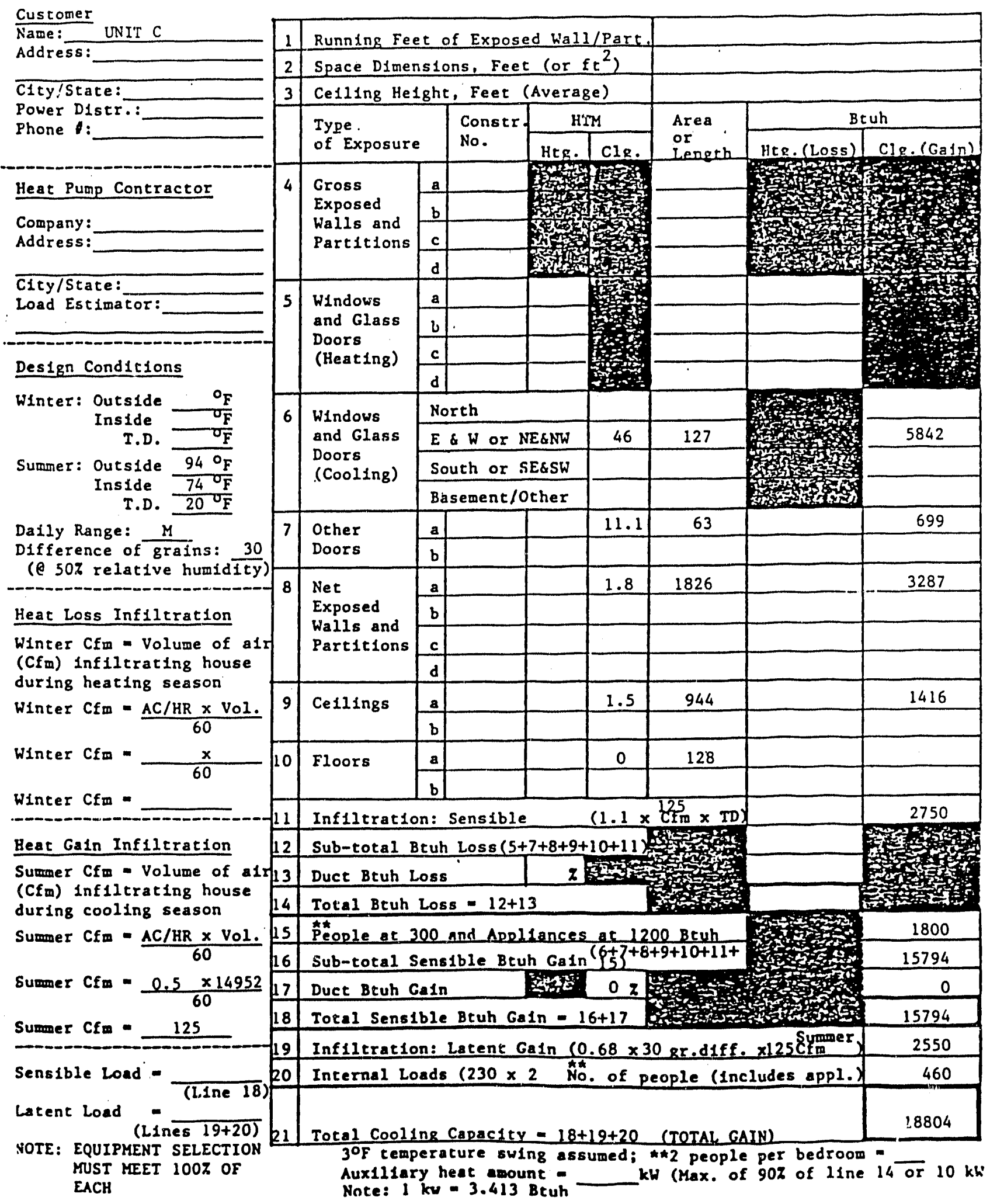


WATT-COUNT ENGINEERING SYSTEMS

HEAT LOSS AND GAIN ANALYSIS

\begin{tabular}{|c|c|c|c|}
\hline CLIENT.... . UNIT C & & LIVING & $\ldots 859$ \\
\hline DATE.....MOn., April 5, & 1982 & TIME. . & .38 \\
\hline COMPONENT & HEATING & COOLING & AREA \\
\hline ATTIC & 1,793 & 896 & 944 \\
\hline WALLS & 6,657 & 4,246 & \\
\hline FLOORS & & & \\
\hline SLAB & 7,040 & 0 & 128 \\
\hline DOORS & & & \\
\hline DOUBLE DOORS & 3,440 & 486 & \\
\hline STORM OR INSULATED & 1,460 & 123 & \\
\hline GLASS & 0 & 0 & \\
\hline WEST & 5,945 & 4,440 & \\
\hline NORTH & 0 & 0 & \\
\hline EAST & 4,147 & 1,270 & 52 \\
\hline SOUTH & 0 & 0 & \\
\hline INFILTRATION & & & \\
\hline BETWEEN FLOORS & 1,495 & 690 & \\
\hline FIREPLACE & 650 & 300 & \\
\hline INTERNAL & 1,200 & 1,845 & \\
\hline LATENT & & 5,366 & \\
\hline DUCT & & & \\
\hline ATTIC & 1,781 & 743 & \\
\hline TOTAL & 35,609 & 20,407 & \\
\hline
\end{tabular}


WATT-COUNT ENGINEERING SYSTEMS

HEAT LOSS AND GAIN ANALYSIS

\begin{tabular}{|c|c|c|c|}
\hline \multicolumn{2}{|l|}{ CLIENT..... HERITAGE SQUARE } & \multicolumn{2}{|c|}{ LIVING AREA....1089 } \\
\hline DATE.....July 9, 1980 & & TIME.. & .00 \\
\hline $\begin{array}{l}\text { COMPONENT } \\
\text { ATTIC } \\
\text { WALLS } \\
\text { FLOOR } \\
\text { DOORS } \\
\text { FIREPLACE } \\
\text { WINDOWS } \\
\text { EAST } \\
\text { SOUTH } \\
\text { WEST } \\
\text { NORTH } \\
\text { INTERNAL } \\
\text { LATENT } \\
\text { DUCT LOSS }\end{array}$ & $\begin{array}{c}\text { HEATING } \\
1,633 \\
4,885 \\
3,152 \\
3,895 \\
2,275 \\
9,295\end{array}$ & $\begin{array}{c}\text { COOLING } \\
1,089 \\
2,456 \\
\\
898 \\
700 \\
\\
1,375 \\
575 \\
2,520 \\
460 \\
2,504 \\
5,628 \\
1.359\end{array}$ & $\begin{array}{r}\text { AREA } \\
1,089 \\
1,152 \\
1,089 \\
42 \\
1 \\
55 \\
23 \\
42 \\
23\end{array}$ \\
\hline TOTALS & 32,235 & 19,564 & \\
\hline
\end{tabular}


WATT-COUNT ENGINEERING SYSTEMS

HEAT LOSS AND GAIN ANALYSIS

\begin{tabular}{|c|c|c|c|}
\hline CLIENT.....HERITAGE SQU & & IIVIN & .1002 \\
\hline DATE.....JulY 9, 1980 & & TIME. & .00 \\
\hline COMPONENT & HEATING & COOLING & AREA \\
\hline ATTIC & 1,403 & 1,002 & 1,002 \\
\hline WALLS & 3,312 & 2,208 & 1,104 \\
\hline FLOOR & 5,010 & 0 & 1,002 \\
\hline DOORS & 1,785 & 273 & 21 \\
\hline FIREPLACE & & 0 & 1 \\
\hline WINDOWS & & & \\
\hline EAST & 850 & 5,400 & 108 \\
\hline INTERNAI & & 2,700 & \\
\hline LATENT & & 3,475 & \\
\hline DUCT LOSS & 2,009 & 1,506 & \\
\hline TOTALS & 22,089 & 16,564 & \\
\hline
\end{tabular}


WATT-COUNT ENGINEERING SYSTEMS

HEAT LOSS AND GAIN ANALYSIS

\begin{tabular}{|c|c|c|c|}
\hline CLIENT..... HERITAGE SQU & & LIVING & .1077 \\
\hline DATE......August 8,1980 & & TIME. . & .00 \\
\hline COMPONENT & HEATING & COOLING & AREA \\
\hline ATTIC & 1,647 & 1,098 & 1,098 \\
\hline WALLS & 4,542 & 2,285 & 1,112 \\
\hline FLOOR & 2,745 & & 1,098 \\
\hline DOORS & 5,875 & 1,357 & 63 \\
\hline FIREPLACE & 2,275 & 700 & \\
\hline WINDOWS & 12,209 & & \\
\hline EAST & & 1,369 & 5 \\
\hline SOUTH & & 1,752 & \\
\hline WEST & & 686 & 1 \\
\hline NORTH & & 514 & \\
\hline INTERNAL & 2,000 & 2,004 & \\
\hline LATENT & & 5,774 & \\
\hline DUCT LOSS & 2,019 & 528 & \\
\hline TOTALS & 33,312 & 17,716 & \\
\hline
\end{tabular}


APPENDIX 6

ENERGY USAGE DATA OF BRENTWOOD POINTE

AND HERITAGE SQUARE FOR 1985-86

(See Volume 2) 


\section{APPENDIX 7}

NATIONAL OCEANIC AND ATMOSPHERIC ADMINISTRATION WEATHER DATA FOR NASHVILLE, TENNESSEE 1985-86 


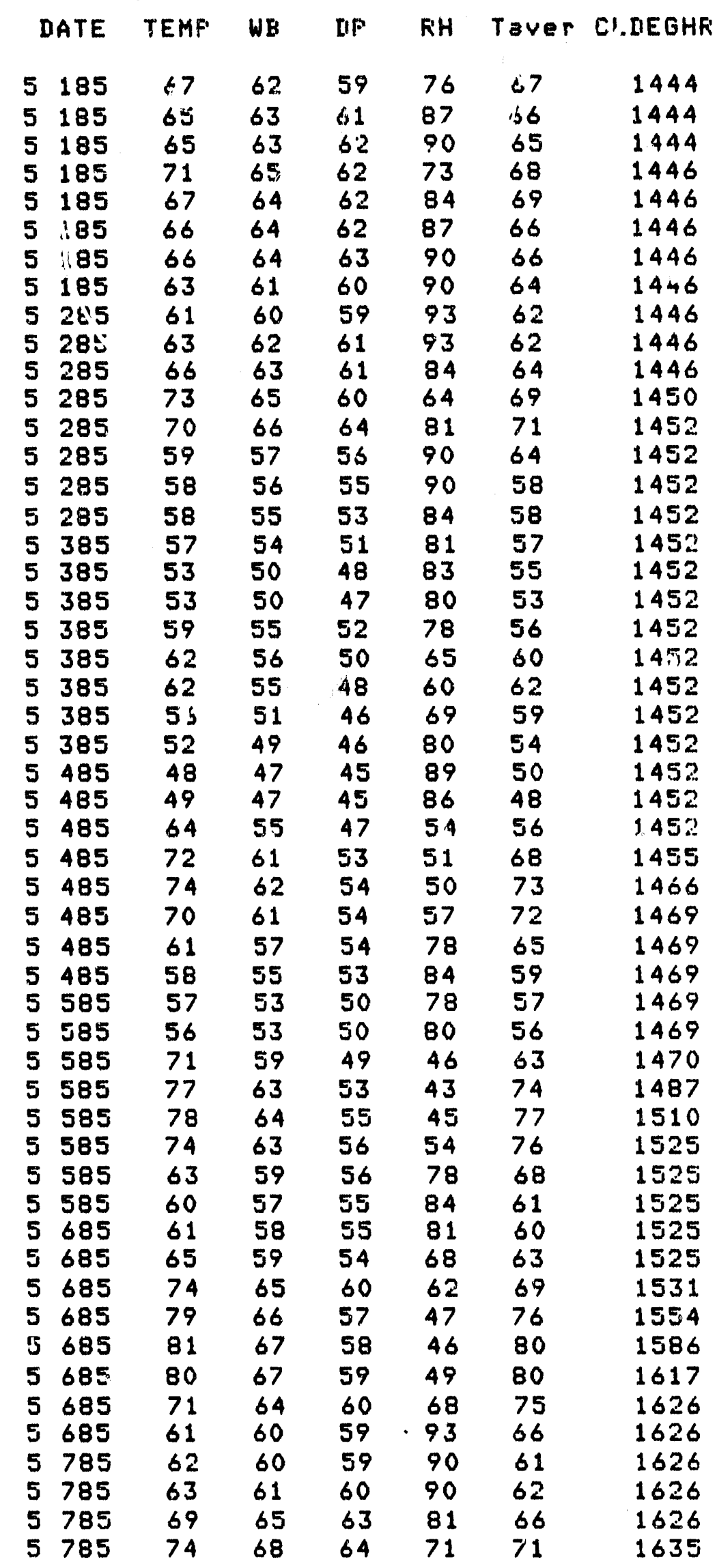




\begin{tabular}{|c|c|c|c|c|c|c|}
\hline DATE & TEMP & WB & 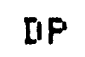 & FH & Taver & CLIIEGH \\
\hline 5785 & 74 & 65 & 59 & 60 & 74 & 1647 \\
\hline 5785 & 66 & 61 & 57 & 73 & 70 & 1547 \\
\hline 5785 & 63 & 60 & 58 & 84 & 64 & 1647 \\
\hline 5785 & 62 & 59 & 57 & 84 & 62 & 1647 \\
\hline 5885 & 60 & 57 & 55 & 84 & 61 & 1647 \\
\hline 5885 & 58 & 54 & 51 & 78 & 59 & 1647 \\
\hline 5885 & 62 & 57 & 52 & 70 & 60 & 1647 \\
\hline 5885 & 70 & 61 & 54 & 57 & 66 & 1647 \\
\hline 5885 & 71 & 62 & 56 & 59 & 70 & 1649 \\
\hline 5885 & 68 & 60 & 55 & 63 & 69 & 1649 \\
\hline 5885 & 62 & 58 & 54 & 75 & 65 & 1649 \\
\hline 5885 & 56 & 54 & 53 & 90 & 59 & 1649 \\
\hline 5985 & 56 & 54 & 53 & 90 & 56 & 1649 \\
\hline 5985 & 54 & 54 & 53 & 96 & 55 & 1649 \\
\hline 5985 & 68 & 62 & 57 & 68 & 61 & 1649 \\
\hline 5985 & 69 & 61 & 56 & 63 & 68 & 1649 \\
\hline 5985 & 69 & 62 & 58 & 68 & 69 & 1649 \\
\hline 5985 & 68 & 62 & 58 & 71 & 68 & 1649 \\
\hline 5985 & 67 & 62 & 58 & 73 & 67 & 1649 \\
\hline 5985 & 63 & 60 & 58 & 84 & 65 & 1649 \\
\hline 51085 & 62 & 60 & 58 & 87 & 62 & 1649 \\
\hline 51085 & 63 & 60 & 58 & 84 & 62 & 1649 \\
\hline 51085 & 66 & 62 & 60 & 81 & 64 & 1649 \\
\hline 51085 & 68 & 64 & 61 & 78 & 67 & 1649 \\
\hline 51085 & 75 & 67 & 62 & 64 & 71 & 1659 \\
\hline 51085 & 73 & 67 & 63 & 71 & 74 & 1669 \\
\hline 51085 & 67 & 65 & 63 & 87 & 70 & 1669 \\
\hline 51085 & 61 & 59 & 58 & 90 & 64 & 1669 \\
\hline 51185 & 60 & 58 & 57 & 50 & 60 & 1669 \\
\hline 51185 & 62 & 60 & 58 & 87 & 61 & 1669 \\
\hline 51185 & 71 & 67 & 64 & 79 & 66 & 1671 \\
\hline 51185 & 76 & 67 & 61 & 60 & 73 & 1685 \\
\hline 51185 & 81 & 68 & 60 & 49 & 78 & 1714 \\
\hline 51185 & 75 & 66 & 61 & 62 & 78 & 1734 \\
\hline 51185 & 70 & 65 & 61 & 73 & 72 & 1737 \\
\hline 51185 & 69 & 65 & 62 & 79 & 69 & 1737 \\
\hline 51285 & 68 & 64 & 62 & 81 & 68 & 1737 \\
\hline 51285 & 69 & 66 & 64 & 84 & 68 & 1737 \\
\hline 51285 & 76 & 70 & 66 & 71 & 72 & 1750 \\
\hline 51285 & 85 & 74 & 68 & 57 & 80 & 1788 \\
\hline 51285 & 87 & 70 & 61 & 42 & 86 & 1838 \\
\hline 51285 & 80 & 68 & 61 & 52 & 83 & 1873 \\
\hline 51285 & 72 & 66 & 63 & $7 \overline{3}$ & 76 & 1885 \\
\hline 51285 & 67 & 65 & $\leqslant 3$ & 87 & 69 & 1885 \\
\hline 51385 & 65 & 64 & 6 & 93 & 66 & 1885 \\
\hline 51385 & 67 & 65 & 63 & 87 & 66 & 1885 \\
\hline 51385 & 82 & 73 & 68 & 63 & 74 & 1910 \\
\hline 51385 & 87 & 74 & 67 & 52 & 84 & 1957 \\
\hline 51385 & 87 & 71 & 63 & 45 & 87 & 2008 \\
\hline 31385 & 83 & 71 & 65 & 55 & 85 & 2050 \\
\hline 5138.5 & 74 & 69 & 66 & 76 & 78 & 2069 \\
\hline & 74 & 68 & & 71 & 74 & 2081 \\
\hline 51485 & 72 & 67 & 64 & 76 & 73 & 2088 \\
\hline
\end{tabular}




$\begin{array}{lllllll}\text { DATE } & \text { TEMF } & \text { WB } & \text { DF } & \text { FH } & \text { T BVer CLDEGHF } \\ 51485 & 72 & 68 & 66 & 82 & 72 & 2054 \\ 51485 & 81 & 73 & 69 & 67 & 76 & 2121 \\ 51485 & 88 & 73 & 66 & 48 & 84 & 2169 \\ 51485 & 89 & 74 & 66 & 47 & 88 & 2226 \\ 51485 & 77 & 71 & 68 & 74 & 83 & 2256 \\ 51485 & 73 & 68 & 65 & 76 & 75 & 2268 \\ 51485 & 69 & 66 & 64 & 84 & 71 & 2269 \\ 51585 & 71 & 65 & 61 & 71 & 70 & 2271 \\ 51585 & 70 & 62 & 56 & 61 & 70 & 2271 \\ 51585 & 71 & 60 & 52 & 51 & 70 & 2274 \\ 51585 & 77 & 62 & 52 & 42 & 74 & 2290 \\ 51585 & 75 & 62 & 53 & 46 & 76 & 2307 \\ 51585 & 71 & 59 & 50 & 48 & 73 & 2313 \\ 51585 & 61 & 56 & 52 & 72 & 66 & 2313 \\ 51585 & 56 & 54 & 52 & 87 & 58 & 2313 \\ 51685 & 56 & 53 & 50 & 80 & 56 & 2313 \\ 51685 & 60 & 56 & 53 & 78 & 58 & 2313 \\ 51685 & 74 & 62 & 53 & 48 & 67 & 2319 \\ 51685 & 79 & 65 & 56 & 45 & 76 & 2342 \\ 51685 & 79 & 62 & 49 & 35 & 79 & 2369 \\ 51685 & 72 & 60 & 50 & 46 & 75 & 2380 \\ 51685 & 65 & 56 & 49 & 56 & 68 & 2380 \\ 51685 & 63 & 56 & 50 & 63 & 64 & 2380 \\ 51785 & 60 & 56 & 53 & 78 & 61 & 2380 \\ 51785 & 59 & 57 & 55 & 87 & 59 & 2380 \\ 51785 & 60 & 57 & 55 & 84 & 59 & 2380 \\ 51785 & 62 & 57 & 53 & 73 & 61 & 2380 \\ 51785 & 13 & 56 & 50 & 63 & 62 & 2380 \\ 51785 & 60 & 54 & 49 & 67 & 61 & 2380 \\ 51785 & 57 & 52 & 47 & 69 & 58 & 2380 \\ 51785 & 55 & 51 & 47 & 75 & 56 & 2380 \\ 51885 & 53 & 48 & 43 & 69 & 54 & 2380 \\ 51885 & 53 & 49 & 46 & 77 & 53 & 2380 \\ 51885 & 60 & 53 & 46 & 60 & 56 & 2380 \\ 51885 & 66 & 54 & 44 & 45 & 63 & 2380 \\ 51885 & 72 & 56 & 41 & 33 & 69 & 2383 \\ 51885 & 70 & 55 & 42 & 36 & 71 & 2385 \\ 51885 & 56 & 51 & 46 & 69 & 63 & 2385 \\ 51885 & 51 & 49 & 46 & 83 & 53 & 2385 \\ 51985 & 47 & 46 & 44 & 89 & 49 & 2385 \\ 51985 & 51 & 49 & 46 & 83 & 49 & 2385 \\ 51985 & 71 & 59 & 50 & 48 & 61 & 2386 \\ 51985 & 78 & 59 & 44 & 30 & 74 & 2405 \\ 51985 & 82 & 60 & 43 & 25 & 80 & 2438 \\ 51985 & 78 & 60 & 45 & 31 & 80 & 2465 \\ 51985 & 63 & 55 & 49 & 61 & 70 & 2466 \\ 51985 & 56 & 52 & 48 & 75 & 59 & 2466 \\ 52085 & 52 & 50 & 48 & 86 & 54 & 2466 \\ 52085 & 58 & 54 & 50 & 75 & 55 & 2466 \\ 52085 & 77 & 63 & 54 & 45 & 67 & 2476 \\ 52085 & 81 & 65 & 54 & 39 & 79 & 2506 \\ 52085 & 83 & 67 & 58 & 43 & 82 & 2544 \\ 52085 & 79 & 67 & 59 & 51 & 81 & 2574\end{array}$




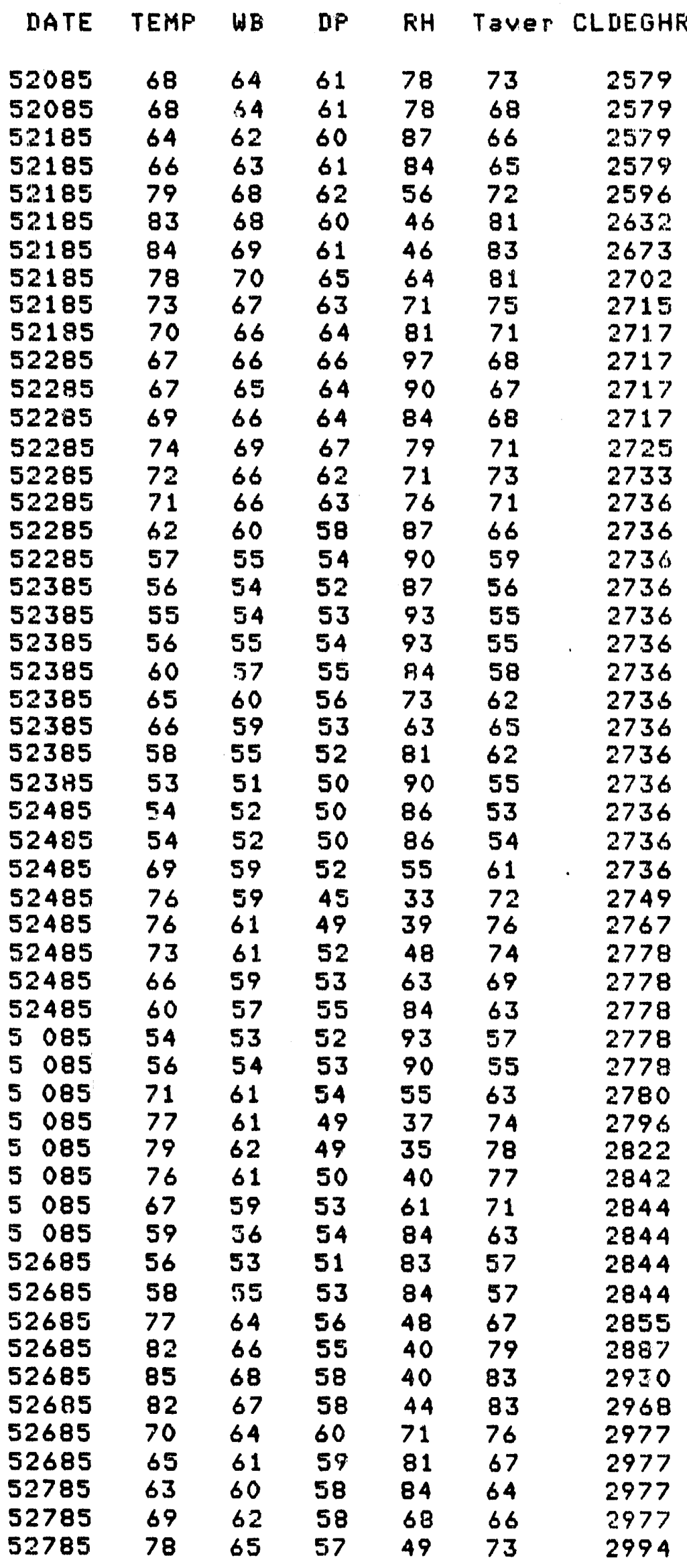




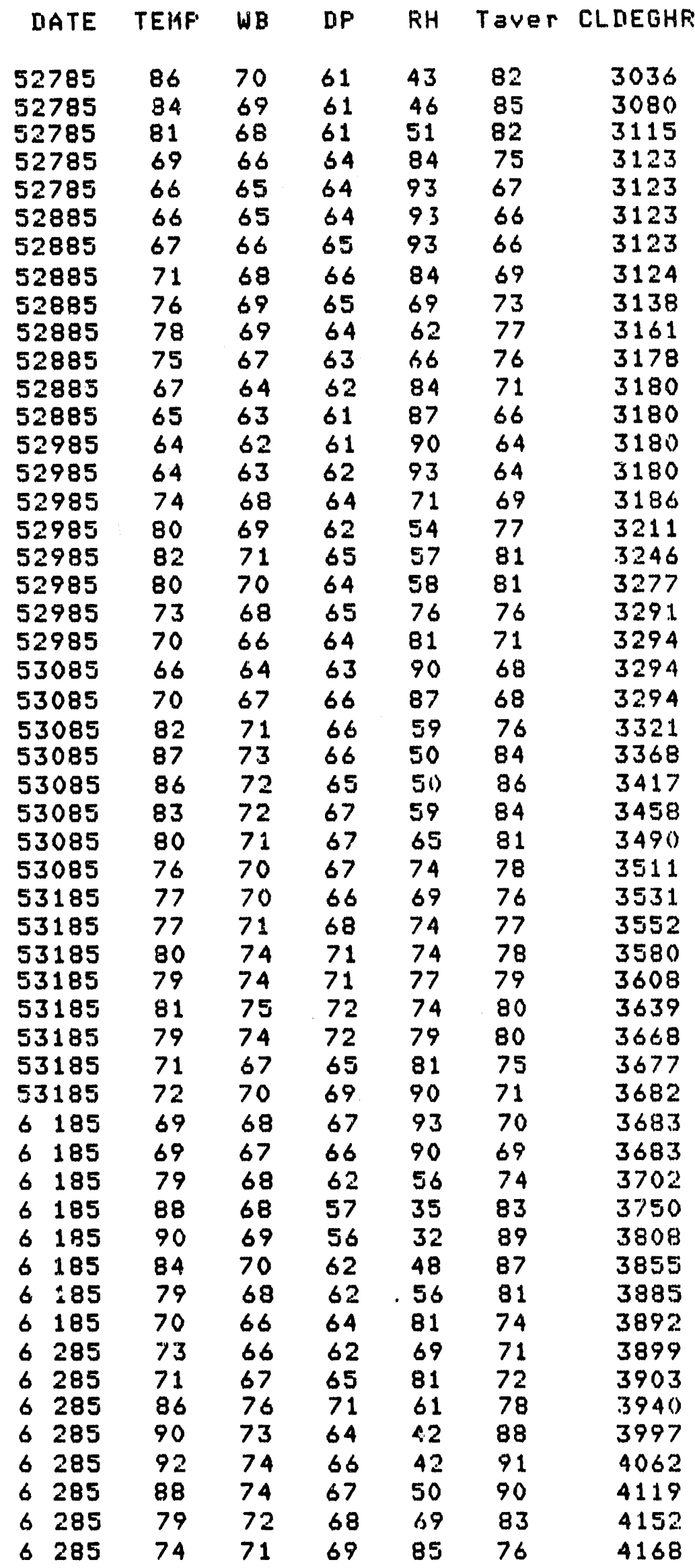




\begin{tabular}{|c|c|c|c|c|c|c|}
\hline DATE & TEKP & WB & IP & RH & Taver & CLDEGHF \\
\hline 6385 & 69 & 67 & 65 & 87 & 71 & 4170 \\
\hline 6385 & 70 & 67 & 66 & 87 & 69 & 4170 \\
\hline 6385 & 87 & 75 & 69 & 55 & 78 & 4209 \\
\hline 6385 & 92 & 77 & 70 & 49 & 89 & 4271 \\
\hline 6385 & 90 & 76 & 69 & 50 & 91 & 4332 \\
\hline 6385 & 83 & 75 & 72 & 70 & 86 & 4377 \\
\hline 6385 & 74 & 69 & 67 & 79 & 78 & 4395 \\
\hline 6385 & 74 & 72 & 71 & 90 & 74 & 4407 \\
\hline 6485 & 72 & 71 & 70 & 94 & 73 & 4415 \\
\hline 6485 & 73 & 72 & 72 & 97 & 72 & 4423 \\
\hline 6485 & 86 & $7 \overline{7}$ & 73 & 65 & 79 & 4461 \\
\hline 6485 & 93 & 76 & 68 & 44 & 89 & 4525 \\
\hline 6485 & 94 & 75 & 67 & 41 & 93 & 4596 \\
\hline 6485 & 82 & 72 & 67 & 61 & 88 & 4641 \\
\hline 6485 & 77 & 70 & 66 & 69 & 79 & 4666 \\
\hline 6485 & 75 & 70 & 67 & 76 & 76 & 4683 \\
\hline 6585 & 72 & 69 & 68 & 87 & 73 & 4691 \\
\hline 6585 & 74 & 71 & 69 & 85 & 73 & 4701 \\
\hline $\begin{array}{l}6585 \\
6 \quad 585\end{array}$ & $\begin{array}{l}88 \\
92\end{array}$ & 76 & 71 & 57 & 81 & 4745 \\
\hline $\begin{array}{l}6585 \\
6 \quad 585\end{array}$ & $\begin{array}{l}92 \\
80\end{array}$ & $\begin{array}{l}76 \\
78\end{array}$ & 69 & 47 & 90 & $\begin{array}{l}4808 \\
4867\end{array}$ \\
\hline $\begin{array}{l}6585 \\
6 \quad 585\end{array}$ & $\begin{array}{l}89 \\
79\end{array}$ & $\begin{array}{l}75 \\
77\end{array}$ & 68 & 50 & 90 & $\begin{array}{l}4867 \\
4907\end{array}$ \\
\hline $\begin{array}{l}6585 \\
6 \quad 585\end{array}$ & $\begin{array}{l}79 \\
74\end{array}$ & 73 & 70 & 74 & 84 & $\begin{array}{l}4902 \\
4017\end{array}$ \\
\hline $\begin{array}{l}6585 \\
6585\end{array}$ & $\begin{array}{l}74 \\
73\end{array}$ & 71 & 70 & 87 & 76 & $\begin{array}{l}4917 \\
4927\end{array}$ \\
\hline 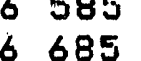 & $\begin{array}{l}73 \\
71\end{array}$ & 70 & 70 & $\begin{array}{l}90 \\
07\end{array}$ & 73 & $\begin{array}{l}4927 \\
4032\end{array}$ \\
\hline $6 \quad 685$ & 72 & 70 & $\begin{array}{l}07 \\
69\end{array}$ & $\begin{array}{l}73 \\
90\end{array}$ & 72 & $\begin{array}{l}4432 \\
4937\end{array}$ \\
\hline 6685 & 77 & 72 & 70 & 79 & 74 & 4954 \\
\hline 6685 & 81 & 75 & 72 & 74 & 79 & 4984 \\
\hline 6685 & 82 & 76 & 73 & 74 & 81 & 5019 \\
\hline 6685 & 78 & 73 & 71 & 79 & 80 & 5046 \\
\hline 6685 & 70 & 69 & 68 & 93 & 74 & 5052 \\
\hline 6685 & 69 & 68 & 67 & 93 & 69 & 5052 \\
\hline 6785 & 67 & 65 & 64 & 90 & 68 & 5052 \\
\hline 6785 & 70 & 67 & 66 & 87 & 68 & 5052 \\
\hline 6785 & 79 & 73 & 70 & 74 & 74 & 5073 \\
\hline 6785 & 81 & 70 & 64 & 56 & 80 & 3104 \\
\hline 6785 & 82 & 71 & 66 & 59 & 81 & 5139 \\
\hline 6785 & 74 & 69 & 66 & 76 & 78 & 5157 \\
\hline 6785 & 69 & 67 & 66 & 90 & 71 & 5160 \\
\hline 6785 & 68 & 67 & 66 & 93 & 68 & 5160 \\
\hline 6885 & 71 & 69 & 68 & 90 & 69 & 5161 \\
\hline 6885 & 72 & 70 & 69 & 90 & 71 & 5166 \\
\hline 6885 & 75 & 70 & 68 & 79 & 73 & 5179 \\
\hline 6885 & 80 & 71 & 67 & 65 & 77 & 5205 \\
\hline 6885 & 86 & 73 & 66 & 51 & 83 & 5249 \\
\hline 6885 & 83 & 72 & 66 & 57 & 84 & 5290 \\
\hline 6885 & 75 & 70 & 67 & 76 & 79 & 5311 \\
\hline 6885 & 68 & 67 & 66 & 93 & 71 & 5313 \\
\hline 6985 & 67 & 66 & 65 & 93 & 67 & 5313 \\
\hline 6985 & 69 & 67 & 66 & 90 & 68 & 5313 \\
\hline 6985 & 84 & 74 & 69 & 61 & 76 & 5344 \\
\hline 6985 & 89 & 75 & 69 & 52 & 86 & 5397 \\
\hline 6985 & 91 & 75 & 68 & 47 & 90 & 5459 \\
\hline
\end{tabular}




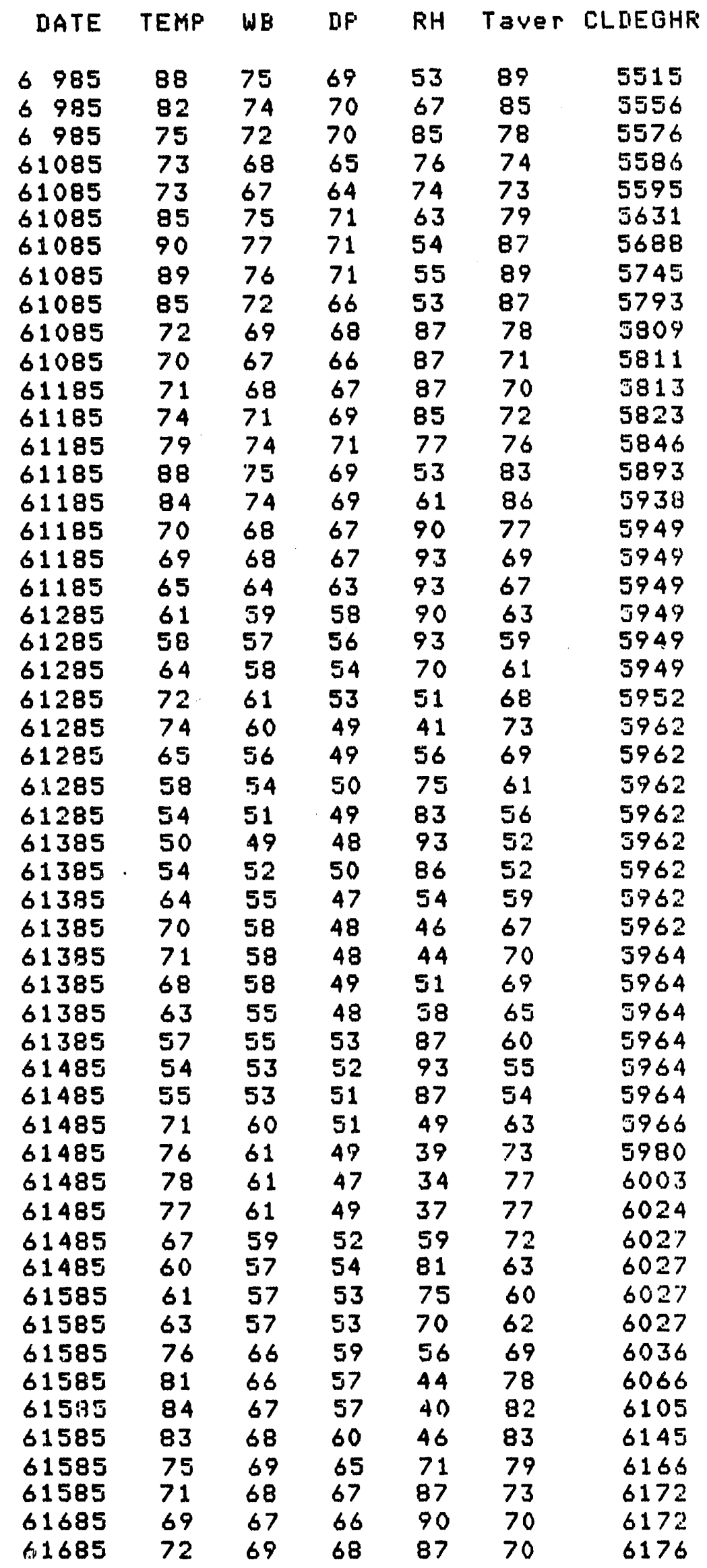




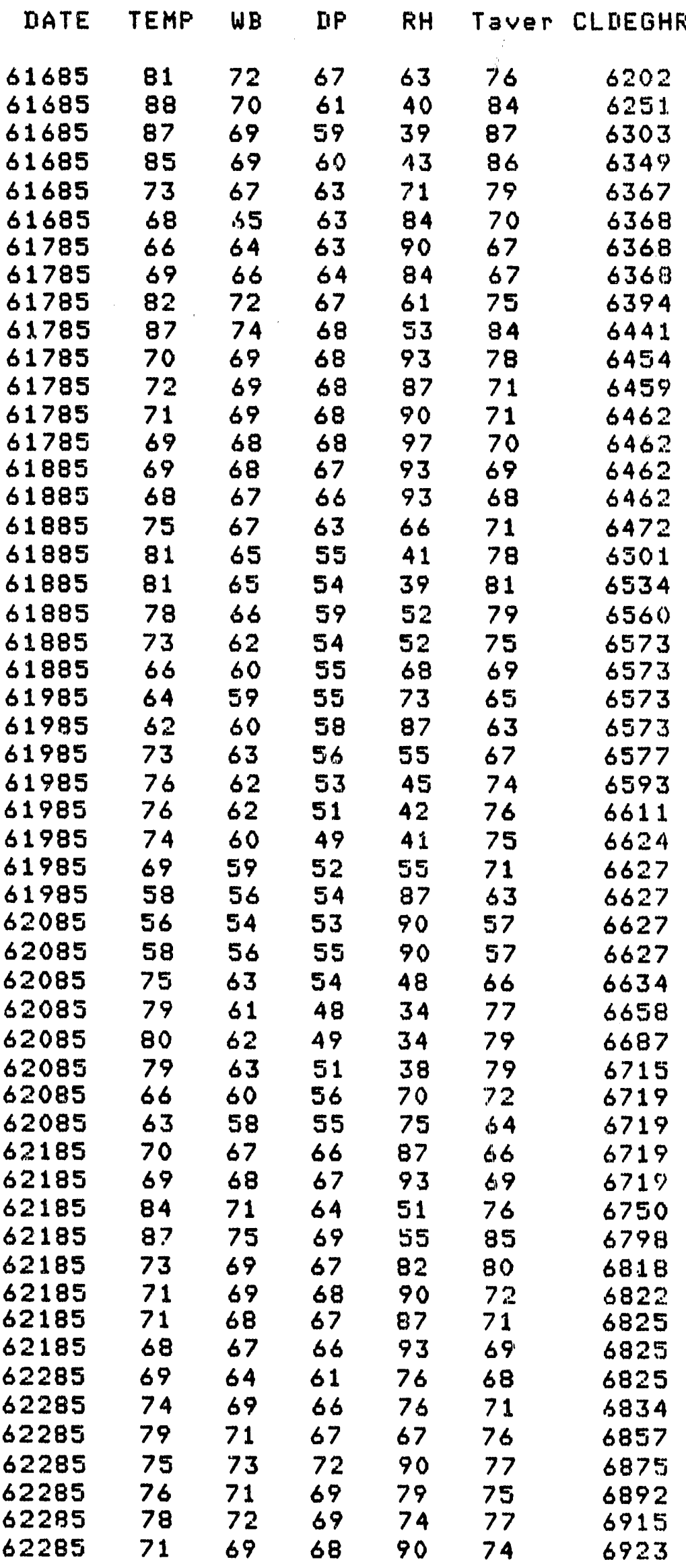




$\begin{array}{lllllll}\text { DATE } & \text { TElFP } & \text { WE } & \text { IIP } & \text { RH } & \text { T BVer } & \text { CLIEGHF } \\ 62285 & 69 & 67 & 66 & 90 & 70 & 6923 \\ 62385 & 68 & 66 & 65 & 90 & 68 & 6923 \\ 62385 & 71 & 68 & 67 & 87 & 69 & 6924 \\ 62385 & 82 & 73 & 69 & 65 & 76 & 6952 \\ 62385 & 87 & 75 & 69 & 55 & 84 & 6999 \\ 62385 & 90 & 74 & 67 & 47 & 88 & 7057 \\ 62385 & 87 & 74 & 68 & 53 & 88 & 7110 \\ 62385 & 80 & 73 & 69 & 69 & 83 & 7146 \\ 62385 & 73 & 70 & 69 & 87 & 76 & 7160 \\ 62485 & 72 & 70 & 69 & 90 & 72 & 7167 \\ 62485 & 74 & 72 & 71 & 90 & 73 & 7177 \\ 62485 & 87 & 75 & 70 & 57 & 80 & 7218 \\ 62485 & 92 & 75 & 67 & 44 & 89 & 7281 \\ 62485 & 85 & 75 & 71 & 63 & 88 & 7331 \\ 62485 & 86 & 75 & 70 & 59 & 85 & 7378 \\ 62485 & 78 & 70 & 65 & 64 & 82 & 7408 \\ 62485 & 73 & 70 & 68 & 84 & 75 & 7421 \\ 6085 & 70 & 67 & 66 & 87 & 71 & 7423 \\ 6085 & 69 & 68 & 67 & 93 & 69 & 7423 \\ 6085 & 84 & 71 & 64 & 51 & 76 & 7454 \\ 6085 & 87 & 75 & 69 & 55 & 85 & 7503 \\ 6085 & 73 & 69 & 67 & 82 & 80 & 7522 \\ 6085 & 71 & 69 & 68 & 90 & 72 & 7527 \\ 6085 & 71 & 68 & 67 & 87 & 71 & 7530 \\ 6085 & 68 & 67 & 66 & 93 & 69 & 7530 \\ 62685 & 66 & 65 & 64 & 93 & 67 & 7530 \\ 62685 & 68 & 67 & 66 & 93 & 67 & 7530 \\ 62685 & 79 & 72 & 68 & 69 & 73 & 7548 \\ 62685 & 88 & 75 & 69 & 53 & 83 & 7596 \\ 62685 & 90 & 74 & 67 & 47 & 89 & 7654 \\ 62685 & 85 & 75 & 70 & 61 & 87 & 7703 \\ 62685 & 79 & 73 & 70 & 74 & 82 & 7734 \\ 62685 & 76 & 73 & 71 & 85 & 77 & 7755 \\ 62785 & 73 & 71 & 70 & 90 & 74 & 7766 \\ 62785 & 74 & 72 & 71 & 90 & 73 & 7777 \\ 62785 & 86 & 73 & 66 & 51 & 80 & 7816 \\ 62785 & 89 & 74 & 66 & 47 & 87 & 7871 \\ 62785 & 86 & 72 & 64 & 48 & 87 & 7921 \\ 62785 & 85 & 71 & 63 & 48 & 85 & 7967 \\ 62785 & 78 & 70 & 66 & 74 & 81 & 7996 \\ 62785 & 76 & 72 & 70 & 82 & 77 & 8016 \\ 62885 & 72 & 68 & 65 & 79 & 74 & 8025 \\ 62885 & 70 & 67 & 66 & 87 & 71 & 8026 \\ 62885 & 70 & 67 & 66 & 87 & 70 & 8026 \\ 62885 & 76 & 71 & 68 & 76 & 73 & 8040 \\ 62885 & 75 & 67 & 62 & 64 & 75 & 8055 \\ 62885 & 75 & 67 & 63 & 66 & 75 & 8070 \\ 62885 & 72 & 68 & 65 & 79 & 73 & 8079 \\ 62985 & 69 & 65 & 63 & 81 & 70 & 8079 \\ 62985 & 68 & 65 & 63 & 84 & 68 & 8079 \\ 62985 & 79 & 68 & 62 & 56 & 77 & 8113\end{array}$




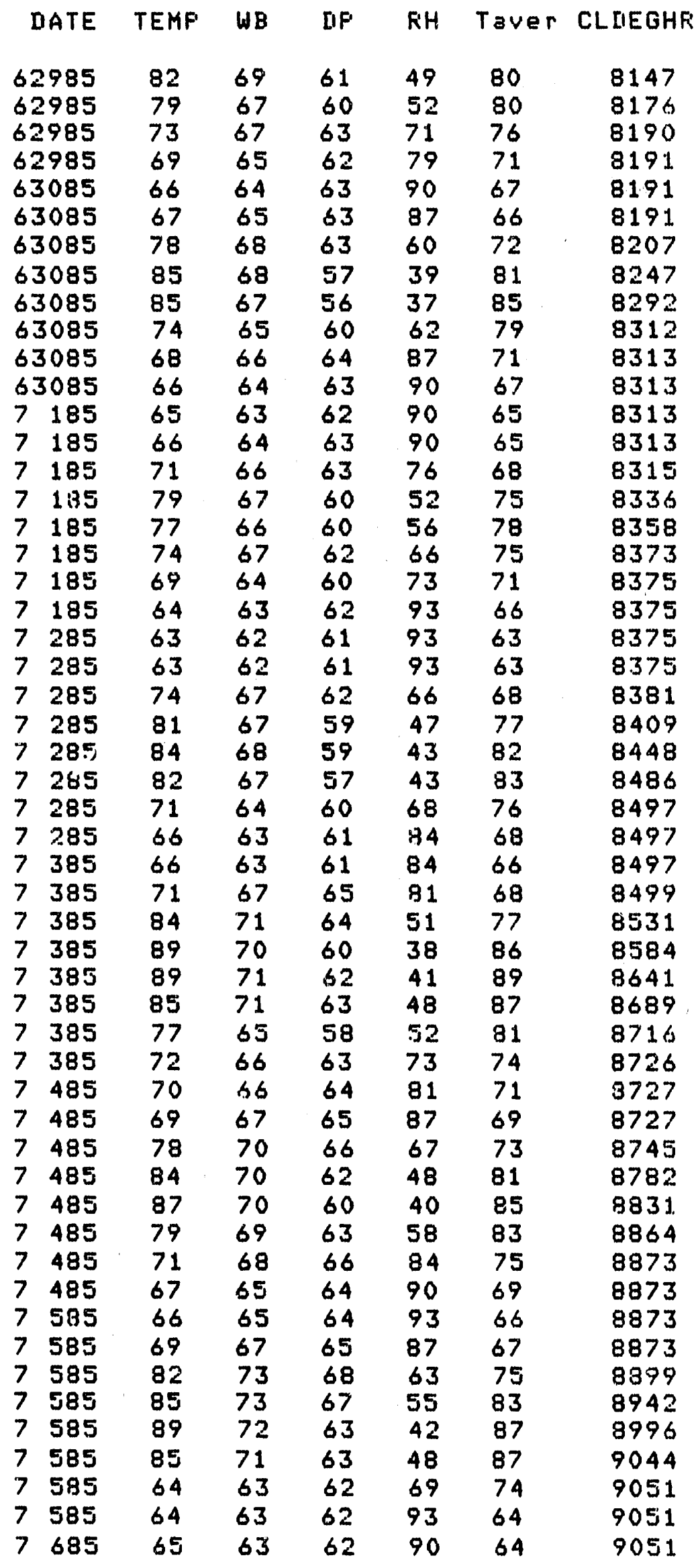




\begin{tabular}{|c|c|c|c|c|c|c|}
\hline DATE & TEMF' & WE & IIF' & $\mathrm{F} H \mathrm{H}$ & Taver & CLIIEGHK \\
\hline 7685 & 64 & 63 & 62 & 93 & 64 & 9051 \\
\hline 7685 & 74 & 67 & 62 & 60 & 69 & 9057 \\
\hline 7685 & 80 & 68 & 61 & 52 & 77 & 9082 \\
\hline 7685 & 82 & 68 & 60 & 47 & 81 & 9117 \\
\hline 7685 & 83 & 69 & 61 & 48 & 82 & 9155 \\
\hline 7685 & 77 & 69 & 64 & 64 & 80 & 9180 \\
\hline 7685 & 73 & 69 & 66 & 79 & 75 & 9192 \\
\hline 7785 & 67 & 65 & 64 & 90 & 70 & 9192 \\
\hline 7785 & 68 & 66 & 65 & 90 & 67 & 9192 \\
\hline 7785 & 82 & 70 & 63 & 53 & 75 & 9218 \\
\hline 7785 & 85 & 69 & 60 & 43 & 83 & 9261 \\
\hline 7785 & 87 & 69 & 59 & 39 & 86 & 9310 \\
\hline 7785 & 86 & 69 & 60 & 42 & 86 & 9359 \\
\hline 7785 & 79 & 68 & 62 & 56 & 82 & 9391 \\
\hline 7785 & 70 & 67 & 65 & 84 & 74 & 9398 \\
\hline 7885 & 68 & 66 & 64 & 87 & 69 & 9398 \\
\hline 7885 & 71 & 67 & 64 & 79 & 69 & 9399 \\
\hline 7885 & 85 & 73 & 67 & 55 & 78 & 9434 \\
\hline 7885 & 89 & 74 & 66 & 47 & 87 & 9488 \\
\hline 7885 & 89 & 73 & 65 & 45 & 89 & 9545 \\
\hline 7885 & 88 & 73 & 66 & 48 & 88 & 9600 \\
\hline 7885 & 79 & 72 & 68 & 69 & 83 & 9633 \\
\hline 7885 & 76 & 70 & 67 & 74 & 77 & 9654 \\
\hline 7985 & 74 & 69 & 67 & 79 & 75 & 9667 \\
\hline 7985 & 77 & 70 & 67 & 71 & 75 & 9686 \\
\hline 7985 & 84 & 74 & 69 & 61 & 80 & 9723 \\
\hline 7985 & 92 & 76 & 69 & 47 & 88 & 9783 \\
\hline 7985 & 93 & 75 & 67 & 43 & 92 & 9851 \\
\hline 7985 & 90 & 75 & 68 & 48 & 91 & 9913 \\
\hline 7985 & 84 & 74 & 70 & 63 & 87 & 9960 \\
\hline 7985 & 79 & 74 & 71 & 77 & 81 & 9990 \\
\hline 71085 & 75 & 72 & 70 & 85 & 77 & 10008 \\
\hline 71085 & 76 & 73 & 71 & 85 & 75 & 10026 \\
\hline 71085 & 88 & 76 & 70 & 55 & 82 & 10071 \\
\hline 71085 & 95 & 75 & 66 & 39 & 91 & 10140 \\
\hline 71085 & 95 & 76 & 68 & 41 & 95 & 10215 \\
\hline 71085 & 77 & 69 & 65 & 67 & 86 & 10250 \\
\hline 71085 & 73 & 71 & 70 & 90 & 75 & 10262 \\
\hline 71085 & 72 & 70 & 69 & 90 & 72 & 10269 \\
\hline 71185 & 71 & 70 & 69 & 93 & 71 & 10272 \\
\hline 71185 & 71 & 70 & 69 & 93 & 71 & 10275 \\
\hline 71185 & 78 & 73 & 71 & 79 & 74 & 10294 \\
\hline 71185 & 89 & 74 & 66 & 47 & 83 & 10343 \\
\hline 71185 & 91 & 75 & 67 & 45 & 90 & 10404 \\
\hline 71185 & 87 & 71 & 63 & 45 & 89 & 10458 \\
\hline 71185 & 82 & 73 & 68 & 63 & 84 & 10498 \\
\hline 71185 & 77 & 72 & 69 & 76 & 79 & 10523 \\
\hline 71285 & 73 & 70 & 69 & 87 & 75 & 10535 \\
\hline 71285 & 73 & 71 & 70 & 90 & 73 & 10544 \\
\hline 71285 & 85 & 76 & 72 & 65 & 79 & 10580 \\
\hline 71285 & 93 & 76 & 69 & 46 & 89 & 10643 \\
\hline 71285 & 89 & 73 & 65 & 45 & 91 & 10703 \\
\hline 71285 & 88 & 74 & 67 & 50 & 88 & 10758 \\
\hline
\end{tabular}




$\begin{array}{lllllll}\text { IAATE } & \text { TENF } & \text { WE } & \text { UF } & \text { RH } & \text { TaVER } & \text { CLLEGHF } \\ 71285 & 80 & 73 & 69 & 69 & 84 & 10794 \\ 71285 & 80 & 73 & 69 & 69 & 80 & 10824 \\ 71385 & 78 & 67 & 61 & 56 & 79 & 10849 \\ 71385 & 76 & 73 & 71 & 85 & 77 & 10869 \\ 71385 & 81 & 75 & 72 & 74 & 78 & 10898 \\ 71385 & 91 & 77 & 71 & 52 & 86 & 10953 \\ 71385 & 94 & 77 & 70 & 46 & 92 & 11023 \\ 71385 & 88 & 76 & 71 & 57 & 91 & 11082 \\ 71385 & 83 & 75 & 72 & 70 & 85 & 11124 \\ 71385 & 77 & 72 & 70 & 79 & 80 & 11150 \\ 71485 & 76 & 72 & 70 & 82 & 76 & 11169 \\ 71485 & 78 & 73 & 71 & 79 & 77 & 11191 \\ 71485 & 89 & 76 & 71 & 55 & 83 & 11240 \\ 71485 & 96 & 77 & 68 & 40 & 92 & 11313 \\ 71485 & 97 & 76 & 67 & 38 & 96 & 11393 \\ 71485 & 93 & 74 & 64 & 38 & 95 & 11465 \\ 71485 & 85 & 75 & 71 & 63 & 89 & 11516 \\ 71485 & 80 & 74 & 71 & 74 & 82 & 11550 \\ 71585 & 79 & 73 & 70 & 74 & 79 & 11577 \\ 71585 & 81 & 74 & 71 & 72 & 80 & 11609 \\ 71585 & 89 & 76 & 71 & 55 & 85 & 11660 \\ 71585 & 93 & 77 & 70 & 47 & 91 & 11726 \\ 71585 & 88 & 76 & 71 & 57 & 90 & 11784 \\ 71585 & 84 & 74 & 70 & 63 & 86 & 11829 \\ 71585 & 79 & 72 & 69 & 72 & 81 & 11859 \\ 71585 & 77 & 71 & 68 & 74 & 78 & 11882 \\ 71685 & 75 & 70 & 68 & 79 & 76 & 11898 \\ 71685 & 75 & 72 & 70 & 85 & 75 & 11913 \\ 71685 & 84 & 74 & 70 & 63 & 79 & 11949 \\ 71685 & 87 & 72 & 65 & 48 & 85 & 11997 \\ 71685 & 90 & 70 & 59 & 35 & 88 & 12055 \\ 71685 & 86 & 68 & 58 & 39 & 88 & 12106 \\ 71685 & 75 & 65 & 59 & 58 & 80 & 12129 \\ 71685 & 69 & 62 & 57 & 66 & 72 & 12132 \\ 71785 & 65 & 60 & 57 & 76 & 67 & 12132 \\ 71785 & 65 & 61 & 58 & 78 & 65 & 12132 \\ 71785 & 80 & 66 & 57 & 45 & 72 & 12151 \\ 71785 & 86 & 69 & 59 & 40 & 83 & 12195 \\ 71785 & 89 & 68 & 56 & 33 & 87 & 12249 \\ 71785 & 86 & 68 & 58 & 39 & 87 & 12300 \\ 71785 & 74 & 64 & 58 & 58 & 80 & 12321 \\ 71785 & 70 & 63 & 58 & 66 & 72 & 12324 \\ 71885 & 68 & 62 & 58 & 71 & 69 & 12324 \\ 71885 & 67 & 63 & 61 & 81 & 67 & 12324 \\ 71885 & 83 & 72 & 66 & 57 & 75 & 12351 \\ 71885 & 92 & 76 & 69 & 47 & 87 & 12410 \\ 71885 & 95 & 74 & 64 & 36 & 93 & 12483 \\ 71885 & 79 & 75 & 73 & 82 & 83 & 12576 \\ 71985 & 75 & 73 & 72 & 90 & 77 & 12594 \\ 71985 & 75 & 71 & 70 & 90 & 74 & 12604 \\ 71 & 72 & 71 & 87 & 74 & 12618 \\ 74 & 68 & 55 & 80 & 12657\end{array}$




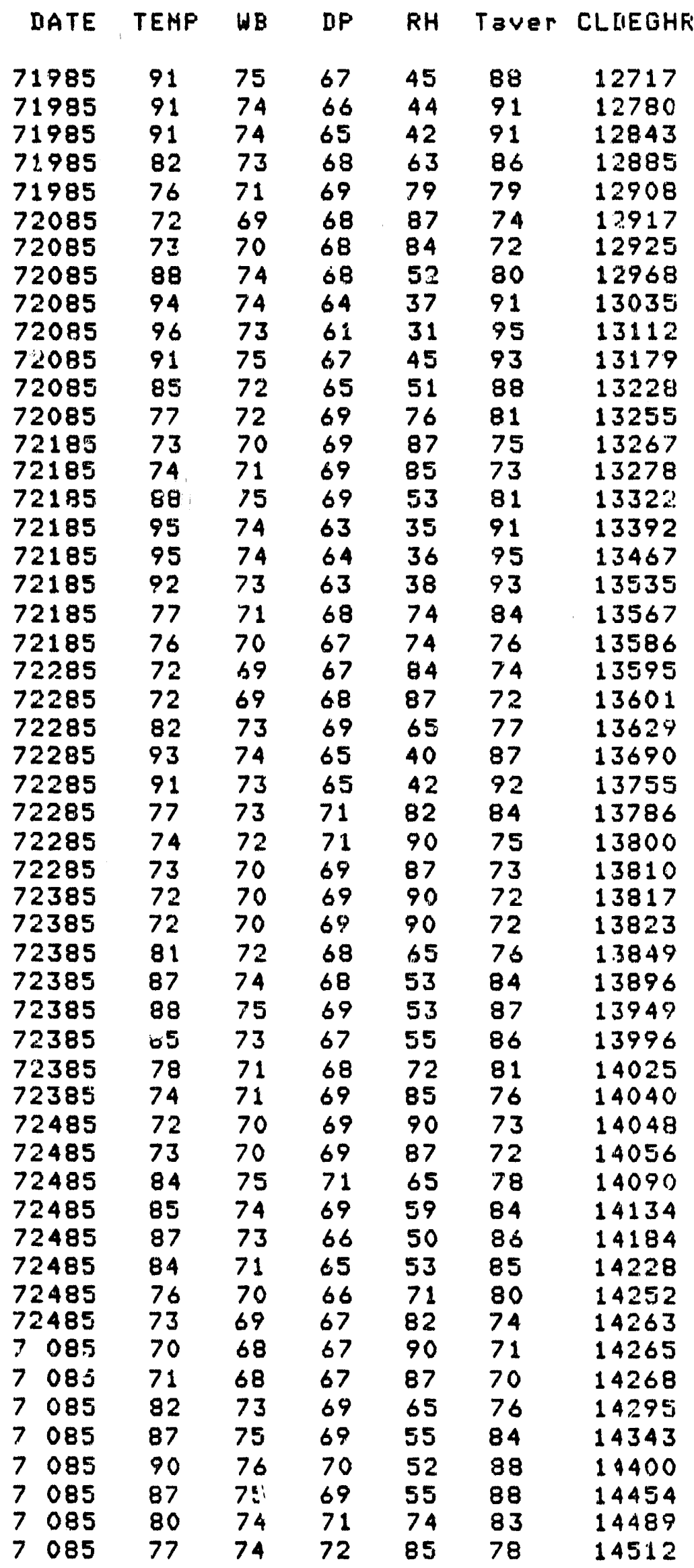




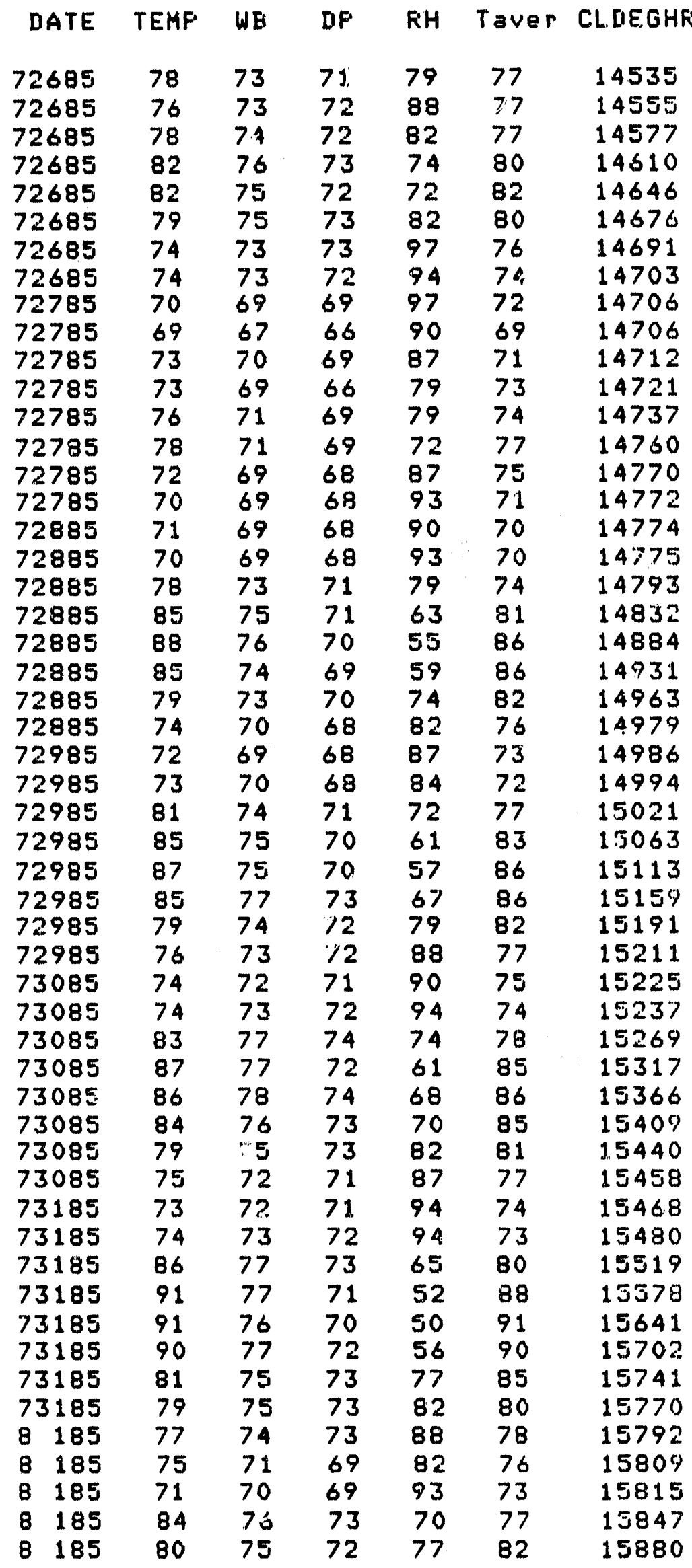




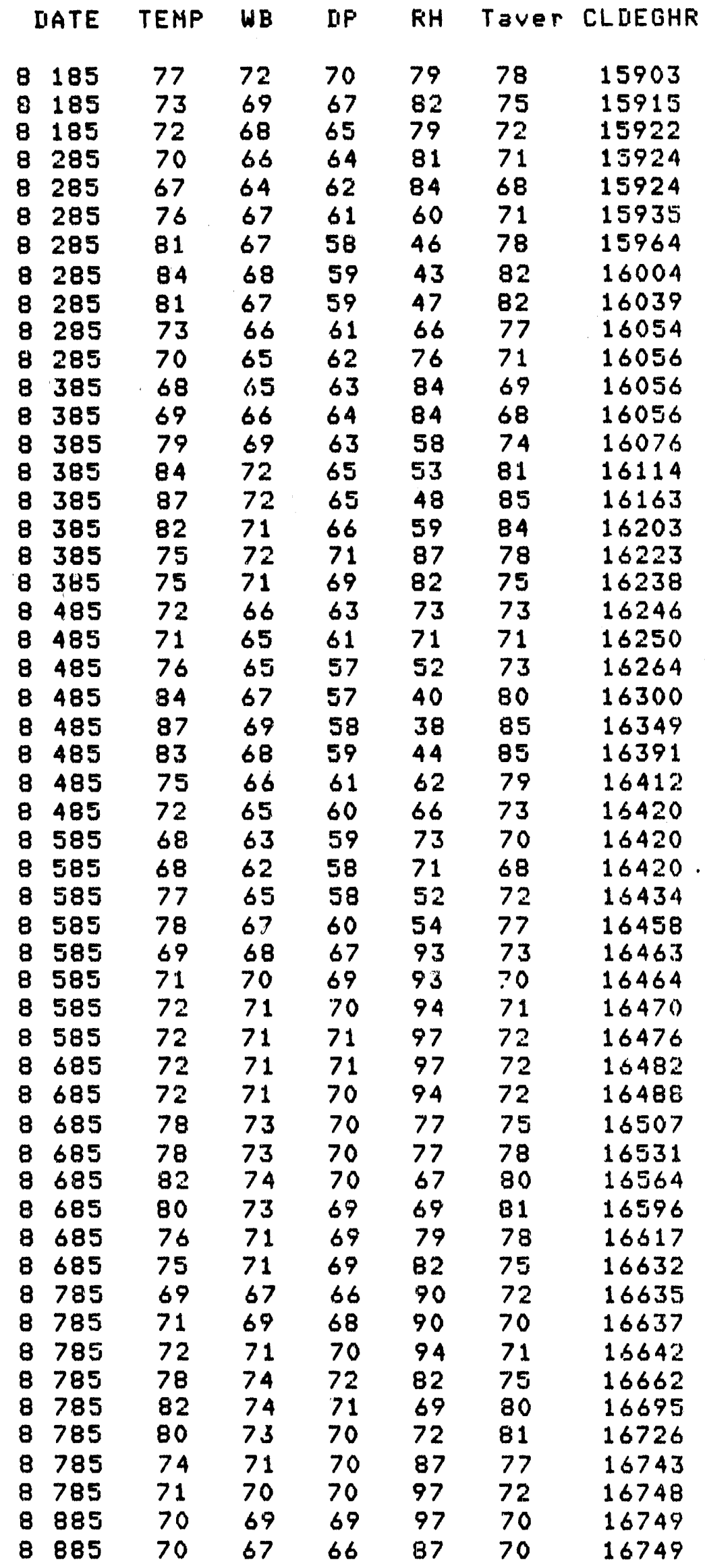




\begin{tabular}{|c|c|c|c|c|c|c|}
\hline DATE & TEMF & $W B$ & IIP & FiH & Taver & CLDEGHR \\
\hline 8885 & 75 & 72 & 70 & 85 & 72 & 16760 \\
\hline 8885 & 81 & 73 & 69 & 67 & 78 & 16788 \\
\hline 8885 & 86 & 74 & 69 & 57 & 83 & 16833 \\
\hline $\begin{array}{ll}8 & 885 \\
8 & 885\end{array}$ & $\begin{array}{l}84 \\
77\end{array}$ & $\begin{array}{l}74 \\
72\end{array}$ & $\begin{array}{l}69 \\
70\end{array}$ & $\begin{array}{l}61 \\
79\end{array}$ & $\begin{array}{l}85 \\
80\end{array}$ & $\begin{array}{l}16876 \\
16902\end{array}$ \\
\hline $\begin{array}{l}885 \\
8\end{array}$ & 74 & 71 & 70 & 87 & 75 & $\begin{array}{l}16902 \\
16917\end{array}$ \\
\hline 8985 & 70 & 69 & 69 & 97 & 72 & 16920 \\
\hline 8485 & 71 & 70 & 69 & 93 & 70 & 16922 \\
\hline 8985 & 83 & 75 & 72 & 70 & 77 & 16952 \\
\hline 8985 & 89 & 74 & 67 & 48 & 86 & 17004 \\
\hline 8985 & 91 & 75 & 67 & 45 & 90 & 17066 \\
\hline $\begin{array}{ll}8 & 985 \\
8 & 985\end{array}$ & $\begin{array}{l}86 \\
79\end{array}$ & $\begin{array}{l}733 \\
71\end{array}$ & $\begin{array}{l}66 \\
67\end{array}$ & $\begin{array}{l}51 \\
67\end{array}$ & $\begin{array}{l}88 \\
82\end{array}$ & $\begin{array}{l}17118 \\
17150\end{array}$ \\
\hline 8985 & 75 & 71 & 69 & 82 & 77 & 17168 \\
\hline 81085 & 72 & 70 & 69 & 90 & 73 & 17176 \\
\hline 81085 & 71 & 70 & 69 & 93 & 71 & 17180 \\
\hline 81085 & 84 & 75 & 71 & 65 & 77 & 17212 \\
\hline 81085 & 92 & 75 & 67 & 44 & 88 & 17272 \\
\hline 81085 & 93 & 71 & 60 & 33 & 92 & 17340 \\
\hline 81085 & 84 & 74 & 69 & 61 & 88 & 17389 \\
\hline 81085 & 81 & 75 & 73 & 77 & 82 & 17424 \\
\hline 81085 & 79 & 75 & 73 & 82 & 80 & 17453 \\
\hline 81185 & 76 & 74 & 73 & 91 & 77 & 17473 \\
\hline 81185 & 74 & 73 & 73 & 97 & 75 & 17487 \\
\hline 81185 & 84 & 76 & 72 & 67 & 79 & 17521 \\
\hline 81185 & 91 & 76 & 70 & 50 & 87 & 17579 \\
\hline 81185 & 90 & 76 & 70 & 52 & 90 & 17640 \\
\hline 81185 & 85 & 76 & 72 & 65 & 87 & 17688 \\
\hline 81185 & 81 & 75 & 72 & 74 & 83 & 17724 \\
\hline 81185 & 77 & 74 & 73 & 88 & 79 & 17748 \\
\hline 81285 & 73 & 72 & 71 & 94 & 75 & 17760 \\
\hline 81285 & 74 & 72 & 71 & 90 & 73 & 17772 \\
\hline 81285 & 86 & 76 & 71 & 61 & 80 & 17811 \\
\hline 81285 & 90 & 76 & 70 & 52 & 88 & 17868 \\
\hline 81285 & 69 & 77 & 68 & 40 & 79 & 17882 \\
\hline 81285 & 89 & 75 & 69 & 52 & 79 & 17924 \\
\hline 81285 & 80 & 75 & 72 & 77 & 84 & 17961 \\
\hline 81285 & 76 & 73 & 72 & 88 & 78 & 17982 \\
\hline 81385 & 76 & 73 & 71 & 85 & 76 & 18000 \\
\hline 81385 & 75 & 72 & 71 & 87 & 75 & 18015 \\
\hline 81385 & 87 & 76 & 71 & 59 & 81 & 18057 \\
\hline 81385 & 90 & 74 & 67 & 47 & 88 & 18115 \\
\hline 81385 & 95 & 76 & 67 & 40 & 92 & 18186 \\
\hline 81385 & 89 & 75 & 68 & 50 & 92 & 18248 \\
\hline 81385 & 81 & 73 & 69 & 67 & 85 & 18287 \\
\hline 81385 & 76 & 72 & 70 & 82 & 78 & 18309 \\
\hline 81485 & 76 & 72 & 70 & 82 & 76 & 18327 \\
\hline 81485 & 75 & 71 & 69 & 82 & 75 & 18342 \\
\hline 81485 & 87 & 74 & 68 & 53 & 81 & 18384 \\
\hline 81485 & 93 & 75 & 66 & 41 & 90 & 18449 \\
\hline 81485 & 94 & 74 & 64 & 37 & 93 & 18520 \\
\hline 81485 & 87 & 73 & 66 & 50 & 90 & 18576 \\
\hline 81485 & 81 & 72 & 68 & 65 & 84 & 18614 \\
\hline
\end{tabular}




$\begin{array}{lllllll}\text { DATE } & \text { TEMF } & \text { WB } & \text { DF } & \text { RH } & \text { TaVer } & \text { CLIIEGHR } \\ 81485 & 80 & 73 & 70 & 72 & 80 & 18645 \\ 81585 & 77 & 72 & 70 & 79 & 78 & 18668 \\ 81585 & 75 & 72 & 70 & 85 & 76 & 18684 \\ 81585 & 78 & 74 & 72 & 82 & 76 & 18706 \\ 81585 & 89 & 75 & 68 & 50 & 83 & 18755 \\ 81585 & 88 & 74 & 68 & 52 & 88 & 18810 \\ 81585 & 82 & 73 & 68 & 63 & 85 & 18850 \\ 81585 & 76 & 72 & 70 & 82 & 79 & 18873 \\ 81585 & 75 & 71 & 69 & 82 & 75 & 18888 \\ 81685 & 72 & 70 & 69 & 90 & 73 & 18897 \\ 81685 & 72 & 71 & 70 & 94 & 72 & 18903 \\ 81685 & 73 & 72 & 71 & 94 & 72 & 18911 \\ 81685 & 72 & 71 & 70 & 94 & 72 & 18918 \\ 81685 & 72 & 71 & 70 & 94 & 72 & 18924 \\ 81685 & 71 & 70 & 69 & 93 & 71 & 18927 \\ 81685 & 72 & 71 & 70 & 94 & 71 & 18933 \\ 81685 & 72 & 70 & 69 & 90 & 72 & 18939 \\ 81785 & 71 & 70 & 69 & 93 & 71 & 18942 \\ 81785 & 71 & 70 & 70 & 97 & 71 & 18945 \\ 81785 & 73 & 71 & 70 & 90 & 72 & 18953 \\ 81785 & 81 & 74 & 70 & 69 & 77 & 18980 \\ 81785 & 82 & 73 & 69 & 65 & 81 & 19015 \\ 81785 & 83 & 74 & 70 & 65 & 82 & 19053 \\ 81785 & 77 & 71 & 68 & 74 & 80 & 19079 \\ 81785 & 73 & 71 & 70 & 90 & 75 & 19091 \\ 81885 & 71 & 70 & 69 & 93 & 72 & 19095 \\ 81885 & 69 & 68 & 68 & 97 & 70 & 19095 \\ 81885 & 81 & 74 & 70 & 69 & 75 & 19119 \\ 81885 & 87 & 75 & 70 & 57 & 84 & 19166 \\ 81885 & 88 & 74 & 68 & 52 & 87 & 19219 \\ 81885 & 84 & 73 & 68 & 59 & 86 & 19264 \\ 81885 & 76 & 72 & 70 & 82 & 80 & 19288 \\ 81885 & 73 & 71 & 70 & 90 & 74 & 19299 \\ 81985 & 73 & 71 & 70 & 90 & 73 & 19308 \\ 81985 & 71 & 70 & 69 & 93 & 72 & 19313 \\ 81985 & 82 & 76 & 74 & 77 & 76 & 19341 \\ 81985 & 91 & 77 & 71 & 52 & 86 & 19397 \\ 81985 & 90 & 76 & 69 & 50 & 90 & 19458 \\ 81985 & 80 & 74 & 71 & 74 & 85 & 19495 \\ 81985 & 77 & 72 & 69 & 76 & 78 & 19518 \\ 81985 & 74 & 70 & 68 & 82 & 75 & 19533 \\ 82085 & 72 & 69 & 68 & 87 & 73 & 19540 \\ 82085 & 70 & 67 & 65 & 84 & 71 & 19542 \\ 82085 & 69 & 67 & 66 & 90 & 69 & 19542 \\ 82085 & 79 & 72 & 69 & 72 & 74 & 19561 \\ 82085 & 78 & 72 & 69 & 74 & 78 & 19586 \\ 82085 & 74 & 69 & 66 & 76 & 76 & 19601 \\ 82085 & 69 & 67 & 65 & 87 & 71 & 19603 \\ 82085 & 67 & 65 & 64 & 90 & 68 & 19603 \\ 82185 & 66 & 64 & 63 & 90 & 66 & 19603 \\ 82185 & 64 & 63 & 62 & 93 & 65 & 19603 \\ 82185 & 73 & 68 & 65 & 76 & 68 & 19608 \\ 82185 & 79 & 68 & 62 & 56 & 76 & 19630\end{array}$




$\begin{array}{lllllll}\text { IIATE } & \text { TEMP } & \text { WB } & \text { DF } & \text { RH } & \text { T BVER CLIIEGHF } \\ 82185 & 81 & 69 & 62 & 53 & 80 & 19662 \\ 82185 & 76 & 66 & 60 & 58 & 78 & 19683 \\ 82185 & 70 & 65 & 61 & 73 & 73 & 19688 \\ 82185 & 67 & 64 & 62 & 84 & 68 & 19688 \\ 82285 & 64 & 63 & 62 & 93 & 65 & 19688 \\ 82285 & 62 & 61 & 60 & 93 & 63 & 19688 \\ 82285 & 77 & 66 & 59 & 54 & 69 & 19698 \\ 82285 & 82 & 68 & 60 & 47 & 79 & 19731 \\ 82285 & 82 & 68 & 60 & 47 & 82 & 19767 \\ 82285 & 77 & 68 & 62 & 60 & 79 & 19791 \\ 82285 & 74 & 67 & 62 & 66 & 75 & 19806 \\ 82285 & 70 & 66 & 63 & 79 & 72 & 19809 \\ 82385 & 67 & 65 & 64 & 90 & 68 & 19809 \\ 82385 & 66 & 64 & 63 & 90 & 66 & 19809 \\ 82385 & 70 & 66 & 64 & 81 & 68 & 19809 \\ 82385 & 73 & 69 & 66 & 79 & 71 & 19815 \\ 82385 & 74 & 71 & 70 & 87 & 73 & 19827 \\ 82385 & 77 & 72 & 70 & 79 & 75 & 19845 \\ 82385 & 76 & 73 & 71 & 85 & 76 & 19864 \\ 82385 & 75 & 72 & 71 & 87 & 75 & 19880 \\ 82485 & 73 & 72 & 71 & 94 & 74 & 19890 \\ 82485 & 74 & 72 & 71 & 90 & 73 & 19902 \\ 82485 & 70 & 69 & 68 & 93 & 72 & 19905 \\ 82485 & 73 & 70 & 69 & 87 & 71 & 19911 \\ 82485 & 73 & 71 & 70 & 90 & 73 & 19920 \\ 82485 & 72 & 70 & 69 & 90 & 72 & 19927 \\ 82485 & 71 & 69 & 68 & 90 & 71 & 19931 \\ 82485 & 70 & 69 & 68 & 93 & 70 & 19932 \\ 8085 & 70 & 69 & 68 & 93 & 70 & 19932 \\ 8085 & 70 & 69 & 68 & 93 & 70 & 19932 \\ 80855 & 73 & 70 & 69 & 87 & 71 & 19938 \\ 8085 & 79 & 72 & 69 & 72 & 76 & 19961 \\ 8085 & 76 & 71 & 68 & 76 & 77 & 19981 \\ 8085 & 74 & 69 & 67 & 79 & 75 & 19995 \\ 8085 & 68 & 66 & 64 & 87 & 71 & 19996 \\ 8085 & 64 & 63 & 62 & 93 & 66 & 19996 \\ 82685 & 63 & 62 & 61 & 93 & 63 & 19996 \\ 82685 & 61 & 60 & 60 & 97 & 62 & 19996 \\ 82685 & 73 & 67 & 64 & 74 & 67 & 20001 \\ 82685 & 79 & 67 & 60 & 52 & 76 & 20023 \\ 82685 & 82 & 68 & 60 & 47 & 80 & 20057 \\ 82685 & 76 & 67 & 62 & 62 & 79 & 20079 \\ 82685 & 71 & 66 & 63 & 76 & 73 & 20086 \\ 82685 & 67 & 65 & 63 & 87 & 69 & 20086 \\ 82785 & 64 & 63 & 63 & 97 & 65 & 20086 \\ 82785 & 62 & 61 & 60 & 93 & 63 & 20086 \\ 82785 & 74 & 69 & 66 & 76 & 68 & 20092 \\ 82785 & 82 & 70 & 64 & 55 & 78 & 20122 \\ 82785 & 82 & 69 & 61 & 49 & 82 & 20158 \\ 82785 & 78 & 69 & 64 & 62 & 80 & 20185 \\ 82885 & 72 & 67 & 64 & 76 & 75 & 20196 \\ 84 & 63 & 63 & 97 & 65 & 20196\end{array}$




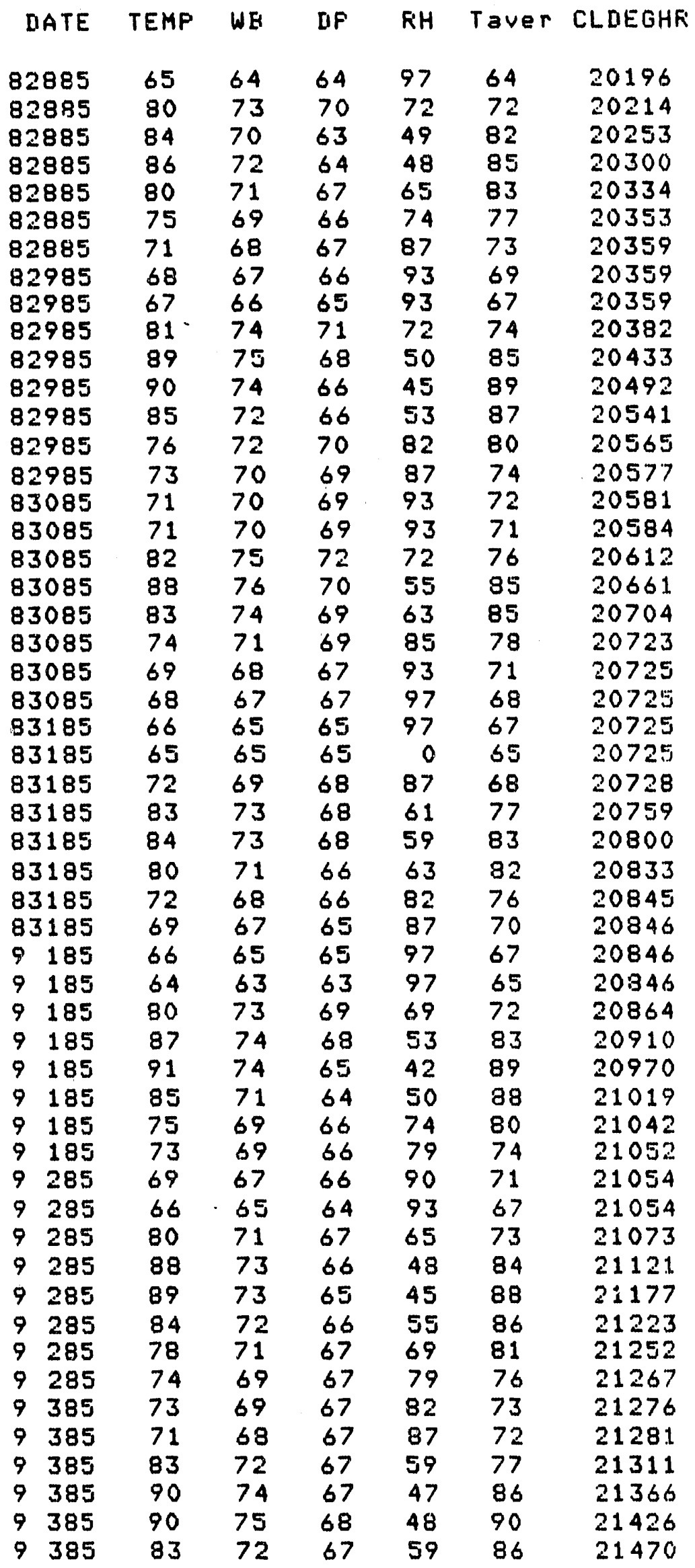




\begin{tabular}{|c|c|c|c|c|c|c|}
\hline DATE & TEMF' & $11 \mathrm{~B}$ & IIF' & FiH & Taver & CLIIEGHF \\
\hline 9385 & 76 & 70 & 67 & 74 & 79 & 21493 \\
\hline 9385 & 73 & 69 & 67 & 82 & 74 & 21504 \\
\hline 9485 & 71 & 68 & 67 & 87 & 72 & 21509 \\
\hline 9485 & 70 & 68 & 67 & 90 & 70 & 21510 \\
\hline 9485 & 83 & 74 & 70 & 65 & 76 & 21539 \\
\hline 9485 & 88 & 74 & 67 & 50 & 85 & 21589 \\
\hline 9485 & 89 & 74 & 67 & 48 & 88 & 21645 \\
\hline 9485 & 83 & 72 & 67 & 59 & 86 & 21689 \\
\hline 9485 & 75 & 70 & 68 & 79 & 79 & 21710 \\
\hline 9485 & 75 & 70 & 68 & 79 & 75 & 21725 \\
\hline 9585 & 73 & 70 & 68 & 84 & 74 & 21735 \\
\hline 9585 & 75 & 71 & 69 & 82 & 74 & 21749 \\
\hline 9585 & 79 & 74 & 71 & 77 & 77 & 21773 \\
\hline 9585 & 79 & 74 & 72 & 79 & 79 & 21800 \\
\hline 9585 & 79 & 75 & 73 & 82 & 79 & 21827 \\
\hline 9585 & 79 & 75 & 73 & 82 & 79 & 21854 \\
\hline 9585 & 76 & 74 & 73 & 91 & 77 & 21874 \\
\hline 9585 & 76 & 74 & 73 & 91 & 76 & 21892 \\
\hline 9685 & 74 & 73 & 72 & 94 & 75 & 21906 \\
\hline 9685 & 73 & 71 & 70 & 90 & 73 & 21915 \\
\hline 9685 & 84 & 74 & 70 & 63 & 78 & 21949 \\
\hline 9685 & 89 & 75 & 69 & 52 & 86 & 22002 \\
\hline 9685 & 91 & 75 & 68 & 47 & 90 & 22064 \\
\hline 9685 & 84 & 73 & 68 & 59 & 87 & 22111 \\
\hline 9685 & 76 & 72 & 70 & 82 & 80 & 22135 \\
\hline 9685 & 74 & 71 & 70 & 87 & 75 & 22149 \\
\hline 9785 & 72 & 70 & 69 & 90 & 73 & 22156 \\
\hline 9785 & 70 & 69 & 68 & 93 & 71 & 22158 \\
\hline 9785 & 85 & 77 & 73 & 67 & 77 & 22191 \\
\hline 9785 & 89 & 76 & 70 & 54 & 87 & 22245 \\
\hline 9785 & 90 & 74 & 37 & 47 & 89 & 22305 \\
\hline 9785 & 86 & 76 & 71 & 61 & 88 & 22356 \\
\hline 9785 & 82 & 75 & 72 & 77 & 83 & 22390 \\
\hline 9785 & 76 & 73 & 71 & 85 & 78 & 22411 \\
\hline 9835 & 72 & 71 & 70 & 94 & 74 & 22420 \\
\hline 9885 & 71 & 70 & 69 & 93 & 71 & 22424 \\
\hline 9885 & 85 & 77 & 73 & 67 & 78 & 22458 \\
\hline 9885 & 89 & 75 & 69 & 52 & 87 & 22512 \\
\hline $\begin{array}{l}9885 \\
9 \\
9885\end{array}$ & $\begin{array}{l}92 \\
87\end{array}$ & $\begin{array}{l}77 \\
75\end{array}$ & $\begin{array}{l}70 \\
69\end{array}$ & $\begin{array}{r}49 \\
55\end{array}$ & $\begin{array}{l}90 \\
89\end{array}$ & $\begin{array}{l}22576 \\
22631\end{array}$ \\
\hline $\begin{array}{ll}9 & 885 \\
9 & 885\end{array}$ & $\begin{array}{l}87 \\
76\end{array}$ & 71 & $\begin{array}{l}69 \\
68\end{array}$ & $\begin{array}{l}55 \\
76\end{array}$ & $\begin{array}{l}89 \\
81\end{array}$ & $\begin{array}{l}22631 \\
22657\end{array}$ \\
\hline 9885 & 74 & 70 & 68 & 82 & 75 & 22671 \\
\hline 9985 & 71 & 69 & 68 & 90 & 72 & 22676 \\
\hline 9985 & 70 & 69 & 68 & 93 & 70 & 22677 \\
\hline 9985 & 82 & 73 & 69 & 65 & 76 & 22704 \\
\hline 9985 & 86 & 74 & 69 & 57 & 84 & 22749 \\
\hline 9985 & 89 & 75 & 68 & 50 & 87 & 22803 \\
\hline 9985 & 84 & 74 & 69 & 61 & 86 & 22849 \\
\hline 9985 & 78 & 73 & 70 & 77 & 81 & 22878 \\
\hline 9985 & 77 & 72 & 70 & 79 & 77 & 22899 \\
\hline 91085 & 72 & 70 & 69 & 90 & 74 & 22909 \\
\hline 91085 & 72 & 70 & 69 & 90 & 72 & 22915 \\
\hline 91085 & 84 & 76 & 72 & 67 & 78 & 22948 \\
\hline
\end{tabular}




$\begin{array}{lllllll}\text { DATE } & \text { TEMF } & \text { WE } & \text { IIF } & \text { FH } & \text { T aVer } & \text { CLIIEGHF } \\ 91085 & 90 & 76 & 70 & 52 & 87 & 23004 \\ 91085 & 90 & 76 & 70 & 52 & 90 & 23064 \\ 91085 & 74 & 72 & 71 & 90 & 82 & 23088 \\ 91085 & 74 & 72 & 71 & 90 & 74 & 23100 \\ 91085 & 72 & 70 & 69 & 90 & 73 & 23167 \\ 91185 & 69 & 67 & 66 & 90 & 70 & 23108 \\ 91185 & 67 & 66 & 65 & 93 & 68 & 23108 \\ 91185 & 73 & 70 & 68 & 84 & 70 & 23112 \\ 91185 & 77 & 71 & 68 & 74 & 75 & 23130 \\ 91185 & 81 & 72 & 68 & 65 & 79 & 23160 \\ 91185 & 77 & 69 & 64 & 64 & 79 & 23184 \\ 91185 & 71 & 66 & 63 & 76 & 74 & 23192 \\ 91185 & 66 & 63 & 61 & 84 & 68 & 23192 \\ 91285 & 62 & 61 & 60 & 93 & 64 & 23192 \\ 91285 & 60 & 59 & 59 & 97 & 61 & 23192 \\ 91285 & 71 & 64 & 60 & 68 & 65 & 23193 \\ 91285 & 78 & 64 & 55 & 45 & 74 & 23212 \\ 91285 & 78 & 65 & 57 & 49 & 78 & 23236 \\ 91285 & 71 & 60 & 52 & 51 & 74 & 23244 \\ 91285 & 65 & 55 & 47 & 52 & 68 & 23244 \\ 91285 & 59 & 53 & 48 & 67 & 62 & 23244 \\ 91385 & 56 & 51 & 47 & 72 & 57 & 23244 \\ 91385 & 58 & 52 & 47 & 67 & 57 & 23244 \\ 91385 & 62 & 54 & 46 & 56 & 60 & 23244 \\ 91385 & 71 & 57 & 44 & 38 & 66 & 23246 \\ 91385 & 73 & 57 & 42 & 33 & 72 & 23253 \\ 91385 & 66 & 53 & 40 & 39 & 69 & 23253 \\ 91385 & 60 & 52 & 45 & 58 & 63 & 23253 \\ 91385 & 54 & 50 & 45 & 72 & 57 & 23253 \\ 91485 & 51 & 48 & 45 & 80 & 52 & 23253 \\ 91485 & 50 & 48 & 45 & 83 & 50 & 23253 \\ 91485 & 64 & 57 & 51 & 63 & 57 & 23253 \\ 91485 & 71 & 60 & 52 & 51 & 67 & 23255 \\ 91485 & 70 & 58 & 49 & 47 & 70 & 23256 \\ 91485 & 66 & 57 & 50 & 57 & 68 & 23256 \\ 91485 & 62 & 57 & 52 & 70 & 64 & 23256 \\ 91485 & 57 & 55 & 53 & 87 & 59 & 23256 \\ 91585 & 54 & 53 & 52 & 93 & 55 & 23256 \\ 91585 & 50 & 50 & 49 & 96 & 52 & 23256 \\ 91585 & 68 & 56 & 46 & 45 & 59 & 23256 \\ 91585 & 74 & 59 & 46 & 37 & 71 & 23263 \\ 91585 & 74 & 59 & 46 & 37 & 74 & 23275 \\ 91585 & 69 & 57 & 46 & 44 & 71 & 23277 \\ 91585 & 62 & 56 & 51 & 67 & 65 & 23277 \\ 91585 & 56 & 54 & 53 & 90 & 59 & 23277 \\ 91685 & 54 & 52 & 51 & 90 & 55 & 23277 \\ 91685 & 51 & 50 & 49 & 93 & 52 & 23277 \\ 91685 & 70 & 59 & 50 & 49 & 60 & 23277 \\ 91685 & 78 & 63 & 53 & 42 & 74 & 23295 \\ 91685 & 78 & 62 & 51 & 39 & 78 & 23319 \\ 91685 & 74 & 62 & 53 & 48 & 76 & 23334 \\ 91685 & 63 & 59 & 56 & 78 & 68 & 23334 \\ 91685 & 60 & 57 & 55 & 84 & 61 & 23334\end{array}$




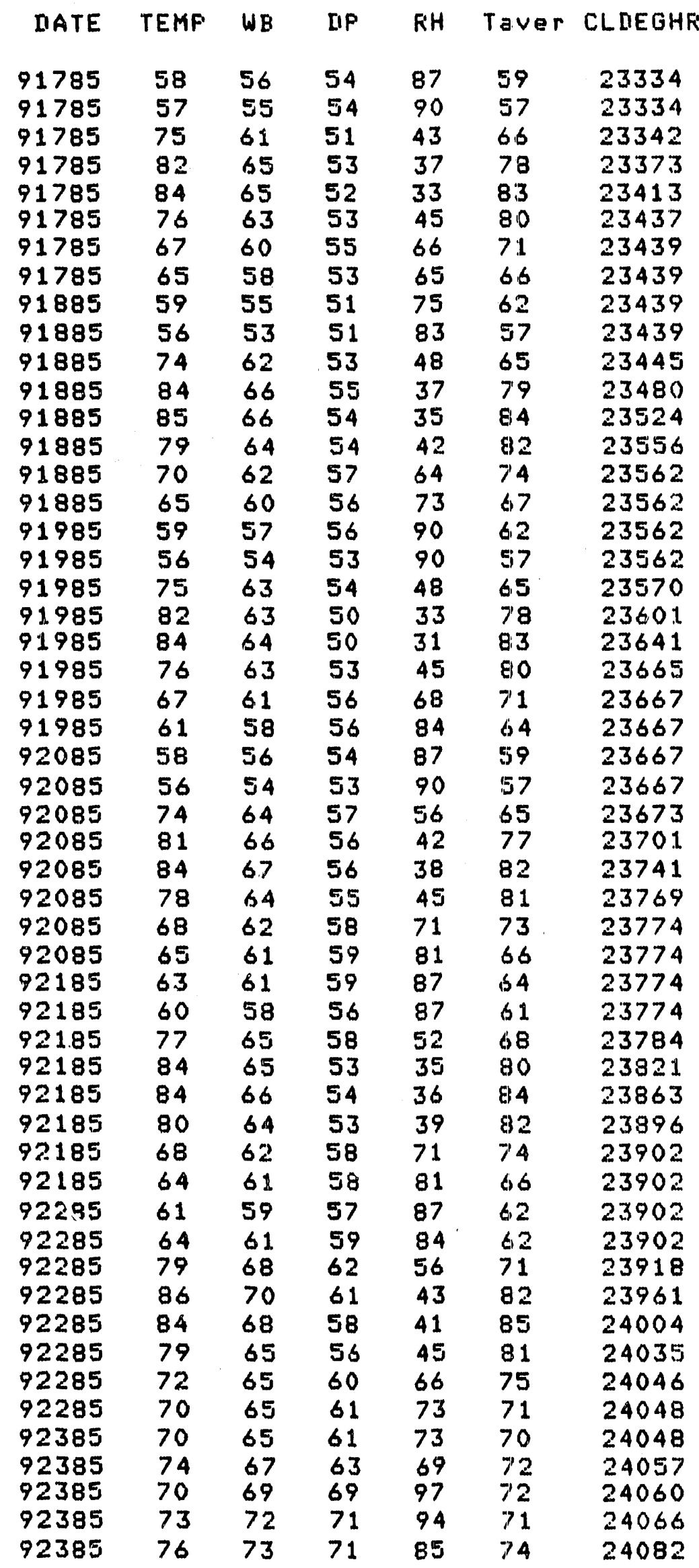




\begin{tabular}{|c|c|c|c|c|c|c|}
\hline DATE & TEMP & $W B$ & IIP & RH & Taver & CLDEGHR \\
\hline $\begin{array}{l}92385 \\
92385 \\
92385 \\
92485\end{array}$ & $\begin{array}{l}71 \\
70 \\
62 \\
56\end{array}$ & $\begin{array}{l}70 \\
69 \\
59 \\
52\end{array}$ & $\begin{array}{l}69 \\
68 \\
57 \\
49\end{array}$ & $\begin{array}{l}93 \\
93 \\
84 \\
78\end{array}$ & $\begin{array}{l}73 \\
70 \\
66 \\
59\end{array}$ & $\begin{array}{l}24089 \\
24090 \\
24090 \\
24090\end{array}$ \\
\hline $\begin{array}{l}92485 \\
92485 \\
92485\end{array}$ & $\begin{array}{l}51 \\
57 \\
64\end{array}$ & $\begin{array}{l}47 \\
50 \\
54\end{array}$ & $\begin{array}{l}43 \\
42 \\
45\end{array}$ & $\begin{array}{l}74 \\
58 \\
50\end{array}$ & $\begin{array}{l}53 \\
54 \\
60\end{array}$ & $\begin{array}{l}24090 \\
24090 \\
24090\end{array}$ \\
\hline $\begin{array}{l}92485 \\
92485 \\
92485\end{array}$ & $\begin{array}{l}71 \\
64 \\
55\end{array}$ & $\begin{array}{l}57 \\
52 \\
50\end{array}$ & $\begin{array}{l}44 \\
41 \\
45\end{array}$ & $\begin{array}{l}38 \\
43 \\
69\end{array}$ & $\begin{array}{l}67 \\
67 \\
59\end{array}$ & $\begin{array}{l}24091 \\
24091 \\
24091\end{array}$ \\
\hline $\begin{array}{r}92485 \\
9085\end{array}$ & $\begin{array}{l}51 \\
48\end{array}$ & $\begin{array}{l}48 \\
46\end{array}$ & $\begin{array}{l}45 \\
44\end{array}$ & $\begin{array}{l}80 \\
86\end{array}$ & $\begin{array}{l}53 \\
49\end{array}$ & $\begin{array}{l}24091 \\
24091\end{array}$ \\
\hline $\begin{array}{ll}9 & 085 \\
9 & 085 \\
9 & 085 \\
9 & 085\end{array}$ & $\begin{array}{l}46 \\
64 \\
80 \\
83\end{array}$ & $\begin{array}{l}45 \\
54 \\
62 \\
67\end{array}$ & $\begin{array}{l}43 \\
45 \\
49 \\
57\end{array}$ & $\begin{array}{l}89 \\
50 \\
34 \\
41\end{array}$ & $\begin{array}{l}47 \\
55 \\
72 \\
81\end{array}$ & $\begin{array}{l}24091 \\
24091 \\
24109 \\
24146\end{array}$ \\
\hline $\begin{array}{ll}9 & 085 \\
9 & 085\end{array}$ & 77 & 68 & 62 & 60 & 80 & $241>1$ \\
\hline 9085 & 67 & 65 & 64 & 90 & 72 & 24174 \\
\hline 9085 & 64 & 63 & 63 & 97 & 65 & 24174 \\
\hline 92685 & 61 & 60 & 59 & 93 & 62 & 24174 \\
\hline $\begin{array}{l}92685 \\
92685\end{array}$ & $\begin{array}{l}55 \\
60\end{array}$ & $\begin{array}{l}53 \\
56\end{array}$ & $\begin{array}{l}52 \\
52\end{array}$ & $\begin{array}{l}90 \\
75\end{array}$ & $\begin{array}{l}58 \\
57\end{array}$ & $\begin{array}{l}24174 \\
24174\end{array}$ \\
\hline 92685 & 66 & 58 & 51 & 59 & 63 & 24174 \\
\hline $\begin{array}{l}92685 \\
92685\end{array}$ & & $\begin{array}{l}57 \\
54\end{array}$ & $\begin{array}{l}48 \\
48\end{array}$ & $\begin{array}{l}49 \\
65\end{array}$ & $\begin{array}{l}67 \\
64\end{array}$ & $\begin{array}{l}24174 \\
24174\end{array}$ \\
\hline $\begin{array}{l}92685 \\
92685\end{array}$ & $\begin{array}{l}56 \\
53\end{array}$ & $\begin{array}{l}52 \\
51\end{array}$ & $\begin{array}{l}49 \\
49\end{array}$ & $\begin{array}{l}78 \\
86\end{array}$ & $\begin{array}{l}58 \\
54\end{array}$ & $\begin{array}{l}24174 \\
24174\end{array}$ \\
\hline 92785 & 51 & 49 & 47 & 86 & 52 & 24174 \\
\hline $\begin{array}{l}92785 \\
92785\end{array}$ & $\begin{array}{l}50 \\
57\end{array}$ & $\begin{array}{l}48 \\
51\end{array}$ & $\begin{array}{l}46 \\
46\end{array}$ & $\begin{array}{l}86 \\
67 \\
6\end{array}$ & $\begin{array}{l}50 \\
53\end{array}$ & $\begin{array}{l}24174 \\
24174\end{array}$ \\
\hline 92785 & 60 & 52 & 44 & 56 & 58 & 24174 \\
\hline 92785 & 65 & 54 & 43 & 45 & 62 & 24174 \\
\hline 92785 & 59 & 51 & 43 & 56 & 62 & 24174 \\
\hline 92785 & & 49 & 46 & 83 & 55 & 24174 \\
\hline 92785 & 48 & 47 & 46 & 93 & 49 & 24174 \\
\hline 92885 & 196 & 45 & 43 & 89 & 47 & 24174 \\
\hline 92885 & 47 & 47 & 47 & 0 & 46 & 24174 \\
\hline 92885 & 58 & 54 & 51 & 78 & 52 & 24174 \\
\hline 92885 & 69 & 57 & 46 & 44 & 63 & 24174 \\
\hline 92885 & 73 & 58 & 46 & 38 & 71 & 24180 \\
\hline 92885 & 68 & 56 & 46 & 45 & 70 & 24131 \\
\hline 92885 & 54 & 52 & 50 & 86 & 61 & 24181 \\
\hline 92885 & 55 & 52 & 49 & 80 & 54 & 24181 \\
\hline 92985 & 51 & 50 & 48 & 90 & 53 & 24181 \\
\hline 92985 & 50 & 49 & 48 & 93 & 50 & 24181 \\
\hline 92985 & 65 & 57 & 51 & $b 1$ & 57 & 241.81 \\
\hline 92985 & 78 & 61 & 45 & 36 & 71 & 24195 \\
\hline 92985 & 78 & 62 & 50 & 38 & 78 & 24219 \\
\hline 92985 & 70 & 59 & 50 & 49 & 74 & 24225 \\
\hline 92985 & 65 & 57 & 51 & 61 & 67 & 24225 \\
\hline 92985 & 6.3 & 57 & 52 & 68 & 64 & 24225 \\
\hline 93085 & 64 & 58 & 53 & 68 & 63 & 24225 \\
\hline 93085 & 64 & 59 & 55 & 73 & 64 & 24225 \\
\hline
\end{tabular}




$\begin{array}{rcccccc}\text { IIATE } & \text { TEMF } & \text { WB } & \text { IIF } & \text { FH } & \text { TaVER } & \text { CLDEGHF } \\ 93085 & 75 & 66 & 61 & 62 & 69 & 24233 \\ 93085 & 77 & 69 & 64 & 64 & 76 & 24252 \\ 93085 & 68 & 67 & 66 & 93 & 72 & 24256 \\ 93085 & 59 & 58 & 57 & 93 & 63 & 24256 \\ 93085 & 53 & 52 & 51 & 93 & 56 & 24256 \\ 93085 & 49 & 49 & 48 & 96 & 51 & 24256\end{array}$


IIATE TEMF WE IIF F'H TaVER CLIIEGHF

$\begin{array}{llllllll}5 & 186 & 66 & 59 & 53 & 63 & 67 & 1500 \\ 5 & 186 & 68 & 59 & 52 & 57 & 67 & 1500 \\ 5 & 186 & 65 & 63 & 61 & 87 & 66 & 1500 \\ 5 & 186 & 68 & 66 & 65 & 90 & 66 & 1500 \\ 5 & 186 & 73 & 64 & 59 & 62 & 70 & 1505 \\ 5 & 186 & 70 & 56 & 43 & 38 & 71 & 1507 \\ 5 & 186 & 59 & 55 & 52 & 78 & 64 & 1507 \\ 5 & 186 & 56 & 46 & 35 & 45 & 57 & 1507 \\ 5 & 286 & 51 & 45 & 39 & 64 & 53 & 1507 \\ 5 & 286 & 51 & 47 & 42 & 72 & 51 & 1507 \\ 5 & 286 & 60 & 51 & 41 & 50 & 55 & 1507 \\ 5 & 286 & 66 & 53 & 40 & 39 & 63 & 1507 \\ 5 & 286 & 70 & 53 & 35 & 28 & 68 & 1507 \\ 5 & 286 & 65 & 50 & 33 & 30 & 67 & 1507 \\ 5 & 286 & 56 & 46 & 35 & 45 & 60 & 1507 \\ 5 & 286 & 52 & 46 & 38 & 59 & 54 & 1507 \\ 5 & 386 & 47 & 41 & 34 & 61 & 49 & 1507 \\ 5 & 386 & 46 & 40 & 32 & 58 & 46 & 1507 \\ 5 & 386 & 55 & 43 & 26 & 33 & 50 & 1507 \\ 5 & 386 & 62 & 46 & 25 & 24 & 58 & 1507 \\ 5 & 386 & 51 & 45 & 24 & 24 & 61 & 1507 \\ 5 & 386 & 60 & 45 & 25 & 26 & 60 & 1507 \\ 5 & 386 & 52 & 42 & 28 & 40 & 56 & 1507 \\ 5 & 386 & 42 & 39 & 35 & 76 & 47 & 1507 \\ 5 & 486 & 38 & 36 & 34 & 36 & 40 & 1507 \\ 5 & 486 & 41 & 38 & 33 & 73 & 39 & 1507 \\ 5 & 486 & 60 & 46 & 29 & 31 & 50 & 1507 \\ 5 & 486 & 72 & 51 & 27 & 19 & 66 & 1510 \\ 5 & 486 & 78 & 54 & 29 & 17 & 75 & 1530 \\ 5 & 486 & 72 & 52 & 30 & 21 & 75 & 1540 \\ 5 & 486 & 58 & 46 & 32 & 19 & 65 & 1540 \\ 5 & 486 & 53 & 46 & 38 & 57 & 55 & 1540 \\ 5 & 586 & 52 & 45 & 38 & 59 & 52 & 1540 \\ 5 & 586 & 57 & 50 & 44 & 62 & 54 & 1540 \\ 5 & 586 & 74 & 62 & 53 & 48 & 65 & 1546 \\ 5 & 586 & 83 & 63 & 48 & 30 & 78 & 1578 \\ 5 & 586 & 86 & 62 & 44 & 23 & 84 & 1624 \\ 5 & 586 & 79 & 59 & 43 & 28 & 82 & 1656 \\ 5 & 586 & 70 & 57 & 46 & 42 & 74 & 1663 \\ 5 & 586 & 66 & 58 & 52 & 61 & 68 & 1663 \\ 5 & 686 & 63 & 57 & 53 & 70 & 64 & 1663 \\ 5 & 686 & 64 & 60 & 57 & 78 & 63 & 1663 \\ 5 & 686 & 76 & 68 & 63 & 64 & 70 & 1672 \\ 5 & 686 & 82 & 69 & 62 & 51 & 79 & 1704 \\ 5 & 686 & 84 & 69 & 60 & 44 & 83 & 1744 \\ 5 & 686 & 80 & 66 & 58 & 47 & 82 & 1777 \\ 5 & 686 & 69 & 62 & 58 & 68 & 74 & 1784 \\ 5 & 686 & 66 & 62 & 59 & 78 & 67 & 1784 \\ 5 & 786 & 62 & 60 & 59 & 90 & 64 & 1784 \\ 5 & 786 & 67 & 65 & 63 & 87 & 64 & 1784 \\ 5 & 786 & 80 & 71 & 66 & 63 & 73 & 1804 \\ 5 & 786 & 86 & 70 & 62 & 45 & 83 & 1848\end{array}$




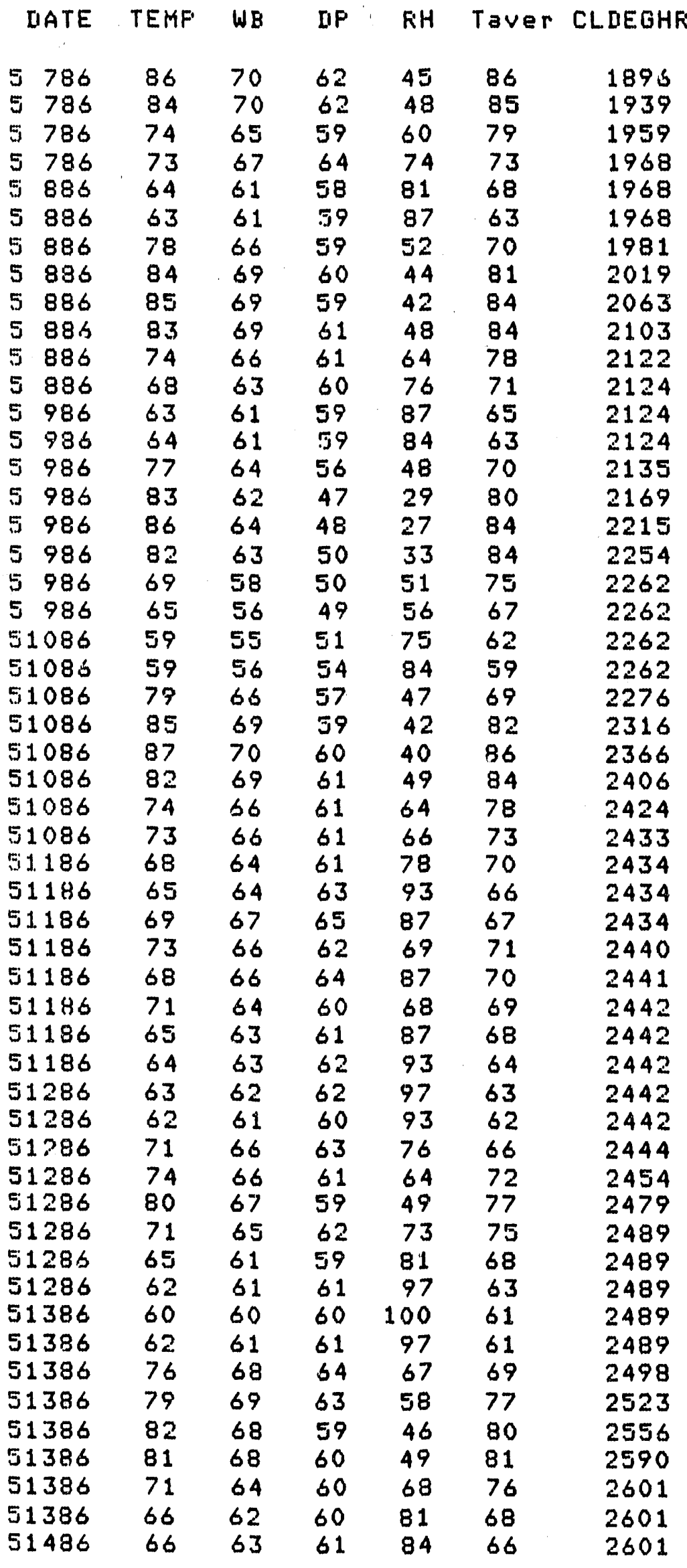




$\begin{array}{lllllll}\text { IIATE } & \text { TEMF } & \text { WB } & \text { IIF } & \text { FH } & \text { TaVer } & \text { CLIJEHR } \\ & & & & & & \\ 51486 & 67 & 62 & 59 & 76 & 66 & 2601 \\ 51486 & 80 & 70 & 64 & 58 & 73 & 2621 \\ 51186 & 84 & 69 & 61 & 46 & 82 & 2660 \\ 51486 & 87 & 69 & 59 & 39 & 85 & 2709 \\ 51486 & 80 & 67 & 59 & 49 & 83 & 2744 \\ 51486 & 77 & 66 & 59 & 54 & 78 & 2767 \\ 51486 & 64 & 61 & 58 & 81 & 70 & 2768 \\ 51586 & 63 & 60 & 58 & 84 & 63 & 2768 \\ 51586 & 69 & 64 & 60 & 73 & 66 & 2768 \\ 51586 & 78 & 66 & 58 & 50 & 73 & 2785 \\ 51586 & 81 & 66 & 57 & 44 & 79 & 2816 \\ 51586 & 82 & 66 & 56 & 41 & 81 & 2851 \\ 51586 & 78 & 65 & 57 & 49 & 80 & 2878 \\ 51586 & 73 & 63 & 57 & 57 & 75 & 2891 \\ 51586 & 70 & 65 & 61 & 73 & 71 & 2893 \\ 51686 & 65 & 61 & 59 & 81 & 67 & 2893 \\ 51636 & 68 & 64 & 62 & 81 & 66 & 2893 \\ 51686 & 74 & 67 & 63 & 69 & 71 & 2901 \\ 51686 & 86 & 68 & 58 & 39 & 80 & 2940 \\ 51686 & 88 & 67 & 53 & 30 & 87 & 2992 \\ 51686 & 83 & 65 & 54 & 37 & 85 & 3035 \\ 51686 & 73 & 63 & 57 & 57 & 78 & 3051 \\ 51686 & 66 & 62 & 60 & 81 & 69 & 3051 \\ 51786 & 65 & 62 & 60 & 84 & 65 & 3051 \\ 51786 & 68 & 64 & 62 & 81 & 66 & 3051 \\ 51786 & 82 & 70 & 64 & 55 & 75 & 3077 \\ 51786 & 85 & 69 & 59 & 42 & 83 & 3120 \\ 51786 & 85 & 68 & 58 & 40 & 85 & 3165 \\ 51786 & 81 & 68 & 60 & 49 & 83 & 3201 \\ 51786 & 75 & 66 & 61 & 62 & 78 & 3220 \\ 51786 & 73 & 64 & 58 & 60 & 74 & 3231 \\ 51886 & 73 & 65 & 60 & 64 & 73 & 3240 \\ 51886 & 67 & 65 & 63 & 87 & 70 & 3240 \\ 51886 & 67 & 68 & 65 & 93 & 67 & 3240 \\ 51886 & 76 & 68 & 63 & 64 & 71 & 3251 \\ 51886 & 72 & 68 & 66 & 82 & 74 & 3260 \\ 51886 & 62 & 61 & 61 & 97 & 67 & 3260 \\ 51886 & 62 & 61 & 60 & 93 & 62 & 3260 \\ 51886 & 60 & 59 & 58 & 93 & 61 & 3260 \\ 51986 & 58 & 57 & 56 & 93 & 59 & 3260 \\ 51986 & 55 & 55 & 54 & 97 & 56 & 3260 \\ 51986 & 56 & 54 & 53 & 90 & 55 & 3260 \\ 51966 & 60 & 57 & 54 & 81 & 58 & 3260 \\ 51986 & 64 & 58 & 54 & 70 & 62 & 3260 \\ 51986 & 63 & 57 & 53 & 70 & 63 & 3260 \\ 51986 & 60 & 54 & 48 & 65 & 61 & 3260 \\ 51986 & 57 & 54 & 52 & 84 & 58 & 3260 \\ 52086 & 52 & 51 & 50 & 93 & 54 & 3260 \\ 52086 & 51 & 50 & 49 & 93 & 51 & 3260 \\ 52086 & 55 & 51 & 48 & 77 & 53 & 3260 \\ 52086 & 60 & 53 & 47 & 62 & 57 & 3260 \\ 52086 & 62 & 54 & 46 & 56 & 61 & 3260 \\ 52086 & 60 & 53 & 46 & 60 & 61 & 3260\end{array}$




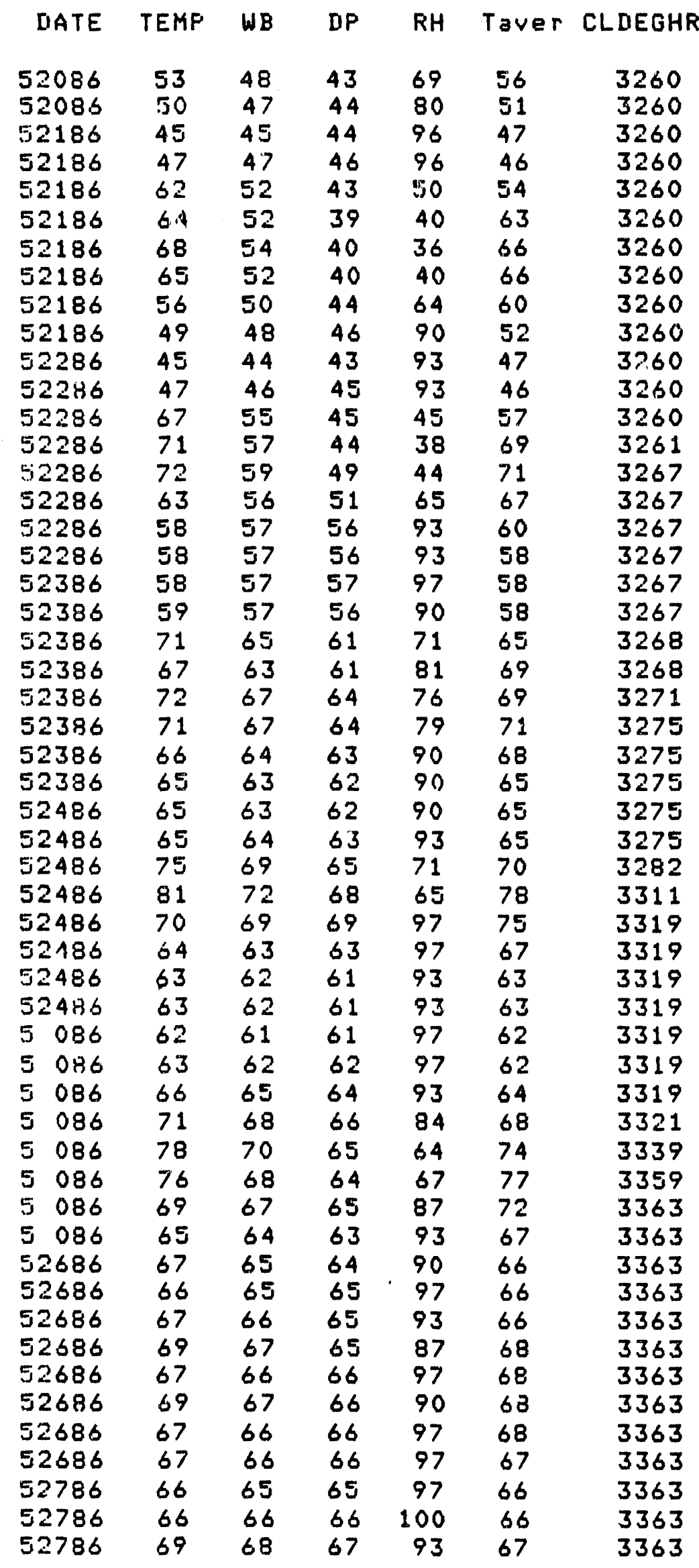


DATE TEMF WE DF RH TaVER CLDEGHR

$\begin{array}{lllllll}52786 & 78 & 71 & 68 & 72 & 73 & 3380 \\ 52786 & 79 & 72 & 68 & 69 & 78 & 3406 \\ 52786 & 71 & 69 & 68 & 90 & 75 & 3415 \\ 52786 & 68 & 67 & 67 & 97 & 69 & 3415 \\ 52786 & 66 & 66 & 66 & 100 & 67 & 3415 \\ 52886 & 66 & 66 & 66 & 100 & 66 & 3415 \\ 52886 & 66 & 66 & 66 & 100 & 66 & 3415 \\ 52886 & 67 & 66 & 66 & 97 & 66 & 3415 \\ 52886 & 68 & 67 & 66 & 93 & 67 & 3415 \\ 52886 & 73 & 69 & 67 & 82 & 70 & 3420 \\ 52886 & 73 & 69 & 66 & 79 & 73 & 3429 \\ 52886 & 67 & 66 & 66 & 97 & 70 & 3429 \\ 52886 & 66 & 65 & 65 & 97 & 66 & 3429 \\ 52986 & 65 & 65 & 65 & 100 & 65 & 3429 \\ 52986 & 69 & 68 & 67 & 93 & 67 & 3429 \\ 52986 & 76 & 70 & 67 & 74 & 72 & 3442 \\ 52986 & 82 & 71 & 66 & 59 & 79 & 3474 \\ 52986 & 80 & 65 & 56 & 44 & 81 & 3505 \\ 52986 & 80 & 69 & 63 & 56 & 80 & 3535 \\ 52986 & 70 & 69 & 68 & 93 & 75 & 3543 \\ 52986 & 68 & 67 & 67 & 97 & 69 & 3543 \\ 53086 & 65 & 64 & 64 & 97 & 66 & 3543 \\ 53086 & 67 & 67 & 67 & 100 & 66 & 3543 \\ 53086 & 78 & 72 & 69 & 74 & 72 & 3558 \\ 53086 & 78 & 71 & 67 & 69 & 78 & 3582 \\ 53086 & 82 & 70 & 63 & 53 & 80 & 3615 \\ 53086 & 80 & 69 & 63 & 56 & 81 & 3647 \\ 53086 & 74 & 68 & 64 & 71 & 77 & 3663 \\ 53086 & 69 & 67 & 66 & 90 & 71 & 3666 \\ 53186 & 65 & 64 & 64 & 97 & 67 & 3666 \\ 53186 & 66 & 65 & 64 & 93 & 65 & 3666 \\ 53186 & 79 & 71 & 66 & 65 & 72 & 3683 \\ 53186 & 81 & 70 & 64 & 56 & 80 & 3714 \\ 53186 & 82 & 70 & 64 & 55 & 81 & 3750 \\ 53186 & 77 & 70 & 66 & 69 & 79 & 3774 \\ 53186 & 71 & 68 & 67 & 87 & 74 & 3782 \\ 53186 & 69 & 68 & 67 & 93 & 70 & 3782 \\ 6186 & 66 & 65 & 65 & 97 & 67 & 3782 \\ 6186 & 68 & 67 & 66 & 93 & 67 & 3782 \\ 6186 & 80 & 72 & 68 & 67 & 74 & 3803 \\ 6186 & 85 & 71 & 64 & 50 & 82 & 3844 \\ 6186 & 87 & 72 & 65 & 48 & 86 & 3894 \\ 6186 & 81 & 71 & 66 & 60 & 84 & 3931 \\ 6186 & 71 & 67 & 65 & 81 & 76 & 3942 \\ 6186 & 67 & 66 & 65 & 93 & 69 & 3942 \\ 62966 & 66 & 65 & 65 & 97 & 66 & 3942 \\ 6286 & 70 & 68 & 67 & 90 & 68 & 3942 \\ 6286 & 78 & 71 & 67 & 69 & 74 & 3960 \\ 6286 & 84 & 73 & 68 & 59 & 81 & 3997 \\ 62886 & 83 & 72 & 66 & 57 & 83 & 4037 \\ 6286 & 76 & 72 & 70 & 82 & 79 & 4060 \\ 6286 & 69 & 66 & 64 & 84 & 72 & 4064 \\ 6286 & 67 & 64 & 62 & 84 & 68 & 4064\end{array}$


DATE TEMF WB DP RH TaVET CLDEGHF

$\begin{array}{llllllll}6 & 386 & 63 & 62 & 61 & 93 & 65 & 4064 \\ 6 & 386 & 65 & 64 & 63 & 93 & 64 & 4064 \\ 6 & 386 & 71 & 67 & 65 & 81 & 68 & 4065 \\ 6 & 386 & 81 & 73 & 69 & 67 & 76 & 4091 \\ 6 & 386 & 82 & 73 & 68 & 63 & 81 & 4126 \\ 6 & 386 & 71 & 69 & 68 & 90 & 76 & 4137 \\ 6 & 386 & 69 & 68 & 68 & 97 & 70 & 4137 \\ 6 & 386 & 68 & 66 & 65 & 90 & 68 & 4137 \\ 6 & 486 & 65 & 63 & 62 & 90 & 66 & 4137 \\ 6 & 486 & 66 & 64 & 62 & 87 & 65 & 4137 \\ 6 & 486 & 73 & 68 & 65 & 76 & 69 & 4142 \\ 6 & 486 & 72 & 69 & 67 & 84 & 72 & 4149 \\ 6 & 486 & 74 & 70 & 68 & 82 & 73 & 4159 \\ 6 & 486 & 74 & 69 & 67 & 79 & 74 & 4171 \\ 6 & 486 & 71 & 68 & 67 & 87 & 72 & 4176 \\ 6 & 186 & 71 & 69 & 68 & 90 & 71 & 4179 \\ 6 & 586 & 70 & 69 & 68 & 93 & 70 & 4180 \\ 6 & 586 & 69 & 68 & 68 & 97 & 69 & 4180 \\ 6 & 586 & 76 & 71 & 69 & 79 & 72 & 4193 \\ 6 & 586 & 77 & 73 & 71 & 82 & 76 & 4213 \\ 6 & 586 & 76 & 73 & 72 & 88 & 76 & 4232 \\ 6 & 586 & 75 & 72 & 71 & 87 & 75 & 4248 \\ 6 & 586 & 72 & 71 & 70 & 94 & 73 & 4256 \\ 6 & 586 & 71 & 70 & 70 & 97 & 71 & 4260 \\ 6 & 686 & 69 & 68 & 68 & 97 & 70 & 4260 \\ 6 & 686 & 70 & 69 & 69 & 97 & 69 & 4260 \\ 6 & 686 & 78 & 73 & 70 & 77 & 74 & 4278 \\ 6 & 686 & 76 & 71 & 69 & 79 & 77 & 4297 \\ 6 & 686 & 72 & 71 & 70 & 94 & 74 & 4306 \\ 6 & 686 & 74 & 73 & 72 & 94 & 73 & 4317 \\ 6 & 686 & 71 & 70 & 70 & 97 & 72 & 4322 \\ 6 & 686 & 69 & 69 & 69 & 100 & 70 & 4322 \\ 6 & 786 & 67 & 67 & 67 & 100 & 68 & 4322 \\ 6 & 786 & 70 & 69 & 69 & 97 & 68 & 4322 \\ 6 & 786 & 73 & 72 & 71 & 94 & 71 & 4329 \\ 6 & 786 & 82 & 75 & 72 & 72 & 77 & 4358 \\ 6 & 786 & 76 & 74 & 73 & 91 & 79 & 4380 \\ 6 & 786 & 79 & 75 & 73 & 82 & 77 & 4405 \\ 6 & 786 & 73 & 70 & 69 & 87 & 76 & 4419 \\ 6 & 786 & 73 & 72 & 72 & 97 & 73 & 4428 \\ 6 & 886 & 70 & 69 & 69 & 97 & 71 & 4430 \\ 6 & 886 & 73 & 72 & 72 & 97 & 71 & 4437 \\ 6 & 886 & 78 & 75 & 73 & 85 & 75 & 4457 \\ 6 & 886 & 84 & 75 & 71 & 65 & 31 & 4494 \\ 6 & 886 & 85 & 76 & 72 & 65 & 84 & 4539 \\ 6 & 886 & 72 & 71 & 71 & 97 & 78 & 4554 \\ 6 & 886 & 72 & 71 & 70 & 94 & 72 & 4560 \\ 6 & 886 & 72 & 71 & 71 & 97 & 72 & 4566 \\ 6 & 986 & 70 & 69 & 69 & 97 & 71 & 4568 \\ 6 & 986 & 73 & 71 & 70 & 90 & 71 & 4575 \\ 6 & 986 & 79 & 75 & 73 & 82 & 76 & 4597 \\ 6 & 986 & 85 & 77 & 73 & 67 & 82 & 4638 \\ 6 & 986 & 72 & 71 & 70 & 94 & 78 & 4653\end{array}$




$\begin{array}{lllllll}\text { DATE } & \text { TEMF } & \text { WB } & \text { IF } & \text { RH } & \text { TaVer } & \text { CLDEGHR } \\ & & & & & & \\ 6986 & 73 & 72 & 71 & 94 & 72 & 4662 \\ 6986 & 71 & 70 & 70 & 97 & 72 & 4666 \\ 61986 & 71 & 70 & 70 & 97 & 71 & 4669 \\ 61086 & 71 & 70 & 70 & 97 & 71 & 4672 \\ 61086 & 73 & 72 & 71 & 94 & 72 & 4680 \\ 61086 & 76 & 74 & 73 & 91 & 74 & 4695 \\ 61086 & 82 & 76 & 74 & 77 & 79 & 4727 \\ 61086 & 86 & 77 & 73 & 65 & 84 & 4772 \\ 61086 & 82 & 76 & 73 & 74 & 84 & 4811 \\ 61086 & 77 & 74 & 72 & 85 & 79 & 4836 \\ 61086 & 74 & 71 & 69 & 85 & 75 & 4850 \\ 61186 & 71 & 69 & 68 & 90 & 72 & 4855 \\ 61186 & 73 & 71 & 70 & 90 & 72 & 4863 \\ 61186 & 78 & 74 & 72 & 82 & 75 & 4883 \\ 61186 & 85 & 78 & 75 & 72 & 81 & 4923 \\ 61186 & 83 & 74 & 70 & 65 & 84 & 4963 \\ 61186 & 81 & 74 & 71 & 72 & 82 & 4998 \\ 61186 & 74 & 73 & 73 & 97 & 77 & 5015 \\ 61186 & 72 & 71 & 70 & 94 & 73 & 5022 \\ 61286 & 71 & 70 & 69 & 93 & 71 & 5026 \\ 61286 & 72 & 69 & 67 & 84 & 71 & 5031 \\ 61286 & 75 & 67 & 63 & 66 & 73 & 5044 \\ 61286 & 79 & 68 & 62 & 56 & 77 & 5068 \\ 61286 & 79 & 68 & 61 & 54 & 79 & 5095 \\ 61286 & 79 & 68 & 62 & 56 & 79 & 5122 \\ 61286 & 72 & 66 & 63 & 73 & 75 & 5133 \\ 61286 & 66 & 64 & 63 & 90 & 69 & 5133 \\ 61386 & 65 & 63 & 62 & 90 & 65 & 5133 \\ 61386 & 66 & 63 & 61 & 84 & 65 & 5133 \\ 61386 & 70 & 63 & 59 & 68 & 68 & 5133 \\ 61386 & 74 & 65 & 60 & 62 & 72 & 5142 \\ 61386 & 76 & 67 & 61 & 60 & 75 & 5159 \\ 61336 & 73 & 66 & 61 & 66 & 74 & 5170 \\ 61386 & 65 & 62 & 60 & 84 & 69 & 5170 \\ 61386 & 63 & 61 & 60 & 90 & 64 & 5170 \\ 61486 & 60 & 59 & 59 & 97 & 61 & 5170 \\ 61486 & 62 & 61 & 61 & 97 & 61 & 5170 \\ 61486 & 74 & 68 & 65 & 74 & 68 & 5176 \\ 61486 & 82 & 71 & 66 & 59 & 78 & 5206 \\ 61486 & 84 & 71 & 64 & 51 & 83 & 5247 \\ 61486 & 81 & 71 & 65 & 58 & 82 & 5282 \\ 61486 & 73 & 69 & 67 & 82 & 77 & 5297 \\ 61486 & 71 & 68 & 66 & 84 & 72 & 5301 \\ 61586 & 65 & 64 & 63 & 93 & 68 & 5301 \\ 61586 & 66 & 65 & 64 & 93 & 65 & 5301 \\ 61586 & 80 & 71 & 66 & 63 & 73 & 5321 \\ 61586 & 82 & 71 & 66 & 59 & 81 & 5355 \\ 61586 & 84 & 70 & 63 & 49 & 83 & 5396 \\ 61686 & 81 & 71 & 65 & 58 & 82 & 5431 \\ 61586 & 62 & 68 & 66 & 82 & 76 & 5444 \\ 67 & 66 & 65 & 93 & 69 & 5444 \\ 67 & 65 & 63 & 87 & 66 & 5444\end{array}$




\begin{tabular}{|c|c|c|c|c|c|c|}
\hline IIATE & TEMF' & WE & {$[I F$} & FH & Taver & CLIIEGHF \\
\hline 61686 & 82 & 70 & 64 & 55 & 74 & 5469 \\
\hline 61686 & 87 & 71 & 62 & 43 & 84 & 5516 \\
\hline 61586 & 88 & 71 & 61 & 40 & 87 & 5569 \\
\hline 61686 & 84 & 71 & 64 & 51 & 86 & 5614 \\
\hline 61686 & 73 & 68 & 65 & 76 & 78 & 5631 \\
\hline 61686 & 69 & 67 & 65 & 87 & 71 & 5633 \\
\hline 61786 & 67 & 65 & 63 & 87 & 68 & 5633 \\
\hline 61786 & 73 & 69 & 67 & 82 & 70 & 5637 \\
\hline 61786 & 82 & 74 & 70 & 67 & 77 & 5667 \\
\hline 61786 & 86 & 71 & 63 & 46 & 84 & 5712 \\
\hline 61786 & 84 & 68 & 59 & 43 & 85 & 5755 \\
\hline 61786 & 79 & 66 & 58 & 49 & 81 & 5786 \\
\hline 61786 & 69 & 62 & 58 & 68 & 74 & 5792 \\
\hline 61786 & 63 & 58 & 54 & 73 & 66 & 5792 \\
\hline 51886 & 58 & 55 & 63 & 81 & 60 & 5792 \\
\hline 61886 & 62 & 57 & 67 & 70 & 60 & 5792 \\
\hline 61886 & 73 & 61 & 70 & 50 & 67 & 5796 \\
\hline 61886 & 79 & 64 & 63 & 41 & 76 & 5819 \\
\hline $\begin{array}{l}61886 \\
61886\end{array}$ & $\begin{array}{l}82 \\
79\end{array}$ & $\begin{array}{l}65 \\
65\end{array}$ & $\begin{array}{l}59 \\
58\end{array}$ & $\begin{array}{l}37 \\
45\end{array}$ & $\begin{array}{l}80 \\
80\end{array}$ & $\begin{array}{l}5853 \\
5882\end{array}$ \\
\hline 61896 & 70 & 62 & 58 & 64 & 74 & 5889 \\
\hline 61886 & 66 & 61 & 54 & 76 & 68 & 5889 \\
\hline 61986 & 64 & 60 & 57 & 78 & 65 & 5889 \\
\hline 61986 & 65 & 61 & 59 & 81 & 64 & 5889 \\
\hline 61986 & 79 & 66 & 58 & 49 & 72 & 5905 \\
\hline 61986 & 88 & 68 & 55 & 33 & 83 & 5952 \\
\hline 61986 & 89 & 67 & 54 & 30 & 88 & 6009 \\
\hline 61986 & 86 & 67 & 55 & 35 & 87 & 6059 \\
\hline 61986 & 78 & 67 & 60 & 54 & 82 & 6089 \\
\hline 61986 & 72 & 67 & 64 & 76 & 75 & 6099 \\
\hline 62080 & 67 & 65 & 63 & 87 & 69 & 6099 \\
\hline 62086 & 69 & 67 & 65 & 87 & 68 & 6099 \\
\hline 62086 & 84 & 72 & 66 & 55 & 76 & 6130 \\
\hline 62086 & 88 & 73 & 66 & 4.3 & 86 & 6181 \\
\hline 62086 & 91 & 72 & 63 & 35 & 89 & 6242 \\
\hline 62086 & 87 & 69 & 59 & 39 & 89 & 6296 \\
\hline 62086 & 79 & 69 & 64 & 60 & 83 & 6329 \\
\hline 62086 & 71 & 67 & 64 & 79 & 75 & 6338 \\
\hline 62186 & 69 & 67 & 65 & 87 & 70 & 6338 \\
\hline 62186 & 70 & 68 & 66 & 87 & 69 & 6338 \\
\hline 52186 & 86 & 75 & 70 & 59 & 78 & 6374 \\
\hline 62186 & 90 & 76 & 70 & 52 & 88 & 6431 \\
\hline 62186 & 93 & 75 & 66 & 41 & 91 & 6498 \\
\hline 62186 & 88 & 75 & 69 & 53 & 90 & 6555 \\
\hline 62186 & 79 & 74 & 71 & 77 & 83 & 6589 \\
\hline 62186 & 73 & 72 & 71 & 94 & 76 & 6603 \\
\hline 62286 & 72 & 70 & 69 & 90 & 72 & 6609 \\
\hline 62286 & 72 & 71 & 71 & 97 & 72 & 6615 \\
\hline 62286 & 85 & 74 & 69 & 59 & 78 & 6651 \\
\hline 62286 & 94 & 74 & 64 & 37 & 89 & 6716 \\
\hline 62286 & 93 & 71 & 60 & 33 & 93 & 6786 \\
\hline 62286 & 90 & 73 & 64 & 42 & 91 & 6848 \\
\hline 62286 & 82 & 73 & 69 & 65 & 86 & 6890 \\
\hline
\end{tabular}




$\begin{array}{lllllll}\text { IIATE } & \text { TEMF } & \text { WE } & \text { IIF } & \text { FH } & \text { T3VER CLIIEGHF } \\ 62786 & 73 & 70 & 69 & 87 & 77 & 6906 \\ 62386 & 73 & 71 & 70 & 90 & 73 & 6915 \\ 62386 & 75 & 72 & 70 & 85 & 74 & 6928 \\ 62386 & 86 & 75 & 70 & 59 & 80 & 6968 \\ 62386 & 91 & 75 & 68 & 47 & 88 & 7027 \\ 62386 & 92 & 75 & 68 & 46 & 91 & 7092 \\ 62386 & 89 & 75 & 68 & 50 & 90 & 7152 \\ 62386 & 73 & 70 & 69 & 87 & 81 & 7173 \\ 62386 & 70 & 69 & 68 & 93 & 71 & 7175 \\ 62486 & 69 & 68 & 68 & 97 & 69 & 7175 \\ 62486 & 70 & 69 & 69 & 97 & 69 & 7175 \\ 62486 & 79 & 74 & 71 & 77 & 74 & 7195 \\ 62486 & 85 & 73 & 67 & 55 & 82 & 7236 \\ 62486 & 88 & 71 & 62 & 42 & 86 & 7287 \\ 62486 & 86 & 70 & 61 & 43 & 87 & 7337 \\ 62486 & 77 & 70 & 66 & 69 & 81 & 7365 \\ 62486 & 72 & 66 & 63 & 73 & 74 & 7374 \\ 6086 & 68 & 62 & 57 & 68 & 70 & 7374 \\ 6086 & 67 & 62 & 58 & 73 & 67 & 7374 \\ 6086 & 77 & 66 & 60 & 56 & 72 & 7388 \\ 6086 & 82 & 67 & 58 & 44 & 79 & 7420 \\ 6086 & 84 & 65 & 52 & 33 & 83 & 7461 \\ 6086 & 81 & 64 & 52 & 37 & 82 & 7496 \\ 6086 & 72 & 64 & 58 & 62 & 76 & 7509 \\ 6086 & 65 & 61 & 58 & 78 & 68 & 7509 \\ 62686 & 62 & 61 & 60 & 93 & 63 & 7509 \\ 62686 & 63 & 61 & 60 & 90 & 62 & 7509 \\ 62686 & 82 & 70 & 64 & 55 & 72 & 7530 \\ 62686 & 87 & 71 & 62 & 43 & 84 & 7578 \\ 62686 & 90 & 72 & 62 & 39 & 88 & 7635 \\ 62686 & 87 & 71 & 63 & 45 & 88 & 7689 \\ 62686 & 78 & 71 & 67 & 69 & 82 & 7719 \\ 62686 & 74 & 71 & 69 & 85 & 76 & 7734 \\ 62786 & 71 & 68 & 66 & 84 & 72 & 7740 \\ 62786 & 76 & 71 & 69 & 79 & 73 & 7754 \\ 62786 & 86 & 76 & 71 & 61 & 81 & 7794 \\ 629866 & 81 & 75 & 73 & 77 & 77 & 8242 \\ 62786 & 92 & 78 & 72 & 52 & 89 & 7856 \\ 62786 & 93 & 77 & 70 & 47 & 92 & 7924 \\ 62786 & 89 & 74 & 67 & 48 & 91 & 7984 \\ 62786 & 81 & 71 & 66 & 60 & 85 & 8023 \\ 62786 & 74 & 63 & 56 & 54 & 77 & 8040 \\ 62886 & 71 & 68 & 66 & 84 & 72 & 8046 \\ 62886 & 74 & 69 & 67 & 79 & 72 & 8055 \\ 62886 & 81 & 74 & 70 & 69 & 77 & 8083 \\ 62886 & 81 & 73 & 69 & 67 & 81 & 8116 \\ 62886 & 79 & 74 & 72 & 79 & 80 & 8145 \\ 6286 & 76 & 73 & 72 & 88 & 77 & 8165 \\ 62 & 74 & 73 & 73 & 97 & 74 & 8190 \\ 63 & 74 & 73 & 63 & 84 & 8289\end{array}$




\begin{tabular}{|c|c|c|c|c|c|c|}
\hline DATE & TEMF' & WB & IIF & $\mathrm{FiH}$ & Taver & CLIIEGHF \\
\hline \multirow{3}{*}{$\begin{array}{l}62986 \\
62986 \\
62986\end{array}$} & 87 & 77 & 73 & 63 & 87 & 8340 \\
\hline & 83 & 75 & 72 & 70 & 85 & 8382 \\
\hline & 76 & 74 & 73 & 91 & 79 & 8405 \\
\hline \multirow{2}{*}{$\begin{array}{l}62986 \\
63086\end{array}$} & 74 & 71 & 70 & 87 & 75 & 8418 \\
\hline & 72 & 71 & 70 & 94 & 73 & 8426 \\
\hline 63086 & 74 & 72 & 71 & 90 & 73 & 8436 \\
\hline \multirow{3}{*}{$\begin{array}{l}63086 \\
63086 \\
63086\end{array}$} & 82 & 76 & 73 & 74 & 78 & 8466 \\
\hline & 87 & 77 & 72 & 61 & 84 & 8514 \\
\hline & 90 & 77 & 71 & 54 & 88 & 8571 \\
\hline \multirow{2}{*}{$\begin{array}{l}63086 \\
63086\end{array}$} & 86 & 76 & 71 & 61 & 88 & 8622 \\
\hline & 76 & 71 & 69 & 79 & 81 & 8648 \\
\hline 63086 & 74 & 69 & 66 & 76 & 75 & 8661 \\
\hline 7186 & 73 & 71 & 70 & 90 & 73 & 8,671 \\
\hline \multirow{2}{*}{$\begin{array}{l}186 \\
7186\end{array}$} & 75 & 73 & 72 & 90 & 74 & 8685 \\
\hline & 83 & 76 & 73 & 72 & 79 & 8718 \\
\hline 7186 & 86 & 77 & 73 & 65 & 84 & 8763 \\
\hline \multirow{2}{*}{$\begin{array}{ll}7 & 186 \\
7 & 186\end{array}$} & 90 & 74 & 67 & 47 & 88 & 8820 \\
\hline & 88 & 76 & 70 & 55 & 89 & 8876 \\
\hline \multirow{2}{*}{$\begin{array}{ll}7 & 186 \\
7 & 186\end{array}$} & 81 & 74 & 71 & 72 & 84 & 8914 \\
\hline & 80 & 73 & 69 & 69 & 80 & 8945 \\
\hline \multirow{2}{*}{$\begin{array}{ll}7 & 286 \\
7 & 286\end{array}$} & 73 & 71 & 70 & 90 & 76 & 8959 \\
\hline & 73 & 72 & 71 & 94 & 73 & 8968 \\
\hline $\begin{array}{l}786 \\
7286\end{array}$ & 74 & 72 & 71 & 90 & 73 & 8979 \\
\hline 7286 & 77 & 70 & 67 & 71 & 75 & 8998 \\
\hline \multirow{2}{*}{$\begin{array}{l}7286 \\
7 \\
286\end{array}$} & 76 & 68 & 63 & 64 & 76 & 9017 \\
\hline & 77 & 68 & 62 & 60 & 76 & 9037 \\
\hline \multirow{2}{*}{$\begin{array}{ll}7 & 286 \\
7 & 286\end{array}$} & 72 & 66 & 6) 3 & 73 & 74 & 9047 \\
\hline & 66 & 65 & 65 & 97 & 69 & 9047 \\
\hline 7386 & 67 & 65 & 64 & 90 & 66 & 9047 \\
\hline 7386 & 68 & 66 & 65 & 90 & 67 & 9047 \\
\hline 7386 & 75 & 68 & 64 & 69 & 71 & 9057 \\
\hline 7386 & 80 & 65 & 56 & 44 & 77 & 9083 \\
\hline 7386 & 83 & 66 & 56 & 40 & 81 & 9120 \\
\hline 7386 & 80 & 65 & 55 & 42 & 81 & 9152 \\
\hline 7336 & 71 & 63 & 58 & 64 & 75 & 9162 \\
\hline 7386 & 65 & 62 & 60 & 84 & 68 & 9162 \\
\hline 7486 & 62 & so & 59 & 90 & 63 & 9162 \\
\hline 7486 & 64 & 62 & 60 & 87 & 63 & 9162 \\
\hline 7486 & 80 & 67 & 59 & 49 & 72 & 9180 \\
\hline 7486 & 85 & 67 & 56 & 37 & 82 & 9221 \\
\hline 7486 & 87 & 67 & 54 & 32 & 86 & 9270 \\
\hline 7486 & 85 & 68 & 58 & 40 & 86 & 9317 \\
\hline 7486 & 73 & 65 & 59 & 62 & 79 & 9335 \\
\hline 7486 & 68 & 63 & 60 & 76 & 70 & 9336 \\
\hline 7586 & 66 & 62 & 59 & 78 & 67 & 9336 \\
\hline 7586 & 67 & 65 & 64 & 90 & 66 & 9336 \\
\hline 7586 & 84 & 72 & 65 & 53 & 75 & 9365 \\
\hline 7586 & 91 & 71 & 61 & 37 & 87 & 9423 \\
\hline 7586 & 91 & 72 & 63 & 39 & 91 & 9486 \\
\hline 7586 & 88 & 72 & 63 & 43 & 89 & 9542 \\
\hline 7586 & 78 & 71 & 67 & 69 & 83 & 9573 \\
\hline 7586 & 74 & 70 & 68 & 82 & 76 & 9588 \\
\hline 7686 & 74 & 70 & 67 & 79 & 74 & 9600 \\
\hline
\end{tabular}




\begin{tabular}{|c|c|c|c|c|c|c|}
\hline IIATE & TEMF' & WB & [IF' & FH & Taver & CLIIEGHF \\
\hline 7686 & 74 & 59 & 66 & 76 & 74 & 9612 \\
\hline 7686 & 86 & 73 & 67 & 53 & 80 & 9651 \\
\hline 7686 & 92 & 74 & 66 & 42 & 89 & 9713 \\
\hline 7686 & 93 & 74 & 64 & 38 & 92 & 9781 \\
\hline 7686 & 88 & 73 & 66 & 48 & 90 & 9839 \\
\hline 7686 & 79 & 72 & 68 & 69 & 83 & 9873 \\
\hline 7686 & 77 & 70 & 67 & 71 & 78 & 9895 \\
\hline 7786 & 71 & 69 & 68 & 90 & 74 & 9903 \\
\hline 7786 & 73 & 71 & 70 & 90 & 72 & 9910 \\
\hline 7786 & 86 & 74 & 69 & 57 & 79 & 9948 \\
\hline 7786 & 92 & 74 & 66 & 42 & 89 & 10010 \\
\hline 7786 & 95 & 75 & 65 & 37 & 93 & 10083 \\
\hline 7786 & 88 & 74 & 67 & 50 & 91 & 10142 \\
\hline 7786 & 82 & 73 & 69 & 65 & 85 & 10182 \\
\hline 7786 & 77 & 72 & 70 & 79 & 79 & 10207 \\
\hline 7886 & 74 & 72 & 71 & 90 & 75 & 10221 \\
\hline 7886 & 76 & 73 & 71 & 85 & 75 & 10238 \\
\hline 7886 & 87 & 76 & 71 & 59 & 81 & 10281 \\
\hline 7886 & 90 & 75 & 68 & 48 & 88 & 10338 \\
\hline 7886 & 95 & 76 & 68 & 41 & 92 & 10410 \\
\hline 7886 & 91 & 76 & 69 & 49 & 93 & 10476 \\
\hline 7886 & 82 & 75 & 72 & 72 & 86 & 10518 \\
\hline 7885 & 79 & 74 & 71 & 77 & 80 & 10548 \\
\hline 7986 & 80 & 74 & 71 & 74 & 79 & 10577 \\
\hline 7986 & 80 & 75 & 72 & 77 & 80 & 10607 \\
\hline 7986 & 87 & 78 & 74 & 65 & 83 & 10653 \\
\hline 7986 & 91 & 78 & 72 & 54 & 89 & 10713 \\
\hline 7986 & 92 & 78 & 72 & 52 & 91 & 10778 \\
\hline 7996 & 84 & 74 & 69 & 61 & 88 & 10826 \\
\hline 7986 & 78 & 73 & 70 & 77 & 81 & 10854 \\
\hline 7986 & 77 & 71 & 68 & 74 & 77 & 10876 \\
\hline 71086 & 77 & 73 & 71 & 82 & 77 & 10397 \\
\hline 71086 & 77 & 74 & 72 & 85 & 77 & 10918 \\
\hline 71086 & 86 & 78 & 74 & 68 & 81 & 10959 \\
\hline 71086 & 90 & 78 & 73 & 58 & 88 & 11016 \\
\hline 71086 & 94 & 75 & 67 & 41 & 92 & 11085 \\
\hline $\begin{array}{l}71086 \\
71086\end{array}$ & $\begin{array}{l}79 \\
75\end{array}$ & $\begin{array}{l}72 \\
71\end{array}$ & $\begin{array}{l}69 \\
69\end{array}$ & $\begin{array}{l}72 \\
82\end{array}$ & $\begin{array}{l}83 \\
77\end{array}$ & $\begin{array}{l}11124 \\
11142\end{array}$ \\
\hline 71086 & 76 & 71 & 69 & 79 & 75 & 11159 \\
\hline 71186 & 73 & 71 & 70 & 90 & 74 & 11170 \\
\hline 71186 & 77 & 73 & 71 & 82 & 75 & 11188 \\
\hline 71186 & 81 & 75 & 72 & 74 & 79 & 11218 \\
\hline 71186 & 88 & 76 & 70 & 55 & 84 & 11267 \\
\hline 71186 & 90 & 76 & 70 & 52 & 89 & 11325 \\
\hline 71186 & 89 & 73 & 65 & 45 & 89 & 11383 \\
\hline 71186 & 81 & 72 & 67 & 63 & 85 & 11422 \\
\hline 71186 & 79 & 73 & 70 & 74 & 80 & 11451 \\
\hline 71286 & $7 \%$ & 72 & 70 & 79 & 78 & 11473 \\
\hline 71286 & 76 & 72 & 70 & 82 & 76 & 11492 \\
\hline 71286 & 80 & 75 & 72 & 77 & 78 & 11519 \\
\hline 71286 & 89 & 76 & 70 & 54 & 84 & 11569 \\
\hline 71286 & 93 & 76 & 68 & 44 & 91 & 11635 \\
\hline 71286 & 87 & 74 & 67 & 52 & 90 & 11691 \\
\hline
\end{tabular}




\begin{tabular}{|c|c|c|c|c|c|c|}
\hline DATE & TEMF & WE & IfF & FiH & Taver & CLIEGHF \\
\hline 71286 & 72 & 69 & 67 & 84 & 79 & 11708 \\
\hline 71286 & 72 & 69 & 68 & 87 & 72 & 11714 \\
\hline 71386 & 73 & 70 & 68 & 84 & 72 & 11722 \\
\hline 71386 & 76 & 72 & 70 & 82 & 74 & 11738 \\
\hline 71386 & 84 & 75 & 71 & 65 & 80 & 11774 \\
\hline 71386 & 88 & 74 & 68 & 52 & 86 & 11825 \\
\hline 71386 & 91 & 78 & 73 & 56 & 89 & 11886 \\
\hline 71386 & 89 & 78 & 73 & 59 & 90 & 11944 \\
\hline 71386 & 75 & 70 & 68 & 79 & 82 & 11970 \\
\hline 71386 & 73 & 71 & 70 & 90 & 74 & 11980 \\
\hline 71486 & 72 & 70 & 69 & 90 & 72 & 11987 \\
\hline 71486 & 75 & 70 & 68 & 79 & $7 \overline{3}$ & 12000 \\
\hline 71186 & 86 & 76 & 71 & 61 & 80 & 12039 \\
\hline 71486 & 90 & 77 & 71 & 54 & 88 & 12096 \\
\hline 71486 & 86 & 75 & 70 & 59 & 88 & 12147 \\
\hline 71486 & 72 & 71 & 70 & 94 & 79 & 12164 \\
\hline 71486 & 72 & 69 & 68 & 87 & 72 & 12170 \\
\hline 71486 & 71 & 70 & 69 & 93 & $7 \overline{1}$ & 12174 \\
\hline 71586 & 71 & 70 & 69 & 93 & 71 & 12177 \\
\hline 71586 & 71 & 70 & 69 & 93 & 71 & 12180 \\
\hline 71586 & 79 & 72 & 69 & 72 & 75 & 12201 \\
\hline 71586 & 85 & 75 & 71 & 63 & 82 & 12241 \\
\hline 71586 & 89 & 77 & 72 & 57 & 87 & 12295 \\
\hline 71586 & 87 & 77 & 73 & 63 & 88 & 12348 \\
\hline 71586 & 78 & 75 & 74 & 88 & 82 & 12378 \\
\hline 71586 & 76 & 75 & 74 & 94 & $7 \overline{7}$ & 12398 \\
\hline 71686 & 74 & 73 & 73 & 97 & 75 & 12411 \\
\hline 71686 & 75 & 74 & 74 & 97 & 74 & 12426 \\
\hline 71686 & 88 & 78 & 74 & 63 & 81 & 12470 \\
\hline 71686 & 90 & 75 & 68 & 48 & 89 & 12528 \\
\hline 71686 & 92 & 75 & 67 & 44 & 91 & 12593 \\
\hline 71686 & 90 & 76. & 69 & 50 & 91 & 12654 \\
\hline 71686 & 85 & 76 & 72 & 65 & 87 & 12703 \\
\hline 71686 & 74 & 74 & $7 \overline{3}$ & 88 & 79 & 12723 \\
\hline 71786 & 76 & 74 & 73 & 91 & 75 & 12740 \\
\hline 71786 & 77 & 76 & 75 & 94 & 76 & 12760 \\
\hline 71786 & 88 & 78 & 74 & 63 & 82 & 12806 \\
\hline 71786 & 90 & 77 & 72 & 56 & 89 & 12864 \\
\hline 71786 & 85 & 76 & 72 & 65 & 87 & 12913 \\
\hline $\begin{array}{l}71786 \\
71786\end{array}$ & 91 & 76 & 69 & 49 & $\begin{array}{l}88 \\
87\end{array}$ & 12972 \\
\hline 71786 & 83 & 77 & 74 & 74 & 87 & 13017 \\
\hline 71786 & 78 & 76 & 75 & 91 & 80 & 13044 \\
\hline 71886 & 75 & 74 & 74 & 97 & 76 & 13062 \\
\hline 71886 & 75 & 74 & 74 & 97 & 75 & 13077 \\
\hline 71886 & 88 & 77. & 73 & 61 & 81 & 13121 \\
\hline 71886 & 96 & 77 & 68 & 40 & 92 & 13193 \\
\hline 71886 & 95 & 76 & 67 & 40 & 95 & 13269 \\
\hline 71886 & 91 & 72 & 63 & 39 & 93 & 13335 \\
\hline 71886 & 86 & 73 & 66 & 51 & 88 & 13386 \\
\hline 71886 & 79 & 74 & 71 & 77 & 82 & 13419 \\
\hline 71986 & 77 & 74 & 72 & 85 & 78 & 13441 \\
\hline 71986 & 76 & 74 & 73 & 91 & 76 & 13460 \\
\hline 71986 & 89 & 78 & 73 & 59 & 82 & 13507 \\
\hline
\end{tabular}




\begin{tabular}{|c|c|c|c|c|c|c|}
\hline DATE & TEMF & WE & [IF & FiH & Taver & CLIIEGHF \\
\hline 71986 & 92 & 76 & 69 & 47 & 90 & 1.3571 \\
\hline 71986 & 96 & 77 & 69 & 42 & 94 & 13646 \\
\hline 71986 & 93 & 76 & 69 & 46 & 94 & 13717 \\
\hline $\begin{array}{l}71986 \\
71986\end{array}$ & $\begin{array}{l}86 \\
80\end{array}$ & $\begin{array}{l}75 \\
75\end{array}$ & $\begin{array}{l}70 \\
72\end{array}$ & $\begin{array}{l}59 \\
77\end{array}$ & $\begin{array}{l}89 \\
83\end{array}$ & $\begin{array}{l}13770 \\
13805\end{array}$ \\
\hline 72086 & 74 & 72 & 71 & 90 & 77 & 13821 \\
\hline 72086 & 75 & 73 & 72 & 90 & 74 & 13836 \\
\hline 72086 & 91 & 76 & 70 & 50 & 83 & 13887 \\
\hline 72086 & 98 & 75 & 64 & 33 & 94 & 13965 \\
\hline 72086 & 99 & 75 & 64 & 32 & 88 & 14052 \\
\hline 72086 & 93 & 79 & 74 & 54 & 96 & 14125 \\
\hline 72086 & 84 & 75 & 71 & 45 & 88 & 14174 \\
\hline 72086 & 79 & 74 & 71 & 77 & 94 & 14205 \\
\hline 72186 & 76 & 72 & 70 & 82 & 77 & 14225 \\
\hline 72186 & 75 & 72 & 70 & 85 & 75 & 14241 \\
\hline 72186 & 84 & 75 & 71 & 65 & 79 & 14276 \\
\hline 72186 & 96 & 74 & 67 & 47 & 87 & 14331 \\
\hline 72186 & 91 & 72 & 63 & 39 & 90 & 14394 \\
\hline 72186 & 87 & 74 & 67 & 52 & .89 & 14448 \\
\hline 72186 & 80 & 69 & 63 & 56 & 83 & 14483 \\
\hline 72186 & 75 & 65 & 59 & 58 & 77 & 14502 \\
\hline 72286 & 73 & 65 & 60 & 64 & 74 & 14512 \\
\hline 72286 & 73 & 66 & 52 & 69 & 73 & 14521 \\
\hline 72286 & 83 & 71 & 64 & 53 & 78 & 14553 \\
\hline 72286 & 88 & 73 & 66 & 48 & 85 & 14603 \\
\hline 72286 & 92 & 71 & 59 & 33 & 90 & 14666 \\
\hline 72286 & 89 & 69 & 57 & 34 & 90 & 14725 \\
\hline 72286 & 81 & 71 & 65 & 58 & 85 & 14764 \\
\hline 72286 & 76 & 69 & 65 & 69 & 78 & 14786 \\
\hline 72386 & 75 & 69 & 66 & 74 & 75 & 14802 \\
\hline $\begin{array}{l}72386 \\
72386\end{array}$ & $\begin{array}{l}74 \\
86\end{array}$ & $\begin{array}{l}70 \\
75\end{array}$ & $\begin{array}{l}68 \\
70\end{array}$ & $\begin{array}{r}82 \\
-0\end{array}$ & $\begin{array}{l}74 \\
80\end{array}$ & $\begin{array}{l}14814 \\
14853\end{array}$ \\
\hline & $\begin{array}{l}80 \\
94\end{array}$ & 73 & 63 & 36 & 90 & $\begin{array}{l}14833 \\
14919\end{array}$ \\
\hline 72386 & 96 & 72 & 59 & 29 & 95 & 14996 \\
\hline 72386 & 91 & 74 & 65 & 42 & 93 & 15063 \\
\hline 72386 & 83 & 72 & 66 & 57 & 87 & 15108 \\
\hline 72386 & 78 & 71 & 68 & 72 & 80 & 15135 \\
\hline 72486 & 76 & 71 & 68 & 76 & 77 & 15155 \\
\hline 72486 & 75 & 71 & 69 & 82 & 75 & 15171 \\
\hline 72486 & 88 & 76 & 71 & 57 & 81 & 15215 \\
\hline 72486 & 96 & 75 & 66 & 37 & 92 & 15287 \\
\hline 72486 & 98 & 76 & 66 & 35 & 97 & 15369 \\
\hline 72486 & 94 & 76 & 68 & 43 & 95 & 15444 \\
\hline 72486 & 87 & 75 & 69 & 55 & 90 & 15501 \\
\hline 72486 & 81 & 73 & 69 & 67 & 84 & 15538 \\
\hline 7086 & 77 & 72 & 70 & 79 & 79 & 15562 \\
\hline 7086 & 79 & 74 & 71 & 77 & 78 & 15588 \\
\hline 7086 & 90 & 78 & 73 & 58 & 84 & 15639 \\
\hline 7086 & 95 & 77 & 59 & 43 & 92 & 15711 \\
\hline 7086 & 99 & 76 & 65 & 33 & 97 & 15795 \\
\hline 7086 & 89 & 76 & 71 & 55 & 94 & 15859 \\
\hline 7086 & 82 & 75 & 72 & 72 & 85 & 15900 \\
\hline 7086 & 80 & 75 & 72 & 77 & 81 & 15932 \\
\hline
\end{tabular}




\begin{tabular}{|c|c|c|c|c|c|c|}
\hline IIATE & TEMF & WB & IIF' & FiH & Taver & CLIIEGHF \\
\hline 72686 & 77 & 74 & 72 & 85 & 78 & 15955 \\
\hline 72686 & 79 & 74 & 71 & 77 & 78 & 15981 \\
\hline 72586 & 87 & 77 & 72 & 61 & 83 & 16026 \\
\hline 72686 & 96 & 78 & 71 & 45 & 91 & 16097 \\
\hline 72686 & 82 & 74 & 71 & 69 & 89 & 16143 \\
\hline 72686 & 84 & 74 & 69 & 61 & 83 & 16184 \\
\hline 72686 & 80 & 73 & 69 & 69 & 82 & 16217 \\
\hline 72686 & 73 & 70 & 68 & 84 & 76 & 16231 \\
\hline 72786 & 71 & 70 & 69 & 93 & 72 & 16236 \\
\hline 72786 & 72 & 70 & 69 & 90 & 71 & 16241 \\
\hline 72786 & 84 & 73 & 68 & 59 & 78 & 16274 \\
\hline 72786 & 89 & 74 & 67 & 48 & 86 & 16327 \\
\hline 72786 & 93 & 74 & 65 & 40 & 91 & 16393 \\
\hline 72786 & 92 & 74 & 65 & 41 & 92 & 16460 \\
\hline 72786 & 84 & 74 & 69 & 61 & 88 & 16508 \\
\hline 72786 & 80 & 74 & 71 & 74 & 82 & 16541 \\
\hline 72886 & 74 & 72 & 71 & 90 & 77 & 16557 \\
\hline 72886 & 76 & 73 & 71 & 85 & 75 & 16574 \\
\hline 72886 & 81 & 75 & 73 & 77 & 78 & 16603 \\
\hline 72886 & 90 & 77 & 72 & 56 & 85 & 16656 \\
\hline 72886 & 97 & 78 & 70 & 42 & 93 & 16732 \\
\hline 72886 & 93 & 80 & 75 & 56 & 95 & 16804 \\
\hline 72886 & 84 & 75 & 71 & 65 & 88 & 16853 \\
\hline 72886 & 79 & 75 & 73 & 82 & 81 & 16884 \\
\hline 72986 & 77 & 74 & 73 & 88 & 78 & 16906 \\
\hline 72986 & 76 & 75 & 74 & 94 & 76 & 16925 \\
\hline 72986 & 86 & 78 & 75 & 70 & 81 & 16965 \\
\hline 72986 & 94 & 77 & 70 & 46 & 90 & 17031 \\
\hline 72986 & 92 & 75 & 68 & 46 & 93 & 17099 \\
\hline 72986 & 91 & 74 & 65 & 42 & 91 & 17163 \\
\hline 72986 & 83 & 71 & 65 & 55 & 87 & 17208 \\
\hline 72986 & 78 & 71 & 67 & 69 & 80 & 17235 \\
\hline 73086 & 75 & 69 & 66 & 74 & 76 & 17253 \\
\hline 73086 & 73 & 68 & 65 & 76 & 74 & 17263 \\
\hline 73086 & 84 & 71 & 64 & 51 & 78 & 17297 \\
\hline 73086 & 92 & 73 & 63 & 38 & 88 & 17357 \\
\hline 73086 & 95 & 73 & 62 & 34 & 93 & 17430 \\
\hline 73086 & 92 & 71 & 59 & 33 & 93 & 17498 \\
\hline 73086 & 82 & 67 & 58 & 44 & 87 & 17541 \\
\hline 73086 & 74 & 67 & 62 & 66 & 78 & 17559 \\
\hline 73186 & 69 & 66 & 64 & 84 & 71 & 17562 \\
\hline 73186 & 72 & 68 & 65 & 79 & 70 & 17565 \\
\hline 73186 & 87 & 74 & 68 & 53 & 79 & 17605 \\
\hline 73186 & 83 & 71 & 65 & 55 & 85 & 17647 \\
\hline 73186 & 91 & 73 & 65 & 42 & 87 & 17704 \\
\hline 73186 & 89 & 76 & 70 & 54 & 90 & 17763 \\
\hline 73186 & 84 & 75 & 71 & 65 & 86 & 17808 \\
\hline 73186 & 77 & 72 & 69 & 76 & 80 & 17835 \\
\hline 8186 & 73 & 70 & 69 & 87 & 75 & 17847 \\
\hline 8186 & 73 & 70 & 68 & 84 & 73 & 17856 \\
\hline 8186 & 83 & 74 & 69 & 63 & 78 & 17887 \\
\hline 8186 & 90 & 74 & 66 & 45 & 86 & 17942 \\
\hline 8186 & 91 & 74 & 66 & 44 & 90 & 18004 \\
\hline
\end{tabular}




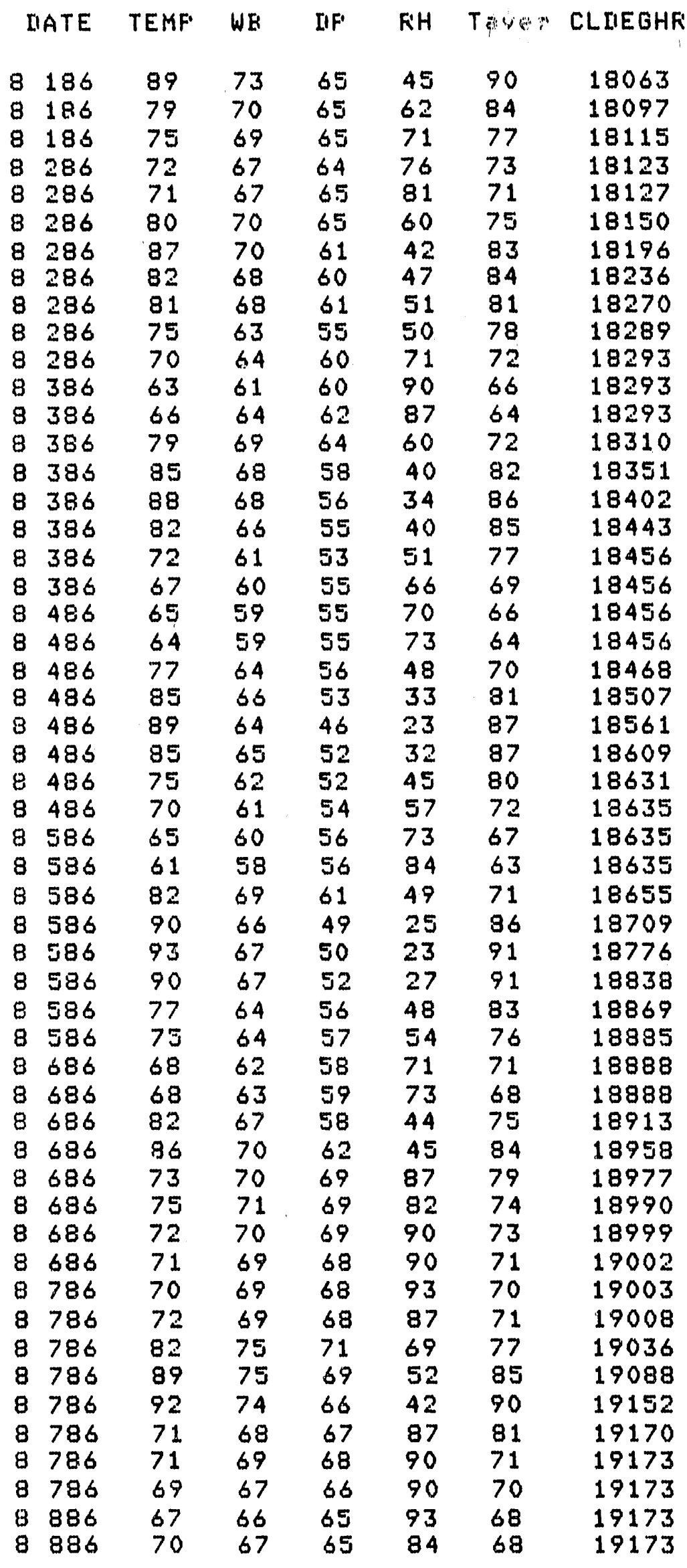




$\begin{array}{lllllll}\text { IIATE } & \text { TEMF } & \text { WE } & \text { IIF } & \text { FHH } & \text { TaVER } & \text { CLIIEGHA } \\ 8886 & 79 & 71 & 67 & 67 & 74 & 19194 \\ 8886 & 85 & 74 & 68 & 57 & 82 & 19234 \\ 8886 & 80 & 71 & 67 & 65 & 82 & 19268 \\ 8886 & 80 & 73 & 69 & 69 & 80 & 19298 \\ 8886 & 77 & 70 & 66 & 69 & 78 & 19321 \\ 88866 & 73 & 68 & 65 & 76 & 75 & 19333 \\ 8986 & 70 & 67 & 66 & 87 & 71 & 19335 \\ 8986 & 71 & 69 & 68 & 90 & 70 & 19338 \\ 8986 & 77 & 72 & 69 & 76 & 74 & 19354 \\ 8986 & 84 & 74 & 69 & 61 & 80 & 19391 \\ 8986 & 87 & 74 & 68 & 53 & 85 & 19440 \\ 8986 & 79 & 72 & 69 & 72 & 83 & 19473 \\ 89986 & 73 & 70 & 69 & 87 & 76 & 19486 \\ 8986 & 70 & 67 & 66 & 87 & 71 & 19488 \\ 81086 & 70 & 67 & 66 & 87 & 70 & 19488 \\ 81086 & 71 & 68 & 67 & 87 & 70 & 19491 \\ 81086 & 81 & 74 & 71 & 72 & 76 & 19516 \\ 81086 & 88 & 75 & 69 & 53 & 84 & 19565 \\ 81086 & 91 & 75 & 68 & 47 & 89 & 19626 \\ 81086 & 76 & 73 & 71 & 85 & 83 & 19655 \\ 81086 & 73 & 71 & 70 & 90 & 74 & 19666 \\ 81086 & 71 & 70 & 69 & 93 & 72 & 19671 \\ 81186 & 72 & 71 & 70 & 94 & 71 & 19676 \\ 81186 & 70 & 69 & 69 & 97 & 71 & 19677 \\ 81186 & 77 & 72 & 69 & 76 & 73 & 19693 \\ 81186 & 83 & 71 & 65 & 55 & 80 & 19728 \\ 81186 & 82 & 69 & 61 & 49 & 82 & 19764 \\ 81186 & 79 & 66 & 58 & 49 & 80 & 19794 \\ 81186 & 71 & 68 & 58 & 64 & 75 & 19803 \\ 81186 & 67 & 62 & 58 & 73 & 69 & 19803 \\ 81286 & 66 & 62 & 59 & 78 & 66 & 19803 \\ 81286 & 64 & 61 & 59 & 84 & 65 & 19803 \\ 81286 & 75 & 67 & 62 & 64 & 69 & 19810 \\ 81286 & 83 & 68 & 59 & 44 & 79 & 19843 \\ 81286 & 82 & 68 & 60 & 47 & 82 & 19880 \\ 81286 & 79 & 68 & 61 & 54 & 80 & 19909 \\ 81286 & 73 & 66 & 61 & 66 & 76 & 19923 \\ 81286 & 68 & 63 & 60 & 76 & 70 & 19923 \\ 81386 & 66 & 62 & 60 & 81 & 67 & 19923 \\ 81386 & 65 & 62 & 60 & 84 & 65 & 19923 \\ 81386 & 75 & 68 & 64 & 69 & 70 & 19931 \\ 81386 & 83 & 74 & 69 & 63 & 79 & 19964 \\ 81386 & 97 & 73 & 66 & 50 & 85 & 20012 \\ 81386 & 84 & 71 & 65 & 53 & 85 & 20056 \\ 81386 & 77 & 72 & 69 & 76 & 80 & 20082 \\ 81386 & 75 & 70 & 68 & 79 & 76 & 20099 \\ 81486 & 72 & 70 & 69 & 90 & 73 & 20107 \\ 81486 & 71 & 69 & 68 & 90 & 71 & 20111 \\ 81486 & 83 & 74 & 70 & 65 & 77 & 20141 \\ 81486 & 88 & 75 & 69 & 53 & 85 & 20191 \\ 81486 & 90 & 74 & 67 & 47 & 89 & 20250 \\ 81486 & 86 & 74 & 68 & 55 & 88 & 20301 \\ 81486 & 78 & 73 & 70 & 77 & 82 & 20331\end{array}$




$\begin{array}{lllllll}\text { IAATE } & \text { TEMF } & \text { WB } & \text { IF } & \text { FH } & \text { TaVer CLIEGHF } \\ 81486 & 73 & 70 & 69 & 87 & 75 & 20343 \\ 81586 & 72 & 68 & 66 & 82 & 72 & 20350 \\ 81586 & 73 & 69 & 67 & 82 & 72 & 20358 \\ 81586 & 85 & 76 & 72 & 65 & 79 & 20394 \\ 81586 & 91 & 76 & 69 & 49 & 88 & 20453 \\ 81586 & 92 & 75 & 68 & 46 & 91 & 20518 \\ 81586 & 88 & 75 & 69 & 53 & 90 & 20575 \\ 81586 & 80 & 74 & 71 & 74 & 84 & 20611 \\ 81586 & 75 & 72 & 71 & 87 & 77 & 20830 \\ 81686 & 73 & 70 & 69 & 97 & 74 & 20640 \\ 81686 & 74 & 71 & 70 & 87 & 73 & 20652 \\ 81686 & 77 & 79 & 67 & 71 & 75 & 20670 \\ 81686 & 71 & 70 & 70 & 97 & 74 & 20678 \\ 81686 & 73 & 72 & 71 & 94 & 72 & 20685 \\ 81686 & 77 & 72 & 71 & 94 & 73 & 20694 \\ 81686 & 73 & 72 & 71 & 94 & 73 & 20703 \\ 81686 & 71 & 70 & 70 & 97 & 72 & 20708 \\ 81786 & 71 & 70 & 70 & 97 & 71 & 20711 \\ 81786 & 72 & 71 & 71 & 97 & 71 & 20716 \\ 81786 & 75 & 73 & 72 & 90 & 73 & 20729 \\ 81786 & 81 & 75 & 72 & 74 & 78 & 20757 \\ 81786 & 85 & 75 & 70 & 61 & 83 & 20799 \\ 81786 & 82 & 74 & 70 & 67 & 83 & 20838 \\ 81786 & 76 & 71 & 69 & 79 & 79 & 20860 \\ 81786 & 73 & 70 & 69 & 87 & 74 & 20871 \\ 81886 & 71 & 69 & 68 & 90 & 72 & 20876 \\ 81886 & 71 & 69 & 68 & 90 & 71 & 20879 \\ 81886 & 80 & 74 & 71 & 74 & 75 & 20902 \\ 81886 & 86 & 75 & 70 & 59 & 83 & 20946 \\ 81886 & 87 & 74 & 68 & 53 & 86 & 20996 \\ 81886 & 83 & 73 & 68 & 61 & 85 & 21038 \\ 81886 & 77 & 71 & 68 & 74 & 80 & 21063 \\ 81886 & 72 & 68 & 66 & 82 & 74 & 21073 \\ 81986 & 70 & 67 & 67 & 87 & 71 & 21075 \\ 81986 & 69 & 67 & 67 & 90 & 69 & 21075 \\ 81986 & 79 & 71 & 71 & 67 & 74 & 21094 \\ 81986 & 86 & 72 & 72 & 50 & 82 & 21137 \\ 81986 & 87 & 71 & 71 & 43 & 86 & 21187 \\ 81986 & 82 & 70 & 70 & 53 & 84 & 21227 \\ 81986 & 75 & 69 & 69 & 74 & 78 & 21247 \\ 81986 & 71 & 67 & 67 & 81 & 73 & 21253 \\ 82086 & 68 & 66 & 64 & 87 & 69 & 21253 \\ 82086 & 66 & 64 & 63 & 90 & 67 & 21253 \\ 82086 & 76 & 70 & 66 & 71 & 71 & 21264 \\ 82086 & 84 & 73 & 67 & 57 & 80 & 21300 \\ 82086 & 85 & 72 & 65 & 51 & 84 & 21344 \\ 82086 & 81 & 71 & 65 & 58 & 83 & 21380 \\ 82086 & 76 & 70 & 67 & 74 & 78 & 21402 \\ 82086 & 74 & 69 & 67 & 79 & 75 & 21415 \\ 82186 & 72 & 69 & 67 & 84 & 73 & 21423 \\ 82186 & 70 & 68 & 67 & 90 & 71 & 21424 \\ 82186 & 79 & 72 & 69 & 72 & 74 & 21444 \\ 82186 & 86 & 76 & 71 & 61 & 82 & 21487\end{array}$




$\begin{array}{lllllll}\text { IIATE } & \text { TEMF } & \text { WB } & \text { DF } & \text { FH } & \text { T JVET } & \text { CLIIEGHF } \\ 82186 & 86 & 74 & 68 & 55 & 86 & 21535 \\ 82186 & 82 & 74 & 70 & 67 & 84 & 21574 \\ 82186 & 78 & 72 & 69 & 74 & 80 & 21601 \\ 82186 & 76 & 72 & 70 & 82 & 77 & 21621 \\ 82286 & 73 & 71 & 70 & 90 & 74 & 21632 \\ 82286 & 73 & 71 & 70 & 90 & 73 & 21641 \\ 82286 & 84 & 75 & 71 & 65 & 78 & 21675 \\ 82286 & 87 & 75 & 69 & 55 & 85 & 21723 \\ 82286 & 86 & 76 & 71 & 61 & 86 & 21772 \\ 82286 & 85 & 75 & 71 & 63 & 85 & 21818 \\ 82286 & 77 & 74 & 72 & 85 & 81 & 21845 \\ 82286 & 74 & 71 & 70 & 87 & 75 & 21859 \\ 82386 & 74 & 71 & 69 & 85 & 74 & 21871 \\ 82386 & 73 & 70 & 69 & 87 & 73 & 21881 \\ 82386 & 81 & 74 & 71 & 72 & 77 & 21908 \\ 82386 & 86 & 76 & 71 & 61 & 83 & 21952 \\ 82386 & 90 & 76 & 69 & 50 & 88 & 22009 \\ 82386 & 85 & 74 & 68 & 57 & 87 & 22058 \\ 82386 & 80 & 72 & 68 & 67 & 82 & 22092 \\ 82386 & 77 & 71 & 68 & 74 & 78 & 22115 \\ 82486 & 76 & 71 & 69 & 79 & 76 & 22134 \\ 82486 & 73 & 70 & 69 & 87 & 74 & 22145 \\ 82486 & 76 & 72 & 70 & 82 & 74 & 22161 \\ 82486 & 81 & 72 & 68 & 65 & 78 & 22190 \\ 82486 & 83 & 73 & 68 & 61 & 82 & 22227 \\ 82486 & 81 & 68 & 60 & 49 & 82 & 22262 \\ 82486 & 73 & 63 & 57 & 57 & 77 & 22277 \\ 82486 & 68 & 62 & 57 & 68 & 70 & 22278 \\ 8086 & 66 & 63 & 61 & 84 & 67 & 22278 \\ 8086 & 65 & 63 & 61 & 87 & 65 & 22278 \\ 8086 & 80 & 70 & 65 & 60 & 72 & 22296 \\ 8086 & 87 & 72 & 65 & 48 & 83 & 22342 \\ 8086 & 91 & 73 & 64 & 41 & 89 & 22402 \\ 8886 & 85 & 72 & 66 & 53 & 88 & 22452 \\ 8086 & 77 & 72 & 69 & 76 & 81 & 22479 \\ 8086 & 75 & 71 & 69 & 82 & 76 & 22495 \\ 82686 & 72 & 69 & 68 & 87 & 73 & 22503 \\ 82686 & 72 & 69 & 68 & 87 & 72 & 22509 \\ 82686 & 84 & 76 & 72 & 67 & 78 & 22542 \\ 82686 & 91 & 78 & 73 & 56 & 87 & 22600 \\ 82686 & 85 & 76 & 72 & 65 & 88 & 22650 \\ 82686 & 76 & 73 & 72 & 88 & 80 & 22674 \\ 82686 & 76 & 73 & 72 & 88 & 76 & 22692 \\ 82686 & 76 & 73 & 71 & 85 & 76 & 22710 \\ 82786 & 74 & 70 & 68 & 82 & 75 & 22724 \\ 82786 & 72 & 69 & 68 & 87 & 73 & 22731 \\ 82786 & 80 & 74 & 71 & 74 & 76 & 22755 \\ 82786 & 88 & 76 & 71 & 57 & 84 & 22803 \\ 82786 & 86 & 73 & 67 & 55 & 87 & 22853 \\ 82786 & 72 & 67 & 64 & 76 & 75 & 22893 \\ 82886 & 69 & 65 & 63 & 81 & 70 & 22894 \\ 88 & 68 & 64 & 81 & 68 & 22894\end{array}$




$\begin{array}{lllllll}\text { IIATE } & \text { TEMF } & \text { WE } & \text { IIF } & \text { FH } & \text { TaVer } & \text { CLIEGHF } \\ 82886 & 64 & 64 & 59 & 75 & 66 & 22894 \\ 82886 & 64 & 64 & 57 & 63 & 64 & 22894 \\ 82886 & 71 & 71 & 55 & 34 & 67 & 22896 \\ 82886 & 72 & 72 & 55 & 32 & 71 & 22901 \\ 82886 & 67 & 67 & 54 & 40 & 69 & 22901 \\ 82886 & 59 & 59 & 50 & 52 & 63 & 22901 \\ 82886 & 54 & 54 & 47 & 59 & 56 & 22901 \\ 82986 & 51 & 46 & 40 & 66 & 52 & 22901 \\ 82986 & 52 & 47 & 41 & 66 & 51 & 22901 \\ 82986 & 65 & 54 & 44 & 47 & 58 & 22901 \\ 82986 & 73 & 57 & 44 & 36 & 69 & 22905 \\ 82986 & 77 & 59 & 45 & 32 & 75 & 22923 \\ 82986 & 73 & 56 & 41 & 32 & 75 & 22935 \\ 82986 & 64 & 55 & 47 & 54 & 68 & 22935 \\ 82986 & 64 & 54 & 46 & 52 & 64 & 22935 \\ 83086 & 62 & 57 & 52 & 67 & 63 & 22935 \\ 83086 & 63 & 58 & 54 & 64 & 62 & 22935 \\ 83086 & 71 & 60 & 52 & 66 & 67 & 22937 \\ 83086 & 76 & 63 & 54 & 67 & 73 & 22951 \\ 83086 & 78 & 63 & 52 & 67 & 77 & 22974 \\ 83086 & 75 & 63 & 55 & 66 & 76 & 22991 \\ 83086 & 68 & 62 & 58 & 65 & 71 & 22993 \\ 83086 & 68 & 62 & 57 & 66 & 68 & 22993 \\ 83186 & 67 & 62 & 59 & 76 & 67 & 22993 \\ 83186 & 64 & 62 & 61 & 90 & 65 & 22993 \\ 83186 & 66 & 64 & 62 & 87 & 65 & 22993 \\ 83186 & 67 & 65 & 64 & 90 & 66 & 22993 \\ 83186 & 67 & 66 & 65 & 93 & 6 \% & 22993 \\ 83186 & 66 & 65 & 64 & 93 & 66 & 22993 \\ 83186 & 65 & 64 & 64 & 97 & 65 & 22993 \\ 83186 & 66 & 65 & 64 & 93 & 65 & 22993\end{array}$



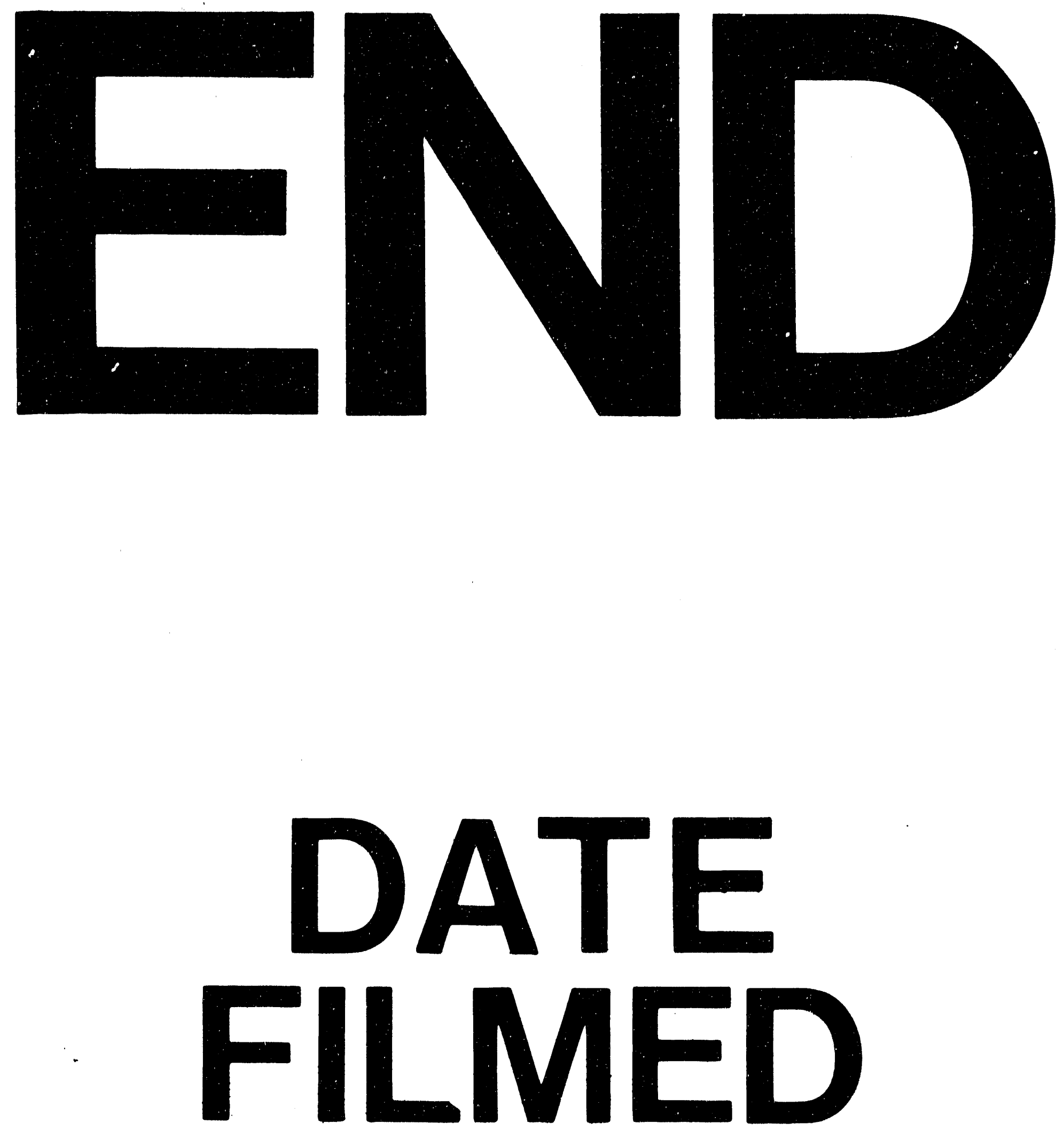

I

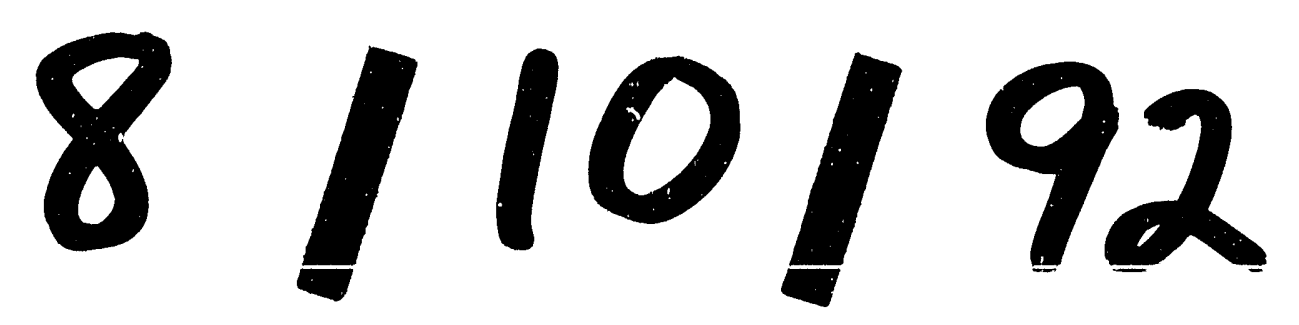


